\author{
UNIVERSIDADE DE SÃO PAULO \\ INSTITUTO DE QUÍMICA DE SÃO CARLOS
}

Grupo de Materiais Macromoleculares e Fibras Lignocelulósicas

\title{
HIDRÓLISE DE POLPA DE SISAL COMO VIA DE PRODUC̣ÃO DE ETANOL E MATERIAIS
}

Talita Martins Lacerda

São Carlos

2012 





\section{HIDRÓLISE DE POLPA DE SISAL COMO VIA DE PRODUC̣ÃO DE ETANOL E MATERIAIS}

Tese apresentada ao Instituto de Química de São Carlos, da Universidade de São Paulo, como parte dos requisitos para a obtenção do título de Doutor em Química.

Área de concentração: Físico-Química

Orientadora: Profa. Dra. Elisabete Frollini

São Carlos

2012 
Ficha Catalográfica elaborada pela Seção de Referência e Atendimento ao Usuário do SBI/IQSC

Lacerda, Talita Martins

Hidrólise de polpa de sisal como via de produção de etanol e materiais. / Talita Martins Lacerda. -- São Carlos, IQSC, 2012. $252 \mathrm{p}$.

Tese (Doutorado) - Instituto de Química de São Carlos / Universidade de São Paulo, 2012.

Orientadora: Profa. Dra. Elisabete Frollini.

1. Celulose. 2. Bioetanol. 3. Hidrólise. I. Título.

\section{Referências Bibliográficas conferidas pelo $S B$ BIIQSC}


Zlos meus amados pais, Xário e Cássia, e irmã Daniela, pelo constante incentivo e carinho. 



Acima de tudo, agradeço a Deus pela minha vida, pela oportunidade de trabalhar em algo que me dá muito prazer, entre pessoas com quem aprendo muito, e principalmente por me iluminar e me dar forças nas ocasiões em que mais preciso. A Ele minha eterna gratidão.

A todos aqueles que, direta ou indiretamente, contribuíram para a realização deste trabalho, assim como para o meu crescimento acadêmico e pessoal, gostaria de expressar aqui os meus sinceros agradecimentos:

Aos meus pais, Mário e Cássia, pela imensa dedicação durante todos os dias de minha vida. Por sempre me apoiarem e ficarem ao meu lado, por todos os ensinamentos que me tornaram a pessoa que sou hoje, pela paciência e amor infinitos. À minha irmã Daniela, simplesmente por estar presente na minha vida, me ajudando a superar cada desafio que surge, e ao meu cunhado-irmão Thiago, por me ensinar que [quase] todos os problemas se resolvem com uma boa risada. Amo vocês do fundo do meu coração e tenho muitíssimo orgulho da família que tenho.

À minha orientadora, Profa. Dra. Elisabete Frollini, pela excelente orientação desde minha iniciação científica, pela disponibilidade constante e pelo entusiasmo demonstrado ao longo destes anos. Por tudo o que me ensinou, por acreditar e confiar em mim e nas minhas capacidades, muito obrigada!

À minha orientadora no doutorado sanduíche, Profa. Dra. Véronique Coma, por me receber em seu grupo, e a todos os que estavam presentes durante o período em que trabalhei no laboratório US2B da Universidade de Bordeaux I, pela ótima convivência.

Ao Prof. Dr. Paulo Sérgio Campana Filho, pelos ensinamentos e amizade.

Aos amigos Márcia Dib Zambon e Luís Antônio Ramos, técnicos do grupo de Físico-Química Orgânica, pelo profissionalismo e pelas ótimas conversas. À Márcia, tenho ainda que agradecer o apoio frente às dificuldades e imprevistos [muitos!] ocorridos durante as análises de cromatografia. Muito obrigada pela sua ajuda, amizade e paciência!

Aos meus amigos do Grupo de Materiais Macromoleculares e Fibras Lignocelulósicas, e do Grupo de Físico-química Orgânica: Dani, Bruno, Rachel, Fernando, Elaine, Bibi, Fran, Cris, Aline, Nádia, Jorge, Tonimar, Érika, Anderson, Virgínia, Daniella, Lilian, Adriana e Leandro [espero não ter esquecido ninguém!], que se tornaram uma 
extensão da minha família. Nestes anos pudemos dividir bancadas, estufas, vidrarias e muitas alegrias. 0 alto astral de cada um de vocês foi fundamental para tornar minha caminhada até aqui muito mais feliz!

Aos técnicos José Augusto Lopes da Rocha [IFSC] pela eficiência na obtenção dos dados de raios X, e Márcio de Paula [IQSC] pelas análises de Microscopia Eletrônica de Varredura.

Aos técnicos da oficina mecânica, Ednelson de Almeida, Antônio Donizeti Javitório e Milton Aparecido Sevilha, e da oficina eletrônica, Élvio Caetano, por todas as vezes em que dedicaram parte do seu tempo para me ajudar nas situações em que precisei [urgentemente] do trabalho de vocês.

A todos os meus amigos, em especial à minha comadre Gisela, que independentemente da cidade, país ou continente em que se encontram hoje, me acolheram e acompanharam durante todo ou parte deste percurso, um "muito obrigada" repleto de carinho por estarem presentes, por proporcionarem momentos únicos de alegria, por me ouvirem e apoiarem sempre. Também agradeço a todos os membros da Pastoral de Rua, em especial à minha amiga Rita, por me ensinarem a cada manhã de sábado a importância de dedicar parte de nossas vidas àqueles que são esquecidos pela sociedade. Amo vocês!

Ao meu cachorrinho Hélio, pela companhia durante as infinitas horas de redação desta tese.

Desejo ainda expressar o meu agradecimento à Universidade de São Paulo e ao Instituto de Química de São Carlos, a todos os membros do Departamento de Físico-química [DFQ] que, de alguma forma, contribuíram para a realização deste trabalho, e à Capes pelo apoio financeiro através da concessão das bolsas de doutorado e doutorado sanduíche.

\section{Al todos, Mnito Obrigada!}


palavras-chave

resumo
Polpa de sisal; hidrólise ácida; hidrólise enzimática; bioetanol; micro e nanofibras; filmes de quitosana/celulose.

A possível escassez dos recursos fósseis, juntamente com o aumento imprevisível dos respectivos preços, levou, nas últimas décadas, a um aumento considerável de iniciativas dedicadas não só à procura de fontes alternativas de produtos químicos e polímeros a partir de fontes renováveis, mas também de fontes alternativas de energia - em particular a biomassa vegetal. $O$ estudo desenvolvido no presente trabalho está inserido neste contexto. A despolimerização de celulose de sisal pode ocorrer via hidrólise, ácida ou enzimática, podendo resultar nos açúcares fermentescíveis necessários para a produção do chamado etanol celulósico e, em etapas intermediárias do processo, em micro e nanopartículas, que podem atuar como reforço de matriz polimérica baseada, por exemplo, em quitosana. 0 estudo aqui relatado está relacionado à análise do material celulósico não reagido durante a hidrólise, e do licor que contém principalmente glicose. As reações de hidrólise ácida e enzimática de polpa de sisal [constituída de celulose e hemicelulose] foram exploradas. Uma importante característica que envolve a hidrólise ácida de biomassa é a possibilidade de utilização de diversos ácidos, pois a princípio, necessita-se apenas de uma fonte de prótons no meio aquoso para que a reação ocorra. Neste contexto, em uma primeira etapa, uma série de reações de hidrólise ácida de polpa de sisal, previamente tratada com solução alcalina (mercerizada) ou não, foi feita com ácido sulfúrico $\left[0,9-4,6 \mathrm{molL}^{-1}, 100^{\circ} \mathrm{C}\right.$, 6h de reação]. Em uma segunda etapa, o ácido sulfúrico foi substituído por ácido oxálico, e os tempos de reação foram maiores [18h] que aqueles considerados para o ácido sulfúrico, tendo em vista o menor valor do $\mathrm{pK}_{a}$ do ácido oxálico. Reações de hidrólise enzimática foram realizadas com o uso de um complexo enzimático comercial [Accellerase 1500 - Genencor], e dois diferentes pré-tratamentos, ambos visando à eliminação de hemiceluloses, foram avaliados, sendo: mercerização e tratamento com solução de ácido oxálico 0,9 moll ${ }^{-1}$. Para acompanhar os processos, em determinados intervalos de tempo, foram retiradas alíquotas do meio reacional, sendo que os licores foram analisados por cromatografia líquida de alta eficiência [CLAE], a fim de avaliar a natureza e o teor dos produtos da hidrólise. As polpas residuais (não hidrolisadas], suspensas no 
licor, foram avaliadas por microscopia eletrônica de varredura, massa molar média por viscosimetria capilar, índice de cristalinidade por difração de raios $X$ e tamanhos médios das fibras a partir de um analisador de fibras (MorFi - analisador de tamanho médio de fibras por imagem], e espalhamento de luz [FOQELS]. Para todas as reações de hidrólise ácida estudadas, as massas molares médias das polpas residuais diminuíram até dez vezes logo nos primeiros minutos de reação e os valores de índice de cristalinidade mostraram que as regiões não cristalinas da celulose são primeiramente hidrolisadas, sendo as regiões cristalinas uma grande barreira frente à hidrólise. Os resultados mostraram que o aumento da concentração do catalisador ácido elevou consideravelmente a porcentagem de hidrólise, principalmente no caso do ácido oxálico que, quando usado na concentração de 0,9 molL $^{-1}$, não foi capaz de hidrolisar com eficiência as cadeias de celulose, mas apenas eliminou as hemiceluloses presentes na polpa, motivo que levou à sua aplicação como agente de pré-tratamento para a polpa frente à hidrólise enzimática. Os rendimentos das reações mostraram que o ácido sulfúrico chega a ser aproximadamente 25\% mais eficiente que o ácido oxálico em termos de produção de glicose. Entretanto, o ácido oxálico possui a grande vantagem de ser proveniente de fontes renováveis e, se usado nas concentrações adequadas, pode ser uma excelente opção como pré-tratamento da polpa de celulose para as reações de hidrólise. Os resultados de hidrólise enzimática mostraram que a polpa que passou pelo pré-tratamento da mercerização foi mais eficiente como material de partida do que aquela tratada com ácido oxálico, já que a primeira levou a concentrações de glicose até 2,5 vezes maiores, nas mesmas condições de concentração de enzima, temperatura e tempo de reação. As reações de hidrólise ácida e enzimática de material lignocelulósico são de grande importância no que diz respeito à produção de etanol de segunda geração e micro/nanofibras que podem ser incorporadas em materiais. Filmes de matriz de quitosana foram produzidos com a inserção de fibras de celulose sem tratamento, mercerizada, e residuais das reações de hidrólise ácida e enzimática, em diferentes concentrações [2,5, 7,5 e 15\% em massa]. Os filmes foram submetidos à solicitação de tração, e a morfologia foi acessada por microscopia eletrônica de varredura de emissão de campo [FEGMEV]. Os resultados mostraram que, no geral, o filme de quitosana [69 MPa], assim como os baseados em quitosana/celulose [75 $\mathrm{MPa}$ ), apresentam resistência à tração superior ou no mesmo patamar de filmes similares descritos na literatura. Este trabalho forneceu resultados promissores e está largamente inserido no interesse atual de utilização de materiais provenientes de fontes renováveis preferencialmente àqueles de fontes fósseis. 
keywords

\author{
abstract
}

Sisal pulp; acid hydrolysis; enzymatic hydrolysis; bioethanol; micro and nanofibers; chitosan/cellulose films.

The possible shortage of crude oil and the unpredictable increase in its prices have led to an impressive expansion of initiatives in the last decades dedicated not only to the search of alternative sources of chemicals and polymers, but also to suppliers of energy, both from vegetal biomass. The depolymerization of sisal cellulose may occur via acid or enzymatic hydrolysis, resulting in the fermentable sugars used in the production of the so-called cellulosic ethanol and also at the intermediate steps of the process, in micro and nanoparticles that may act as reinforcement in polymeric matrices, including those derived from cellulose. The study here reported is related to the analysis of the unreacted cellulosic material and to the liquor containing mainly glucose, from acid and enzymatic hydrolysis of sisal pulp formed by cellulose and hemicellulose. An important characteristic that involves the acid hydrolysis of biomass is the possibility of utilization of different acids, since only a source of protons in the media is required for the reaction to occur, in principle. In this context, a series of reactions of acid hydrolysis of sisal pulp was carried out under varying concentrations of sulfuric acid, from 0,9 to $4,6 \mathrm{molL}^{-1}$, at $100^{\circ} \mathrm{C}$ as a first step. In a second step, the acid catalyst was replaced by oxalic acid, and the reaction lengths were bigger than those considered for sulfuric acid due to the lower value of $\mathrm{pK}_{\text {a }}$ of oxalic acid. The reactions of enzymatic hydrolysis were carried out with a commercial enzymatic complex [Accellerase 1500 - Genencor], and two different pretreatments, both aiming at the elimination of hemicelluloses, were essayed as follows: mercerization and treatment with oxalic acid 0,9 $\mathrm{moll}^{-1}$. To follow the processes of acid and enzymatic hydrolysis in determined time intervals, aliquots were withdrawn from the reaction media so as to be analyzed by High Performance Liquid Chromatography [HPLC] aiming at the evaluation of the nature and content of the hydrolysis products. The unreacted cellulose suspended in the liquor was characterized by Scanning Electron Microscopy, capillary viscometry, $\mathrm{X}$ ray diffraction, and average size of fibers by using a fiber analyzer and light scattering. For all acid hydrolysis reactions studied, the average molar mass of the unreacted cellulose decreased up to ten times in the first minutes of reaction, and the 
values of crystallinity index showed that the non-crystalline regions of cellulose are firstly hydrolyzed, and the crystalline regions act as barriers to the hydrolysis. The results of HPLC showed that an increase in concentration considerably increases the yield of hydrolysis, mainly in the case of oxalic acid as a catalyst, which was not able to hydrolyze the chains of cellulose when in low concentrations $\left[0,9 \mathrm{molL}^{-1}\right]$. It only eliminated the hemicellulose present in the pulp, reason why this acid was used as a pretreatment agent in enzymatic hydrolysis at this concentration. The reaction yields showed that the sulfuric acid can be up to $25 \%$ more efficient than the oxalic acid in terms of glucose production. However, the oxalic acid has the great advantage of possibly being produced from natural resources as well as being an excellent choice as a pretreatment agent for the lignocellulosic biomass to be used in hydrolysis reactions if used in the adequate concentrations. The results of enzymatic hydrolysis showed that the mercerized pulp was more efficient as raw material than the one treated with oxalic acid, as the first led to higher glucose content at the same conditions of concentration, temperature and time of reaction. The reactions of acid and enzymatic hydrolysis of lignocellulosic materials are of great importance to the production of second generation ethanol and micro and nanofibers, which may be incorporated into biocomposites. Films of chitosan matrix were prepared with the addition of cellulose fibers (untreated, mercerized and residual from the acid and enzymatic hydrolysis reactions] under various concentrations [2,5, 7,5 e 15\% wt\%]. The films were subjected to traction analysis and its morphology was accessed by field emission scanning electron microscopy [SEM-FEG]. The results showed that, in general, chitosan films [69 MPa], just like films based on chitosan-cellulose [75 $\mathrm{MPa}$ ] presented tensile strength values that are superior or the same as similar films described in literature. Therefore, the study here reported produced promising results and is widely inserted in the current interest of utilization of materials from renewable resources instead of those from fossil resources. 


\section{LISTA de SigLAS E SímBOLOS}

HMF 5-hidroximetil-2-furfuraldeído

CLAE Cromatografia líquida de alta eficiência

MM $M_{\text {vis }}$ Massa molar média viscosimétrica

GP Grau de polimerização

Cuen Etilenodiamina cúprica

I. Índice de cristalinidade

FOQELS Fiber-Optic Quasi-Electric Light Scattering

$\mathbf{E}_{\mathrm{a}}$ Energia de ativação 


\section{LISTA DE FIGURAS}

Figura 1 - CONVERSÃO ENZIMÁtICA DA SACAROSE A GLICOSE E FRUTOSE...........................................28

FIgURA 2 - MolÉCULAS DE B-D-GLICOPIRANOSE E PIRANO. ............................................................ 38

FIGURA 3 - ESTRUTURA MOLECULAR DA CELULOSE ................................................................................ 39

FIgURA 4 - REPRESENTAC̣ÃO ESQUEMÁTICA DAS LIGAC̣ÕES HIDROGÊNIO PRESENTES NA UNIDADE REPETITIVA DA CELULOSE [CELOBIOSE].................................................................................. 39

FIGURA 5 - REPRESENTAC̣ÃO ESQUEMÁTICA DAS LIGAC̣̃̃ES HIDROGÊNIO PRESENTES ENTRE AS CADEIAS DE CELULOSE. ........................................................................................................... 40

Figura 6 - PROJeC̣õeS dAS CELAS UNITÁRIAS dA CELULOSE I E CELULOSE II ........................................ 43

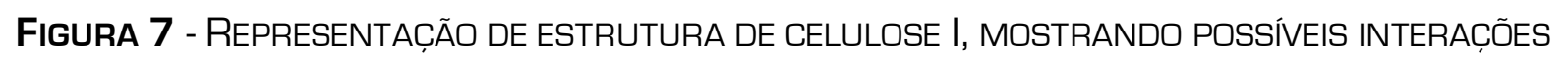
DOS İONS SÓDIO NAS LIGAC̣̃̃ES HIDROGÊNIO INTER- E INTRAMOLECULARES ................................... 47

FigURA 8 - ALGUMAS DISTÂNCIAS REFERENTES AO ARRANJO DOS ÁTOMOS NO PLANO PARA CELULOSE I [NATIVA] E CELULOSE II [MERCERIZADA] ………………………............................... 48

Figura 9 - MeCANISMOS de HIDRÓLISE bÁSICA dA CELULOSE.......................................................... 49

Figura 10 - (A) COMPOSIIC̣ÃO DAS HeMICELULOSES PRESENTES NO SISAL E (B) ESTRUTURAS QUÍMICAS DE UNIDADES DE AÇÚCARES PRESENTES NA HEMICELULOSE. ......................................... 50

FIGURA 11 - ÁlCOOIS PRECURSORES FUNDAMENTAIS PARA A FORMAC̣ÃO DA LIGNINA .....................51

FIGURA 12 - ESQUEMA REPRESENTATIVO DA ASSOCIAC̣̃̃O ENTRE AS ESTRUTURAS DE CELULOSE, HEMICELULOSE E LIGNINA ......................................................................................................... 52

FIGURA 13 - PLANTA DE SISAL .......................................................................................................... 53

Figura 14 - Produção de SISAL No Brasil e No Mundo de 2000 a 2009, DE ACORDO COM A FAO 
FIGURA 15 - DIAGRAMA DE BLOCO DO PROCESSO DE UMA BIORREFINARIA LIGNOCELULÓSICA INTEGRADA

FIgURA 16 - MECANISMO dE HIDRÓLISE ÁCIDA dAS LIGAC̣ÕES GLICOSÍDICAS. HIDROGÊNIOS E GRUPOS HIDROXILA FORAM OMITIDOS

FIgURA 17 - EVOLUC̣ÃO DOS CUSTOS DOS COMPLEXOS ENZIMÁTICOS [CELULASES] AO LONGO DOS ANOS [DEAN ET AL., 2006].

FIGURA 18 - REPRESENTAC̣ÃO ESQUEMÁTICA DA CONVERSÃO DE CELULOSE A GLICOSE POR UM MECANISMO DE HIDRÓLISE ENZIMÁTICA...... 76

Figura 19 - REPRESENTAC̣ÃO ESQUEMÁTICA DA LEI DE BRAGG.............................................................. 85

FigurA 20 - DifRATOGRAMA TíPICO DE POLPA DE CELULOSE DE SISAL (SEM TRATAMENTO PRÉVIO]...... 86

FIGURA 21 - DIFRATOGRAMAS DE RAIOS X CORRESPONDENTES ÀS CELULOSES I E II................................. 86

FIGURA 22 - ANALISADOR DE FIBRAS [MORFI COMPACT - TECHPAP] ...................................................... 88

FiguRA 23 - REATOR ENCAMISADO “A”; BANHO TERMOSTATIZADO “B”; ROTOR DE AGITACÃO MECÂNICA "C"; CONDENSADOR “D”; SISTEMA PARA RETIRADA DE ALÍQUOTAS “E”.

Figura 24 - Micrografias dA POLPA DE CELULOSE dE SISAL NÃO TRATADA (A) E MERCERIZADA [B].98

FIGURA 25 - MAPAS DE DENSIDADE REFERENTES À DISTRIBUIC̣ÃO DE COMPRIMENTO E ESPESSURA DAS FIBRAS CONTIDAS NA POLPA DE SISAL NÃO TRATADA [A] E MERCERIZADA [B] 99

FIgURA 26 - VALORES DE [A] MASSA MOLAR MÉDIA VISCOSIMÉTRICA E [B] ÍNDICE DE CRISTALINIDADE, OBTIDOS A PARTIR DA ANÁLISE DAS POLPAS RESIDUAIS DAS REAC̣ÕES DE HIDRÓLISE PARTINDO DE POLPA SEM TRATAMENTO. 102

FIGURA 27 - DIMENSÃO DO PLANO OO2 DAS POLPAS RESIDUAIS [NÃO MERCERIZADAS] EM FUNÇ̃̃O DO TEMPO DA REAC̣ÃO DE HIDRÓLISE [CONCENTRAC̣ÃO DE ÁCIDO ENTRE 0,9 E 4,6 MOLL"1, 100ㄷ).

FIGURA 28 - MICROGRAFIAS DAS POLPAS RESIDUAIS DAS REAC̣ÕES DE HIDRÓLISE COM POLPA SEM TRATAMENTO, $100^{\circ} \mathrm{C}$, COM DIFERENTES CONCENTRAÇÕES DE ÁCIDO SULFÚRICO, SENDO: [A]

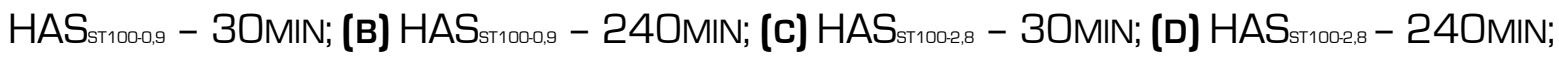
[E] HAS sт100-4,6 $_{-}$30MIN; [F] HAS FIGURA 29 - REAC̣ÃO DE DESIDRATAC̣ÃO DE GLICOSE EM MEIO ÁCIDO …………........................................ 106 FIGURA 30 - REAC̣ÃO DE DESIDRATAC̣ÃO DE XILOSE EM MEIO ÁCIDO ........................................................... 107

FIgURA 31 - [A] REAC̣ÕES dE DECOMPOSIC̣ÃO DE GLICOSE E XILOSE; [в] FORMAC̣ÃO DE POLIFURFURAL EM MEIO ÁCIDO. 107

FIGURA 32 - CONCENTRAC̣ÃO DE GLICOSE EM FUNC̣ÃO DO TEMPO PARA AS REAC̣ÕES COM DIFERENTES CONCENTRAC̣ÕES DE ÁCIDO $\left[100^{\circ} \mathrm{C}\right]$...... 
FIGURA 33 - CONCENTRAC̣ÃO DE GLICOSE POTENCIAL EM FUNC̣ÃO DO TEMPO DE HIDRÓLISE E DA CONCENTRAC̣ÃO DE ÁCIDO.

FIGURA 34 - CONCENTRAC̣ÃO DE HMF NO LICOR EM FUNC̣ÃO DO TEMPO DE HIDRÓLISE E DA CONCENTRAC̣ÃO DE ÁCIDO.

FIGURA 35 - CONCENTRAC̣ÃO DE ÁCIDO FÓRMICO NO LICOR EM FUNCCÃO DO TEMPO DE HIDRÓLISE E DA CONCENTRAC̣ÃO DE ÁCIDO.

FIGURA 36 - CONCENTRAC̣ÃO DE XILOSE NO LICOR EM FUNC̣ÃO DO TEMPO DE HIDRÓLISE E DA CONCENTRAC̣ÃO DE ÁCIDO $\left(100^{\circ} \mathrm{C}\right)$.

FIGURA 37 - CONCENTRAC̣ÃO DE FURFURAL NO LICOR EM FUNC̣ÃO DO TEMPO DE HIDRÓLISE E DA CONCENTRAC̣ÃO DE ÁCIDO $\left(100^{\circ} \mathrm{C}\right)$.

FiguRA 38 - VALORES DE [A] MASSA MOLAR MÉDIA VISCOSIMÉTRICA E [B] ÍNDICE DE CRISTALINIDADE DAS POLPAS RESIDUAIS DAS REAC̣ÕES DE HIDRÓLISE PARTINDO DE POLPA MERCERIZADA.

FIGURA 39 - DIMENSÃO DO PLANO 002 DAS POLPAS RESIDUAIS MERCERIZADAS, EM FUNCCÃO DO TEMPO DE HIDRÓLISE $\left[100^{\circ} \mathrm{C}, 0,9\right.$ - 4,6 $\left.\mathrm{MOLL}^{-1} \mathrm{H}_{2} \mathrm{SO}_{4}\right]$.

FIgURA 40 - MiCROGRAFIAS DAS POLPAS RESIDUAIS DAS REAC̣ÕES DE HIDRÓLISE REALIZADAS A 100C, COM DIFERENTES CONCENTRAÇÕES DE ÁCIDO SULFÚRICO, SENDO: [A] HAS

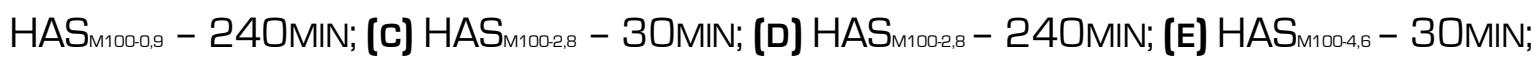
[F] HAS $\mathrm{H}_{1004,6}-240 \mathrm{MIN}$ 121

FIGURA 41 - MAPAS DE DENSIDADE REFERENTES ÀS POLPAS RESIDUAIS DAS REAÇÕES DE HIDRÓLISE COM POLPA MERCERIZADA APÓS, RESPECTIVAMENTE, 3 E 6H, SENDO [A,B] REAC̣ÃO HAS

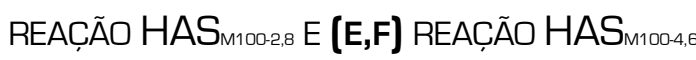
123

FIGURA 42 - DISTRIBUIC̣ÃO MÉDIA DOS TAMANHOS DE PARTíCULAS DETECTADAS POR ESPALHAMENTO DE LUZ. 124

FIGURA 43 - CONCENTRAC̣ÃO DE GLICOSE EM FUNC̣ÃO DO TEMPO PARA AS REAÇÕES COM DIFERENTES CONCENTRAÇÕES DE ÁCIDO $\left[100^{\circ} \mathrm{C}\right]$. 126

FIGURA 44 - CONCENTRAC̣ÃO DE GLICOSE POTENCIAL EM FUNCCÃO DO TEMPO DE HIDRÓLISE E DA CONCENTRAC̣ÃO DE ÁCIDO.

FIGURA 45 - CONCENTRAC̣ÃO DE HMF NO LICOR EM FUNC̣ÃO DO TEMPO DE HIDRÓLISE. 128

FIGURA 46 - CONCENTRAC̣ÃO DE ÁCIDO FÓRMICO NO LICOR EM FUNC̣ÃO DO TEMPO DE HIDRÓLISE. .... 129

FIGURA 47 - CONCENTRAC̣ÃO DE XILOSE NO LICOR EM FUNC̣ÃO DO TEMPO DE HIDRÓLISE. 130

FIGURA 48 - CONCENTRAC̣ÃO DE ARABINOSE NO LICOR EM FUNC̣ÃO DO TEMPO DE HIDRÓLISE. 131

FIGURA 49 - CONCENTRAC̣ÃO DE FURFURAL NO LICOR EM FUNC̣ÃO DO TEMPO DE HIDRÓLISE. 132 
FiguRA 50 - AJUSTE NÃO-LINEAR DO MODELO DE SAEMAN PARA HIDRÓLISE ÁCIDA DE CELULOSE A $100^{\circ} \mathrm{C}$, COM DIFERENTES CONCENTRAÇÕES DE ÁCIDO, SENDO (A) 0,9 $\mathrm{MOLL}^{-1}$, (B) 1,8 $\mathrm{MOLL}^{-1}$, (C) 2,8 $\mathrm{MOLL}^{-1}$, [D] 3,7 $\mathrm{MOLL}^{-1} \mathrm{E}$ [E] 4,6 $\mathrm{MOLL}^{-1}$

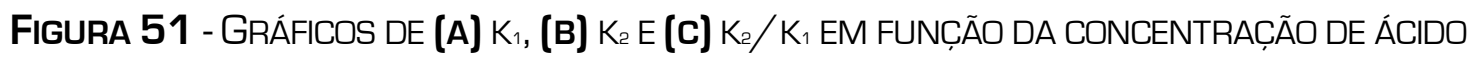
SULFÚRICO UTILIZADA.

FIgURA 52 - MiCROGRAFIAS DAS POLPAS DE PARTIDA, MERCERIZADAS E SEPARADAS POR

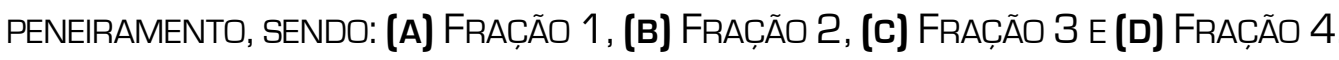
138

FIgURA 53 - VALORES DE [A] MASSA MOLAR MÉDIA VISCOSIMÉTRICA E [B] ÍNDICE DE CRISTALINIDADE DAS CELULOSES RESIDUAIS DAS REAÇÕES DE HIDRÓLISE PARTINDO DE POLPA MERCERIZADA FRACIONADA.

FIGURA 54 - DIMENSÃO DO PLANO OO2 DAS POLPAS RESIDUAIS DAS REAÇÕES PARTINDO DE POLPA MERCERIZADA FRACIONADA, EM FUNC̣̃̃O DO TEMPO DE REAC̣ÃO $\left[100^{\circ} \mathrm{C}, 4,6 \mathrm{MOLL}^{-1} \mathrm{H}_{2} \mathrm{SO}_{4}\right]$... 140

FIGURA 55 - MICROGRAFIAS DAS POLPAS RESIDUAIS, APÓS 240 MIN, REFERENTES ÀS REAC̣ÕES

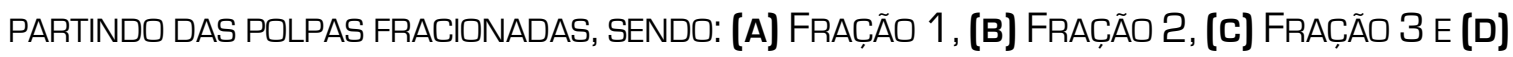
FRAC̣ÃO 4

FiguRA 56 - MAPAS de dENSIDADE dAS POLPAS INICIAIS (FRAC̣ÃO 1 - A; FRAC̣ÃO 4 - B] E RESIDUAIS [NÃO HIDROLISADAS] DAS REAC̣ÕES REALIZADAS A PARTIR DA FRAÇÃO 1, APÓS 180 MIN [C] E 360 MIN [E], E A PARTIR DA FRAÇÃO 4, APÓS 180 MIN [D] E 360 MIN [E] 143

FiguRA 57 - CONCENTRAC̣ÃO dE GLICOSE [A] E XILOSE [B] EM FUNĈ̣̃O DO TEMPO DE REAC̣ÃO, COM A VARIAC̣ÃO DO TAMANHO MÉDIO DAS FIBRAS $\left[4,6 \mathrm{MOLL}^{-1} \mathrm{H}_{2} \mathrm{SO}_{4}, 100^{\circ} \mathrm{C}\right]$ 146

FIGURA 58 - CONCENTRAC̣ÃO DE GLICOSE NO LICOR EM FUNC̣ÃO DO TEMPO DE HIDRÓLISE: 60-100ㄷ, 4,6 $\mathrm{MOLL}^{-1} \mathrm{H}_{2} \mathrm{SO}_{4}$ 148

FIGURA 59 - AJUSTE NÃO LINEAR DO MODELO DE SAEMAN PARA HIDRÓLISE ÁCIDA DE CELULOSE [4,6 MOLL ${ }^{-1} \mathrm{H}_{2} \mathrm{SO}_{4}, 60-100^{\circ} \mathrm{C}$ ]. 150

FIGURA 60 - GRÁFICO dE ARREHNIUS PARA HIDRÓLISE ÁCIDA DE CELULOSE DE SISAL [60 - 100 E 4,6 $\mathrm{MOLL}^{-1} \mathrm{DE} \mathrm{H}_{2} \mathrm{SO}_{4}$ ]. 151

FIgURA 61 - VALORES DE MASSA MOLAR MÉDIA VISCOSIMÉTRICA OBTIDOS A PARTIR DA ANÁLISE DAS POLPAS RESIDUAIS DAS REAC̣ÕES DE HIDRÓLISE COM CELULOSE (A] SEM TRATAMENTOE [B] MERCERIZADA [TEMPERATURAS ENTRE 80 E $100^{\circ} \mathrm{C}, 4,6 \mathrm{MOLL}^{-1}[\mathrm{COOH}]_{2}$ ]......

FiguRA 62 - ÍNDICE DE CRISTALINIDADE DAS CELULOSES RESIDUAIS DAS REAC̣ÕES [A] HAO COM ÁCIDO OXÁLICO 4,6 MOLL-1 , EM FUNC̣ÃO DO TEMPO.

FIGURA 63 - DIMENSÃO DO PLANO OO2 DAS POLPAS RESIDUAIS EM FUNC̣ÃO DO TEMPO DE REAC̣ÃO [A] PARTINDO DE POLPA SEM TRATAMENTO E $[\mathrm{COOH}]_{2} 0,9 \mathrm{MOLL}^{-1}, 100^{\circ} \mathrm{C}$ E [B] PARTINDO DE POLPA MERCERIZADA E $[\mathrm{COOH}]_{2} 4,6 \mathrm{MOLL}^{-1}, 80-100^{\circ} \mathrm{C}$ 158 


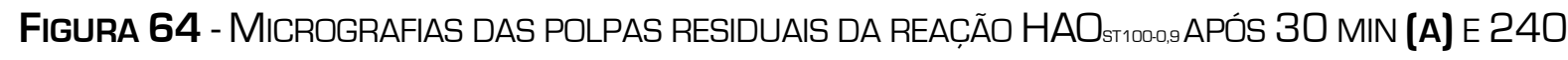
MIN [B]

FIGURA 65 - MicROGRAFIA DAS POLPAS RESIDUAIS DAS REAÇÕES HAO ${ }_{\text {мво } 4,6}$ [A,B], HAO ${ }_{\text {мв5 } 4,6}$ [C,D],

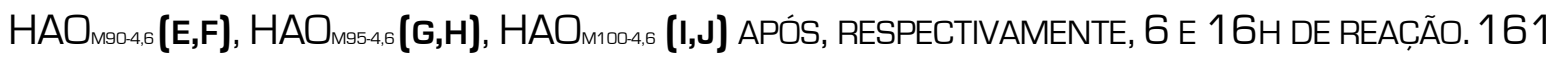

FIGURA 66 - MAPAS DE DENSIDADE REFERENTES ÀS CELULOSES RESIDUAIS DAS REAC̣ÕES DE HIDRÓLISE COM 4,6 MOLL ${ }^{-1}$ DE ÁCIDO OXÁLICO E VARIAÇÃO DE TEMPERATURA, SENDO: $(\mathbf{A}, \mathbf{B}) 80^{\circ} \mathrm{C},[\mathbf{C}, \mathbf{D}]$ $85^{\circ} \mathrm{C},[\mathrm{E}, \mathrm{F}] 90^{\circ} \mathrm{C},[\mathrm{G}, \mathrm{H}] 9^{\circ} \mathrm{C},[\mathrm{I}, \mathrm{J}] 100^{\circ} \mathrm{C}$, PARA TEMPOS IGUAIS A $6 \mathrm{HE} 16 \mathrm{H}$, RESPECTIVAMENTE. 163

FIGURA 67 - DISTRIBUIC̣ÃO MÉDIA DOS TAMANHOS DE PARTíCULAS DETECTADAS POR ESPALHAMENTO DE LUZ. 165

FIGURA 68 - CONCENTRAC̣ÃO DE XILOSE EM FUNC̣ÃO DO TEMPO PARA A REAC̣ÃO HAO 167

FIGURA 69 - CONCENTRAC̣ÃO DE GLICOSE ENCONTRADA NO LICOR PARA AS REAC̣ÕES REALIZADAS COM 4,6 MOLL-1 DE ÁCIDO OXÁLICO [80-100 C]. 168

FIGURA 70 - CONCENTRAC̣ÃO DE GLICOSE POTENCIAL CALCULADA PARA AS REAC̣ÕES REALIZADAS COM 4,6 $\mathrm{MOLL}^{-1}[\mathrm{COOH}]_{2}\left[80-100^{\circ} \mathrm{C}\right]$. 169

FIGURA 71 - CONCENTRAC̣ÃO DE HMF NO LICOR EM FUNC̣ÃO DO TEMPO DE HIDRÓLISE. 170

FIGURA 72 - CONCENTRAC̣ÃO DE ÁCIDO FÓRMICO NO LICOR EM FUNC̣ÃO DO TEMPO DE HIDRÓLISE. .... 170

FIGURA 73 - CONCENTRAC̣ÃO DE XILOSE NO LICOR EM FUNC̣ÃO DO TEMPO DE HIDRÓLISE. 171

FIGURA 74 - CONCENTRAC̣ÃO DE FURFURAL NO LICOR EM FUNC̣ÃO DO TEMPO DE HIDRÓLISE. 172

FIgURA 75 - AJUSTE NÃO-LINEAR DO MODELO DE SAEMAN PARA REAÇÕES DE HIDRÓLISE ÁCIDA DE CELULOSE COM ÁCIDO OXÁLICO 4,6 MOLL-1 E CELULOSE MERCERIZADA $\left[T=80-100^{\circ} \mathrm{C}\right]$. 173

FIgURA 76 - GRÁFICO dE ARREHNIUS PARA HIDRÓLISE ÁCIDA DE CELULOSE DE SISAL [80 - 100 C E 4,6 $\left.\mathrm{MOLL}^{-1}[\mathrm{COOH}]_{2}\right]$. 175

FIgURA 77 - MiCROGRAFIAS DAS FIBRAS DE CELULOSE DE SISAL MERCERIZADA [A] E TRATADA COM ÁCIDO OXÁLICO 0,9 MOLL-1' [B]. 180

FIGURA 78 - VALORES DE MASSA MOLAR MÉDIA VISCOSIMÉTRICA DAS POLPAS RESIDUAIS DAS REAC̣ÕES DE HIDRÓLISE ENZIMÁTICA PARTINDO DE [A] POLPA MERCERIZADA E [B] POLPA TRATADA COM ÁCIDO OXÁLICO 0,9 MOLL

FIGURA 79 - VALORES DE ÍNDICE DE CRISTALINIDADE DAS POLPAS RESIDUAIS DAS REAC̣ÕES DE HIDRÓLISE ENZIMÁTICA PARTINDO DE [A] POLPA MERCERIZADA E [B] POLPA TRATADA COM ÁCIDO OXÁLICO 0,9 MOLL ${ }^{-1}$ 184

FIGURA 80 - DIMENSÃO DO PLANO OO2 DAS POLPAS RESIDUAIS EM FUNC̣ÃO DO TEMPO DA REAC̣ÃO DE HIDRÓLISE ENZIMATICA PARTIDO DE [A] POLPA MERCERIZADA E [B] POLPA TRATADA COM ÁCIDO OXÁLICO $\left[T=50^{\circ} \mathrm{C}\right]$. 
FIGURA 81 - MICROGRAFIAS DAS POLPAS RESIDUAIS DAS REAC̣ÕES DE HIDRÓLISE ENZIMÁTICA, A PARTIR

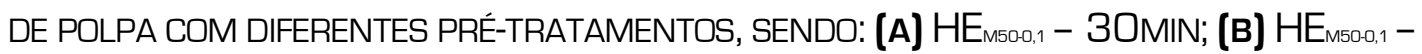

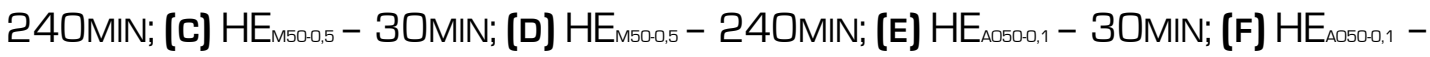

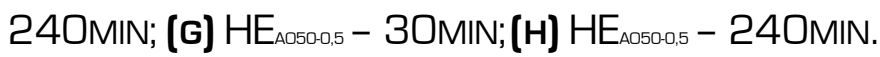

FIGURA 82 - CONCENTRAC̣ÃO DE GLICOSE NO LICOR PROVENIENTE DAS REAC̣ÕES DE HIDRÓLISE ENZIMÁTICA, EM TODAS AS CONDIC̣ÕES AVALIADAS.

FiguRA 83 - CONCENTRAC̣ÃO DE XILOSE NO LICOR PROVENIENTE DAS REAC̣ÕES DE HIDRÓLISE ENZIMÁTICA QUE PARTIRAM DE POLPA TRATADA COM ÁCIDO OXÁLICO. 191

FIGURA 84 - ESTRUTURA QUÍMICA DA QUITINA [GA>1-GA] E DA QUITOSANA [1-GA>>GA] [ADAPTADO DE: FERNANDES ET AL., 2011]. 200

FIgURA 85 - PROPRIEDADES MECÂNICAS SOB TRAÇÃO DOS FILMES OBTIDOS. ERROS VARIANDO ENTRE (A) 0,20 E 8,40\%, (B] 0,10 e 14,40\% E [C] 0,70 E 12,20\%. 215

FIGURA 86 - MICROGRAFIAS DO CORTE TRANSVERSAL DOS FILMES (A) Q100, (B) QPST2,5, [C] QPM2,5, (D) QNC2,5, [E] QHE2,5, (F) QPST7,5, [G] QPM7,5, (H) QNC7,5, (I) QHE7,5, [ J] QPST15, (K) QPM15, (L) QNC15 E [M] QHE15 ............................................................... 221

FIGURA 87 - MICROGRAFIA DOS NANOCRISTAIS DE CELULOSE OBTIDOS POR HIDRÓLISE ÁCIDA. ..........2२૩ FIGURA 88 - MICROGRAFIA DAS NANOESTRUTURAS DE CELULOSE OBTIDAS POR HIDRÓLISE ENZIMÁTICA. .223 


\section{LISTA DE TABELAS}

TABela 1 - MASSA MOLAR MÉdIA VISCOSIMÉTRICA, TEOR DE CELULOSE E HEMICELULOSES E ÍNDICE DE CRISTALINIDADE DAS POLPAS CELULÓSICAS.

TABELA 2 - CódigOS USADOS PARA DENOMINAR AS REAC̣ÕES ESTUDADAS [100], DE ACORDO COM AS CONDIC̣ÕES DE CONCENTRAC̣ÃO DO ÁCIDO.

TABela 3 - NATUREZA dOS POSSÍVEIS AC̣úCARES E DERIVADOS QUE PODEM SER ENCONTRADOS NOS LICORES OBTIDOS NAS REAC̣ÕES DE HIDRÓLISE DE POLPA CELULÓSICA. 108

TABELA 4 - CódigOS USADOS PARA DENOMINAR AS REAÇÕES ESTUDADAS (100], DE ACORDO COM AS CONDIC̣ÕES DE CONCENTRAC̣ÃO DO ÁCIDO.

TABela 5 - NATUREZA dOS POSSÍvels AC̣úCARES E DERIVADOS QUE PODEM SER ENCONTRADOS NOS LICORES OBTIDOS NAS REAC̣ÕES DE HIDRÓLISE DE POLPA CELULÓSICA.

TABELA 6 - CONSTANTES DE HIDRÓLISE DE CELULOSE [ $K_{1}$ ], DECOMPOSIC̣ÃO DE GLICOSE [Ke] E VALOR DE $\mathrm{R}^{2}$ 134

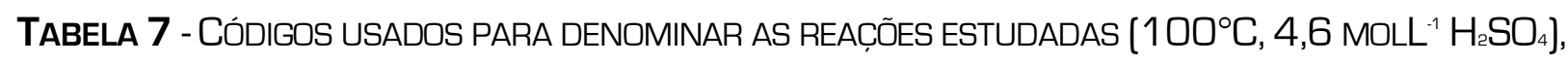
DE ACORDO COM AS CONDIC̣ÕES DE FRACIONAMENTO E CRISTALINIDADE DA POLPA DE PARTIDA.. 137

TABELA 8 - VALORES DE ÍNDICE DE CRISTALINIDADE E COMPRIMENTO E ESPESSURA MÉDIOS DAS DIFERENTES FRAÇÕES DE POLPAS DE PARTIDA USADAS, E O RESPECTIVO VALOR MÁXIMO DE CONCENTRAC̣ÃO DE XILOSE E GLICOSE OBTIDOS A PARTIR DELAS.

TABELA 9 - CONSTANTES DE HIDRÓLISE DE CELULOSE [ $K_{1}$ ], DECOMPOSIC̣ÃO DE GLICOSE [Ke] E VALOR DE $R^{2}$ 150

TABELA 10 - CódigOS usADOS PARA DENOMINAR AS REAC̣ÕES ESTUDADAS, DE ACORDO COM AS CONDIC̣ÕES DE CONCENTRAC̣ÃO DE ÁCIDO, TEMPERATURA E TEMPO DE REAC̣ÃO. 
TABELA 11 - NATUREZA DOS POSSÍVEIS AÇÚCARES E DERIVADOS QUE PODEM SER ENCONTRADOS NOS LICORES OBTIDOS NAS REAC̣ÕES DE HIDRÓLISE DE POLPA CELULÓSICA...............................................166

TABELA 12 - CoNSTANTES DE HIDRÓLISE DE CELULOSE [ $K_{1}$ ], DECOMPOSIC̣ÃO DE GLICOSE [Ke] E VALOR DE $R^{2}$.

TABela 13 - Valores de glicose máxima, glicose potencial e poRCentagem de Celulose

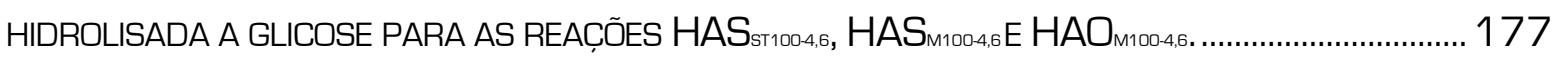

TABela 14 - Códigos USADOS PARA DENOMINAR AS REAC̣̃̃ES ESTUDADAS (50ㄷ) DE ACORDO COM AS CONDIC̄̃̃ES EMPREGADAS. 179

TABela 15 - CódigOS USADOS PARA DENOMINAR OS FILMES DE QUITOSANA/CELULOSE, E SUAS RESPECTIVAS PORCENTAGENS [EM MASSA]. 213 


\section{SUMÁRIO}

Resumo

Abstract

Lista de Siglas e Símbolos...........................................................................................

Lista de Figuras...........................................................................................................

Lista de Tabelas..........................................................................................................................

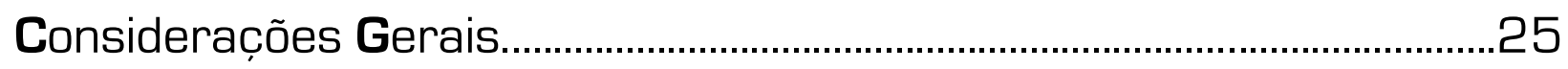

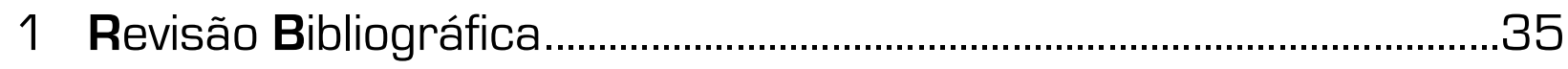

1.1 Fibras Lignócelulósicas - Fibras Vegetais ………………………………………………...... 35

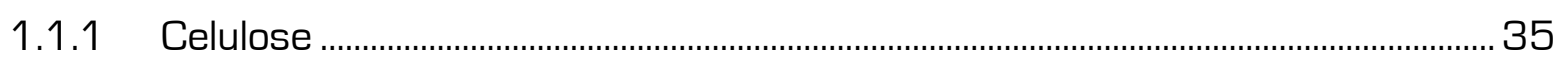

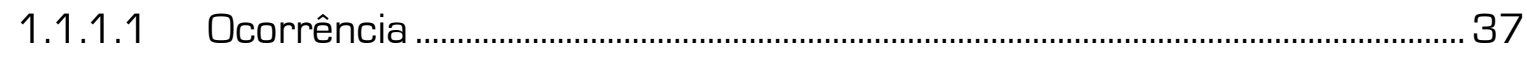

1.1.1.2 A estrutura molecular.............................................................................................

1.1.1.3 A estrutura supramolecular .................................................................................39

1.1.1.4 Cristalinidade e polimorfismo da celulose .......................................................... 41

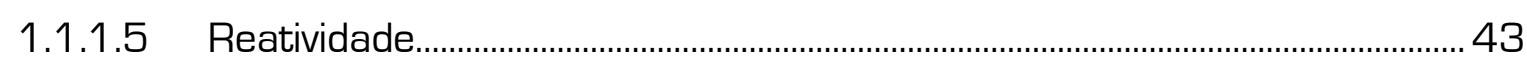

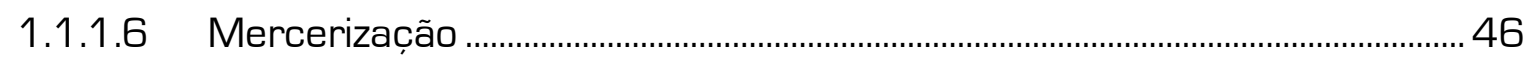




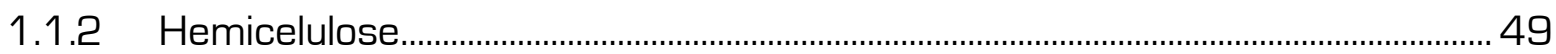

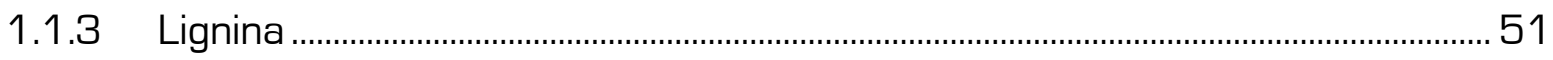

1.2 O sisal.................................................................................................................................

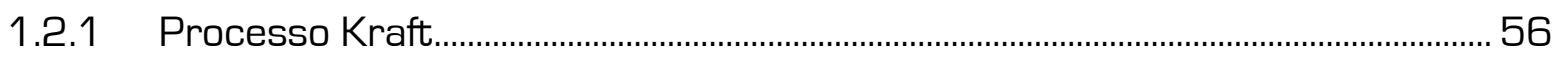

1.3 Conceito de Biorrefinaria .................................................................................................... 58

2 Hidrólise de polpa de sisal: Estudo da sacarificação de celulose

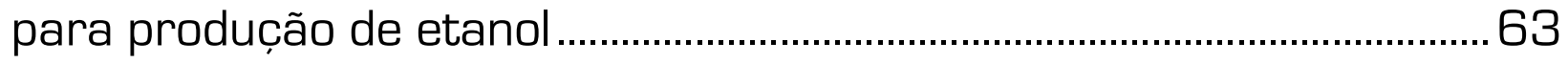

2.1 Introdução ................................................................................................................................ 63

2.1.1 Sacarificação da celulose ................................................................................................. 63

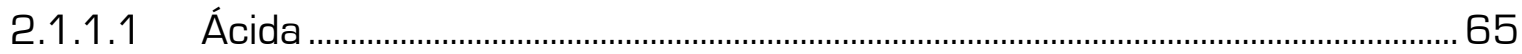

2.1.1.2 Enzimática ......................................................................................................................

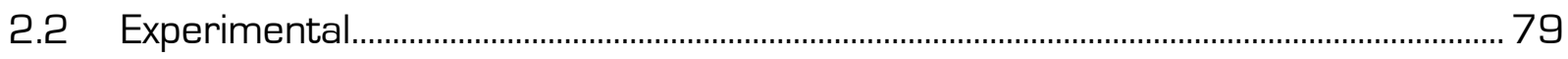

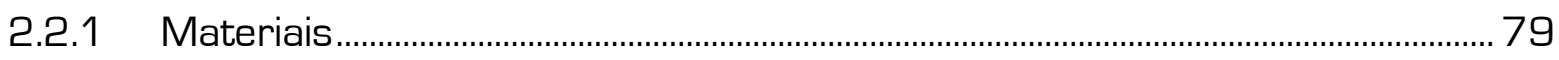

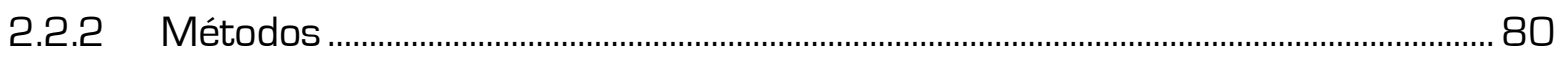

2.2.2.1 Caracterização da polpa de partida........................................................................ 80

2.2.2.2 Mercerização ................................................................................................................90

2.2.2.3 Hidrólise Ácida ............................................................................................................90

2.2.2.4 Hidrólise Enzimática....................................................................................................94

2.3 Resultados e Discussão ………………………………………………………………………...96

2.3.1 Caracterização da polpa de partida..............................................................................97

2.3.2 Reações de hidrólise ácida, com ácido sulfúrico como catalisador ................ 100

2.3.2.1 Caracterização da polpa residual ........................................................................ 102

2.3.2.2 Caracterização dos produtos gerados nas reações de hidrólise ........... 106

2.3.2.3 Caracterização da polpa residual ......................................................................... 117

2.3.2.4 Caracterização dos produtos gerados nas reações de hidrólise ........... 125

2.3.2.5 Caracterização da polpa residual ...................................................................... 138 
2.3.2.6 Caracterização dos produtos gerados nas reações de hidrólise

2.3.3 Reações de hidrólise ácida, com ácido oxálico como catalisador 153

2.3.3.1 Caracterização da polpa residual...................................................................... 154

2.3.3.2 Caracterização dos produtos gerados nas reações de hidrólise............. 165

2.3.4 Rendimentos da hidrólise ácida de polpa de sisal .............................................. 176

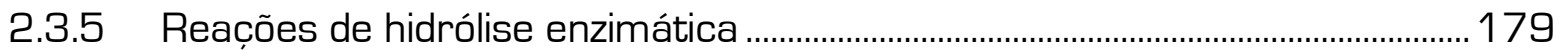

2.3.5.1 Caracterização da polpa residual..................................................................... 181

2.3.5.2 Caracterização dos produtos gerados nas reações de hidrólise............. 188

2.3.6 Rendimentos da hidrólise enzimática de polpa de sisal....................................... 192

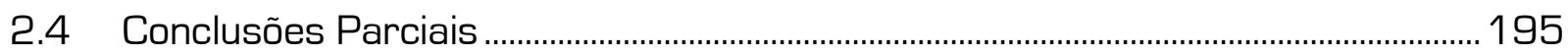

3 Hidrólise de polpa de sisal: Aplicação na obtenção de filmes "bio-

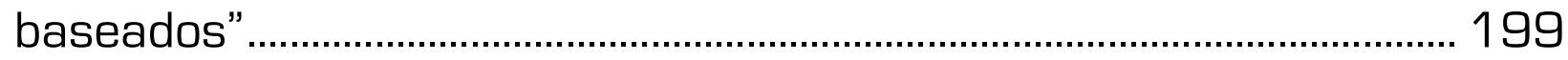

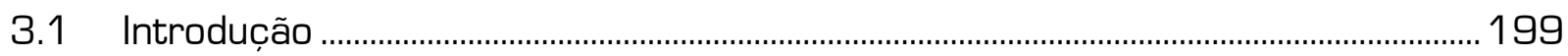

3.2 Filmes de celulose e quitosana .....................................................................................

3.2.1 Hidrólise ácida de polpa celulósica para a produção de nanocristais............204

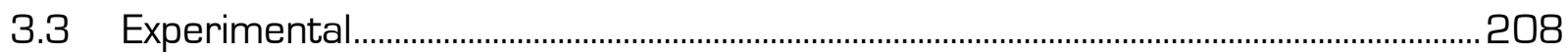

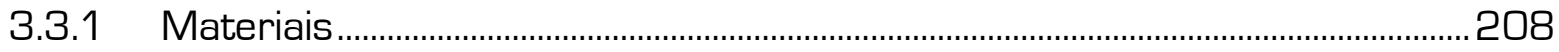

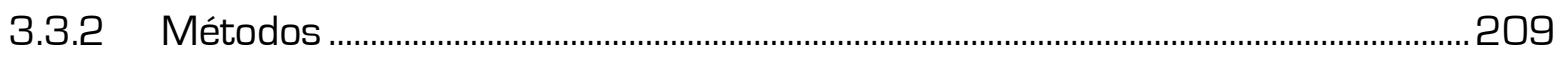

3.3.2.1 Preparação de filmes de quitosana .....................................................................209

3.3.2.2 Hidrólise ácida de polpa celulósica para obtenção de nanocristais.......209

3.3.2.3 Hidrólise enzimática de polpa celulósica para a obtenção de micro e nanofibras.......

3.3.2.4 Preparação de filmes de quitosana associados a

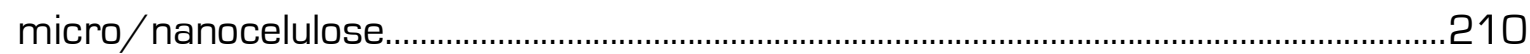

3.3.2.5 Caracterização dos filmes de quitosana/celulose.........................................211

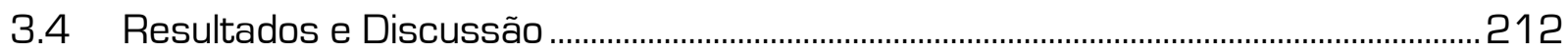

3.4.1 Caracterização dos filmes …………................................................................... 214 
3.4.1.1 Ensaios mecânicos de tração 214

3.4.1.2 Avaliação morfológica ...............................................................................218

3.5 Conclusões Parciais ..................................................................................................... 224

4 Conclusões Gerais ........................................................................

5 Anexos

6 Referências Bibliográficas .................................................................... 233 


\section{CONSIDERAC̣ÕES GERAIS}

\section{BIOMASSA LIGNOCELULÓSICA}

Do ponto de vista da geração de energia, o termo biomassa abrange os derivados de organismos vivos, gerados em curto intervalo de tempo, utilizados como combustiveis ou para a sua produção. Tal definição exclui os combustíveis fósseis que, mesmo tendo sido derivados de matéria orgânica vegetal e animal, necessitaram de milhões de anos para sua conversão na forma que são encontrados atualmente [HIGMAN e VAN DER BURGT, 2003]. Do ponto de vista da ecologia, biomassa é a quantidade total de matéria viva existente num ecossistema ou numa população animal ou vegetal. Os dois conceitos estão, portanto, interligados, embora sejam diferentes (MAMEDES, RODRIGUES e VANISSANG, 2010). Com exceção de algumas microalgas e matérias com altos índices de umidade, a biomassa se caracteriza, essencialmente, por se tratar de matéria carbonada no estado sólido.

De maneira mais específica, a biomassa lignoce/ulósica é aquela originada principalmente de atividades agrícolas, sendo considerada a maior e mais abundante 
fonte de carboidratos do planeta. A composição da biomassa lignocelulósica consiste basicamente de três macromoléculas: celulose, hemiceluloses e lignina [BALAT, BALAT e ÖZ, 2008). Pequenas proporções de proteínas, lipídeos [gorduras, ceras, óleos] e cinzas podem também estar presentes [DING e HIMMEL, 2006; ZHANG e LYND, 2004; FENGEL e WEGENER, 1984].

\section{BIOMASSA COMO FONTE DE ENERGIA}

Uma das primeiras utilizações da biomassa pelo homem para a obtenção de energia foi o uso do fogo. A madeira foi por muito tempo a principal fonte energética utilizada pelo homem, ao lado de óleos vegetais e animais, em menor escala. A Revolução Industrial marcou o auge da importância do consumo da biomassa, com o uso de lenha na indústria siderúrgica, além de sua aplicação nos transportes [HAMILTON, 2008].

Alguns empreendimentos brasileiros que marcaram o uso da biomassa ocorreram no setor de transportes. Dos anos de 1920 até os primeiros anos da década seguinte, período da crise decorrente da Primeira Guerra Mundial, compostos de álcool, éter etílico e óleo de mamona foram produzidos como substitutos da gasolina, com relativo sucesso. O programa Proálcool, implantado na década de 70, marcou a opção do álcool combustível como alternativa ao uso da gasolina. Apesar dos problemas enfrentados, principalmente nos anos 90, o uso do álcool sobrevive atualmente, em especial com o surgimento dos carros fabricados motores bicombustível. A gasolina comercializada no Brasil atualmente consiste em uma mistura contendo aproximadamente $25 \%$ de álcool e a tecnologia de produção de veículos a álcool atinge níveis de excelência?.

\footnotetext{
1 Disponível em: http:/ / www.biodieselbr.com
} 
Além disso, a experiência nacional não se limita ao setor de transportes.

setor de energia elétrica tem sido beneficiado com a energia gerada em usinas de álcool e açúcar, a partir da queima de bagaço e palha da cana-de-açúcar. Outros resíduos, como palha de arroz ou serragem de madeira, alimentam algumas termoelétricas. 0 vinhoto, resíduo do caldo de cana, retirado na fase de decantação, antes despejado nos rios, vem sendo agora reaproveitado como adubo em algumas propriedades. Na siderurgia, experiências anteriores mostraram ser possível a utilização do carvão vegetal de madeira plantada para a produção do aço [RATTER, RIBEIRO e BRIDGEWATER, 1997; BRITO, 1990; BLAU, 1978], ou seja, a implementação de florestas energéticas sustentáveis, tema que gerou um projeto intitulado "Florestas energéticas na matriz de agroenergia brasileira", desenvolvido pela Embrapa Florestas ${ }^{2}$.

As crises de abastecimento de petróleo tornaram importante a utilização de derivados da biomassa, como álcool, gás de madeira, biogás e óleos vegetais, nos motores de combustão. Atualmente, o alto preço do petróleo ${ }^{3}$ e de outras fontes de energia, assim como as pressões pela defesa do meio ambiente, vem transformando os biocombustíveis em grandes saídas para a substituição de combustíveis fósseis.

O uso da biomassa para geração de energia nos Estados Unidos e na Europa ainda é recente. Diferentemente dos resultados obtidos pelo Brasil, nestes países seu uso ainda não atingiu um estágio de maturação econômica (produção, geração, distribuição e uso final] e tecnológica [GURGEL, 2010].

\footnotetext{
² Disponível em: http:/ / www.macroprograma1.cnptia.embrapa.br

${ }^{3}$ Disponivel em: http:/ / www.cmegroup.com/trading/energy/nymex-daily-reports.html
} 
Atualmente, quase todo o etanol produzido no Brasil é proveniente da fermentação da sacarose retirada da cana-de-açúcar via processo conhecido e de custo relativamente baixo. Neste processo, o micro organismo geralmente utilizado é a levedura Saccharomyces cerevisae, que produz enzimas necessárias para que o processo de fermentação ocorra. A obtenção de açúcares simples a partir da sacarose, que antecede a fermentação, pode ser feita por enzimas da própria levedura: no caso da cana-de-açúcar, a sacarose é hidrolisada produzindo glicose e frutose pela enzima invertase [também chamada de sacarase] sintetizada pela $S$. cerevisae, de acordo com a reação abaixo [Figura 1] [MALTA, 2006].

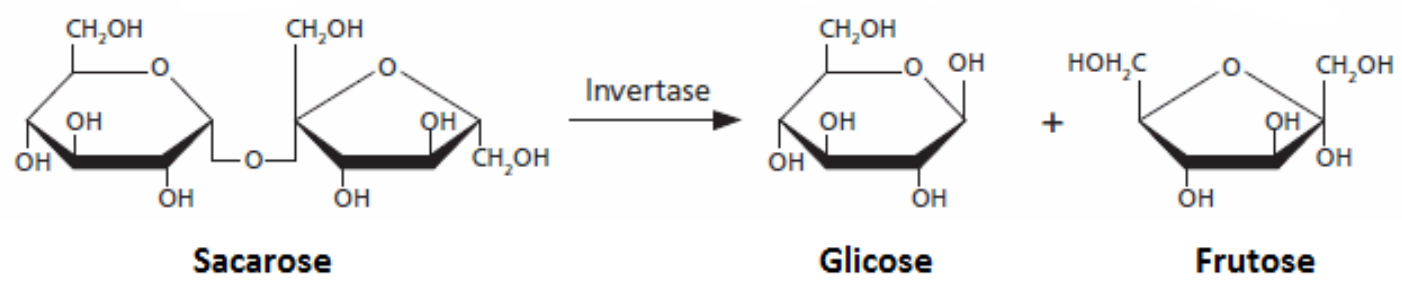

Figura 1 - Conversão enzimática da sacarose a glicose e frutose.

A obtenção do etanol a partir da biomassa [etanol celulósico ou de segunda geração], entretanto, necessita de um maior número de etapas de produção: colheita e transporte da biomassa, desconstrução da parede celular das plantas em seus respectivos componentes, isolamento de açúcares e lignina, através de prétratamento e sacarificação, e conversão dos açúcares a biocombustíveis, o que é feito via fermentação [RUBIN, 2008).

Neste contexto, qualquer matéria prima que contenha quantidade significativa de açúcares fermentesciveis [como a beterraba] ou de substâncias que possam ser convertidas a açúcares [como a biomassa lignocelulósica], pode a princípio ser utilizada para este fim [LACERDA, 2007]. A produção de etanol a partir da biomassa é mais vantajosa no que diz respeito à abundância e a diversidade das possíveis 
matérias-primas, em relação à utilização da sacarose presente na seiva da cana-deaçúcar. Além disso, a sacarose da cana-de-açúcar, por exemplo, têm outras aplicações comerciais como em alimentos, ao passo que a biomassa pode ser composta por rejeitos agrícolas, restos de plantas como o bagaço da cana-de-açúcar, palha de arroz, entre outros [DE PAULA, 2009].

Nesta perspectiva, as plantas podem ser vistas como sistemas coletores de energia solar e armazenadores de energia química. 0 armazenamento de energia em uma forma que pode ser acessada mais tarde via conversão química ou enzimática, distingue a biomassa de outras fontes renováveis de energia [GURGEL, 2010). A biomassa lignocelulósica é, portanto, uma fonte renovável abundante que vem se mostrando útil para a produção de energia [HIMMEL, 2007].

\section{BIOMASSA COMO FONTE DE MATERIAIS}

Polímeros sintéticos preparados a partir de matéria prima proveniente de petróleo são largamente usados na fabricação de produtos manufaturados, devido a suas boas propriedades e relativo baixo custo de produção. No entanto, estes polímeros geralmente são resistentes à degradação biológica quando descartados no meio ambiente [ROSA, GUEDES e BARDI, 2007].

Nos últimos anos, consideráveis esforços vêm sendo direcionados para o desenvolvimento e aplicação de compósitos, majoritariamente aqueles que envolvem a utilização de componentes que são oriundos de fonte renovável e seus derivados, pois estes apresentam baixo custo de produção, e podem ser degradados no meio ambiente por microorganismos, bactérias ou fungos. Wu [WU, 2012] desenvolveu compósitos de matriz de poli-[ácido lático] reforçada com sisal, e Pandey e colaboradores [PANDEY, LEE e AHN, 2010] usaram esta mesma matriz, com 
nanocristais de celulose como reforço. Em ambos os casos, boas propriedades mecânicas puderam ser obtidas. Åkesson e colaboradores [ÅKESSON et al., 2011] usaram como matriz uma resina proveniente do ácido lático, e fibras de linho como reforço, e os resultados comprovaram que este material é adequado para a indústria automobilística, entre outros fins. Ainda, Moriana e colaboradores (MORIANA et al., 2011] e Chang e colaboradores [CHANG et al., 2010] desenvolveram compósitos de amido termoplástico, com fibras lignocelulósica como reforço, e a utilização de materiais provenientes de fontes renováveis como substituintes para aqueles de fonte fóssil pode, mais uma vez, ser atestada. Assim, o uso destes materiais oferece uma atrativa solução para o problema de acúmulo de polímeros que possuem um tempo de degradação alto no meio ambiente [MORGADO, 2009].

Logicamente, para que polímeros e fibras naturais substituam, na medida do possível, os sintéticos, deve haver competitividade em termos de custo e de propriedades. Deve-se salientar que, considerando-se o avanço na legislação referente a impactos ambientais, em alguns casos o benefício obtido quando um material biodegradável substitui um material que não o seja, supera o efeito de um eventual acréscimo no custo de produção [CIACCO, 2003].

\section{MotIVAĈ̣̃O E JUSTIFICATIVA DO PRESENTE ESTUDO}

O presente trabalho está inserido em um amplo projeto que tem por objetivo a valorização das fibras vegetais, também chamadas de fibras naturais ou lignocelulósicas, assim como de lignina e celulose que podem ser obtidas a partir destas fibras. Este projeto está subdividido em diferentes linhas de pesquisa, entre as quais se destacam: o desenvolvimento de compósitos oriundos principalmente de fontes naturais renováveis [BARBOSA JÚNIOR et al., 2010; RAMIRES et al., 2010; 
MEGIATTO JÚNIOR et al., 2009; OLIVEIRA et al., 2008; MEGIATTO JÚNIOR et al., 2007], a derivatização de celulose para o desenvolvimento de biocompósitos a partir destes derivados (MORGADO et al., 2011; DE PAULA et al., 2008; ASS, BELGACEM e FROLLINI, 2006], e a sacarificação de material lignocelulósico, visando à produção de açúcares (LACERDA et al. 2012; DE PAULA et al. 2012; DE PAULA, 2009; LACERDA, 2007], o que corresponde à primeira etapa do processo de produção de bioetanol e é o tema principal do presente trabalho. Dentre as diversas fibras vegetais existentes, as de sisal correspondem a uma das mais utilizadas, devido às suas excelentes propriedades mecânicas [característica importante quando as fibras são aplicadas como reforço em compósitos], e ao seu alto teor de celulose, essencial no caso das reações de derivatização e sacarificação.

Considerando a área disponível para cultivo no país e a relevância do desenvolvimento de pesquisas relacionadas à utilização de biomassa, assim como a importância da formação de recurso humano na área, é imperativo que esforços sejam concentrados no sentido de valorizar a matéria prima proveniente da agricultura, incluindo os rejeitos, por exemplo, visando produção de biomateriais e bioetanol, além de outras aplicações.

É importante salientar que a utilização da biomassa em larga escala requer cuidados para que seu uso não traga impactos ambientais, como a destruição de fauna e flora com extinção de espécies, formação de desertos pelo corte não planejado ou descontrolado de árvores, destruição do solo pela erosão, entre outros. Por isso, é necessário levar em conta que a preocupação ambiental deve reger todo e qualquer projeto de utilização de biomassa.

O presente texto descreve um trabalho que corresponde à continuação de um estudo anterior [DE PAULA, 2009], no qual hidrólises de polpa de sisal não 
mercerizadas foram feitas em reações isotérmicas, assim como variando temperaturas entre 60 e $100^{\circ} \mathrm{C}$ em solução de $\mathrm{H}_{2} \mathrm{SO}_{4} 30 \%$ (v/v) e reações a $70^{\circ} \mathrm{C}$ em concentrações de ácido entre 30 e 50\% [v/v]. Além destes, mais três experimentos a $100^{\circ} \mathrm{C}$ e $30 \%$ de $\mathrm{H}_{2} \mathrm{SO}_{4}$ foram realizados utilizando polpas de sisal mercerizadas por 1, 2 e 3h. No presente trabalho, este estudo foi expandido, com o foco centrado em reações com menores concentrações de ácido sulfúrico, usando a mesma polpa celulósica [não mercerizada e mercerizada], acrescentando também o uso de ácido oxálico como catalisador, escolhido principalmente pela possibilidade de ser obtido a partir de fontes renováveis.

Em uma segunda etapa deste trabalho [descrita no Capítulo 3 deste texto], realizada em colaboração com a Universidade de Bordeaux - França [Unité Sciences du Bois et des Biopolymères, US2B - Université Bordeaux I], foi estudada a hidrólise enzimática da polpa de sisal, e a polpa residual deste processo foi aplicada em filmes baseados em quitosana. A hidrólise enzimática da polpa de sisal visando produção de bioetanol também foi considerada no presente estudo.

A biomassa talvez ainda não seja capaz de substituir totalmente as fontes de materiais e energia mais tradicionalmente utilizadas, mas certamente representa uma saída econômica significativa, que poderá contribuir para evitar o esgotamento das fontes de energia não renováveis. 


\section{OBJETIVOS}

objetivo geral deste estudo constituiu em valorizar uma fibra lignocelulósica vastamente produzida no país e que contem alto teor de celulose. Visou-se proporcionar um melhor entendimento e consequente melhoria do processo de hidrólise de polpa de sisal, com a perspectiva de utilização da glicose para a produção de etanol e de produção de fibras em escala micro e nanométrica para posterior aplicação em materiais.

De forma mais específica, este trabalho consistiu no estudo das etapas da hidrólise em meio ácido e enzimático da polpa celulósica de sisal, visando avaliar a composição dos licores de açúcares, assim como de produtos de decomposição obtidos, tendo como meta o uso da glicose gerada na produção de bioetanol. Além disso, as polpas remanescentes [não hidrolisadas] dos processos foram avaliadas quanto a características físico-químicas e morfológicas, visando relacioná-las à eficiência do processo, assim como a futuras aplicações do material não hidrolisado na preparação de materiais.

Em uma etapa inicial deste estudo, realizou-se uma série de reações de hidrólise ácida com o uso de ácido sulfúrico e polpa de celulose de sisal nativa, ou seja, que não 
passou pelo processo de mercerização. Tendo sido confirmada a importância deste prétratamento, para que melhores rendimentos quanto à produção de açúcares fossem atingidos, todas as etapas subsequentes foram realizadas com celulose mercerizada. Os ácidos sulfúrico e oxálico foram então empregados como catalisadores nas reações de hidrólise ácida de polpa de sisal mercerizada. Tanto os licores contendo o material hidrolisado quanto a polpa residual destas reações foram caracterizados.

A hidrólise da polpa de sisal também foi avaliada via catálise enzimática, com o uso do complexo enzimático Accellerase 1500 [Genencor]. Nesta etapa, a eficiência de dois pré-tratamentos nas fibras foi avaliada [mercerização e tratamento com ácido oxálico 0,9 molL-1]. Da mesma maneira como descrito para as reações via catálise ácida, tanto os licores contendo o material hidrolisado quanto a polpa residual destas reações foram caracterizados.

Finalmente, hidrólises ácida e enzimática foram usadas na preparação de micro e nanofibras para aplicação em biocompósitos de celulose/quitosana, e suas propriedades foram avaliadas. Esta etapa do trabalho é parte do projeto de Doutorado Sanduíche no Exterior [novembro/2009 - abril/2010] na Unité Sciences du Bois et des Biopolymères Université de Bordeaux /[França], sob orientação da Profa. Dra. Véronique Coma. 


\section{Capítulo}

\section{REVISÃo BIBLIOGRÁFICA}

\subsection{FiBRAS LIGNOCELULOSICAS - FiBRAS VegetaIS}

Fibras vegetais podem ser retiradas de diferentes partes da planta: caule [juta, malva, bagaço de cana-de-açúcar, bambu); folhas (sisal, bananeira, abacaxi, curauá], fruto [algodão, coco]; tronco [madeira], entre outras. Devido a isto, elas diferem consideravelmente uma das outras, mas possuem em comum o fato de serem constituídas basicamente por três componentes: celulose, lignina e hemiceluloses - também chamadas polioses (ROWELL et al., 1997; FENGEL e WEGENER, 1984].

\subsubsection{CELULOSE}

A celulose não está disponível na natureza em sua forma pura, de modo que o mais alto teor de celulose é encontrado nas fibras de algodão, nas quais raramente 
são detectadas mais que 5\% de outras substâncias. Mais comumente, a celulose está associada com outras substâncias como lignina e hemiceluloses, ambas em quantidades consideráveis. A madeira, por exemplo, apresenta entre 40 e 55\% de celulose, 15 e 35\% de lignina e 25 e 45\% de hemiceluloses, e estes teores variam de acordo com as características morfológicas de cada espécie [NEVELL e ZERONIAN, 1985]

Por se tratar de material natural abundante, a celulose tornou-se um assunto em pauta na ciência, tão logo ferramentas apropriadas para investigações científicas tornaram-se disponíveis para melhorar as propriedades dos materiais. Portanto, a celulose tem sido considerada como um dos mais importantes objetos de estudo na história da ciência dos polímeros [ZUGENMAIER, 2008]. Cabe mencionar que o primeiro material termoplástico desenvolvido pelo homem foi o nitrato de celulose, seguido pelo seu homólogo acetato, anteriormente àqueles provenientes de fontes fósseis [GANDINI, 2010].

Altos investimentos da indústria, aliados ao desenvolvimento econômico do Brasil tiveram impactos expressivos na produção de celulose na última década. 0 segmento praticamente dobrou o volume de celulose produzido nesse período, com um crescimento médio de 6,5\% ao ano, números singulares se comparados aos mercados mais tradicionais dessa indústria. Em 2008, o setor alcançou o posto de quarto produtor mundial de celulose, atrás apenas de Estados Unidos, Canadá e China. A posição foi mantida em 2009, quando o setor produziu 13,5 milhões de toneladas de celulose. Em 2010, a produção brasileira de celulose chegou a 14 milhões de toneladas [BRACELPA, 2012]. 


\subsubsection{Ocorrência}

A celulose é a base estrutural das células das plantas, sendo a mais importante substância natural produzida pelos organismos vivos, e é considerada uma fonte de matéria-prima quase que inesgotável frente ao aumento da demanda por produtos renováveis e ambientalmente corretos [FENGEL e WEGENER, 1984].

Inúmeras são as fontes a partir das quais a celulose pode ser isolada. Além de vegetais e algas, também pode ser produzida por bactérias como Acetobacter xylinum e por animais marinhos, como os tunicatos [NEVELL e ZERONIAN, 1985]. Entretanto, ainda é predominantemente isolada da madeira, o que a torna um material de lenta regeneração, considerando o número de anos que são necessários para que uma árvore possa ser utilizada para produzi-la. Dessa forma, esforços devem ser dirigidos para a utilização de celuloses de fontes de rápido crescimento, como sisal e cana-de-açúcar.

No Brasil, as duas principais fontes de madeira utilizadas para a produção de celulose são as florestas plantadas de pinus e de eucalipto, responsáveis por mais de 98\% do volume produzido [BRACELPA, 2012].

A celulose é estruturalmente composta por três níveis hierárquicos: [1] o nível molecular de uma única cadeia; [2] o nível supramolecular composto de cadeias contidas nas fibrilas e [3] o nível morfológico, por exemplo, a disposição e a agregação das fibrilas e os espaços intersticiais (MORGADO, 2009). Para os propósitos deste trabalho torna-se necessária uma descrição estrutural da celulose, a níveis molecular e supramolecular, tópico que será discutido na sequência. 


\subsubsection{A estrutura molecular}

Em 1838 o químico francês Anselme Payen sugeriu que as paredes celulares de uma extensa gama de plantas seriam constituídas por uma substância em comum, à qual deu o nome de celulose. Payen mostrou por análise elementar que os tecidos das plantas deveriam ser formados por um componente majoritário composto de aproximadamente 44\% de carbono, 6\% de hidrogênio e 50\% de oxigênio, o que é equivalente a uma fórmula empírica de $\mathrm{C}_{6} \mathrm{H}_{10} \mathrm{O}_{5}$ e massa molar de $162 \mathrm{gmol}^{-1}$ [NEVELL e ZERONIAN, 1985]. Em 1922, Staudinger introduziu a representação da estrutura da celulose [HON, 1994], aceita até os dias de hoje.

A celulose é um homopolímero linear composto de unidades de $\beta$-Dglicopiranose unidas por ligações glicosídicas do tipo $\beta-[1 \rightarrow 4]$. A molécula de $\beta$-Dglicopiranose corresponde à molécula de glicose, e é assim denominada de acordo com o sistema de nomenclatura baseado no número de átomo de carbonos, fazendo referência ao heterociclo com oxigênio no anel, pirano [Figura 2).

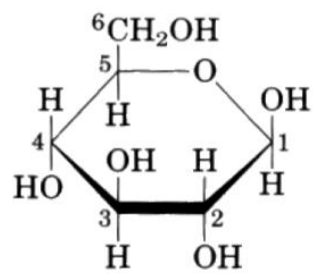

$\beta$-D-glicopiranose<smiles>C1=COCCC1</smiles>

Pirano

Figura 2 - Moléculas de $\beta$-D-glicopiranose e pirano.

$\mathrm{Na}$ cadeia de celulose, as unidades de $\beta$-D-glicopiranose, estão na conformação cadeira e os substituintes $\mathrm{HO}-2$, $\mathrm{HO}-3$ e $\mathrm{CH}_{2} \mathrm{OH}$ estão orientados equatorialmente [Figura 3]. Nessa conformação os grupos hidroxilas livres estão posicionados no plano do anel, ou seja, em equatorial, enquanto os átomos de hidrogênio estão posicionados em uma posição perpendicular, dita axial [SJÖSTRÖM, 1991]. A anidroglicose, que estruturalmente corresponde à remoção de uma 
molécula de água da unidade de glicose, é polimerizada em longas cadeias de celulose. A unidade repetitiva da celulose consiste em duas moléculas de anidroglicose, e a este dissacarídeo é dado o nome de celobiose (MOHAN, PITTMAN e STEELE, 2006]. Os grupos hidroxila terminais exibem diferentes reatividades [KLEMM et al., 1998].

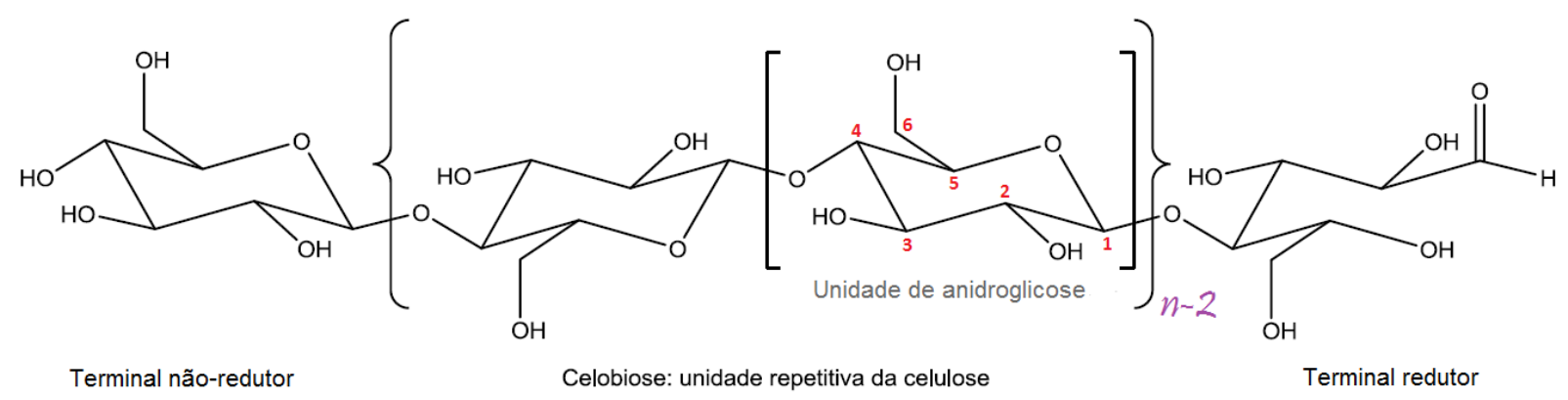

Figura 3 - Estrutura molecular da celulose (KLEMM et al., 1998).

A presença de ligações hidrogênio intramoleculares entre as hidroxilas diretamente ligadas a C2 e C6 de dois anéis de anidroglicose consecutivos de uma mesma cadeia exerce influência na conformação assumida pela cadeia. Estas ligações, esquematicamente descritas na Figura 4, são responsáveis pela rigidez considerável da cadeia.

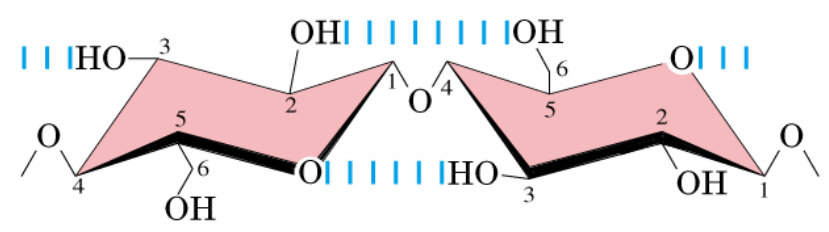

Figura 4 - Representação esquemática das ligações hidrogênio presentes na unidade repetitiva da celulose [celobiose].

\subsubsection{A estrutura supramolecular}

Devido a sua constituição química e sua conformação espacial, as cadeias de celulose possuem uma forte tendência frente à agregação, gerando estruturas altamente ordenadas, proporcionadas pela presença de uma rede estendida das 
ligações hidrogênio intramoleculares supracitadas [Figura 4] e, de forma igualmente importante, das ligações hidrogênio intermoleculares [Figura 5].

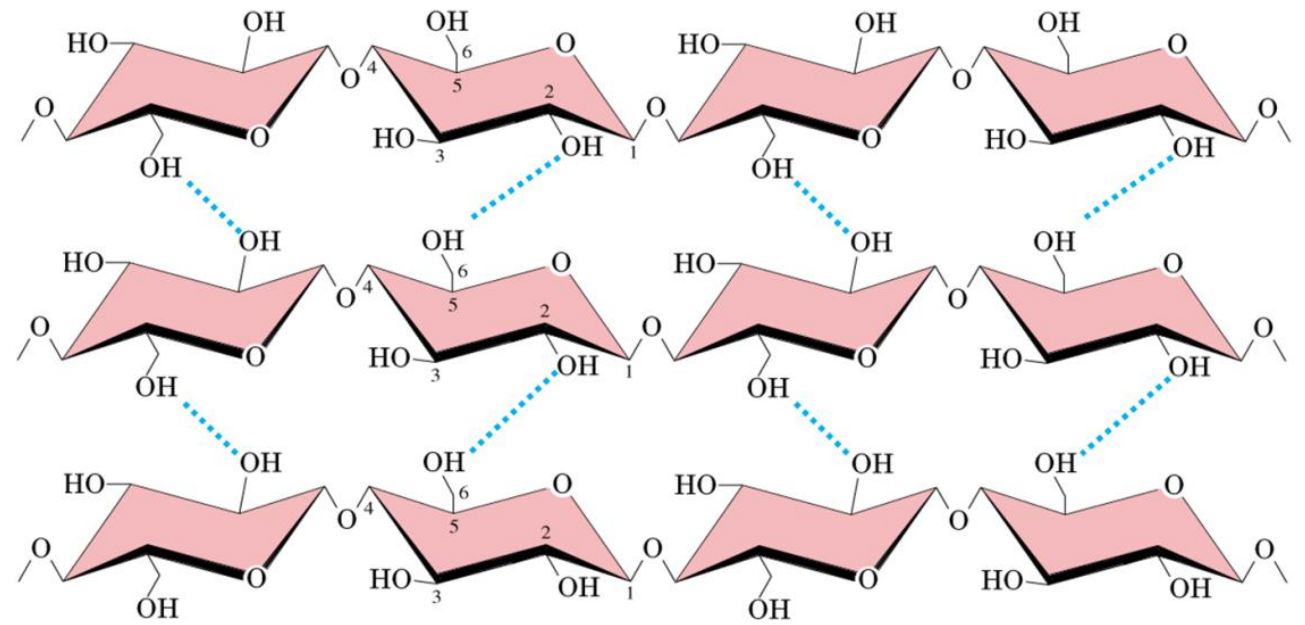

Figura 5 - Representação esquemática das ligações hidrogênio presentes entre as cadeias de celulose.

As ligações hidrogênio intermoleculares são o fator predominantemente responsável pela coesão intercadeias. Esta coesão, de extrema relevância em todas as reações de celulose em meio heterogêneo, é favorecida pela alta regularidade espacial dos sítios formadores da ligação hidrogênio [KLEMM et al., 1998].

As ligações hidrogênio entre os grupos hidroxilas são responsáveis pela estruturação da fibra vegetal, ou seja, as moléculas de celulose se alinham, formando as microfibrilas. As microfibrilas se agregam em fibrilas mais espessas [macrofibrilas] que, por sua vez, se ordenam para formar as sucessivas paredes celulares da célula vegetal [MORGADO, 2009].

A organização das macromoléculas em uma fibra de celulose não é uniforme ao longo de toda a estrutura, e assume-se que existem regiões de baixa ordem como também regiões altamente cristalinas e organizadas. Através de evidências experimentais é possível interpretar adequadamente a estrutura supramolecular da 
celulose considerando um modelo de duas fases e, assumindo regiões de baixa ordem, ou não cristalinas, e regiões altamente ordenadas, ditas cristalinas [GURGEL, 2010].

\subsubsection{Cristalinidade e polimorfismo da celulose}

As microfibrilas de celulose são constituídas de regiões ordenadas tridimensionalmente [cristalitos], devido à regularidade à grande quantidade de ligações hidrogênio nas cadeias, que se alternam a regiões desordenadas [regiões não cristalinas]. Estas regiões não possuem fronteiras bem definidas e a razão entre as mesmas pode variar, de acordo com a origem da celulose [ALMEIDA, 2009].

No que diz respeito às regiões cristalinas, as diferentes conformações que o grupo hidroximetila $\left[-\mathrm{CH}_{2} \mathrm{OH}\right]$ pode assumir geram diferentes estruturas de empacotamento das cadeias de celulose. A celulose exibe um polimorfismo considerável e, até o momento, sete polimorfos de celulose são conhecidos $\left[I_{\alpha}, I_{\beta}, I I, I I_{1}, I \|_{\|,}, V_{\|}, I_{\|}\right]$ [JARVIS, 2003; ZUGENMAIER, 2001; O'SULLIVAN, 1997], que diferem nas dimensões da cela unitária, dentre as quais, as que ocorrem mais frequentemente são as formas I e II.

Os polimorfos $I_{\alpha}$ e $I_{\beta}$ são aqueles encontrados na natureza. Baseados em dados de ${ }^{13} \mathrm{C}-\mathrm{RMN}$ de alta resolução no estado sólido, VanderHart e Atalla concluíram que os domínios cristalinos da celulose nativa são uma mistura de polimorfos $I_{\alpha}$ e $I_{\beta}$ [ATALLA e VANDERHART, 1984; VANDERHART e ATALLA, 1984]. De acordo com os autores, a celulose bacteriana e a celulose extraída da alga Valonia ventricosa possuem alto teor do polimorfo $I_{\alpha}$, enquanto na celulose extraída de rami, algodão e madeira, por exemplo, o polimorfo $I_{\beta}$ é dominante. Sugijama e colaboradores [SUGIJAMA, VOONG e CHANZY, 1991] descreveram, com base em experimentos de difração de elétrons, que a fase $I_{\alpha}$ é 
uma estrutura triclínica P-1, com uma cadeia de celulose por cela unitária, e a fase $\mathrm{I}_{\beta}$ corresponde a uma cela unitária monoclínica P-2 $2_{1}$, com duas cadeias por cela unitária. De acordo com Yamamoto e Horii [YAMAMOTO e HORII, 1993], a fase $\mathrm{I}_{\alpha}$ é metaestável e pode se converter à fase $I_{\beta}$, termodinamicamente mais estável. Celuloses $I_{\alpha}$ e $I_{\beta}$ podem ser encontradas na mesma amostra e ao longo da mesma microfibrila [NISHIYAMA et al., 2003), o que fez com que as primeiras investigações sobre a estrutura cristalina da celulose I fossem bastante difíceis e controversas [RINALDI e SCHÜTH, 2009].

A estrutura de cadeias paralelas, característica da celulose I [Figura 6], geralmente encontrada na natureza, ocorre quando os grupos $-\mathrm{CH}_{2} \mathrm{OH}$ de cadeias adjacentes se encontram na mesma conformação. A estrutura antiparalela, característica da celulose II [Figura 6], ocorre quando cadeias adjacentes possuem os grupos $-\mathrm{CH}_{2} \mathrm{OH}$ em diferentes posições [ZHAO et al., 2006]. 

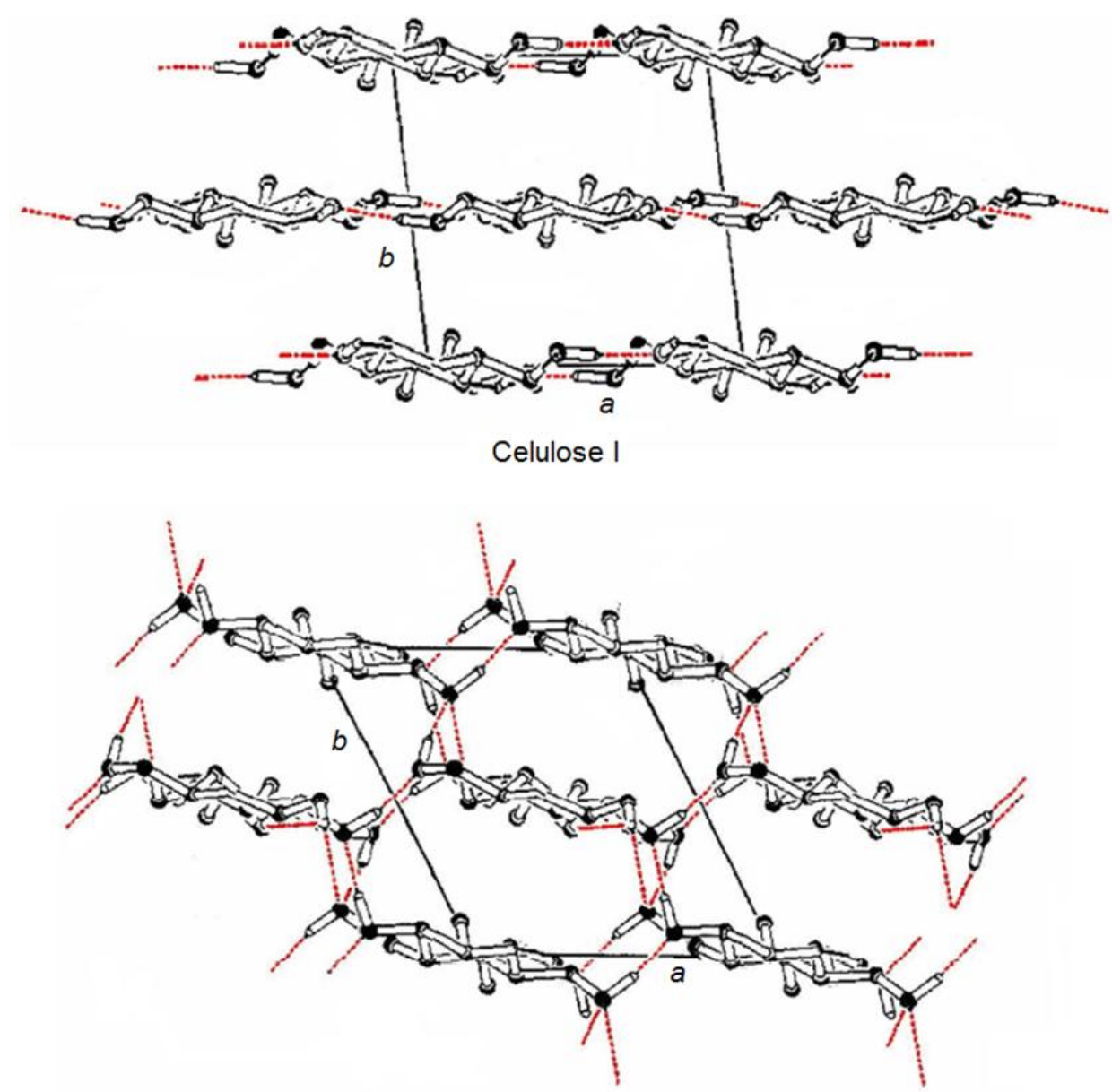

Celulose II

Figura 6 - Projeções das celas unitárias da celulose I e celulose II [KROON-BATENBURG e KROON, 1997].

Embora a celulose I seja a forma em que a celulose se encontra na natureza, não é a forma termodinamicamente mais estável. 0 empacotamento antiparalelo da celulose II permite a formação de ligações hidrogênio em maior extensão, formando arranjos em escala tridimensional, resultando numa estrutura mais estável e de menor energia, o que explica parcialmente porque a celulose II não pode ser revertida à celulose I, menos estável [KROON-BATENBURG e KROON, 1997].

\subsubsection{Reatividade}

Conforme mencionado, a celulose é formada por longas cadeias que consistem de unidades repetitivas de celobiose [Figura 3]. Essas longas cadeias agregam-se para formar a supraestrutura da celulose nativa na planta. 0 modo pelo qual as cadeias de 
celulose se agregam está intimamente relacionado com a acessibilidade da celulose, que é um fator importante que controla sua reatividade química. A acessibilidade de cadeias de celulose significa a susceptibilidade da estrutura da celulose à interação com reagentes químicos, assim como moléculas de solventes, quando o processo se refere à dissolução deste polissacarídeo.

A unidade glicopiranosídica presente na estrutura da celulose tem três grupos hidroxila reativos: dois álcoois secundários, em C2 e C3, e um primário, em C6 [Figura 3]. Dentre as três hidroxilas, aquela ligada ao carbono primário $[\mathrm{C} 6-\mathrm{OH}]$ seria a mais reativa, por estar menos impedida estericamente [ASS, CIACCO e FROLLINI, 2006]. Embora esta ordem de reatividade seja confirmada para muitos derivados de celulose, exceções já foram relatadas anos atrás [SAMARANAYAKE e GLASSER, 1993; DAWSEY e McCORIICK, 1990].

Os grupos hidroximetila das unidades de anidroglicose assumem um papel fundamental na reatividade da celulose. Vários estudos usando difração de raios X de alta resolução, difração de nêutrons, e simulação computacional visaram elucidar as ligações hidrogênio dos grupos hidroximetila, sua dinâmica na estrutura da celulose [WADA et al., 2008; KROON-BATENBURG e KROON, 1997], e a formação de ligações hidrogênio é considerada um dos fatores que mais influenciam as propriedades físicas da celulose [KONDO, 1997; KONDO, 1994]. Mesmo que solventes possam estabelecer ligações hidrogênio, a grande dificuldade na solubilização da celulose está diretamente relacionada à sua conformação estrutural. A interação entre os grupos hidroxila via ligações hidrogênio entre as cadeias [Figura 5] limita o acesso de agentes aos grupos funcionais, o que dificulta tanto sua solubilização como reações. solvente ideal para a celulose é, portanto, aquele capaz de romper as ligações hidrogênio intermoleculares [RAMOS et al. 2011; REGIANI et al., 1998]. 
Há também outros fatores que podem influenciar negativamente o acesso de reagentes e catalisadores, quando se trata de fibras lignocelulósicas. Entre estes fatores destacam-se a porosidade da fibra [área superficial acessível], a cristalinidade, e o teor de hemiceluloses e lignina. A presença da matriz de hemiceluloses e lignina que envolve as cadeias de celulose dificulta o acesso, sendo necessário um tratamento prévio para a retirada da lignina [polpação] e idealmente de hemiceluloses, para que seja facilitado o acesso à celulose, quando esta corresponde ao material reativo de interesse. Neste caso adicionalmente, a presença de lignina e hemicelulose pode gerar produtos colaterais indesejáveis [DE PAULA, 2009]. No caso dos pré-tratamentos visando à reação de hidrólise de material lignocelulósico, estes devem cumprir os seguintes requisitos: [1] aumentar a formação de açúcares ou a habilidade de formar açúcares em uma etapa posterior; [2] evitar a degradação ou a perda dos carboidratos; [3] evitar a formação de subprodutos que inibam a hidrólise e a posterior fermentação dos açúcares formados; [4] possuir bom custo/benefício [SUN e CHENG, 2002].

Em suma, as características físicas e químicas da estrutura supramolecular da celulose impõem importantes barreiras cinéticas para a sua reatividade. Vários prétratamentos nos materiais lignocelulósicos, como os que levam a degradação química parcial, fragmentação mecânica, ativação por intumescimento, entre outros, que rompem parcialmente a estrutura da celulose, são comumente aplicados a fim de melhorar a reatividade da celulose frente a reações de hidrólise em meio heterogêneo, contexto em que se insere o presente estudo. 


\subsubsection{Mercerizacão}

Um melhor acesso entre os grupos funcionais presentes na estrutura da celulose e os reagentes químicos pode ser viabilizado por tratamentos que levam ao intumescimento ["swelling"], que interfere nas ligações hidrogênio intermoleculares e diminui a cristalinidade da celulose. 0 intumescimento, que corresponde à interação física entre os grupos hidroxila da celulose e agentes químicos, pode ser classificado como intercristalino e intracristalino (NEVELL e ZERONIAN, 1985).

No intumescimento intercristalino, que é o caso do intumescimento com a água, o agente intumescedor penetra apenas nos interstícios entre as unidades das estruturas fibrilares e intumesce as áreas menos ordenadas, causando o inchamento das fibrilas da celulose. No intumescimento intracristalino, o agente entra nos interstícios fibrilares e penetra nas regiões não cristalinas e cristalinas, provocando, muitas vezes, mudanças drásticas na rede cristalina [NEVELL e ZERONIAN, 1985].

A mercerização [ASTM 1695-07], que consiste em um processo de intumescimento intracristalino, é um importante pré-tratamento das fibras celulósicas com solução aquosa concentrada de uma base forte, que pode ser empregado para melhorar propriedades da celulose como reatividade química, tração, rugosidade, entre outras [SAMEl et al., 2008; KIM, LEE e YOON, 2006; DINAND et al., 2002]. A extensão com que estas mudanças ocorrem dependem, principalmente, de tempo de tratamento, temperatura, concentração de $\mathrm{NaOH}$, razão celulose/solução alcalina, grau de polimerização e fonte de celulose utilizada. Celuloses mercerizadas são preparadas segundo a sequência: [1] agitação da amostra de celulose com solução de $\mathrm{NaOH}$, [2] lavagem com água para remover todo $\mathrm{NaOH}$, [3] secagem da celulose. 
Dentre as possíveis interações do íon sódio com os átomos das cadeias de celulose, destacam-se as interações nas regiões de maior polaridade envolvendo os grupamentos hidroxila. A Figura 7 mostra as possiveis interações que influenciam na ocorrência das rupturas e reposicionamentos das ligações hidrogênio. As interações deste íon com grupos hidroxila da cadeia de celulose pode levar a mudanças conformacionais, resultando em diferentes formas cristalinas, descritas na sequência [FINK et al., 1995].

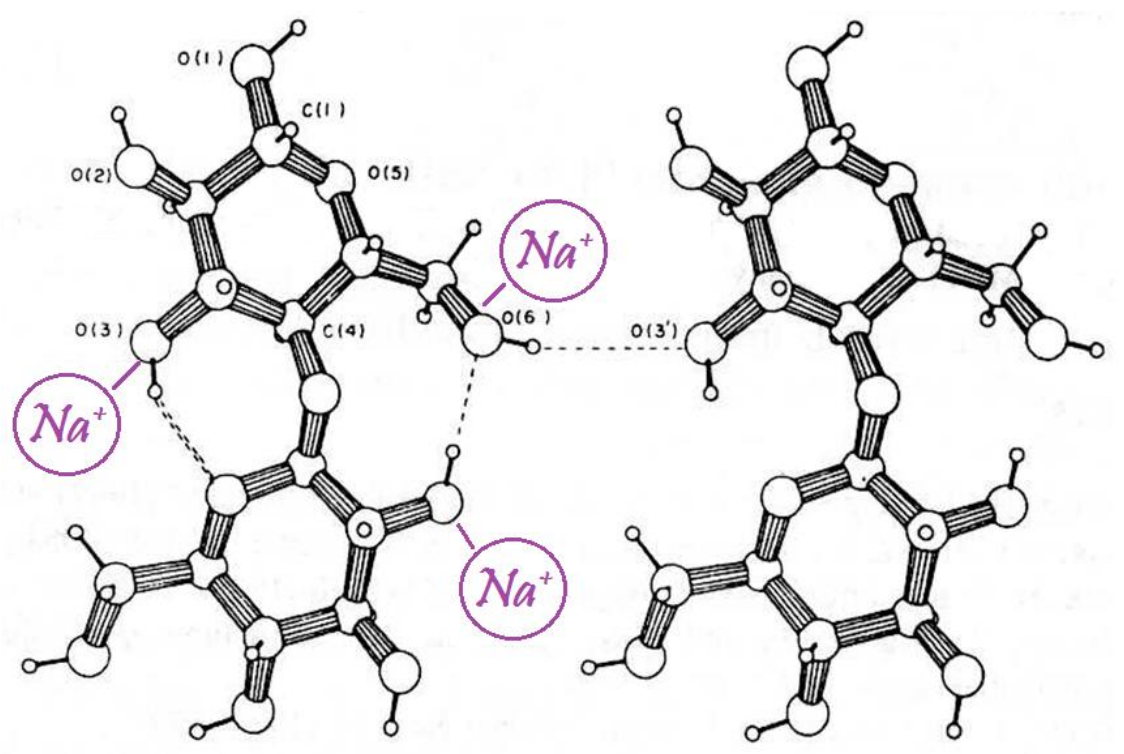

Figura 7 - Representação de estrutura de celulose I, mostrando possiveis interações dos íons sódio nas ligações hidrogênio inter-e intramoleculares [FINK et al., 1995].

Durante este processo, há uma alteração estrutural das cadeias celulósicas nas regiões cristalinas [Figura 8]. Isto se dá devido ao fato de o grupo hidroximetila $\left[-\mathrm{CH}_{2} \mathrm{OH}\right]$ assumir diferentes conformações. Assim, a estrutura de cadeias paralelas com os grupos hidroximetila [celulose I], passa a se tornar antiparalela [celulose II], resultando em cadeias adjacentes com tais grupos em posições diferentes. Dessa forma há formação de ligações hidrogênio em maior extensão e ordenação [Figura 6], gerando uma estrutura mais estável. 

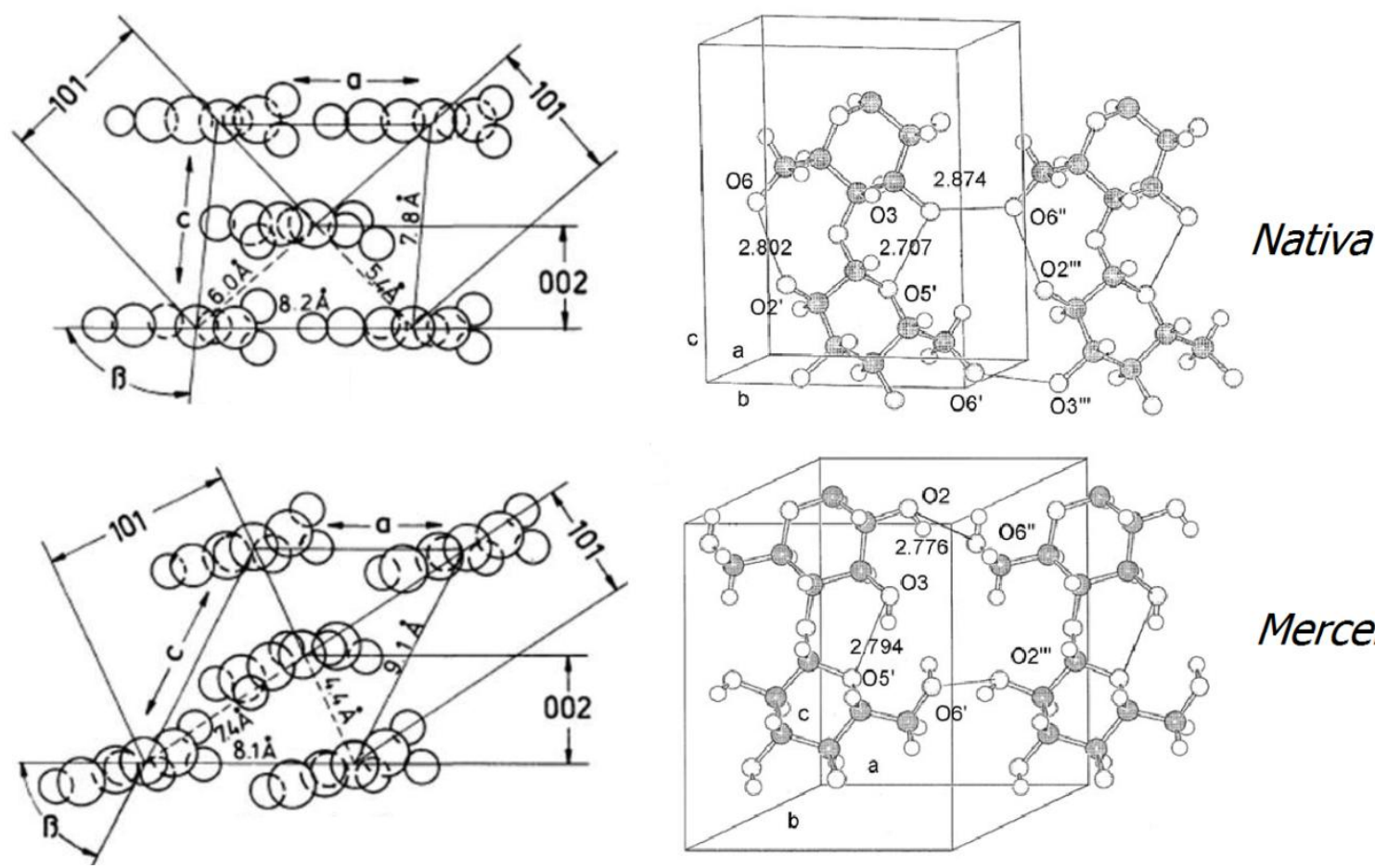

Mercerizada

Figura 8 - Algumas distâncias referentes ao arranjo dos átomos no plano para celulose I [nativa] e celulose II [mercerizada] [KRÄSSIG, 1993].

O processo de mercerização também promove a purificação da celulose, pois remove impurezas como ceras, hemiceluloses, pectinas e sais mineirais eventualmente presentes [STANA-KLEINSCHEK, STRNAD e RIBITSCH, 1999], restando a $\alpha$-celulose, que é a celulose pura, quando o processo atinge eficiência máxima.

Dependendo das condições que são usadas, como temperatura e concentração da solução, o tratamento alcalino [mercerização] também pode agir de maneira degradativa na celulose. A degradação de polissacarídeos por hidrólise, em meio alcalino, pode envolver um mecanismo de eliminação- $\beta$, ocorrendo a partir da extremidade não redutora das cadeias [Figura 3], que pode levar a uma diminuição da massa molar média. A Figura 9 mostra o mecanismo da possível hidrólise das ligações glicosídicas da celulose em meio alcalino. 


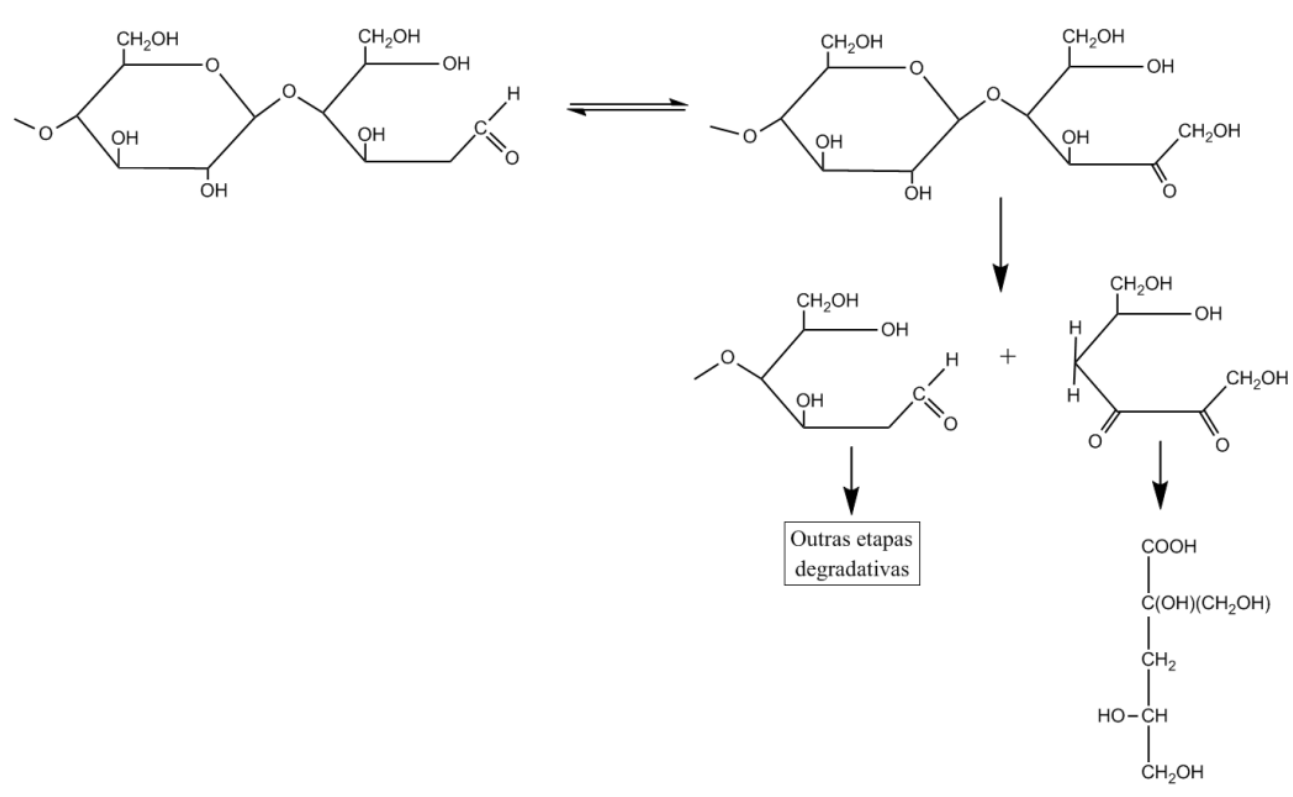

Figura 9 - Mecanismos de hidrólise básica da celulose [adaptado de FROLLINI, 2002].

O intermediário 2,3- $\alpha$-dicarbonila mostrado na Figura 9 já foi isolado, o que reforça esta proposta de mecanismo. Em temperaturas elevadas, os produtos de reação podem ser mais numerosos, com produção de ácido fórmico, provavelmente formado a partir da degradação deste intermediário [FROLLINI, 2002].

Deve-se ressaltar que, assim como a celulose, as hemiceluloses podem sofrer degradação nesse tratamento alcalino, podendo em muitos casos, ser eliminada totalmente, facilitando ainda mais a posterior hidrólise. As hemiceluloses não estão em regiões cristalinas e possuem baixa massa molar média, o que facilita sua degradação.

\subsubsection{HEMICELULOSES}

As hemiceluloses ocorrem em associação íntima com a celulose e a lignina, e contribuem para a rigidez da parede celular das plantas em tecidos lignificados [GURGEL, 2010]. Possuem uma composição heterogênea de várias unidades de açúcares, dependendo do tipo de planta, sendo classificadas como xilanas, unidades de $\beta$-1,4-Dxilose ligadas, mananas, unidades de $\beta$-1,4-D-manose ligadas, arabinanas, unidades de $\alpha$ - 


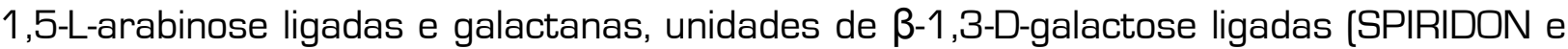
POPA, 2008].

A xilana é um dos maiores constituintes das hemiceluloses nos materiais lignocelulósicos [EBRINGEROVA e HEINZE, 2000]. Sua estrutura tem um esqueleto linear que consiste de resíduos de $\beta$-1,4-D-xilanopiranose ligados. Estes podem ser substituídos com ramificações contendo grupos acetila, arabinosila e glicoronosila, dependendo da fonte botânica [SPIRIDON e POPA, 2008].

Em plantas anuais, as principais hemiceluloses são representadas por xilanas, que são mais heterogêneas do que as xilanas de tecidos de madeira (ASPINALL, 1980]. Estas plantas contêm ambos ácidos glicurônico e/ou 4-0-metil-éter e arabinose ligadas aos carbonos C2 e C3 das unidades de xilose. Ambas xilana e glicomananas podem estar parcialmente acetiladas [WILKIE, 1979].

De fato, no sisal, as hemiceluloses são predominantemente constituídas por xilanas. De acordo com Megiatto Júnior [MEGIATTO JÚNIOR et al., 2007), elas constituem cerca de $68 \%$ do total das hemiceluloses do sisal. A Figura 10 mostra a composição e a porcentagem dos açúcares presentes nas hemiceluloses do sisal.

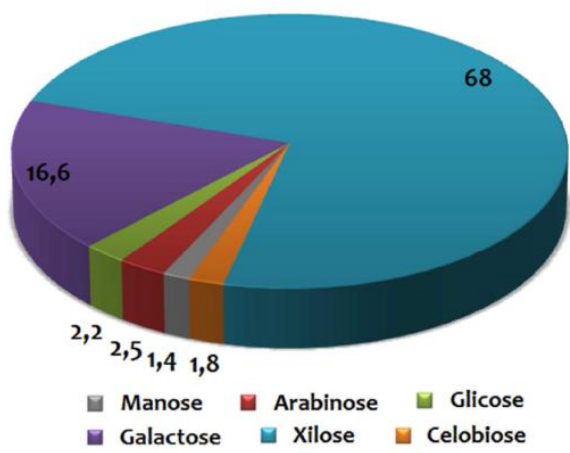

a

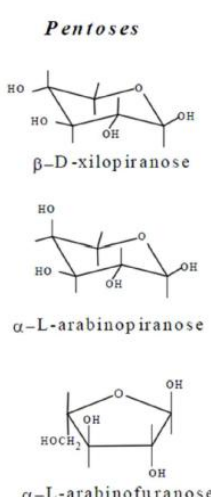

$\alpha-$ - arabinofuranto

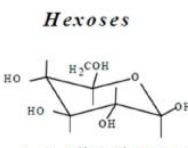

$\beta$-D-glicopiranose

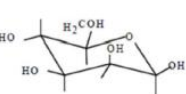

$\beta$-D-manopiranose ácido $\alpha-D-4-0$-metil-glicourònico

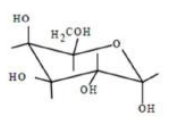

$\alpha-\mathrm{D}$-galactop iranose

b
Ácidos hexurônicos
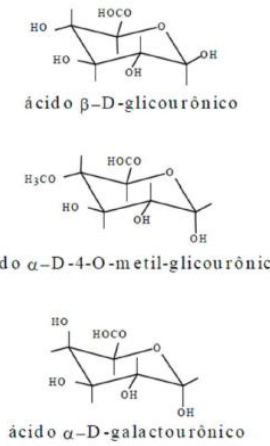

ácido $\alpha$-D-galactourônico

Figura 10 - (a) Composição das hemiceluloses presentes no sisal (MEGIATTO JÚNIOR et al. 2007] e [b] estruturas químicas de unidades de açúcares presentes na hemicelulose. 


\subsubsection{LIGNINA}

O termo lignina define uma família de macromoléculas complexas e altamente ramificadas de cadeias alifáticas e aromáticas (NEVELL e ZERONIAN, 1985).

A presença da lignina na parede celular dos vegetais reflete a importância de uma matriz rígida em torno das fibras de celulose/hemicelulose, assumindo, principalmente, funções de coesão e barreira frente à umidade [BURTON, GIDLEY, e FINCHER, 2010].

As ligninas são naturalmente sintetizadas por reações combinadas de acoplamento fenólico, induzidas por radicais livres gerados enzimaticamente, através das quais três monômeros (lignóis, Figura 11), reagem com o radical em crescimento, como em uma polimerização em cadeia clássica (RALPH et al., 2004]. Como resultado, o grande número de sequências possíveis na estrutura macromolecular torna extremamente improvável que duas macromoléculas de lignina sejam idênticas.<smiles>OC/C=C/c1ccc(O)cc1</smiles>

Álcool p-cumarílico<smiles>COc1cc(/C=C/CO)ccc1O</smiles>

Álcool coniferílico<smiles>COc1cc(/C=C/CO)cc(OC)c1O</smiles>

Álcool sinapílico

Figura 11 - Álcoois precursores fundamentais para a formação da lignina [GANDINI, 2010].

$\mathrm{Na}$ biomassa vegetal, as cadeias de celulose se associam às hemiceluloses para formar estruturas lineares de alta resistência conhecidas como microfibrilas. Camadas sobre camadas de microfibrilas compõem as fibras da parede celular das plantas. As cadeias celulósicas que fazem parte de regiões cristalinas e não cristalinas são rodeadas por hemiceluloses que se associam entrecruzando-se com a lignina, nas fibras lignocelulósica [GANDINI, 2010] (Figura 12]. 


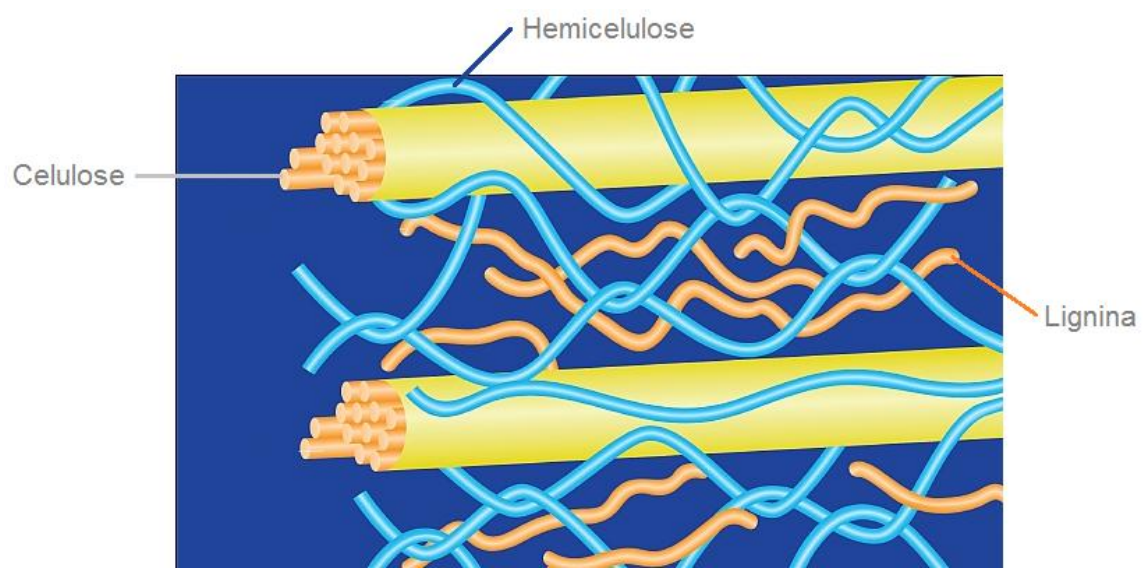

Figura 12 - Esquema representativo da associação entre as estruturas de celulose, hemicelulose e lignina [Adaptado de: http:/ / www.scidacreview.org/0905/images/biofuel01.jpg].

No presente estudo, a fibra lignocelulósica de partida consistiu na fibra de sisal.

\subsection{SISAL}

A expansão do sisal do seu centro de domesticação, localizado na região montanhosa mesoamericana, ocorreu rapidamente após a conquista deste território pelos espanhóis. No início da ocupação do extremo norte do México, os nativos designados para a produção rural carregavam plantas de Agave sp. com o objetivo de preparar o pulque [bebida fermentada proveniente do suco das folhas de plantas do gênero Agave). Este costume, que ainda persiste na região, foi preponderante para a dispersão do sisal na região norte do continente [SINDIFIBRAS, 2012]. De acordo com sua classificação taxonômica, o sisal pertence ao reino Plantae, filo Magnoliophyta, classe Equisetopsida, subclasse Magnoliidae, superordem Lilianae, ordem Asparagales, familia Asparagaceae, subfamilia Agavoideae, gênero Agave e espécie A. sisalana [Figura 13]. 


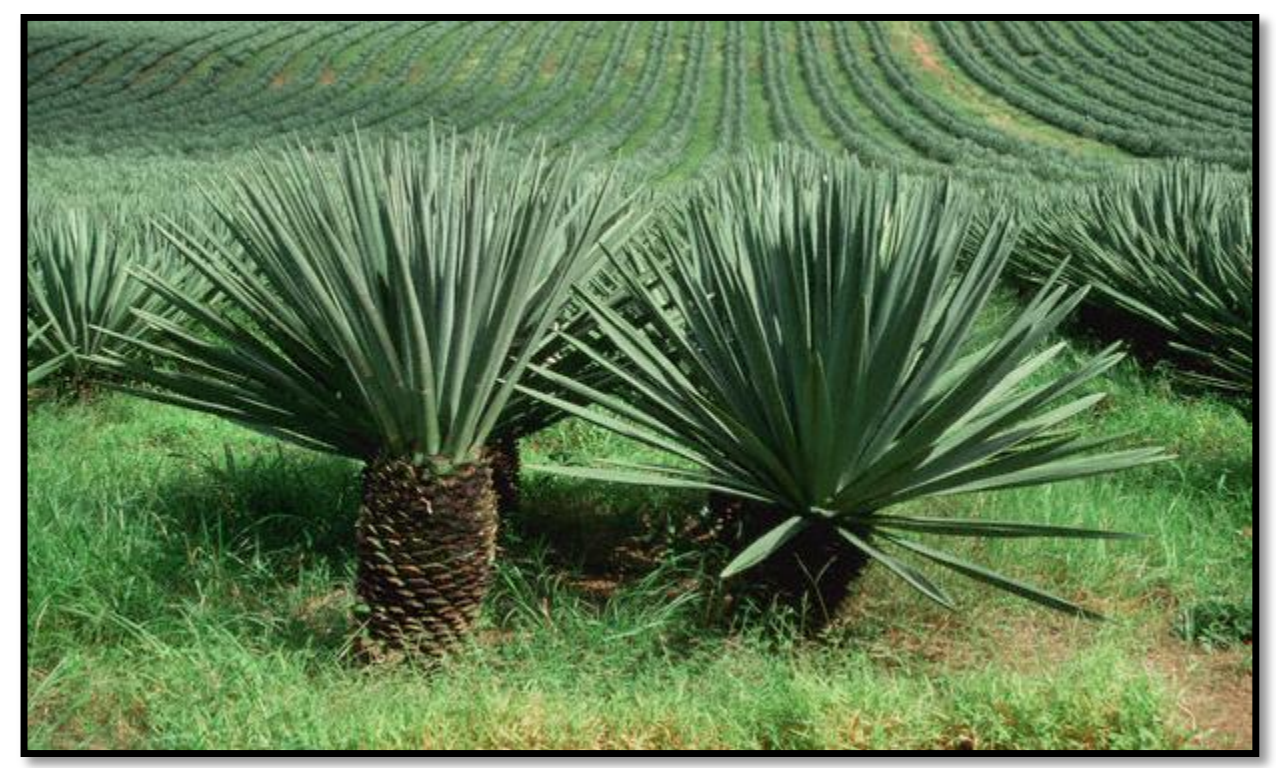

Figura 13 - Planta de sisal.

(Fonte: http://www.corbisimages.com/images/CorbisEC001 138.jpg?size=67\&uid=671 caeb3-f2e8-4505-b400-f404f020ae16 .

sisal é uma planta de elevada complexidade morfofisiológica, e apresenta metabolismo fotossintético que possibilita maior aproveitamento da água, ou seja, abre os estômatos durante a noite, para se beneficiar do orvalho e não perder água via transpiração durante o dia. É uma espécie que prefere locais de altitude e possui elevada resistência à seca e ao estresse térmico, apresentando eficiência transpiratória e gastando pouquíssima água para produzir fitomassa - menos de $100 \mathrm{~g}$ de água por grama de fitomassa, contra quase dez vezes mais no caso do algodão herbáceo. Prefere solos com elevados teores de cálcio e que não encharquem facilmente [SINDIFIBRAS, 2012].

O sisal é a principal fonte de extração de fibras duras vegetais do mundo. No século XIX, em virtude de interesses coloniais, diversas indústrias de fibras de sisal prosperaram na Indonésia e nas Filipinas. Este fenômeno se repetiu no século XX, na região oeste da África [principalmente no Quênia e na Tanzânia] e no Nordeste do Brasil. Atualmente, o Brasil e os países do oeste africano se destacam na produção mundial de sisal e nestes países foram desenvolvidos diversos sistemas de produção, 
colheita e desfibramento, de acordo com as condições particulares locais [SINDIFIBRAS, 2012].

O sisal foi plantado pela primeira vez no Brasil em 1903, no estado da Bahia, sendo posteriormente levado para outros estados do nordeste [MEGIATTO JÚNIOR, 2006]. Seu cultivo ocupa uma extensa área de solos pobres em nutrientes na região semiárida dos Estados da Bahia, Paraíba e Rio Grande do Norte, em regiões onde, não raro, é a única alternativa de cultivo com resultados econômicos satisfatórios [SANTOS et al., 2010].

No Brasil, a agaveicultura se concentra em áreas de pequenos produtores, com predomínio do trabalho familiar por meio de sua cadeia produtiva, que começa com as atividades de manutenção das lavouras, colheita, desfibramento e beneficiamento da fibra e termina com a industrialização e a confecção de artesanato [SINDIFIBRAS, 2012]. A cultura é de fundamental importância na economia nordestina porque torna produtivas regiões semiáridas, com poucas alternativas econômicas, sendo um setor que emprega grande volume de mão-de-obra, contribuindo para fixar o homem no campo.

De acordo com a FAO [Food and Agricultural Organization of the United Nations], o Brasil vem ocupando posição de destaque como o principal produtor mundial de sisal (Figura 14], sendo o estado da Bahia responsável por $80 \%$ da produção nacional desta fibra. Apesar da importância do sisal para o país, o Brasil ainda é carente de publicações científicas que tratem o assunto de forma abrangente e sistemática [SINDIFIBRAS, 2012]. 


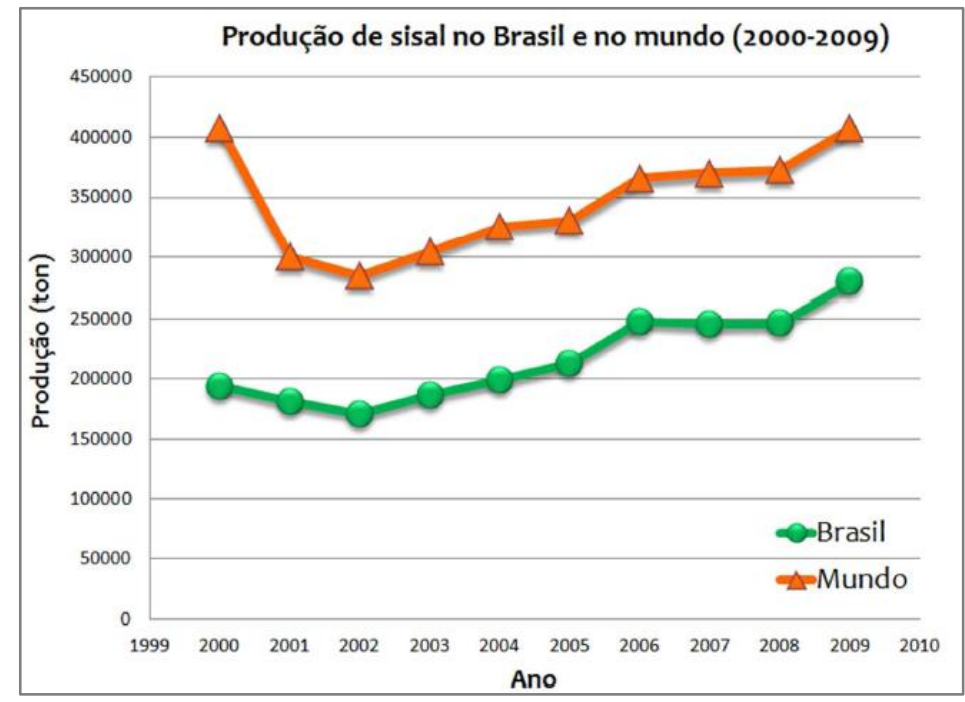

Figura 14 - Produção de sisal no Brasil e no mundo de 2000 a 2009, de acordo com a FAO [2011].

O cultivo da planta é feito de maneira muito simples na região nordeste do Brasil. Os tratos culturais são resumidos a carpina e a erradicação dos brotos, também chamados de "filhotes". O corte é feito bem rente ao tronco, com cuidado de se deixar pelo menos dez folhas na planta. 0 próximo passo corresponde ao desfibramento, processo em que se separa a polpa das fibras, raspando as folhas mecanicamente. Após esta fase, as fibras são lavadas, secas e enfardadas antes de seguirem para a indústria [MEGIATTO JÚNIOR, 2006].

Do ponto de vista anatômico, as fibras extraídas do sisal se inserem no grupo de fibras denominadas estruturais, cuja função é dar sustentação e rigidez às folhas. Quando se procede a extração, as fibras surgem na forma de feixes, variando em comprimento desde $40 \mathrm{~cm}$ até $2 \mathrm{~m}$ [média de 1,2 m], mais espessas na base, de seção angular ou quase cilíndrica, com diâmetro de aproximadamente 100-300 um [LI, MAI e YE, 2000; MATTOSO, FERREIRA e CURVELO, 1997]. As fibras são rígidas, apresentam superior resistência em comparação às demais fibras naturais, além de boa durabilidade [SAPUAN et al., 2006]. 
As fibras de sisal são constituídas de 70-78\% de celulose, 10-13\% de hemicelulose, $7-11 \%$ de lignina, $2 \%$ de pectina e ceras e $0-1 \%$ de cinzas [MARTIN et al., 2009; LACERDA, 2007; MEGGIATO JUNIOR et al., 2007; MWAIKAMBO e ANSELL, 2002], sendo os três primeiros os grandes responsáveis pelas propriedades físicas das fibras.

A fibra de sisal beneficiada é destinada principalmente à indústria de cordoaria [para confecção de cordéis, cordas, tapetes, capachos e outros], mas também pode ser utilizada na fabricação de pasta celulósica, empregada na confecção do papel kraft e de outros tipos de papéis finos (AGOPYAN et al., 2005). O material de partida usado no presente estudo, para as reações de hidrólise que serão posteriormente discutidas, consistiu na polpa obtida via processo kraft.

\subsection{PROCESSO KRAFT}

Pode-se definir o processo de polpação como sendo o processo de separação dos componentes principais das fibras lignocelulósicas mediante a utilização de energia química e/ou mecânica. Os diversos processos de polpação podem ser classificados de acordo com seus rendimentos ou de acordo com o pH utilizado [ARAÚJO, 2004).

processo pioneiro de fabricação de papel foi o processo soda, originalmente patenteado em 1864. Atualmente poucas fábricas operam este processo, devido ao desenvolvimento do processo kraft por C. J. Dahl, que minimiza os danos às fibras da celulose, de forma a preservar sua uniformidade e resistência, além de permitir a recuperação de aproximadamente 99\% das substâncias químicas utilizadas durante o processo [ARAÚJO, 2004].

As principais vantagens do processo kraft sobre os demais são: grande flexibilidade com relação às fontes lignocelulósicas, ciclos de cozimento mais curtos e 
viabilidade econômica de recuperação do licor utilizado. Já as principais desvantagens correspondem ao alto custo de investimento na construção da fábrica, ao baixo rendimento de polpação e ao alto custo de branqueamento da polpa final.

Em suma, neste processo as fibras [ou cavacos, quando se trata de madeira] são aquecidas em um vaso de pressão [digestor] com licor de cozimento consistindo, principalmente, de uma solução aquosa de hidróxido de sódio e de sulfeto de sódio, além de outros sais de óxidos, em quantidades relativamente pequenas, sendo que o vapor desprendido durante a descarga é usado para aquecer a água destinada ao consumo da fábrica.

A recuperação dos reagentes constitui uma parte essencial do processo kraft. A função do sistema de recuperação não consiste, unicamente, em retornar os reagentes ao digestor com um mínimo de perda, mas também consiste em produzir vapor para diversas operações (tais como cozimento, branqueamento e secagem reduzindo os custos], licor de cozimento com composição adequada a sua reutilização, e eliminar parte dos efluentes com potencial poluidor.

No presente trabalho foi realizado um estudo da hidrólise de polpa de sisal. Esta fibra lignocelulósica, que possui aproximadamente 7-11\% de lignina [PAIVA e FROLLINI, 2006], foi deslignificada a partir de polpação kraft e branqueada, ambos processos conduzidos na empresa concedente da polpa.

Os processos de polpação são usados em indústrias ligadas a celulose e papel. No entanto, nas últimas décadas se observa a tendência destas indústrias gradualmente se transformarem em biorrefinarias. 


\subsection{CONCEITO DE BIORREFINARIA}

Pode-se considerar que o conceito de biorrefinaria, conforme entendido atualmente, surgiu na década de 90 [RESTOLHO et al., 2009].

Segundo definição encontrada em trabalho patrocinado pela Agência Internacional de Energia [IEA Bioenergy - Task 42 on Biorefineries], as biorrefinarias envolvem o "processamento sustentável da biomassa gerando um espectro de produtos comercializáveis e energia". Neste contexto, o termo sustentável deve ser entendido do ponto de vista econômico, social, impacto ambiental minimizado, substituição de combustíveis fósseis e envolvimento de ciclos fechados. A biomassa pode corresponder a madeira, produtos agrícolas, palhas, resíduos florestais, assim como biomassa de origem aquática. Os produtos envolvem tanto alimentos, ração, como produtos químicos, materiais, e a classificação como comercializável está vinculada tanto a um mercado já existente, como a um previsto para o futuro, tendo como base demandas de mercado e preços.

Neste contexto, as indústrias de papel e celulose, ao ampliarem processos e produtos, podem ser inseridas nas chamadas "biorrefinarias de matérias-primas lignocelulósicas" [Lignocellulosic Feedstock Biorefinery, LCF-BR], em que biomassa lignocelulósica é usada. Para biorrefinarias ligadas ao setor de papel e celulose, o termo "biorrefinaria florestal" é normalmente usado.

De acordo com o Laboratório Nacional de Energia Renovável [NREL] dos Estados Unidos da América [EUA], uma biorrefinaria é um complexo fabril que integra equipamentos e processos de conversão de biomassa para produzir combustíveis, energia, e insumos químicos. 
O conceito de refinaria aplica-se ao aproveitamento integral de matéria-prima abundante e de baixo custo, empregando-se tratamentos físicos e/ou químicos para a produção de produtos comerciais, de maior valor agregado. Pode-se, ainda, acrescentar que uma refinaria opera pela sucessão de diferentes etapas, iniciando-se por operações de fracionamento, visando à separação de diferentes substâncias, seguindo-se etapas de conversão destas substâncias em produtos de uso imediato ou a serem disponibilizados como matéria-prima para futuras transformações, pela indústria química [SCHAIDLE, MOLINE e SAVAGE, 2011; CURVELO, 2008].

O conceito de biorrefinaria é análogo às refinarias de petróleo, que produzem uma série de combustíveis e produtos químicos a partir do petróleo. A biomassa vegetal atende aos requisitos de abundância, custo e diversidade de produtos oriundos de seu processamento [STÖCKER, 2008]. Entretanto, diferenças marcantes separam a biomassa vegetal do petróleo. Dentre estas, destacam-se a maior complexidade química e estrutural da biomassa vegetal e o processo de obtenção da mesma. Enquanto o petróleo é matéria-prima não renovável, já estocada em reservas, a biomassa vegetal, para fins industriais, deve ser cultivada continuamente, sendo, portanto, renovável. Do ponto de vista físico, as reservas de petróleo fornecem matéria-prima nos estados líquido e gasoso, enquanto a matéria-prima vegetal encontra-se no estado sólido. Estas diferenças implicam em diferentes etapas nos processos de extração/colheita e de transporte aos centros de processamento [CURVELO, 2008].

As biorrefinarias industriais têm sido consideradas como o caminho mais promissor para a criação de novas indústrias focadas na preocupação ambiental [ORTS, HOLTMAN e SEIBER, 2008; HETTENHAUS, 2006]. Através da produção de diversos produtos, uma biorrefinaria pode se aproveitar da composição diversificada da biomassa, 
intermediando e maximizando seu valor agregado [HEININGEN, 2006]. Uma biorrefinaria pode, por exemplo, produzir ao mesmo tempo um ou vários produtos químicos de pequeno volume e alto valor agregado, e combustíveis de transporte de baixo valor agregado e grande volume, enquanto gera calor e eletricidade suficientes para manter seu funcionamento. Os produtos de alto valor agregado aumentam a rentabilidade, os grandes volumes de combustíveis de transporte vão de encontro às necessidades nacionais, e a produção de calor e eletricidade reduz custos e evita a emissão de gasesestufa.

A Figura 15 ilustra um diagrama de bloco do processo produtivo de uma biorrefinaria lignocelulósica integrada [Integrated Forest Biorefinery, IFBR].

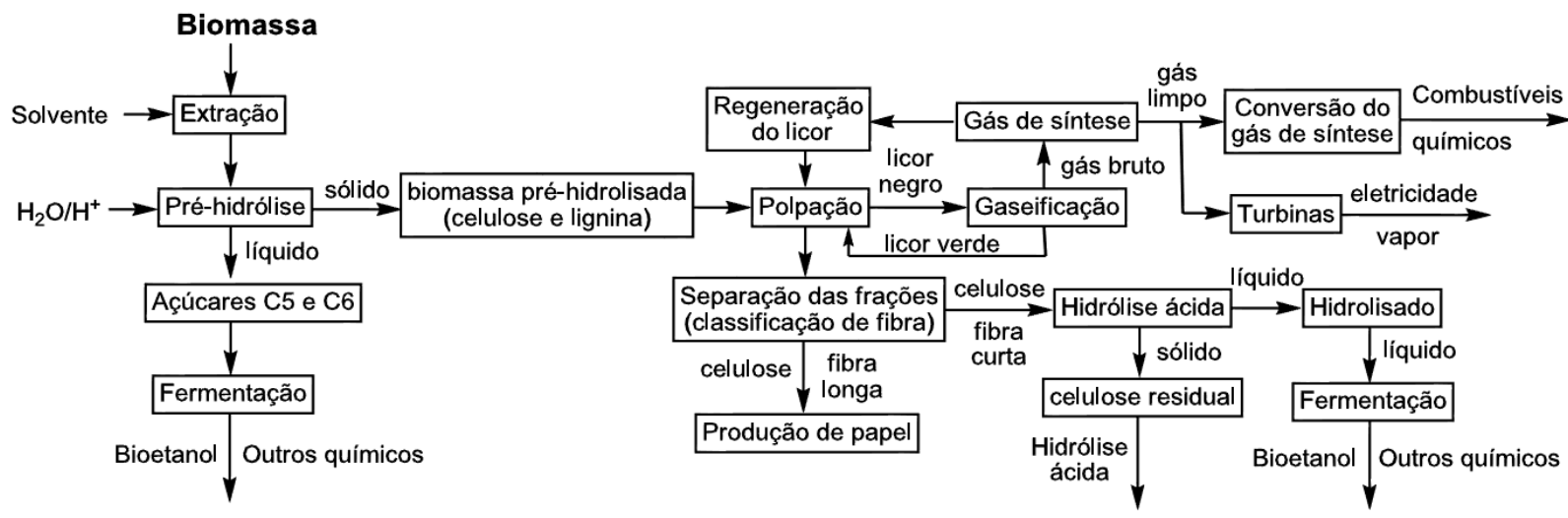

Figura 15 - Diagrama de bloco do processo de uma biorrefinaria lignocelulósica integrada [adaptado de HUANG et al., 2009].

Através deste digrama é possível perceber como o projeto da biorrefinaria pode ser facilmente integrado à indústria de papel e polpa celulósica, visto que os principais produtos [celulose e lignina] são produzidos em larga escala por esse tipo de indústria, que possui todo o conhecimento para modificar a tecnologia existente para uma biorrefinaria integrada [GURGEL, 2010; HUANG et al. 2009].

De uma forma geral, há uma forte tendência de que as biorrefinarias vão se desenvolver na forma de complexos industriais dispersos, capazes de revitalizar as 
áreas rurais. Em contraste com as refinarias convencionais, que correspondem necessariamente a plantas de dimensões muito grandes, as biorrefinarias irão provavelmente abranger toda uma gama de instalações de diferentes tamanhos. Idealmente, várias "bioindústrias" podem combinar seus fluxos de produtos a fim de atingir uma completa utilização de todos os componentes da biomassa: o resíduo de uma bioindústria (por exemplo, a lignina de uma indústria que produz etanol lignocelulósico] se torna matéria-prima para outras indústrias, dando origem ao que pode ser chamado de "sistema integrado bioindustrial" (KAPARAJU et al., 2009).

A sacarificação da celulose, tema principal do presente trabalho, é de importância fundamental em uma biorrefinaria, uma vez que esta reação abre caminhos para a produção de uma grande variedade de produtos químicos. 


\section{Capítulo}

\section{2}

\section{HIDRÓLISE DE POLPA DE SISAL: ESTUDO DA SACARIFICAÇÃO DE CELULOSE PARA PRODUC̣ÃO DE ETANOL}

\subsection{INTRODUÇÃO}

\subsubsection{SACARIFICAÇÃO DA CELULOSE}

O termo sacarificação representa a produção de açúcares simples a partir de polissacarídeos como amido, celulose, hemicelulose e pectina. Os principais métodos de sacarificação de celulose podem ser classificados em três categorias distintas: ácido diluído [concentração do ácido menor do que $5 \% \mathrm{~m} / \mathrm{v}$ ] ou concentrado [concentração do ácido maior do que $5 \% \mathrm{~m} / \mathrm{v}$ ] e enzimático. Outros métodos envolvem transformações termoquímicas [acima de $700^{\circ} \mathrm{C}$ ] e fluídos sub e supercríticos, que não correspondem ao escopo deste trabalho. 
A possibilidade de converter a celulose em açúcares simples se torna especialmente útil quando aliada à necessidade de se buscar fontes alternativas de energia, pois estes açúcares simples podem ser facilmente convertidos a etanol, justificando o crescente interesse em pesquisas objetivando a utilização de material lignocelulósico, normalmente resíduos agrícolas, na produção do chamado bioetanol.

Um grande número de métodos para a conversão de celulose em glicose vem sendo desenvolvido ao longo dos anos [CHO et al., 2011; SHIELDS e BOOPATHY, 2011; ARANTES e SADDLER, 2010; ZHU et al., 2009; TÁSIC et al., 2009; RODRIGUES e GUIRARDELLO, 2008; LU e MOSIER, 2008; XIANG, LEE e TORGET, 2004; BUSTOS et al., 2003; SASAKI et al., 1998; TOMME, WARREN, R.A.J.; GIKES, 1995). Os dois processos mais comumente utilizados envolvem celulases extraídas de fungos como Trichoderma sp. ou ácidos, como o sulfúrico, diluídos ou concentrados. Enzimas ainda possuem alto custo para serem aplicadas na produção de etanol combustivel a partir de biomassa. A catálise ácida é mais atraente neste sentido, embora os custos associados ao seu uso, i.e., corrosão e armazenamento, aumentem o custo final do processo. Ainda, o ácido pode degradar a glicose formada nas altas temperaturas requeridas para a hidrólise da celulose, quando soluções diluídas são usadas [MOSIER et al., 2001]. A degradação da glicose não apenas diminui a concentração dos açúcares fermentesciveis, como também forma produtos de degradação, como hidroximetilfurfural [HMF], ácido levulínico e ácido fórmico, que atuam como inibidores na posterior etapa de fermentação para a produção de etanol [LARSSON et al., 2009].

Observa-se atualmente uma tendência à combinação dos métodos ácido e enzimático, sendo um usado como agente de pré-tratamento da biomassa, e o outro como catalisador para a reação de sacarificação. Sindhu e colaboradores [SINDHU et 
al., 2011] avaliaram a viabilidade do uso dos ácidos sulfúrico ou clorídrico diluídos como agentes de pré-tratamento para o bagaço de cana-de-açúcar, seguido da reação de sacarificação por via enzimática. Os resultados mostraram que o prétratamento ácido foi de grande importância para eliminar hemiceluloses e lignina presentes na fibra, aumentando consideravelmente o rendimento da reação de hidrólise enzimática.

No presente trabalho, um estudo sobre a sacarificação da polpa de sisal foi desenvolvido empregando catálise ácida e enzimática. Para este fim, foram usados ácidos sulfúrico ou oxálico, em diferentes temperaturas e concentrações do ácido e, paralelamente, um complexo enzimático comercial [constituído de celulases e hemicelulases], também em diferentes condições, a fim de avaliar a influência destes parâmetros na eficiência do processo.

\subsubsection{1 Ácida}

Os processos de hidrólise ácida de celulose podem ser divididos em duas categorias distintas: aqueles realizados com soluções concentradas de ácido ou com soluções diluídas. O processo envolvendo soluções diluídas é o mais antigo, e envolve a utilização da biomassa celulósica suspensa na solução ácida $[0,1$ - 5\% [v/v]], normalmente sob pressão e altas temperaturas [de 180 a 215 C] (DE PAULA, 2009], para alcançar taxas aceitáveis de hidrólise à glicose em tempos razoavelmente curtos, devido à inacessibilidade dos cristalitos de celulose [SAEMAN, 1981]. Nos anos recentes, contudo, o tratamento de biomassa lignocelulósica com ácido sulfúrico diluído tem sido primeiramente usado como forma de pré-tratamento para hidrólise enzimática de celulose. A hidrólise de celulose baseada em ácido diluído tem sido pouco adotada desde que possui problemas técnicos inerentes. Esse processo tem o inconveniente dos 
açúcares serem decompostos sob condições severas necessárias para promover a hidrólise de celulose, ou seja, alta temperatura e baixo pH [XIANG, 2002].

método utilizando soluções concentradas de ácido envolve a biomassa celulósica suspensa na solução ácida [30 - 70\% [v/v]] e temperaturas mais baixas [de 25 a $120^{\circ} \mathrm{C}$ ] (DE PAULA, 2009). De acordo com Saeman [SAEMAN, 1981], ao contrário da hidrólise ácida diluída, a hidrólise empregando ácidos concentrados resulta em um intumescimento com consequente solubilização da celulose e insignificante destruição do carboidrato. 0 produto solúvel em água provindo de tal hidrólise primária é prontamente hidrolisado a glicose com alto rendimento. Portanto, em contraste ao processo ácido diluído o processo ácido concentrado pode gerar rendimentos maiores de glicose em baixas temperaturas e pressões, havendo a possibilidade do uso de reatores de baixo custo - desde que sejam feitos de materiais que não sofram corrosão, tais como reatores de fibra de vidro ou revestidos internamente por polímeros inertes ao ácido, como o teflon.

No entanto, concentrações mais altas de ácido podem levar a problemas como o pH da solução, que pode impedir a fermentação por micro-organismos. Neste sentido, estudos foram direcionados para que ácido e açúcares pudessem ser separados por membranas de troca iônica, além de o ácido ser recuperado e reconcentrado através de evaporadores de múltiplas etapas [XIANG et al., 2003]. Wu e colaboradores [WU et al., 2009] também utilizaram um tipo de argila ativada para separar os produtos da hidrólise da solução concentrada de ácido por adsorção na argila e posterior separação por filtração.

A utilização de membranas de troca iônica é feita, muitas vezes, com sucessivas trocas dos ácidos por amônia numa proporção de 1:1 e, assim, é possível separar os açúcares purificados para posterior fermentação, e o ácido para 
recuperação [HAMELINCK, HOOIJDONK e FAAIJ, 2005]. Quando foram inicialmente utilizadas, as membranas de troca iônica já alcançavam 80\% de eficiência na separação de ácidos. Processos de troca iônica sucessivos recuperam quase 97\% de todo o ácido e apenas 2\% dos açúcares são perdidos [HAMELINCK, HOOIJDONK e FAAIJ, 2005]. Também é importante salientar a necessidade do uso de equipamentos resistentes a corrosão, que pode acrescentar impurezas ao meio [ABASAEED, 1987].

Outra característica que envolve a hidrólise ácida de biomassa é a possibilidade de utilização de diversos ácidos, pois o processo é ácido-catalisado, em princípio necessita-se apenas de uma fonte de prótons no meio aquoso para que a reação ocorra. Neste caso, diversos estudos foram realizados envolvendo diferentes tipos de ácidos como $\mathrm{H}_{2} \mathrm{SO}_{4}, \mathrm{HCl}, \mathrm{H}_{3} \mathrm{PO}_{4}$, ácido fórmico entre outros [LENIHAN et al., 2010; TIAN et al., 2010; SUN et al., 2008; GÁMEZ et al., 2004; SIVERS e ZACCHI, 1995]. Marzialetti e colaboradores [MARZIALETTI et al., 2011] descreveram um processo de hidrólise de fibras de gramíneas utilizando ácido fórmico diluído como catalisador. Os resultados mostraram bom rendimento e baixa concentração de produtos de decomposição.

Embora exista uma vasta gama de ácidos que podem ser usados como fonte de prótons para a reação de hidrólise de celulose, aquele mais comumente usado é o sulfúrico, que é o único ácido poliprótico comum para o qual a primeira desprotonação é completa. A segunda desprotonação aumenta apenas ligeiramente a molaridade de $\mathrm{H}_{3} \mathrm{O}^{+}$[ATKINS e JONES, 2006), sendo $\mathrm{pKa}_{1}=-3$ e $\mathrm{pka}_{2}=1,92$ [BUDAVARI, 1996].

Apesar de não possuir grau de ionização tão alto quanto o do ácido sulfúrico [pKa $\mathrm{pK}_{1}=1,27$ e pKa $\mathrm{p}_{2}=4,28$ [BUDAVARI, 1996]], o ácido oxálico [ou ácido etanodióico] possui a grande vantagem de poder ser obtido a partir de fontes naturais, como a 
biomassa. Presente em muitas plantas e vegetais, notadamente das famílias Oxalis e Rumex, o ácido oxálico é também produto do metabolismo de muitos fungos. Algumas espécies de Penicillium e Aspergillus convertem açúcares em oxalato do cálcio com rendimentos de até 90\% [BUDAVARI, 1996]. A fermentação e oxidação com ácido nítrico de carboidratos são usadas na produção do ácido oxálico [GÜRÜ, BILGESÜ e PAMUK, 2001; SULLIVAN et al., 1983].

No presente trabalho foi realizado um estudo sobre a hidrólise de polpa de sisal usando ácido oxálico, por se tratar de ácido que pode ser obtido de fontes renováveis. Este estudo foi realizado paralelamente à hidrólise com ácido sulfúrico, para fins de comparação. As reações de hidrólise foram acompanhadas avaliando o licor [sobrenadante] e o material não hidrolisado ao longo do tempo.

\subsection{MECANISMO}

O mecanismo da reação de hidrólise ácida da celulose foi investigado durante muitos anos por diversos pesquisadores, e o principal mecanismo, confirmado através de vários estudos, é apresentado na Figura 16 [RINALDI e SCHÜTH, 2009]. 


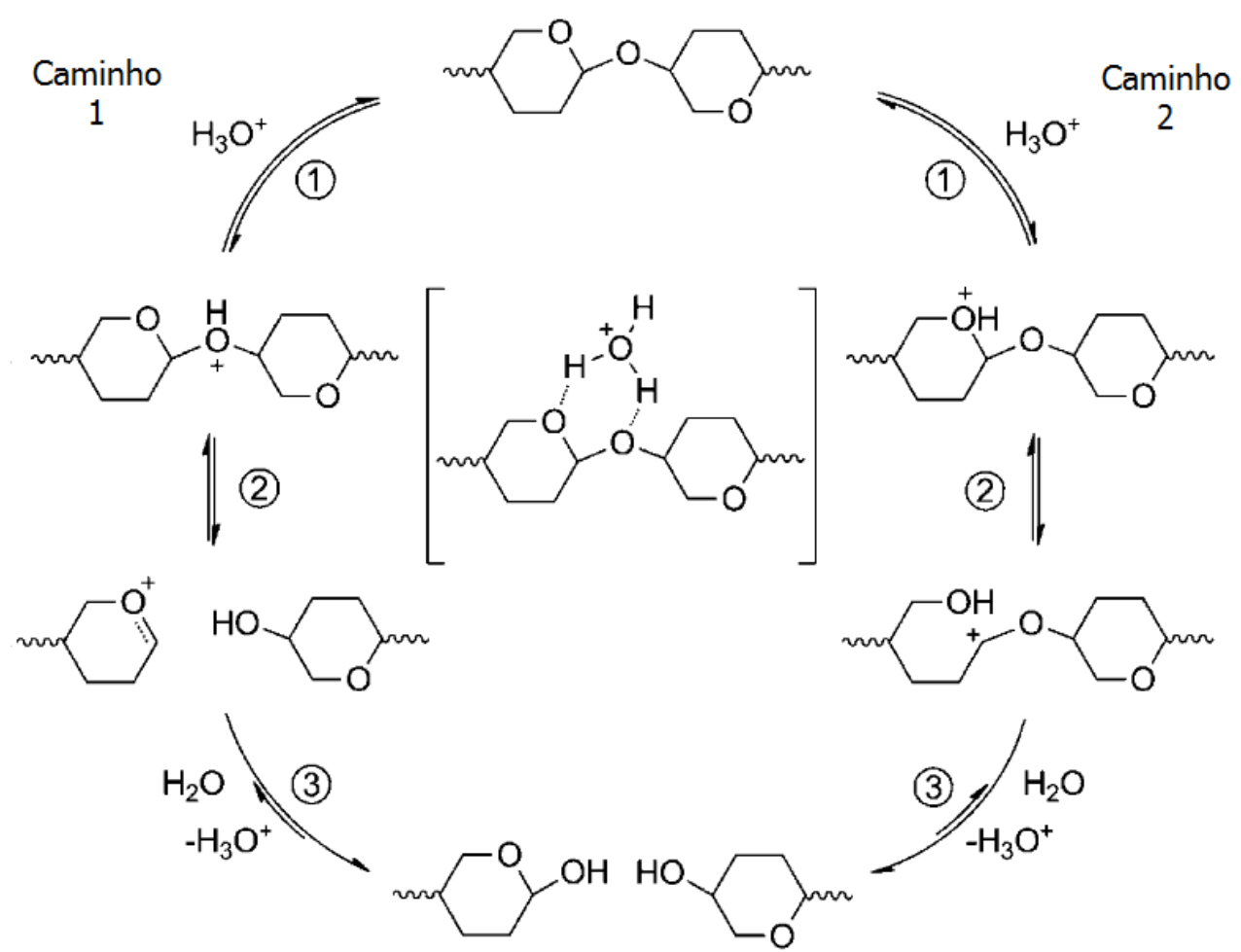

Figura 16 - Mecanismo de hidrólise ácida das ligações glicosídicas. Hidrogênios e grupos hidroxila foram omitidos [RINALDI e SCHÜTH 2009].

0 mecanismo de hidrólise ácida que leva à quebra das ligações glicosídicas ocorre em três etapas. A primeira etapa começa com um próton de um catalisador ácido que interage rapidamente com o oxigênio glicosídico que une as unidades de $\beta$ D-anidroglicose, formando o ácido conjugado [Figura 16]. A segunda etapa corresponde à quebra da ligação C-O do ácido conjugado com a formação de carbocátion. Tanto o carbocátion cíclico [caminho 1] como o não cíclico [caminho 2] estão propostos neste esquema. Em uma terceira etapa, um próton é liberado após uma rápida adição de água [XIANG, 2002]. 0 carbocátion intermediário é formado mais rapidamente no final da cadeia polissacarídica do que no meio, assim o rendimento de monossacarídeos, após hidrólise parcial, é maior do que o calculado com base em uma quebra aleatória das cadeias [FENGEL e WEGENER, 1984]. A hidrólise de hemiceluloses se dá por mecanismos similares, gerando os açúcares que a constituem, como por exemplo a xilose [DE PAULA, 2009]. 
Vale destacar que o curso geral da hidrólise sofre influências tanto do meio ácido reacional quanto das características da celulose. 0 meio hidrolisante pode influenciar a reação por: tipo, concentração e força do ácido, temperatura e pressão. Com relação à celulose, os fatores importantes são: [1] se a reação ocorre em fase homogênea, ou em fase heterogênea, e [2] a acessibilidade, no caso de hidrólise heterogênea [GURGEL, 2010].

Os ácidos são caracterizados pelos seus valores de força ácida [pka], que influenciam a taxa geral de hidrólise das ligações glicosídicas. Os parâmetros adicionais são a temperatura e a pressão: geralmente, um aumento da temperatura e da pressão aumenta a velocidade de hidrólise em alguma extensão, dependendo das características do ácido em questão [GURGEL, 2010].

Altos rendimentos de glicose e altas taxas de reação não são alcançados somente pela remoção de lignina e hemiceluloses da matéria-prima lignocelulósica. Mesmo materiais celulósicos que nunca tenham tido lignina e hemiceluloses associados a eles, por exemplo, o algodão, são difíceis de hidrolisar sem prétratamento [COWLING e KIRK, 1976; MILLETT, BAKER e SATTER, 1976]. Esta dificuldade de hidrolisar a celulose é também devido à presença de regiões não cristalinas e cristalinas, sendo que processos de hidrólise ácida que atinjam a celulose compreendida nessas duas regiões são necessários para que a reação ocorra [GURGEL, 2010]. As condições requeridas para intumescer as regiões não cristalinas são relativamente brandas, mas processos drásticos são requeridos para afetar as regiões cristalinas. Isto consiste no maior problema para a hidrólise ácida, ou seja, a celulose não cristalina é rapidamente hidrolisada à glicose, e essa a produtos de decomposição, enquanto a celulose presente nos domínios cristalinos leva um tempo maior para ser convertida a uma forma prontamente hidrolisada, 
portanto, processos seletivos são necessários a fim de aumentar o rendimento de glicose [MILLETT, BAKER e SATTER, 1976].

Além da produção de açúcares como etapa da produção do bioetanol, a possibilidade de produção de materiais também foi considerada no presente trabalho. Durante o processo de hidrólise ácida, variações dos valores de cristalinidade e massa molar média do material não hidrolisado foram acompanhadas.

\subsection{CINÉTICA}

Saeman [SAEMAN,1945] propôs um modelo simples de duas etapas para descrever a formação de glicose pela quebra de ligações glicosídicas da celulose de madeira por catálise ácida [DE PAULA, 2009]. Para isso, assumiu uma pseudoprimeira ordem de reação, considerando as reações como irreversíveis, além de também considerar uma pseudo-homogeneidade do meio, ou seja, supondo que toda celulose [região cristalina e não cristalina] tenha a mesma reatividade. 0 esquema a seguir mostra as etapas que são consideradas neste modelo.

$$
A_{\text {celulose }} \stackrel{k_{1}}{\longrightarrow} B_{\text {glicose }} \stackrel{k_{2}}{\longrightarrow} C_{\text {prod.decomp. }}
$$

Sendo $k_{1}$ a constante de hidrólise da celulose e $k_{2}$ a constante de decomposição da glicose formada. A taxa de decomposição unimolecular da celulose é:

$$
\frac{d[A]}{d t}=-k_{1} A
$$

O intermediário B [glicose] é formado pela degradação de A [celulose] em uma taxa de $k_{1}[A]$, porém é degradado a $C$ segundo $k_{2}[B]$ : 


$$
\frac{d[B]}{d t}=k_{1} A-k_{2}[B]
$$

Considerando um único reagente inicial $[A=$ celulose $]$ e que $[A]_{\circ}$ é a concentração inicial de celulose, se tem, pela consideração de primeira ordem de reação que:

$$
[A]=[A]_{0} e^{-k_{1} t}
$$

Assim quando esta equação é substituída em [3], após rearranjos serem feitos chega-se a:

$$
\frac{d[B]}{d t}+k_{2}[B]=k_{1}[A]_{0} e^{-k_{1} t}
$$

Integrando e considerando $[\mathrm{B}]_{0}=[\text { glicose }]_{0}=0$, tem-se:

$$
[B]=\frac{k_{1}}{k_{2}-k_{1}}\left(e^{-k_{1} t}-e^{-k_{2} t}\right)[A]_{0}
$$

Também chamada de Modelo de Saeman para hidrólise ácida de celulose.

No presente trabalho, foram realizadas reações de hidrólise ácida de polpa de sisal utilizando ácido sulfúrico ou ácido oxálico como catalisador.

\subsubsection{Enzimática}

A hidrólise enzimática de celulose a glicose é realizada por enzimas chamadas celulases, em uma catálise altamente específica. A reação é geralmente conduzida em condições brandas, i.e., pH entre 4 e 5 e temperaturas entre 40 e $50^{\circ} \mathrm{C}$. Por estes motivos, inexistem problemas associados à corrosão de reatores, os custos de energia elétrica são menores e a toxicidade dos reagentes é muito baixa, o que tornam a hidrólise enzimática um processo atrativo e vantajoso para a sacarificação da biomassa. 
A sacarificação enzimática da celulose é geralmente descrita como um sistema heterogêneo no qual celulases em solução reagem com a celulose insolúvel, contendo regiões altamente organizadas [regiões cristalinas] e outras com grau de organização intermediário [regiões não cristalinas] [ARANTES e SADDLER, 2010).

A hidrólise enzimática da celulose consiste na utilização de enzimas que são específicas, produzidas tanto por bactérias como por fungos [BEGUIN e AUBERT, 1994]. A especificidade das enzimas faz com que os produtos da hidrólise sejam essencialmente glicose e alguns oligômeros, como a celobiose. Esta é a grande vantagem deste método, pois não ocorre a formação de produtos de decomposição dos açúcares. O mecanismo clássico para esta reação envolve a ação simultânea de endoglicanases e celobiohidrolases, que hidrolisam a celulose no estado sólido, gerando moléculas de glicose solúveis [LYND et al., 2002; ZHANG e LYND, 2004).

A via enzimática possui baixa eficiência, devido a uma série de razões. Dentre elas, os fatores que incluem a adsorção das enzimas no substrato e a dificuldade em ocorrer interações enzima-substrato devido à heterogeneidade da reação [KUMAR e WYMAN, 2009]. Após a adsorção, a celulase realiza um grande número de sucessivas modificações catalíticas para se dessorver da superfície do substrato [celulose] e catalisar a hidrólise em outras moléculas [LI et al., 2005].

Além disso, são também necessárias condições ótimas de reação como pH e temperatura, atividade enzimática e condição do substrato [no caso a biomassa] que não deve conter interferentes [lignina e hemiceluloses], e a presença de oligômeros, formados no meio, como a celobiose que em alguns casos pode inibir a ação da celulase [CHEUNG e ANDERSON, 1997]. Os altos tempos de reação também podem ser considerados como fator importante da utilização da via enzimática. Além de todos estes fatores, as enzimas fabricadas comercialmente ainda possuem custo 
elevado para a viabilização do processo de obtenção de etanol em larga escala, e a redução destes custos vem despertando interesse de empresas e centros de pesquisa nos últimos anos.

Em 2000, a Genencor Internacional, através do Laboratório Nacional de Energias Renováveis (National Renewable Energy Laboratory, NREL), selou um contrato com o Departamento de Energia dos Estados Unidos [US Department of Energy, DOE], a fim de reduzir em dez vezes os custos das celulases por galão de etanol produzido. Este objetivo foi atingido em três anos, e o programa foi estendido visando reduzir os custos em um fator de 20 [DEAN et al., 2006; NREL, 2000]. A Figura 17 ilustra a evolução dos custos do complexo enzimático [Genencor], do ano 2000 até o ano de 2008.

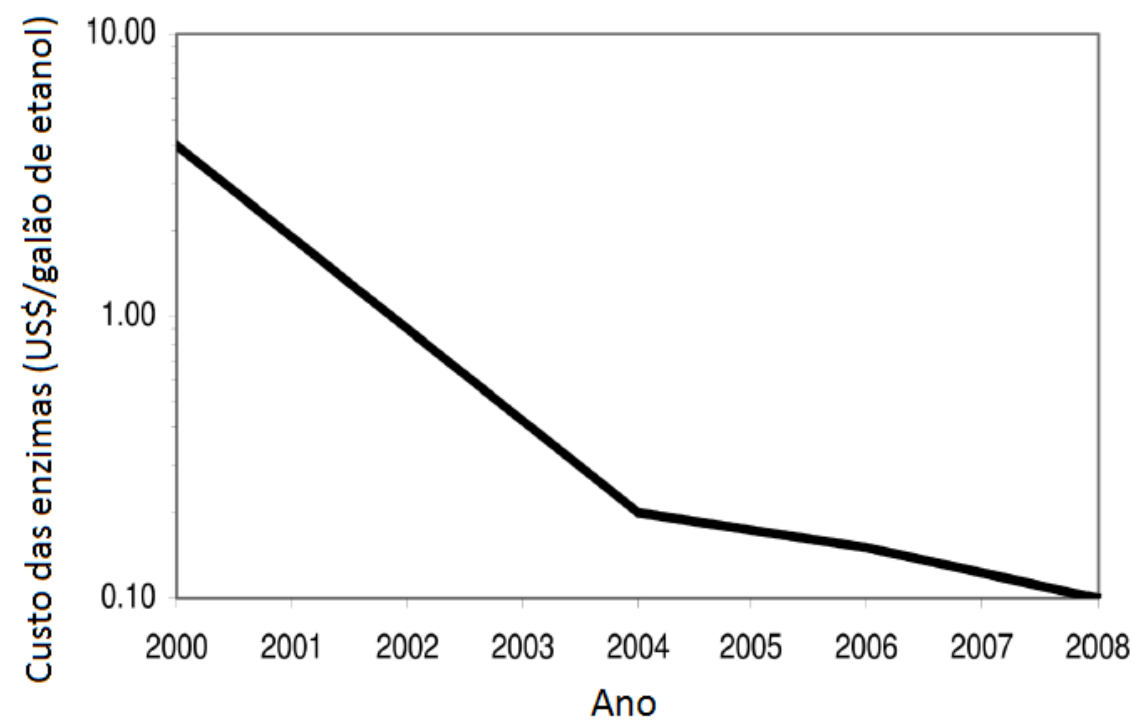

Figura 17 - Evolução dos custos dos complexos enzimáticos [celulases] ao longo dos anos [DEAN et al., 2006].

\subsection{MECANISMO}

A hidrólise enzimática de celulose e hemiceluloses pode ser conduzida por enzimas [celulases e hemicelulases] altamente específicas. Este grupo comporta pelo menos 15 famílias de proteínas e algumas subfamílias [RABINOVICH, MELNIK e BOLOBOBA, 2002). Como descrito anteriormente, a reação de hidrólise enzimática de 
celulose consiste na adsorção da celulase na superfície da celulose, na biodegradação da celulose a açúcares fermentescíveis, e na dessorção da celulase. A degradação da celulose a glicose é geralmente alcançada pela ação sinérgica de pelo menos três classes de enzimas: endoglucanases, exoglucanases e $\beta$-glicosidades. A este grupo de enzimas é dado o nome de celulases [WYMAN, 1996].

As endoglucanases atacam as regiões não cristalinas das fibras de celulose, criando "términos de cadeias" [ou grupos redutores]. As exog/ucanases posteriormente degradam as cadeias através destes términos, removendo unidades de celobiose [dímeros de glicose]. A celobiose é, então, convertida a glicose através das $\beta$-glicosidases [Figura 18]. 


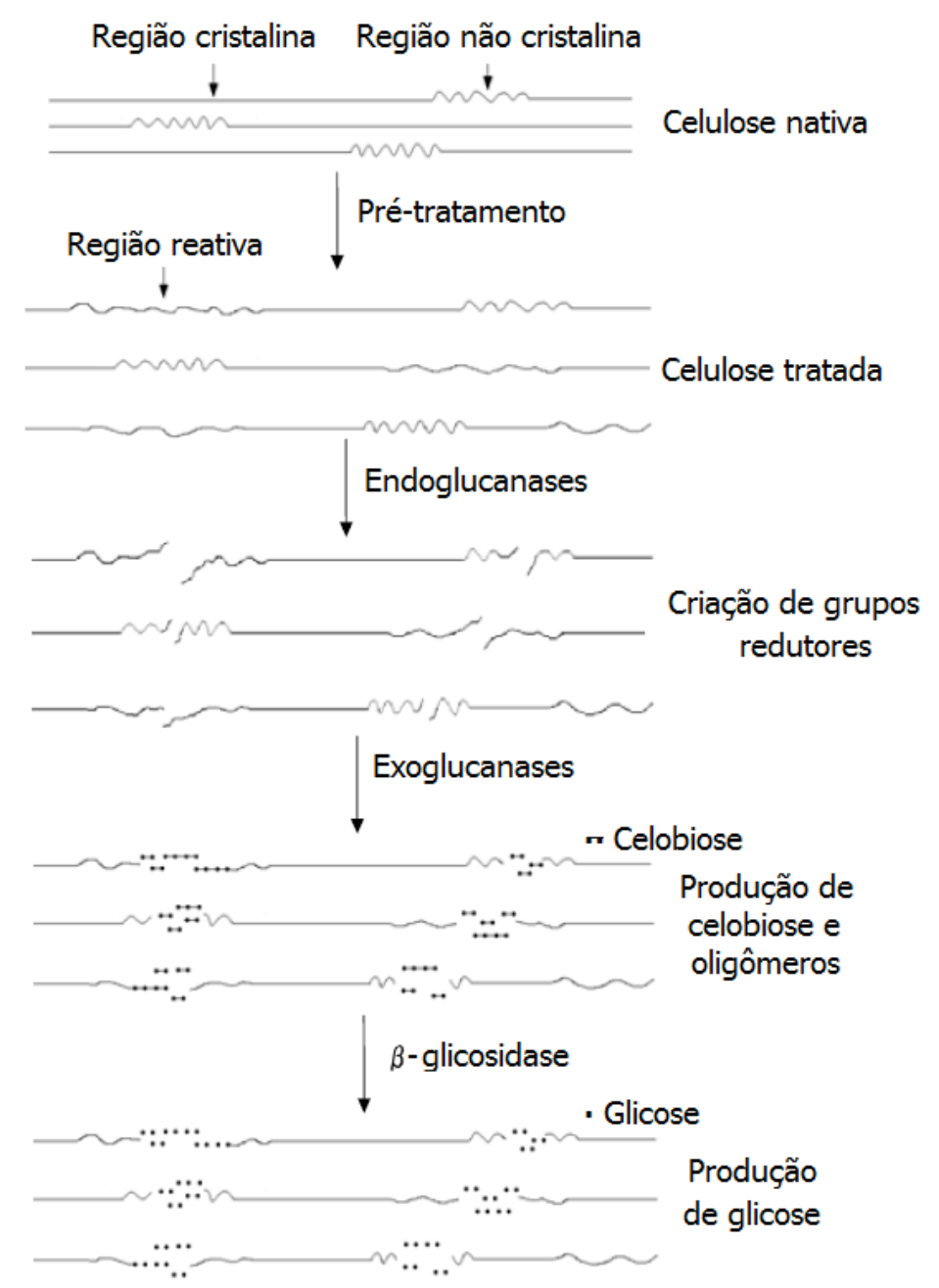

Figura 18 - Representação esquemática da conversão de celulose a glicose por um mecanismo de hidrólise enzimática. [Adaptado de TAHERZADEH e KARIMI [2007]).

A $\beta$-glicosidase não é uma celulase, mas sua ação é muito importante para a completa despolimerização da celulose a glicose. Uma vez que as hemiceluloses contêm diferentes unidades de açúcares, são mais complexas e envolvem, entre outras, endo-1,4$\beta$-D-xilanases, $\quad$ exo-1,4- $\beta$-D-xilosidases, $\quad$ endo-1,4- $\beta$-D-manases, $\quad \beta$-manosidades, acetilxilanesterases, $\alpha$-glicuronidases, $\alpha$-L-arabinofuranosidades e $\alpha$-galactosidades [JORGENSEN, KUTTER e OLSSON, 2003]. Várias espécies de bactérias como Clostridium, Cellumonas, Thermomonospora, Bacillus, Bacteriodes, Ruminococcus, Erwinia, Acetovibrio, Microbispora e Estreptomyces, e fungos como Tricoderma, Penicillium, Fusarium, Phanerochaete, Humicola e Schizophillum spp., são capazes de produzir 
celulases e hemicelulases [RABINOVICH, MELNIK e BOLOBOBA, 2002; SUN e CHENG, 2002]. Entre as celulases produzidas de diferentes microorganismos, aquelas obtidas de Trichoderma reesei e T. viride são as mais amplamente estudadas e melhor caracterizadas. Entre as muitas vantagens das celulases obtidas deste gênero de fungos, se destacam sua resistência frente a inibidores químicos e estabilidade no meio reacional. Entretanto, estas celulases apresentam a desvantagem da baixa atividade das $\beta$ glicosidases. Por outro lado, fungos do gênero Aspergilli são ótimos produtores de $\beta$ glicosidases. Em muitos casos, as celulases de Trichoderma são suplementadas com $\beta$ glicosidases, mostrando boa melhora na produção de glicose [ITOH et al., 2003; HARI KRISHNA e CHOWDARY, 2001; ORTEGA, BUSTO e PEREZ-MATEOS, 2001; TENGBORG, GALBE e ZACCHI, 2001; WYMAN, 1996]

A atividade de cada enzima em um complexo enzimático depende da fonte da qual cada enzima foi extraída [COUGHLAN e LJUNGDAHL, 1988]. As propriedades de sacarificação de uma dada celulase é geralmente estudada em termos de análises cinéticas, usadas para comparar a capacidade de sistemas enzimáticos provenientes de diferentes fontes, frente a hidrolise de celulose [SADDLER et al., 1986], bem como a suscetibilidade relativa da enzima frente a diferentes substratos de celulose [PARISI, 1989]. Estudos cinéticos também são usados para avaliar o potencial mecanismo das celulases [BELDMAN et al., 1985; 1988] e para desenvolver modelos cinéticos que podem ser usados para prever a taxa de sacarificação de um composto em particular [GUSAKOV, SINITSYN e KLYOSOV, 1985; MATSUMO et al., 1984]. Os estudos geralmente resultam em modelos mecanísticos distintos, que diferem quanto a suposições feitas com relação às celulases, à complexidade estrutural do substrato e à estabilidade das enzimas. Embora muitos estudos cinéticos já tenham sido apresentados, o mecanismo completo da ação de celulases frente a hidrolise ainda é desconhecido. 
O sinergismo entre os componentes individuais de um complexo enzimático de celulases agindo sobre a celulose insolúvel é um fator complicador para o estudo do mecanismo de ação das celulases. De fato, a adição de uma mistura de dois ou mais componentes hidrolisantes é maior que a soma da ação de cada componente individualmente. 0 maior problema em estudar este fenômeno é que o sinergismo afeta variáveis que dependem de inúmeros fatores envolvendo celulases e substrato [ORTEGA, BUSTO e PEREZ-MATEOS, 2001].

No presente trabalho, foi realizado um breve estudo sobre reações de hidrólise enzimática de celulose, utilizando polpa de sisal como substrato, cujo principal objetivo foi avaliar a influência de diferentes pré-tratamentos da polpa, no teor de açúcares produzido pelas enzimas. 


\subsection{EXPERIMENTAL}

\subsection{MATERIAIS}

A polpa utilizada em todas as etapas do trabalho foi a de sisal, gentilmente cedida pela empresa Lwarcell [Lençóis Paulista, SP] onde a fibra lignocelulósica passou pelo processo de polpação [ou deslignificação] do tipo kraft e sequência de branqueamento do tipo ECF [Elemental Chlorine Free]. Este processo resultou em uma polpa com alvura ISO de $86 \%$, comprimento e espessura médios de, respectivamente, 2,9 mm e 18,4 $\mu \mathrm{m}$. teor de lignina Klason foi determinado com o uso da norma TAPPI T222-om02, e a presença de lignina insolúvel não foi detectada. Todas as amostras de polpa de celulose foram trituradas em moinho Marconi [MA048] e secas em estufa de circulação a $105^{\circ} \mathrm{C}$ por $4 \mathrm{~h}$, antes de serem utilizadas.

Como reagentes e solventes foram utilizados:

- Ácido sulfúrico PA 95-98\% [Qhemis] e ácido oxálico diidratado [Cromato], nas etapas de hidrólise ácida da polpa celulósica;

- Etilenodiamina cúprica [Cuen] 2\%, [Qeel], na preparação de soluções de celulose para análises viscosimétricas;

- Hidróxido de sódio em lentilhas [Qhemis], no processo de mercerização e teor de $\alpha$-celulose;

- Ácido acético glacial [Mallinckrodt], na determinação do teor de $\alpha$-celulose;

- Citrato de sódio e ácido cítrico [Qhemis] para a preparação de tampão citrato, usado nas reações de hidrólise enzimática;

- Complexo enzimático Accellerase 1500 [Genencor], usado nas reações de hidrólise enzimática; 
- Os reagentes utilizados na análise dos hidrolisados por cromatografia líquida de alta eficiência [CLAE] foram: ácido sulfúrico $\left[\mathrm{H}_{2} \mathrm{SO}_{4}\right.$, Merck Chemicals], acetonitrila [Tedia] e ácido acético glacial [Merck Chemicals]. Os padrões utilizados foram celobiose, D-glicose [Sigma-Aldrich], D-xilose [Sigma-Aldrich], Larabinose [Sigma-Aldrich], ácido acético [49-51\%, Sigma-Aldrich], ácido fórmico [49-51\%, Sigma-Aldrich], 5-hidroximetil-2-furfuraldeído [HMF, SigmaAldrich] e 2-furfuraldeído [furfural, Sigma-Aldrich], todos de grau cromatográfico.

\subsubsection{METODOS}

\subsubsection{Caracterização da polpa de partida}

2.2.2.1.1 Teor de $\alpha$-celulose e hemiceluloses. A fração de amostra insolúvel em solução de $\mathrm{NaOH}$ 17,5\% correspondente à celulose isenta de hemicelulose, é chamada $\alpha$-celulose [BROWNING, 1967]. O procedimento consiste em adicionar 1,0 g de amostra a $10 \mathrm{~mL}$ de solução $17,5 \%$ de $\mathrm{NaOH}$, deixada em repouso por 8 min a temperatura ambiente. Após este período, são adicionados mais $10 \mathrm{~mL}$ da solução alcalina, misturando e deixando em repouso por mais 20 min. A suspensão é lavada com 40 mL de água e filtrada a vácuo em cadinho de porosidade média [40 a 100 m]. Após a filtração, o resíduo é lavado com solução de ácido acético diluído para neutralizar a base residual. 0 cadinho é levado à estufa a vácuo a $60^{\circ} \mathrm{C}$ por $4 \mathrm{~h}$ e pesado. A diferença entre a massa inicial e a final é equivalente à massa de $\alpha$-celulose na polpa.

O teor de hemiceluloses é dado pela diferença entre a massa total menos a massa de $\alpha$-celulose encontrada na amostra de polpa celulósica. Dependendo da fonte e do processo utilizados para isolamento de celulose, diferentes porcentagens de hemicelulose [e mesmo de lignina] podem estar presentes, o que pode influir desde 
agregação em solução, até na reatividade desta macromolécula [tanto em meio homogêneo como heterogêneo]. Assim, é importante o conhecimento do teor de $\alpha$ celulose.

2.2.2.1.2 Determinação da massa molar média por viscosimetria. 0 estudo viscosimétrico de polímeros em solução avalia o comportamento de fluxo das cadeias poliméricas como consequência de uma tensão de cisalhamento.

Os valores de massa molar média $\left[\mathrm{MM}_{\text {vis }}\right.$ e grau de polimerização médio [GP] podem ser obtidos através do método viscosimétrico, baseado na resistência ao fluxo de solução de celulose através de um capilar. A celulose isolada de fontes nativas é sempre polidispersa, isto é, consiste de uma mistura de macromoléculas com comprimentos de cadeia que diferem entre si [KLEMM et al., 1998]. Portanto, quando se fala em grau de polimerização ou massa molar para certa amostra, refere-se, na verdade, ao valor médio.

Para a celulose, o grau médio de polimerização representa o número de unidades de $\beta$-D-glicose presentes nas cadeias. A massa molar média pode variar dependendo da fonte da qual se extraiu o polissacarídeo (RAMOS et al., 2005). Pela lei de Hagen-Poiseuille [COLLINS et al., 1973], o coeficiente de viscosidade de um líquido através de um capilar é:

$$
\eta=\frac{\pi \times r^{4} \times t \times P}{8 V L}
$$

onde $\mathrm{P}$ é a pressão hidrostática sobre o líquido, $V$ é o volume do líquido, t o tempo em que o líquido flui através do capilar de raio $r$ e de comprimento $L$.

Ainda, $\mathrm{P}=\mathrm{h} \rho \mathrm{g} ;$ com $\mathrm{h}$ = altura da coluna de líquido, $\rho=$ densidade do líquido e g = aceleração da gravidade. 
A partir da lei de Hagen-Poiseuille aplicada ao líquido de viscosidade desconhecida e ao líquido padrão, obtém-se a seguinte equação, que permite determinar a viscosidade relativa da solução:

$$
\eta_{\text {rel }}=\frac{\eta_{1}}{\eta_{0}}=\frac{\rho_{1} \times t_{1}}{\rho_{0} \times t_{0}}
$$

Sendo que $\eta_{1}$ e $\eta_{0}$ correspondem às viscosidades da solução e do solvente, $\rho_{1}$ e $\rho_{0}$ às densidades da solução e do solvente, e $t_{1}$ e $t_{0}$ aos tempos de escoamento da solução e do solvente, respectivamente.

Para soluções diluídas, como as usadas no presente trabalho, em que as densidades do solvente e da solução são aproximadamente iguais, a viscosidade relativa, $\eta_{\text {rel }}$ corresponde aproximadamente à razão entre o tempo de escoamento da solução de polímero e o tempo de escoamento do solvente [MANO, 1985]:

$$
\eta_{r e l}=\frac{\eta_{1}}{\eta_{0}} \cong \frac{t_{1}}{t_{0}}
$$

Sendo: $\eta_{1}=$ viscosidade da solução; $\mathrm{t}_{1}=$ tempo de escoamento da solução; $\eta_{0}=$ viscosidade do solvente; $t_{0}=$ tempo de escoamento do solvente.

Através da equação de Martin, o valor de viscosidade intrínseca é calculado partindo-se do valor obtido para viscosidade relativa [IPT, 1996]:

$$
\log \frac{\eta_{s p}}{c}=\log [\eta]+k \times[\eta] \times c
$$

em que c é a concentração da solução do polímero; $\eta_{s p}$ é a viscosidade específica, igual a $\left[\eta_{\text {rel }}-1\right.$ ]; [n] é a viscosidade intrínseca; k é a constante empírica [para o sistema celulose/Cuen, $k=0,13]$. 
O grau de polimerização pode ser obtido a partir da viscosidade intrínseca, com o auxílio da seguinte equação [BILLMEYER JUNIOR, 1984]:

$$
G P^{0,905}=0,75[\eta]
$$

Sabendo que a massa molar da anidroglicose é $162 \mathrm{gmol}^{-1}$, tem-se, portanto que 162 x GP leva à massa molar média viscosimétrica da celulose:

$$
M M_{v i s}=162 \times G P
$$

No presente trabalho, o método viscosimétrico foi utilizado para a determinação da massa molar média das celuloses de partida e residuais [não reagidas durante as reações de hidrólise].

Para isso, foram feitas determinações do tempo de escoamento utilizado um viscosímetro capilar de vidro [do tipo Ubbelohde, $\mathrm{f}=0,63 \mathrm{~mm}$ ], AVS -350 da marca SchottGeräte, a $25^{\circ} \mathrm{C}$, e o sistema de solventes Cuen/água [1:1]. Assim, mediu-se o tempo de escoamento do solvente e, em seguida, o tempo de escoamento de uma solução de celulose $0,004 \mathrm{gmL}^{-1}$.

As medidas foram feitas em triplicata. A partir dos valores dos tempos de escoamento, pode-se calcular o grau de polimerização e a massa molar média viscosimétrica da celulose [Equações 11 e 12].

2.2.2.1.3 Determinação do índice de cristalinidade por difração de raios X. 0 grau ou índice de cristalinidade dos polímeros $\left[\mathrm{I}_{\mathrm{c}}\right]$ expressa a relação entre as porções cristalina e não cristalina do material, e pode ser avaliado por difração de raios $X$, que corresponde a uma das principais técnicas de caracterização microestrutural de materiais cristalinos, encontrando aplicações em diversos campos do conhecimento. 
Este método está fundamentado no fato de que os comprimentos de onda destes raios são comparáveis às distâncias interatômicas dos cristais, havendo a possibilidade de ocorrer interações e consequentes efeitos de interferência. Quando a estrutura é ordenada, como é o caso das regiões cristalinas dos materiais, as interferências são acentuadas, e pode-se distinguir estas estruturas das desordenadas, pois a periodicidade do cristal faz com que haja planos de átomos separados por uma distância fixa nas diferentes direções do espaço.

Ao atingirem um material, os raios $X$ podem ser espalhados elasticamente, sem perda de energia pelos elétrons de um átomo [dispersão ou espalhamento coerente]. Após a colisão com o elétron, o fóton de raios $X$ muda sua trajetória, mantendo, porém, a mesma fase e energia do fóton incidente. Se os átomos que geram este espalhamento estiverem arranjados de maneira sistemática, como em uma estrutura cristalina, apresentando entre eles distâncias próximas ao comprimento de onda da radiação incidente, pode-se verificar que as relações de fase entre os espalhamentos tornam-se periódicas e que efeitos de difração de raios X podem ser observados em vários ângulos.

Considerando-se dois ou mais planos de uma estrutura cristalina, as condições para que ocorra a difração de raios X [interferência construtiva ou numa mesma fase] vão depender da diferença de caminho percorrida pelos raios X e o comprimento de onda da radiação incidente. Esta condição é expressa pela Lei de Bragg $(n \lambda=2 d \operatorname{sen} \theta$ ], onde $\mathrm{n}$ é um número inteiro [ordem de difração], $\lambda$ é o comprimento de onda da radiação incidente, d é a distância interplanar para o conjunto de planos hkl [índice de Miller, onde h, k e I são inteiros com maior divisor comum igual a 1] da estrutura cristalina e $\theta$ é medido entre o feixe incidente e os planos cristalinos (Figura 19]. 


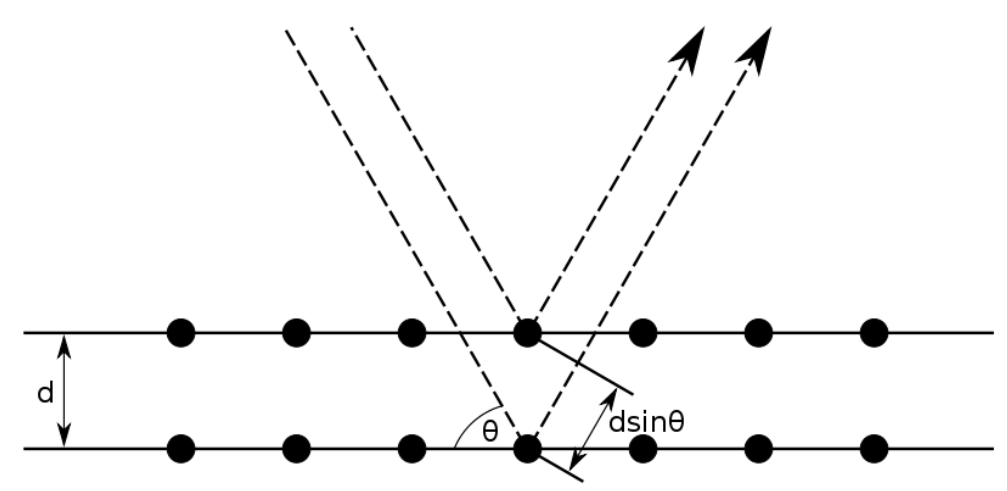

Figura 19 - Representação esquemática da Lei de Bragg.

A intensidade difratada é dependente do número de elétrons no átomo - entre outros fatores. Adicionalmente, os átomos são distribuídos no espaço de tal forma que os vários planos de uma estrutura cristalina possuem diferentes densidades de átomos ou elétrons, fazendo com que as intensidades difratadas sejam, por consequência, distintas para os diversos planos cristalinos.

A difração de raios $X$ foi usada no presente trabalho, pois se trata de uma técnica que permite avaliar as características estruturais do material celulósico, já que é possível observar a presença de picos característicos referentes aos planos cristalográficos dos retículos cristalinos presentes.

Foram analisadas amostras de polpa celulósica previamente seca em estufa de circulação a $105^{\circ} \mathrm{C}$ por $4 \mathrm{~h}$. Para a determinação do índice de cristalinidade foi utilizado um Difratômetro Universal de raios X modelo URD-6, CARL ZEISS JENA, à potência 40 $\mathrm{kV} / 20 \mathrm{~mA}$ e $\lambda[$ Cuk $\alpha]=1,5406 \AA$.

É possível observar na Figura 20, que mostra um difratograma típico de polpa celulósica de sisal que não passou por tratamento prévio [celulose I], a presença de picos característicos, referentes aos planos cristalográficos dos retículos cristalinos presentes. 


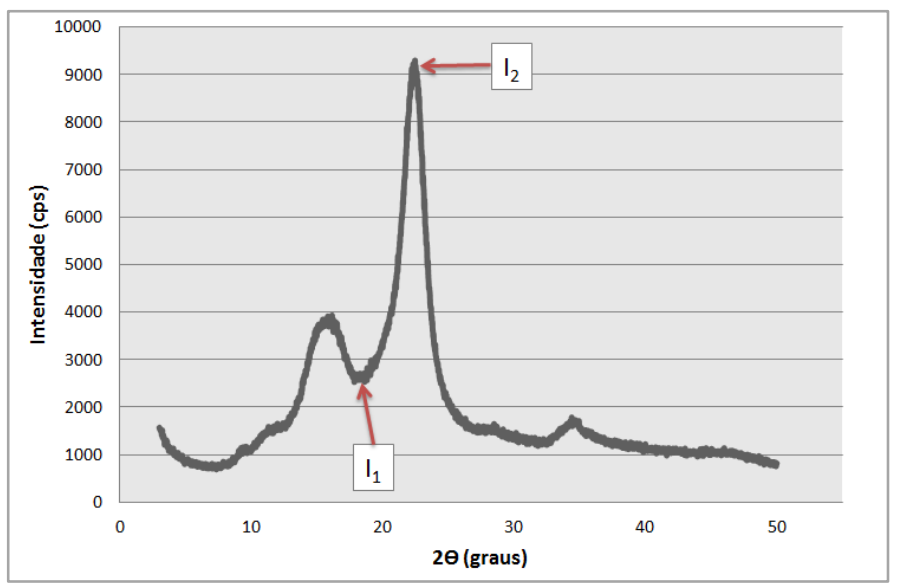

Figura 20 - Difratograma típico de polpa de celulose de sisal [sem tratamento prévio].

O índice de cristalinidade pode ser calculado utilizando-se a equação descrita por Buschle-Diller e Zeronian [BUSCHLE-DILLER e ZERONIAN, 1992].

$$
I_{c}=1-\frac{I_{1}}{I_{2}}
$$

Sendo que $\mathrm{I}_{1}$ corresponde ao valor da linha base do difratograma $\left[2 \theta\right.$ entre $18^{\circ} \mathrm{e}$ $19^{\circ}$ para a celulose nativa - celulose I; $2 \theta$ entre $13^{\circ}$ e $15^{\circ}$ para celulose previamente mercerizada - celulose $\|$, conforme descrito no ítem 1.1.1.6], referente à parte nãocristalina da celulose, e l é o valor do pico de difração $\left[2 \theta\right.$ entre $22^{\circ}$ e $23^{\circ}$ para a celulose nativa; $2 \theta$ entre $18^{\circ}$ e $22^{\circ}$ para celulose previamente mercerizada), referente à parte cristalina [Figura 21].

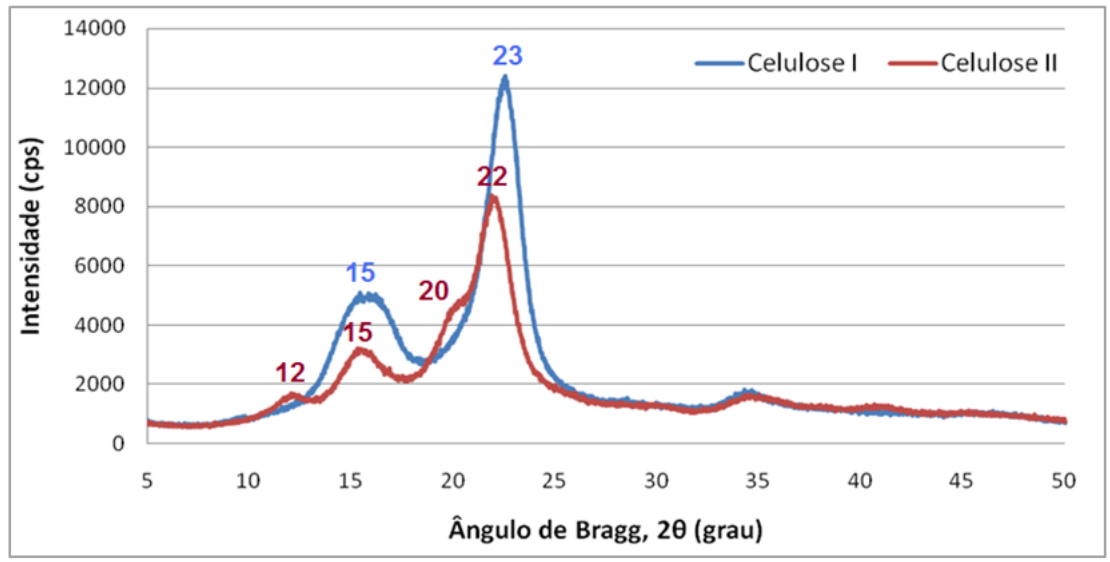

Figura 21 - Difratogramas de raios X correspondentes às celuloses I e II. 
Considerando a curva de intensidade difratada em função do ângulo de difração $[2 \theta]$, pode-se obter a largura a meia altura $[\Delta[2 \theta]]$ para o máximo de difração, através do ajuste dos pico de intensidade máxima, com o auxílio do software OriginPro 8 SRO versão 8.0724 [B724]. Os valores de $[\Delta[2 \theta]]$ foram obtidos a partir da função de pico lorentziana. Aplicando-se estes dados à equação de Scherrer [POUGET et al., 1991) se obtém a dimensão média dos domínios cristalinos:

$$
L=\frac{0,9 \lambda}{\Delta(2 \theta) \times \cos \theta}
$$

sendo $\lambda=1,5406 \AA$, o comprimento de onda do raio X utilizado.

2.2.2.1.4 Avaliação morfológica por microscopia eletrônica de varredura. microscópio eletrônico de varredura, MEV [Scanning Electron Microscope, SEM] é um equipamento versátil que permite a obtenção de informações estruturais e químicas de amostras diversas. As amostras obtidas possuem alta profundidade de foco, o que possibilita obter diferentes relevos da superfície da amostra.

A coluna do microscópio eletrônico, que opera em alto vácuo, consiste de uma fonte de elétrons, lentes eletromagnéticas e bobinas de varredura. A fonte de elétrons é normalmente um filamento de tungstênio, que produz elétrons que são acelerados a uma energia na faixa de 1 a $40 \mathrm{KeV}$. Ao incidir na superfície da amostra, ocorre uma interação e parte do feixe é refletida e coletada por um detector, que converte este sinal em imagem.

A microscopia eletrônica de varredura e muito útil para se estudar a morfologia dos materiais. No caso da celulose, procura-se observar características como forma da fibra, diâmetro médio, estrutura e outros. É importante destacar que a celulose não é um 
material condutor de elétrons, sendo necessária, portanto, a aplicação de uma fina camada de material condutor sobre a amostra - no caso, ouro.

Esta técnica permite avaliar a morfologia da superfície das celuloses de partida e residuais [não reagidas durante o processo de hidrólise). Para esta análise foi utilizado o equipamento LEO-440, com filamento de tungstênio para gerar elétrons. As amostras foram secas em estufa de circulação por 4h, colocadas em suporte e recobertas com uma fina camada de ouro.

\subsection{Avaliação do tamanho médio das fibras. Comprimento e espessura} médios das fibras de partida e residuais [não reagidas durante o processo de hidrólise] foram avaliados com o uso de um equipamento MorFi Compact [Techpap], que detecta fibras de tamanhos na escala de micrômetros. Para partículas menores foi utilizada a técnica do espalhamento de luz, com o auxilio de um analisador FOQELS - Fiber-Optic Quasi-Electric Light Scattering [Brookhaven].

\section{Analisador de fibras por imagem [MorFi Compact]}

Trata-se de um equipamento que fornece uma análise de alta resolução para medida de fibras em geral, com destaque para as lignocelulósicas [Figura 22).

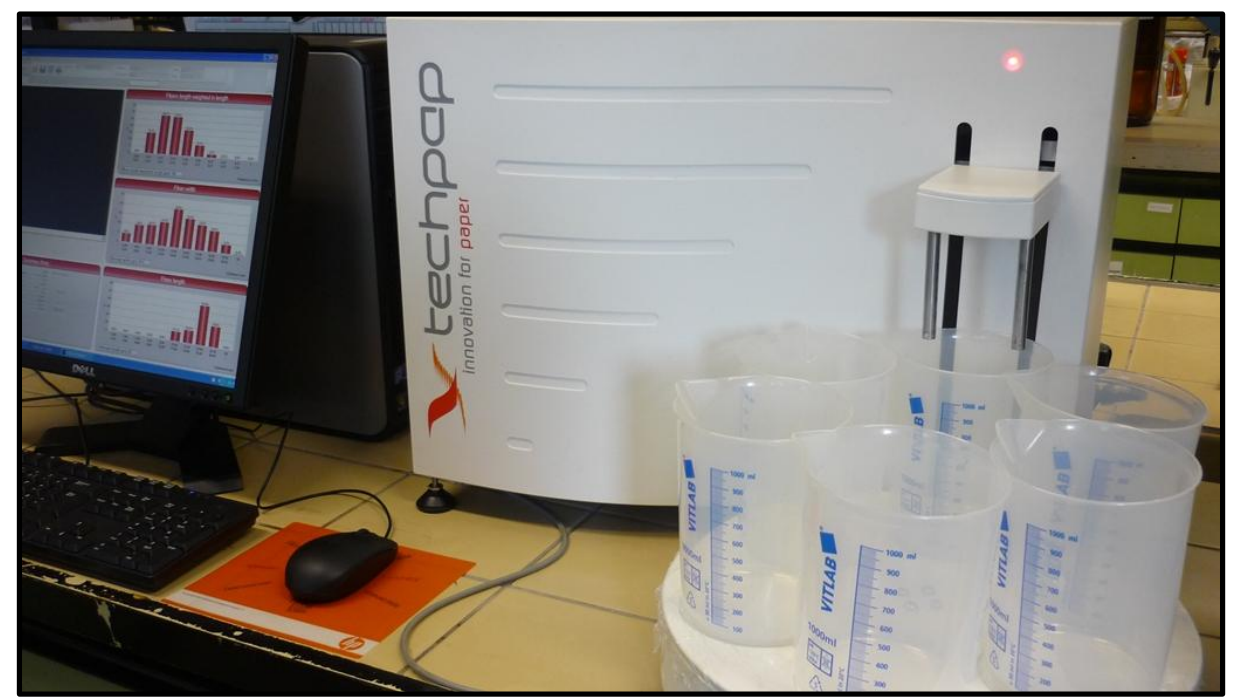

Figura 22 - Analisador de fibras (MorFi Compact - Techpap). 
Este analisador mede as características principais, como comprimento e espessura, de milhares de fibras rapidamente, com alta precisão e sem a necessidade de qualquer tipo de preparo das amostras, já que as medidas são feitas a partir das fibras suspensas em água. A análise acontece em ambiente restrito apenas a fibras, o que permite uma medição estatística confiável de milhares de fibras em alta velocidade, e determinação precisa das características relevantes de sua forma.

\section{Espalhamento de luz [FOQELS]}

Quando uma radiação eletromagnética incide sobre um sistema qualquer, o campo elétrico da radiação induz uma polarização nos elétrons das moléculas que oscila no tempo com a mesma frequência da radiação. As moléculas, por sua vez, passam a ser fontes secundárias de radiação e, por consequência, irradiam a radiação incidente. Essa radiação é a chamada radiação espalhada. As mudanças de frequência, a distribuição angular, a polarização e a intensidade da radiação espalhada dependem do tamanho, forma e das interações moleculares dentro do material irradiado. Logo, a partir das características da radiação espalhada de um dado sistema, é possível obter informações sobre a estrutura e a dinâmica molecular do meio espalhador. As radiações mais comumente utilizadas em experimentos de espalhamento são: luz visivel [laser]; raios X e até mesmo um feixe de nêutrons. A escolha do tipo de radiação baseia-se na escala de comprimentos de interesse e na interação da radiação com a matéria.

Quando moléculas em um volume iluminado são sujeitas a um campo elétrico oscilante proveniente do feixe de luz, suas cargas experimentam uma força e são aceleradas. A consequência é que cada uma dessas moléculas funciona como uma fonte de luz de mesmo comprimento de onda. A intensidade total espalhada em certo ângulo em relação ao feixe incidente [chamado ângulo de espalhamento] é o resultado da soma [superposição] do campo elétrico irradiado por todas as cargas do volume iluminado e, 
consequentemente, seu valor depende da posição exata das cargas. Este é o princípio da técnica de espalhamento estático de luz.

\subsubsection{Mercerização}

A necessidade do pré-tratamento da mercerização para melhora na eficiência da reação de hidrólise ácida de celulose foi avaliada em estudos prévios (LACERDA et al., 2012; DE PAULA et al., 2012]. Além disso, a realização de pré-tratamentos na biomassa que visam diminuir a cristalinade da celulose, como é o caso da mercerização, é de grande importância também para as reações de hidrólise sob catálise enzimática [ROCHA et al., 2012; YANG e WYMAN, 2008; MOSIER et al., 2005].

Para este processo, $20 \mathrm{~g}$ de polpa celulósica foram mantidos em suspensão sob agitação mecânica, em $1 \mathrm{~L}$ de solução 20\% de hidróxido de sódio por 3h a $50^{\circ} \mathrm{C}$, condições que foram determinadas em estudo prévio (LACERDA et al., 2012; DE PAULA et al., 2012]. O material celulósico foi filtrado e lavado até que se obtivesse pH igual ao da água usada para lavagem, sendo então seco estufa de circulação a $105^{\circ} \mathrm{C}$ durante $4 \mathrm{~h}$. As condições usadas foram escolhidas a partir de resultados de estudo prévio [DE PAULA, 2009; LACERDA et al., 2012].

\subsubsection{Hidrólise Ácida}

Nesta etapa, utilizou-se um reator de aço inoxidável da marca Marconi [Figura 23) especialmente fabricado para este fim, com revestimento interno anticorrosivo, com algumas partes totalmente feitas de politetrafluoretileno [teflon]. 0 reator, com três litros de capacidade, é encamisado e está acoplado a um banho termostatizado para que a temperatura no seu interior se mantenha constante durante todo o experimento. 


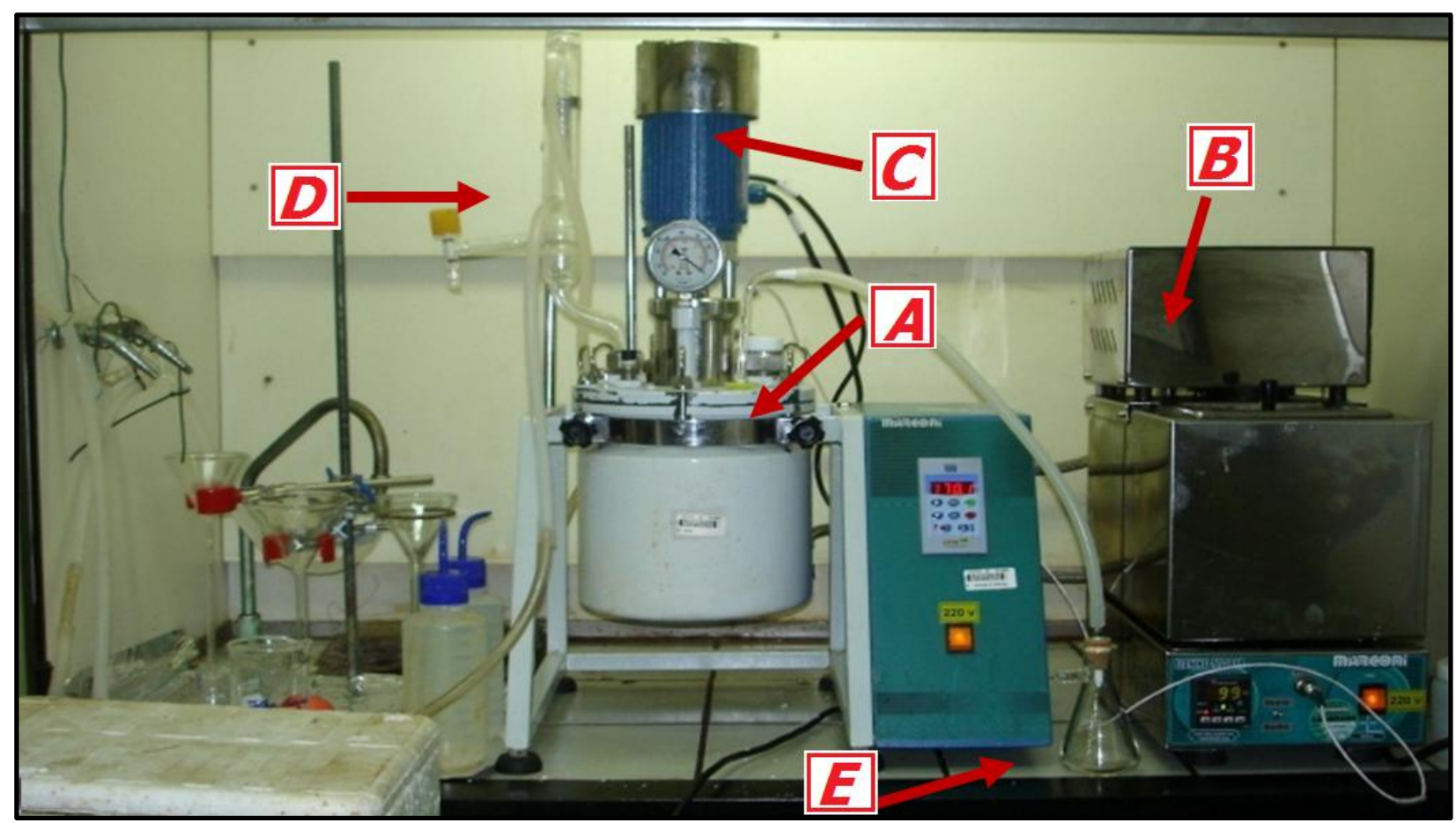

Figura 23 - Reator encamisado "A"; banho termostatizado "B"; rotor de agitação mecânica "C"; condensador "D"; sistema para retirada de alíquotas "E".

Inicialmente, 900 mL de solução ácida previamente preparada na concentração desejada, foram aquecidos a $100^{\circ} \mathrm{C}$, quando $30 \mathrm{~g}$ de celulose em base seca foram adicionados. As concentrações serão expressas em molL-1 para as soluções de ácido sulfúrico e oxálico. Na primeira meia hora de reação, foram retiradas três alíquotas [10, 20 e 30 min], imediatamente filtradas para que o licor contendo o material hidrolisado fosse separado da celulose não hidrolisada, e ambos pudessem ser analisados em uma etapa posterior. Na sequência, as alíquotas foram retiradas em intervalos de tempo de 30 em 30 min, até o total de 6h de reação, resultando em um total de 14 alíquotas ao final de cada reação. O licor, diluído cinco vezes, foi transferido para um frasco âmbar e imediatamente levado para refrigeração, para posterior análise do teor de açúcares e produtos da decomposição por CLAE. Esta análise foi realizada através da detecção dos seguintes compostos no licor: glicose, xilose, arabinose, ácido fórmico, ácido acético, furfural e HMF, em um cromatógrafo líquido de alta eficiência [CLAE] modelo SHIMADZU equipado com detector de índice de refração [RID-6A SHIMADZU] e coluna Aminex HPX 
87H [300 x 7,8 mm BIO-RAD]. A mistura eluente foi composta de ácido sulfúrico 0,005 $\mathrm{molL}^{-1}$ em um fluxo de 0,6 mLmin'. A temperatura do forno [CTO-10A SHIMADZU] foi mantida de $45^{\circ} \mathrm{C}$ e a pressão da bomba [LC-10AD SHIMADZU] variou entre 60 e 80 $\mathrm{kgfcm}^{2}$. As amostras foram previamente filtradas em filtros SEP PAK $\mathrm{C}_{1 в}$ da marca Waters com a finalidade de reter partículas e outros produtos de degradação das amostras. Esses filtros foram ativados com etanol PA e lavados duas vezes com água milli-Q [PASQUINI et al., 2005; MARABEZI, 2009].

A análise dos compostos furfural e HMF foi realizada em um cromatógrafo líquido de alta eficiência [CLAE] modelo SHIMADZU equipado com detector UV-Vis [SPD-10AV SHIMADZU] com comprimento de onda fixo em $274 \mathrm{~nm}$ e coluna $\mu$ Bondapak $^{\text {TM }} \mathrm{C}_{18}$ [Waters]. A mistura eluente foi uma solução de acetonitrila/água milli-Q na proporção de $1: 8[\mathrm{~V} / \mathrm{v}]$, contendo $1 \%[\mathrm{~V} / \mathrm{v}]$ de ácido acético glacial com fluxo de $0,8 \mathrm{mLmin}{ }^{-1}$. A temperatura de análise foi ambiente e a pressão da bomba [LC-10AD SHIMADZU] variou entre 80 e $100 \mathrm{kgfcm}^{2}$. As amostras foram previamente filtradas em filtros MILLEX 0,45 $\mu \mathrm{m}$ da marca Millipore com a finalidade de reter material em suspensão [PASQUINI et al., 2005; MARABEZI, 2009].

Foi utilizado o processador de dados Cromatopac [CR-7A] e o software para tratamento dos dados CLASS-LC10 ambos da SHIMADZU.

Os componentes do hidrolisado (glicose, xilose, arabinose, ácido fórmico, ácido acético, furfural e HMF] foram identificados por comparação através da injeção dos respectivos padrões de grau de pureza cromatográfico e quantificados através das áreas de seus picos. As áreas dos picos de cada padrão e suas respectivas concentrações foram usadas para gerar gráficos de área do pico versus concentração. Através de regressões lineares foram obtidas equações que possibilitaram converter a área do pico de cada componente em concentração [GURGEL, 2010]. 
As celuloses residuais foram lavadas exaustivamente até $\mathrm{pH}$ igual ao da água de lavagem, separadas em tubos tipo "eppendorf" e secas em estufa de circulação a $105^{\circ} \mathrm{C}$ por 4h, para serem caracterizadas da mesma maneira da polpa celulósica de partida.

\subsubsection{1 Ácido sulfúrico $\left[\mathrm{H}_{2} \mathrm{SO}_{4}\right]$ como catalisador}

Os estudos de hidrólise ácida da polpa celulósica de sisal empregando ácido sulfúrico como catalisador foram realizados em função do tempo e da concentração de ácido. A temperatura foi mantida em $100^{\circ} \mathrm{C}$ enquanto foram usadas as concentrações de 0,9, 1,8, 2,8, 3,7 e 4,6 molL-1. A razão sólido-líquido foi de 1:30 [ $\mathrm{gmL}^{-1}$ ], mais especificamente, $30 \mathrm{~g}$ de polpa celulósica em base seca foram carregadas juntamente com $900 \mathrm{~mL}$ de ácido sulfúrico. Estas reações foram realizadas com polpa de celulose não tratada e mercerizada.

Por se tratar de uma reação em fase heterogênea, em uma segunda etapa, foi realizado um estudo da influência do tamanho de partículas e da cristalinidade da polpa celulósica, nas reações de hidrólise ácida, usado ácido sulfúrico como catalisador. Para isso, a polpa de celulose de sisal previamente triturada e mercerizada foi fracionada em um conjunto de peneiras Retsch AS 200 [Embrapa Pecuária Sudeste, São Carlos], com poros de $106 \mu m, 75 \mu m, 45 \mu m$ e $25 \mu m$. As reações foram então executadas com as diferentes frações, a $100^{\circ} \mathrm{C}$ e $4,6 \mathrm{molL}^{-1}$ de ácido sulfúrico. Os resultados desta série de reações foram comparados com aqueles obtidos para a polpa não fracionada.

Finalmente, uma série de reações com variação de temperatura foi realizada com a finalidade de obter o valor da energia de ativação $\left[E_{a}\right]$ da hidrólise de polpa de sisal, sob estas condições. Dessa forma, a concentração de ácido sulfúrico foi mantida em 4,6 molL- ${ }^{1}$, a temperaturas de 60, 70, 80, 90 e $100^{\circ} \mathrm{C}$. 


\subsubsection{2 Ácido oxálico $[\mathrm{COOH}]_{2}$ como catalisador}

A baixa solubilidade do $[\mathrm{COOH}]_{2}$ a temperatura ambiente dificulta a retirada de alíquotas durante o processo, o que não ocorre quando $\mathrm{H}_{2} \mathrm{SO}_{4}$ é usado. Desta forma, uma primeira reação exploratória de hidrólise foi realizada com $[\mathrm{COOH}]_{2} 0,9 \mathrm{molL}^{-1}$, para polpa de celulose sem o tratamento prévio da mercerização. Nesta concentração, o ácido oxálico ainda é solúvel a temperatura ambiente, o sistema de retirada de alíquotas é facilitado, e as alíquotas foram retiradas para tempos similares àqueles descritos para as reações com ácido sulfúrico. Na sequência, reações com $[\mathrm{COOH}]_{2}$ 4,6 $\mathrm{molL}^{-1}$ foram feitas $\left[100^{\circ} \mathrm{C}, \mathrm{t}=1,2,3,4,5,6,8,10,12,14\right.$ e 16h], com polpa de celulose previamente mercerizada.

Em uma segunda etapa, uma série de reações com variação de temperatura foi realizada com a finalidade de obter o valor da $E_{a}$ da hidrólise de polpa de sisal, sob estas condições. Neste caso, a concentração de ácido oxálico foi mantida em 4,6 molL-1 e, devido à baixa solubilidade do ácido oxálico, as temperaturas empregadas foram de 80 , $85,90,95$ e $100^{\circ} \mathrm{C}$.

É importante destacar que, apesar de estarem presentes em grandes quantidades nas reações, os ácidos sulfúrico e oxálico podem ser chamados de catalisadores, de acordo com a IUPAC, que define que um catalisador é uma substância que aumenta a taxa de reação sem modificar a correspondente variação da energia livre de Gibbs, caso não fosse adicionada [IUPAC, 2012].

\subsubsection{Hidrólise Enzimática}

Nesta etapa do trabalho, as reações de hidrólise enzimática foram realizadas visando à produção de açúcares fermentescíveis, que corresponde à primeira etapa da produção do bioetanol. Para este fim, foi usado o complexo enzimático Accellerase 1500 
[Genencor], composto majoritariamente de exoglucanases, endoglucanases, hemicelulases e $\beta$-glicosidases.

Estas reações foram conduzidas em frascos de $250 \mathrm{~mL}$ [Shott], em tampão citrato 0,01 $\mathrm{molL}^{-1}$, concentração que proporciona um $\mathrm{pH}=5$. Para isso, frasco, tampão e polpa celulósica foram previamente esterilizados em autoclave $\left[121^{\circ} \mathrm{C}, 20 \mathrm{~min}\right]$. Após resfriamento, adicionou-se o complexo enzimático ao sistema, que foi mantido em uma câmara incubadora com agitação orbital [Marconi MA410] durante um intervalo de 6h. Três concentrações diferentes do complexo enzimático foram testadas com relação à quantidade de polpa, seguindo informações contidas na ficha técnica fornecida pela empresa concedente, sendo 0,1, 0,3 e 0,5 mL de enzimas por grama de polpa celulósica. O sistema foi mantido a $50^{\circ} \mathrm{C}$, temperatura que corresponde à menor dentro da faixa recomendada pelo fornecedor $\left[50-65^{\circ} \mathrm{C}\right]$, visando condições que minimizam os custos energéticos.

Nos primeiros 30 min de reação, foram retiradas três alíquotas [10, 20 e 30 min], imediatamente filtradas para que o licor contendo o material hidrolisado fosse separado da celulose não hidrolisada, e ambos pudessem ser analisados em uma etapa posterior. Na sequência, as alíquotas foram retiradas em intervalos de tempo de 30 em 30 min, até o total de 6h de reação, resultando em um total de 14 alíquotas ao final de cada reação.

Mercerização e tratamento com ácido oxálico 0,9 molL-1 foram empregados como pré-tratamento na polpa celulósica, sob as condições descritas acima, para fins de comparação frente à reação de hidrólise enzimática, visando à produção de açúcares. 


\subsection{RESULTADOS E DISCUSSÃO}

Em uma etapa inicial deste estudo, realizou-se uma série de reações de hidrólise ácida com o uso de ácido sulfúrico e polpa de celulose de sisal nativa, ou seja, que não passou pelo processo de mercerização. Tendo sido confirmada a importância deste prétratamento, para que melhores rendimentos quanto à produção de açúcares fossem atingidos, todas as etapas subsequentes foram realizadas com celulose mercerizada. Os ácidos sulfúrico e oxálico foram então empregados como catalisadores nas reações de hidrólise ácida de polpa de sisal mercerizada. Tanto os licores contendo o material hidrolisado quanto a polpa residual destas reações foram devidamente caracterizados.

A hidrólise da polpa de sisal também foi avaliada via catálise enzimática, com o uso do complexo enzimático Accellerase 1500 [Genencor]. Nesta etapa do trabalho, a eficiência de dois pré-tratamentos na fibra foi avaliada, sendo mercerização e tratamento com ácido oxálico 0,9 molL ${ }^{-1}$, conforme discutido posteriormente, esta concentração foi escolhida a partir de um conjunto de resultados obtidos usando este ácido como catalisador em reações de hidrólise ácida. Analogamente à reação via catálise ácida, tanto os licores contendo o material hidrolisado quanto a polpa residual destas reações foram caracterizados. 


\subsubsection{CARACTERIZAÇÃO DA POLPA DE PARTIDA}

Os valores obtidos para massa molar média viscosimétrica média [MMis], teor de $\alpha$-celulose e hemiceluloses, e índice de cristalinidade para as amostras de celulose não tratada e mercerizada $\left[50^{\circ} \mathrm{C}, 3 \mathrm{~h}\right]$ são mostrados na Tabela 1.

Tabela 1 - Massa molar média viscosimétrica, teor de celulose e hemiceluloses e índice de cristalinidade das polpas celulósicas.

\begin{tabular}{|c|c|c|c|c|}
\hline Amostra & $\mathrm{MM}_{\text {vis }}\left[\mathrm{gmol}^{-1}\right]$ & $\begin{array}{c}\text { Teor de } \\
\alpha \text {-celulose [\%] }\end{array}$ & $\begin{array}{c}\text { Teor de } \\
\text { hemiceluloses } \\
{[\%]}\end{array}$ & $\begin{array}{c}\text { Índice de } \\
\text { cristalinidade } \\
{[\%]}\end{array}$ \\
\hline $\begin{array}{l}\text { Polpa de sisal } \\
\text { não tratada }\end{array}$ & $115700 \pm 600 *$ & 88 & 12 & 77 \\
\hline $\begin{array}{c}\text { Polpa de sisal } \\
\text { mercerizada } \\
{\left[50^{\circ} \mathrm{C}, 3 \mathrm{~h}\right]}\end{array}$ & $99900 \pm 450$ * & 98 & 2 & 69 \\
\hline
\end{tabular}

*Referem-se ao erro, considerando as três medidas feitas.

Os resultados obtidos mostraram que o processo de mercerização pode ter levado a uma degradação das cadeias celulósicas, ou seja, cisões de ligações glicosídicas das cadeias, levando a uma diminuição das massas molares médias. Além disso, a eliminação de hemiceluloses presentes, devido à mercerização, pode também levar a diminuições da massa molar média. No geral, hemiceluloses possuem menor massa molar média, quando comparadas com a celulose. Entretanto, quando presentes, interagem fortemente com a celulose, o que pode levar a volumes hidrodinâmicos correspondentes à celulose associada a hemiceluloses que se refletem em maior massa molar média, o que não acontece no caso de eliminação parcial ou total das hemiceluloses.

Os resultados para os teores de $\alpha$-celulose mostraram que houve um aumento significativo no teor de celulose pura após a mercerização, decorrente da eliminação de hemiceluloses [Tabela 1]. 
Foram calculados os índices de cristalinidade das polpas celulósicas [difratogramas não mostrados] através da Equação 13, os quais diminuíram para a celulose mercerizada, em relação à polpa de sisal sem tratamento [Tabela 1].

Além disso, foi observado que o processo de mercerização levou à formação de celulose II, devido ao surgimento do pico característico com $2 \theta$ entre $18^{\circ}$ e $22^{\circ}$, ou seja, houve mudança de grande parte da celulose I, presente na amostra sem tratamento, para a celulose II.

A Figura 24 mostra imagens de microscopia eletrônica de varredura para as fibras não tratada e mercerizada.

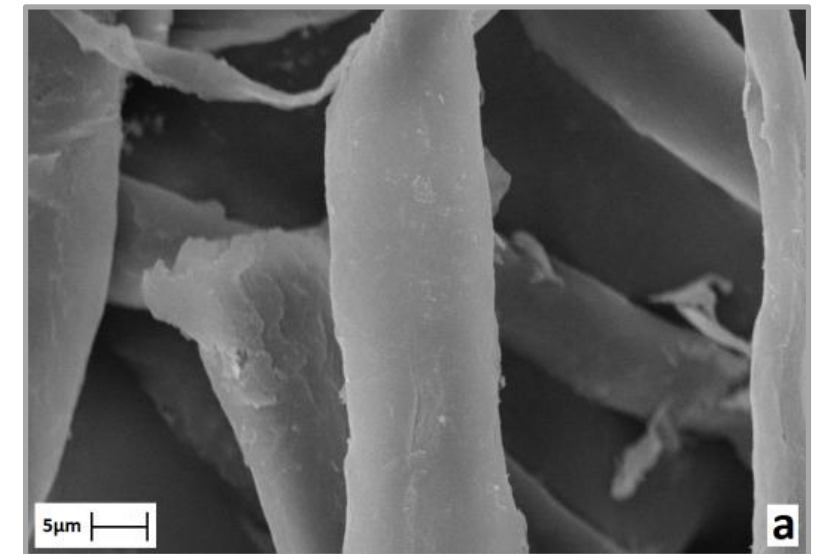

Figura 24 - Micrografias da polpa de celulose de sisal não tratada [a] e mercerizada [b].

Verifica-se que a polpa não tratada [Figura 24-a] possui fibras com as superfícies mais lisas quando comparada com àquela que passou pelo processo de mercerização [Figura 24-b]. Observa-se que este tratamento levou a superfícies mais rugosas, o que pode facilitar posteriormente o processo de hidrólise já que, por se tratar de um processo heterogêneo, o aumento da área superficial leva ao maior contato com a solução ácida.

Na Figura 25 estão ilustrados dois mapas de densidade tridimensionais, que representam a distribuição das fibras de acordo com seus comprimento e espessura, para as polpas de celulose de sisal sem tratamento e mercerizada, em uma análise feita 
em um analisador de fibras (MorFi Compact - Techpap), pela medida de aproximadamente 5000 fibras.
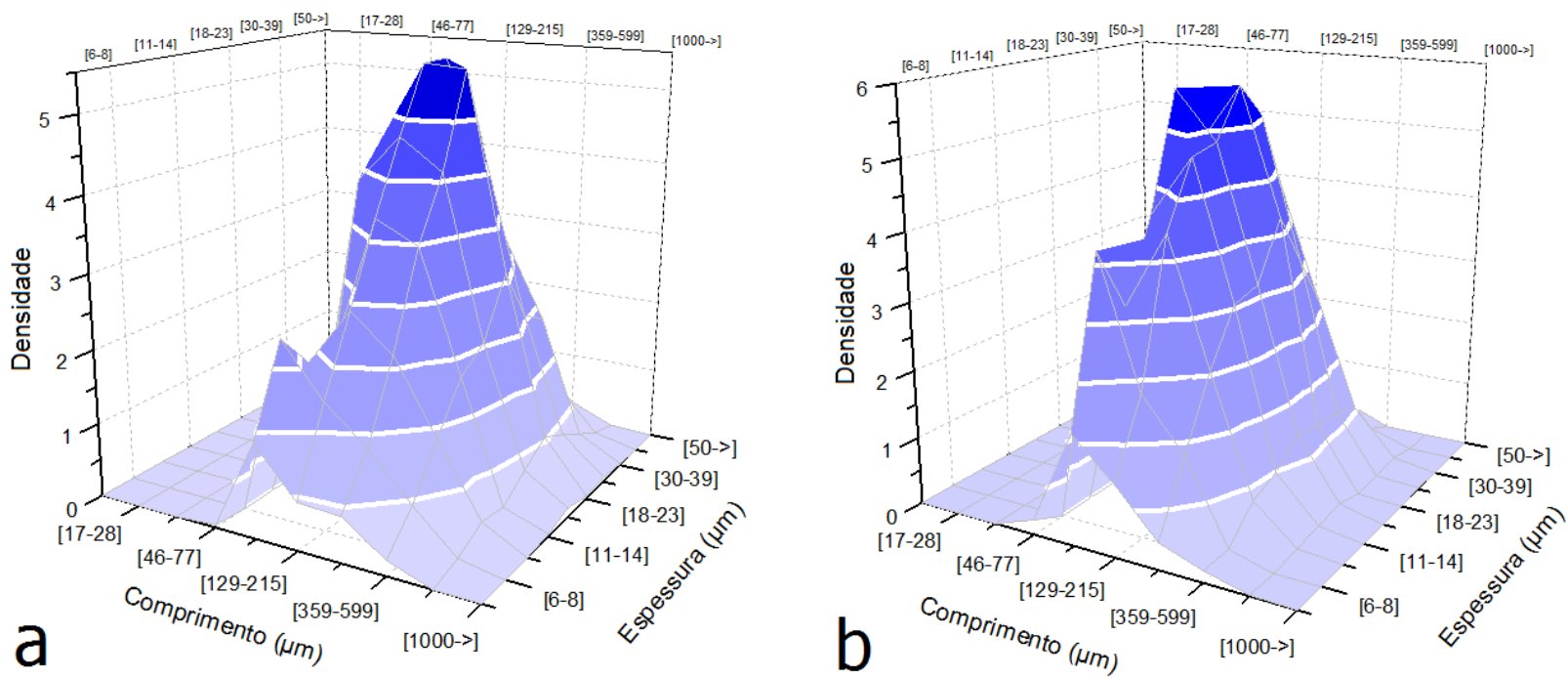

Figura 25 - Mapas de densidade referentes à distribuição de comprimento e espessura das fibras contidas na polpa de sisal não tratada [a] e mercerizada [b]

Observa-se que o tratamento da mercerização desloca a maior densidade das fibras para o sentido de fibras mais curtas [Figura 25], ou seja, a maior densidade de fibras, que estava concentrada na região de comprimentos entre [129-599] um no caso da polpa sem tratamento [Figura 25-a], foi deslocada para a região de comprimentos entre [46-215] um no caso da polpa mercerizada (Figura 25-b). 0 mesmo fenômeno, ainda que em proporções menores, acontece para a espessura, sendo que, em média, as fibras previamente mercerizadas tendem a ser um pouco menos espessas. A maior densidade das fibras se encontra na região de espessuras entre [18-39] um no mapa referente à polpa sem tratamento, e na região de espessuras entre [6-39] um no mapa referente à polpa mercerizada. 


\subsubsection{REAC̣ÕES DE HIDRÓLISE ÁCIDA, COM ÁCIDO SULFÚRICO COMO CATALISADOR}

Em uma primeira etapa, como estudo preliminar, foram realizadas reações de hidrólise ácida de polpa de sisal não tratada, a $100^{\circ} \mathrm{C}$, em cinco diferentes concentrações de ácido: 0,9, 1,8, 2,8, 3,7 e 4,6 molL-1. Estas concentrações foram escolhidas com base em trabalhos anteriores (DE PAULA et al., 2012; LACERDA et al., 2012; DE PAULA, 2009], em que as concentrações de ácido foram expressas em porcentagem [v/v], variando entre 30 e $50 \% \mathrm{H}_{2} \mathrm{SO}_{4}$. As concentrações aqui usadas representam uma continuação destes estudos prévios, com concentrações variando entre 5-25\% $\mathrm{H}_{2} \mathrm{SO}_{4}$ [ $\mathrm{V} / \mathrm{v}$ ], que foram expressas em molL ${ }^{-1}$ neste texto, para fins de comparação entre os dois catalisadores usados [ácidos sulfúrico e oxálico].

Seguindo, o processo de mercerização foi utilizado para avaliar sua influência na eficiência do processo de hidrólise. Para isso, foram feitas reações de hidrólise com a polpa de sisal mercerizada $\left[3 \mathrm{~h}, 50^{\circ} \mathrm{C}\right.$ ], nas mesmas condições em que foram realizadas as hidrólises para a polpa sem tratamento, ou seja, a $100^{\circ} \mathrm{C}$, com concentrações de ácido variando entre 0,9 e 4,6 $\mathrm{molL}^{-1}$. A fim de avaliar a influência do tamanho das partículas e cristalinidade da celulose, foi realizada uma série de reações, a $100^{\circ} \mathrm{C}$ e 4,6 molL $^{-1}$ de ácido sulfúrico, com polpas de diferentes tamanhos médios. Finalmente, a reação usando concentração de 4,6 molL ${ }^{-1}$ de ácido sulfúrico foi escolhida para que, a partir dela, fosse realizada uma série de reações com temperaturas variando entre 60 e $100^{\circ} \mathrm{C}$, com a finalidade de calcular o valor da energia de ativação $\left[E_{a}\right]$ da reação. 


\section{REAC̣ÕES COM POLPA DE SISAL SEM TRATAMENTO}

Como mencionado anteriormente, o estudo das reações de hidrólise ácida partindo de polpa de sisal sem tratamento correspondeu a uma etapa preliminar deste trabalho, e a necessidade de pré-tratamento nas fibras para que melhores rendimentos fossem atingidos foi comprovada em trabalhos anteriores (LACERDA et al., 2012; DE PAULA, 2009). Assim, as caracterizações da polpa residual, ou seja, que não foi totalmente hidrolisada, e do licor contendo o material hidrolisado provenientes das reações envolvendo polpa de sisal mercerizada [descritas posteriormente] receberão maior destaque, comparativamente à descrição feita neste item para polpa sem tratamento [não mercerizada].

A Tabela 2 exprime a representação por códigos das reações de hidrólise nas condições em que foram realizadas.

Tabela 2 - Códigos usados para denominar as reações estudadas $\left(100^{\circ} \mathrm{C}\right]$, de acordo com as condições de concentração do ácido.

\begin{tabular}{|c|c|}
\hline Código & $\begin{array}{c}\text { Concentração de ácido } \\
{\left[\mathrm{molL}^{-1}\right]}\end{array}$ \\
\hline HAS $_{\text {s1100-0,9}}$ & 0,9 \\
\hline HAS $_{\text {sז100 } 1,8}$ & 1,8 \\
\hline HAS $_{\text {sт100:2,8 }}$ & 2,8 \\
\hline $\mathrm{HAS}_{\mathrm{s \tau} 100 \cdot 3,7}$ & 3,7 \\
\hline HAS $_{\text {sт100-4,6 }}$ & 4,6 \\
\hline
\end{tabular}

Sendo que "HAS" é a abreviação de "hidrólise com ácido sulfúrico", ST representa a polpa usada [sem tratamento] seguido da temperatura $\left(100^{\circ} \mathrm{C}\right]$ e da respectiva concentração de ácido [expressa em mol']. Foram analisadas as modificações decorrentes da hidrólise ácida, tanto no licor contendo o material hidrolisado, quanto nas fibras residuais que não foram totalmente hidrolisadas, sendo que estes foram separados por filtração simples. 


\subsubsection{Caracterização da polpa residual}

As polpas residuais de cada reação foram caracterizadas da mesma forma que a polpa de partida.

Na Figura 26 estão mostrados os valores de massa molar média viscosimétrica e índice de cristalinidade das polpas residuais [não hidrolisadas] retiradas durante o curso das reações de hidrólise.
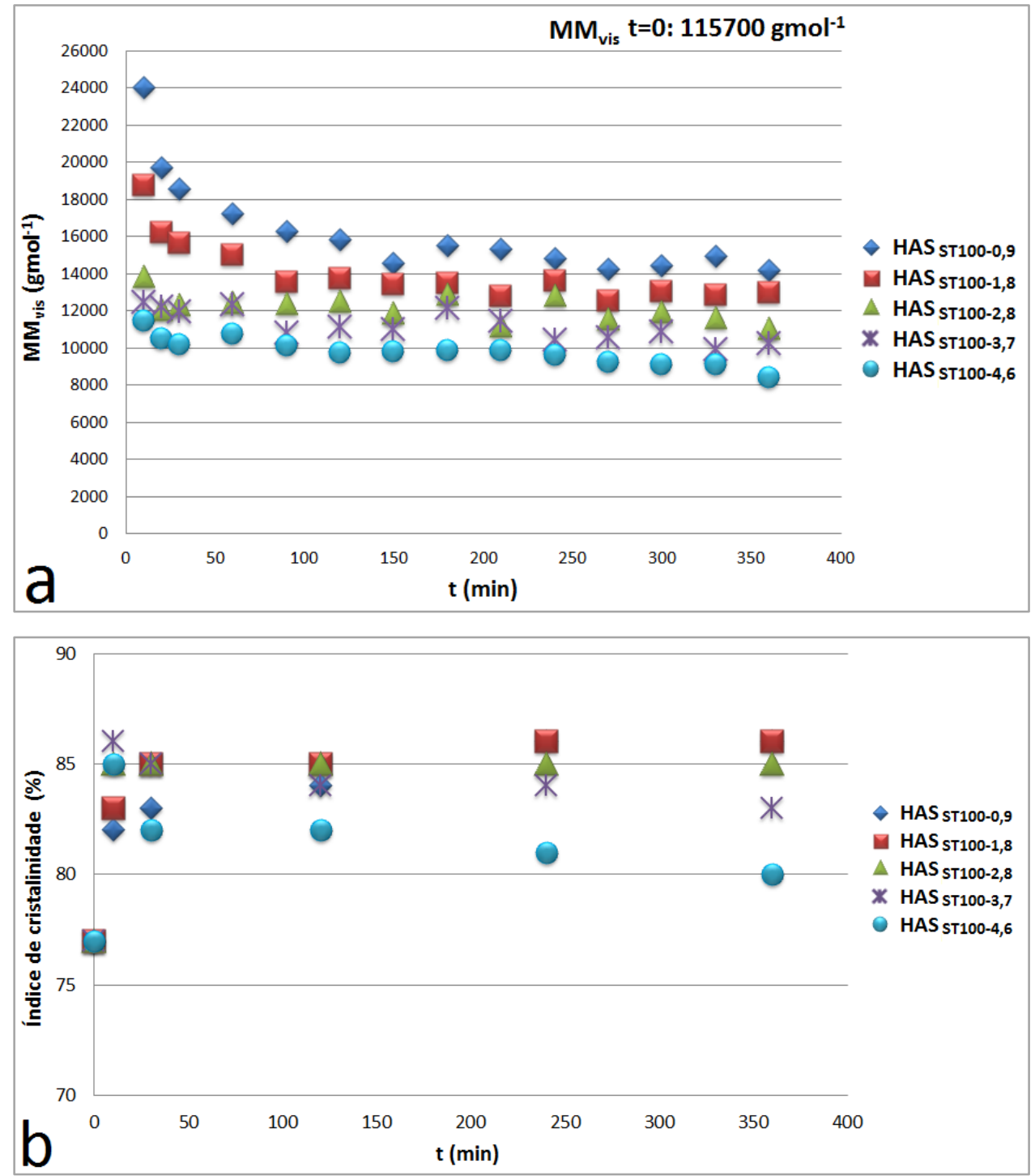

Figura 26 - Valores de [a] massa molar média viscosimétrica e [b] índice de cristalinidade, obtidos a partir da análise das polpas residuais das reações de hidrólise partindo de polpa sem tratamento. 
Os resultados mostram que logo após 10 min de reação, para todas as concentrações de ácido testadas, a celulose tem uma diminuição do valor médio de sua massa molar da ordem de pelo menos cinco vezes [Figura 26-a]. Ainda, para todas as condições de temperatura estudadas, há uma tendência de o valor médio de massa molar permanecer constante após essa queda inicial, sendo que a concentração de 4,6 molL ${ }^{-1}$ corresponde à que levou a maior variação, com $\mathrm{MM}_{\text {wis }}$ mínimo de aproximadamente $8000 \mathrm{gmol}^{-1}$.

A análise de difração de raios $X$ [Figura 26-b] forneceu os valores de índice de cristalinidade $\left[I_{c}\right]$ das polpas residuais das reações feitas. Foram obtidos difratogramas [figuras não mostradas] de cinco amostras de celulose retiradas em diferentes tempos para cada reação realizada, a fim de avaliar a influência do processo de hidrólise na cristalinidade da polpa residual. Os valores de I. foram calculados aplicando-se a Equação 13.

Visto que a hidrólise ocorre com mais facilidade nas regiões não cristalinas, à medida que as cadeias destas regiões são degradadas, a proporção de regiões cristalinas na polpa residual aumenta. É possível notar que o aumento da concentração de ácido faz com que a polpa residual alcance mais rapidamente o máximo índice de cristalinidade [da ordem de 86\%, com 4,6 molL ${ }^{-1} \mathrm{H}_{2} \mathrm{SO}_{4}$, Figura 26-b]. Em contrapartida, também se observa que nesta concentração, a partir do máximo de cristalinidade atingido, se tem uma diminuição mais acentuada da porção cristalina. Ainda, em todos os casos a cristalinidade final da polpa residual é maior do que a da polpa de partida.

O gráfico a seguir mostra a variação das dimensões dos domínios cristalinos das celuloses residuais isoladas [dimensão do plano 002], calculadas de acordo com a Equação 14, em função do tempo nas condições de reação utilizadas $\left(\mathrm{H}_{2} \mathrm{SO}_{4}\right.$ 0,9 - 4,6 $\left.\mathrm{molL}^{-1}, 100^{\circ} \mathrm{C}\right]$ 


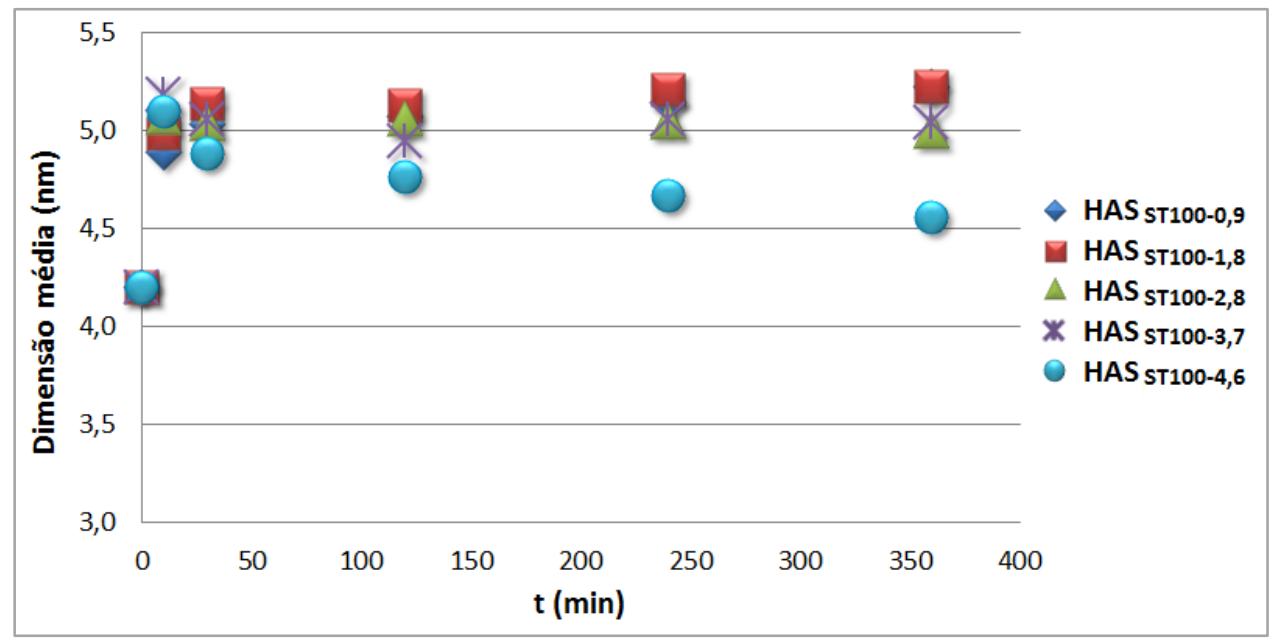

Figura 27 - Dimensão do plano 002 das polpas residuais [não mercerizadas] em função do tempo da reação de hidrólise [concentração de ácido entre 0,9 e 4,6 $\mathrm{molL}^{-1}, 100^{\circ} \mathrm{C}$ ).

A polpa de partida [77\% de cristalinidade] é constituída majoritariamente por regiões cristalinas. Uma mesma cadeia pode ter segmentos fazendo parte de regiões cristalinas e não cristalinas. A hidrólise inicia nas regiões não cristalinas, diminuindo drasticamente a massa molar média das cadeias [Figura 26-a]. Assim, como consequência, segmentos que inicialmente estavam em regiões não cristalinas, podem se rearranjar em empacotamentos mais ordenados, aumentando as dimensões médias dos domínios [Figura 27). Outra possibilidade corresponde à junção de domínios, em consequência da hidrólise das regiões não cristalinas que havia entre eles, o que também aumenta o tamanho médio dos domínios cristalinos. A diminuição subsequente está ligada à próxima etapa, que é a hidrólise das regiões de maior cristalinidade, o que por sua vez leva a uma diminuição dos tamanhos médios dos cristalitos, refletida na dimensão dos planos cristalográficos. Esta diminuição ocorre mais intensamente para a polpa residual da reação com 4,6 molL-1 $\mathrm{H}_{2} \mathrm{SO}_{4}$, sendo de menor intensidade para 3,7 molL ${ }^{-1}$ $\mathrm{H}_{2} \mathrm{SO}_{4}$, e pouco significativa para as outras concentrações. 
Na Figura 28 estão ilustradas as micrografias das polpas residuais obtidas a partir das reações realizadas com polpa sem tratamento e diferentes concentrações de ácido sulfúrico, a $100^{\circ} \mathrm{C}$.
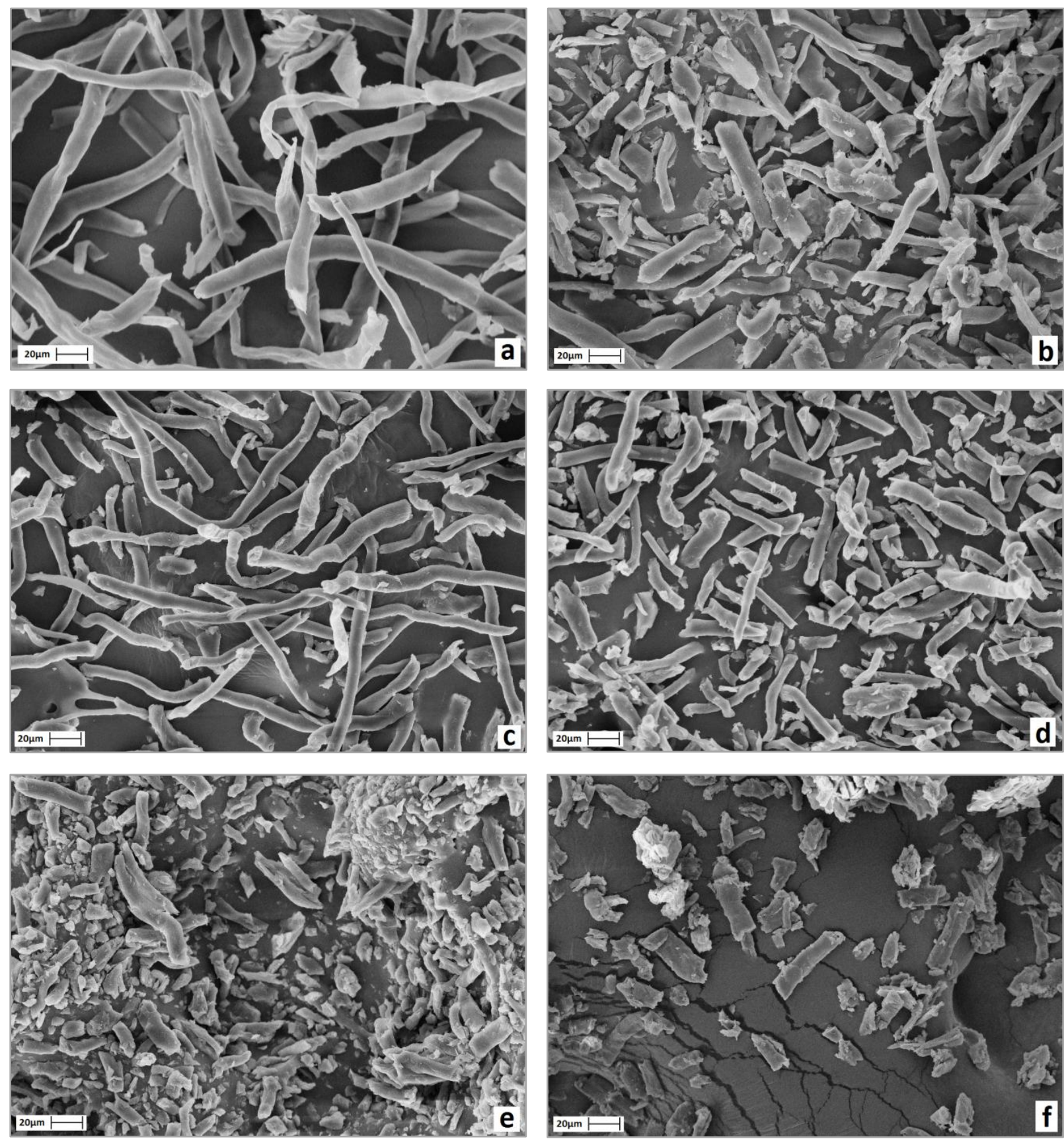

Figura 28 - Micrografias das polpas residuais das reações de hidrólise com polpa sem tratamento, $100^{\circ} \mathrm{C}$, com diferentes concentrações de ácido sulfúrico, sendo: (a) HAS sт1000,9 $_{\text {- 30min; (b) HAS }}$ sт100:0,9 -

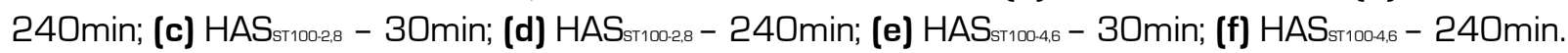


Após 30 min de reação com 0,9 $\mathrm{molL}^{-1}$ de ácido a morfologia fibrosa das fibras se mantém [Figura 28-a] similar às fibras de partida [Figura 24-a], porém com 240 min de reação [Figura 28-b], os feixes de fibras já estão parcialmente fragmentados na superfície. Quando a reação é feita com 2,8 $\mathrm{molL}^{-1} \mathrm{H}_{2} \mathrm{SO}_{4}$, em 30 min de reação [Figura 28-c] já se observa uma maior fragmentação e compactação em relação à Figura 28-a, assim como em d [240 min], se observa feixes de fibras menores e mais finos, indicando que um maior número de camadas reagiu. Para a reação com 4,6 molL ${ }^{-1} \mathrm{H}_{2} \mathrm{SO}_{4}$ e 30 min [Figura 28-e], já é possível observar feixes de fibras mais finos e menores assim como em d [240 min], os feixes de fibras se diferenciam da estrutura fibrosa inicial, assim como em f [4,6 molL-1 $\mathrm{H}_{2} \mathrm{SO}_{4}, 240$ min], quando a fragmentação das fibras é máxima.

\subsubsection{Caracterização dos produtos gerados nas reações de hidrólise}

Conforme descrito na Equação 1, a hidrólise de celulose produz glicose que, em meio ácido pode sofrer decomposição a HMF [Figura 29], que por sua vez é convertido nos ácidos fórmico e levulínico e produtos de condensação.

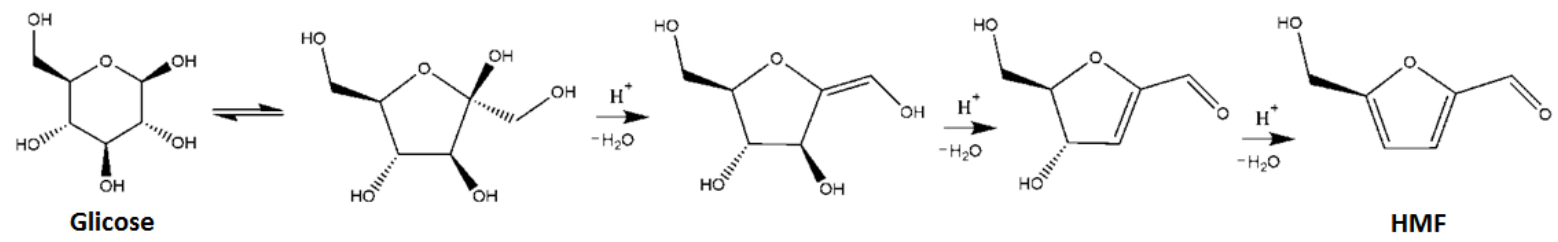

Figura 29 - Reação de desidratação de glicose em meio ácido (adaptado de BELGACEM e GANDINI, 2008].

Analogamente, a hidrólise das hemiceluloses, no caso do sisal constituídas majoritariamente por xilanas [MEGIATTO JÚNIOR et al., 2007], produz furfural [Figura 30]. Além de xilose, outros açúcares de cinco carbonos, como arabinose, também podem se decompor a furfural. 


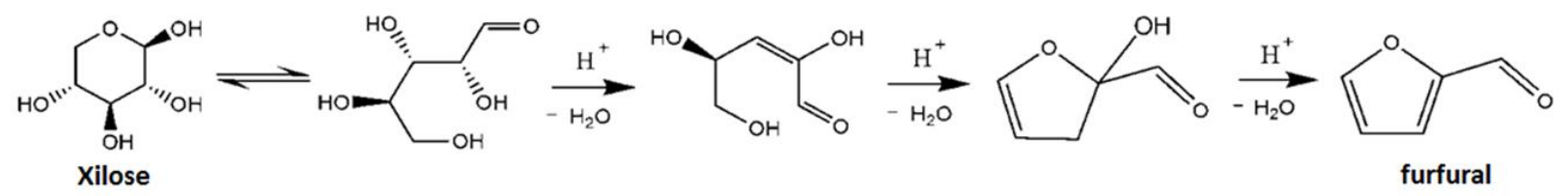

Figura 30 - Reação de desidratação de xilose em meio ácido [adaptado de BELGACEM e GANDINI, 2008).

Além disso, a presença de furfurais em meio ácido, pode levar à formação de produtos de condensação, como polifurfurais [Figura 31-b], e HMF pode se decompor nos ácidos fórmico e levulínico [Figura 31-a].
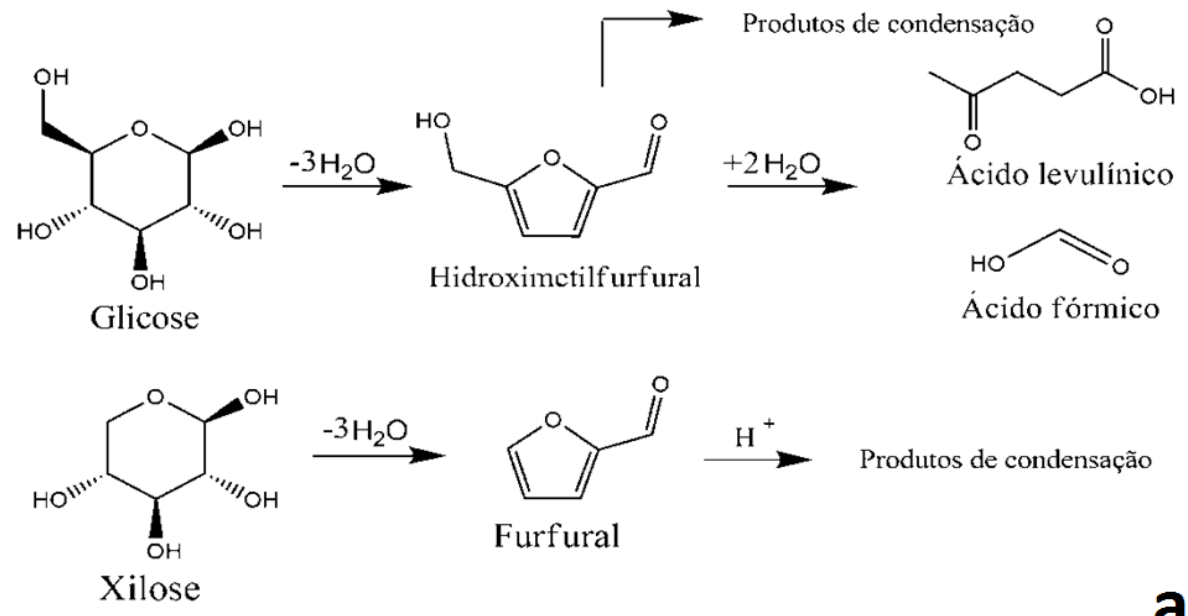

a

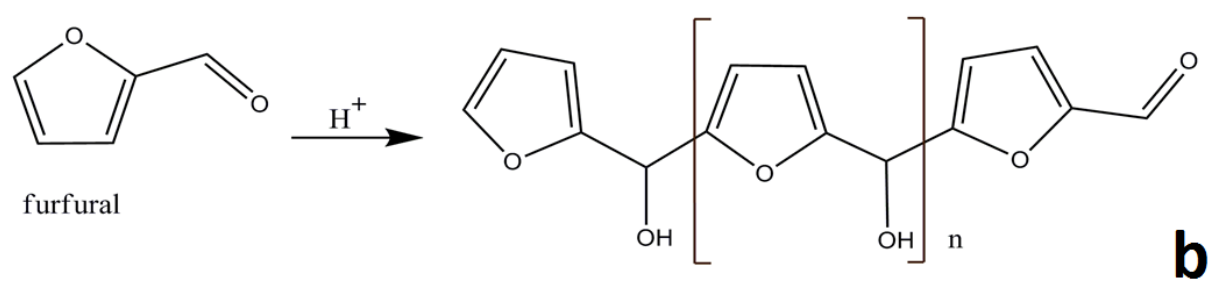

Figura 31 - (a) Reações de decomposição de glicose e xilose [FENGEL e WEGENER, 1984); (b) formação de polifurfural em meio ácido [BELGACEM e GANDINI, 2008).

Os açúcares e derivados que podem ser encontrados nos licores, formados nas reações de hidrólise, estão descritos na Tabela 3. 
Tabela 3 - Natureza dos possíveis açúcares e derivados que podem ser encontrados nos licores obtidos nas reações de hidrólise de polpa celulósica.

\begin{tabular}{|c|c|c|c|c|c|}
\hline $\begin{array}{c}\text { Produtos da } \\
\text { hidrólise de } \\
\text { celulose }\end{array}$ & $H A S_{\$ 1100-0,9}$ & $H A S_{\text {sт1001,8 }}$ & $H A S_{\$ 11002,8}$ & $H A S_{S T 1003,7}$ & $H A S_{\text {sт1004, }}$ \\
\hline Glicose & $x$ & $x$ & $x$ & $x$ & $x$ \\
\hline HMF & $x$ & $x$ & $x$ & $x$ & $x$ \\
\hline Ácido fórmico & $\varnothing$ & $x$ & $x$ & $x$ & $x$ \\
\hline $\begin{array}{c}\text { Produtos da } \\
\text { hidrólise de } \\
\text { hemiceluloses }\end{array}$ & $H A S_{\text {ST100-0.9 }}$ & $H A S_{\text {ธ11001,8 }}$ & $H A S_{\text {ST100:2,8 }}$ & $H A S_{\text {Sт100-3.7 }}$ & $H A S_{s т 1004,6}$ \\
\hline Xilose & $x$ & $x$ & $x$ & $x$ & $x$ \\
\hline Arabinose & $\varnothing$ & $\varnothing$ & $\varnothing$ & $\varnothing$ & $\varnothing$ \\
\hline Ácido acético & $\varnothing$ & $\varnothing$ & $\varnothing$ & $\varnothing$ & $\varnothing$ \\
\hline Furfural & $x$ & $x$ & $x$ & $x$ & $x$ \\
\hline
\end{tabular}

x: detectado; Ø: não detectado

Os resultados mostram que para todas as condições de hidrólise houve formação de glicose, indicando que todas levaram à clivagem das ligações 1,4- $\beta$-glicosídicas das cadeias de celulose, diferindo, no entanto, na extensão em que ocorreram, conforme será descrito posteriormente.

O ácido acético é proveniente da hidrólise dos grupos acetila das hemiceluloses, e possivelmente, se presente, estava em concentração abaixo do limite mínimo de detecção do equipamento utilizado para as análises de CLAE. Ácido fórmico, proveniente da decomposição de HMF [Equação 1), não foi detectado para a reação com 0,9 molL $\mathrm{H}_{2} \mathrm{SO}_{4}$ pelo mesmo motivo.

A arabinose não foi detectada em nenhuma das amostras dos licores provenientes das reações com polpa sem tratamento. Tendo em vista o baixo teor de arabinose nas hemiceluloses no sisal [2,5\%, Figura 10], era esperado que este açúcar não fosse detectado.

As Figuras de $\mathbf{3 2}$ a $\mathbf{3 5}$ são referentes à formação dos produtos provenientes da hidrólise direta da celulose [glicose], e da decomposição da glicose [HMF e ácido fórmico]. 
A Figura 32 mostra as curvas de concentração de glicose em função do tempo de reação para todas as concentrações de ácido sulfúrico consideradas. Deve-se ressaltar que hemiceluloses também podem apresentar glicose em sua composição, entretanto na polpa de sisal, as hemiceluloses são constituídas de aproximadamente २,२\% de glicose [Figura 10] e, como aproximação, a glicose será considerada como proveniente apenas de celulose.

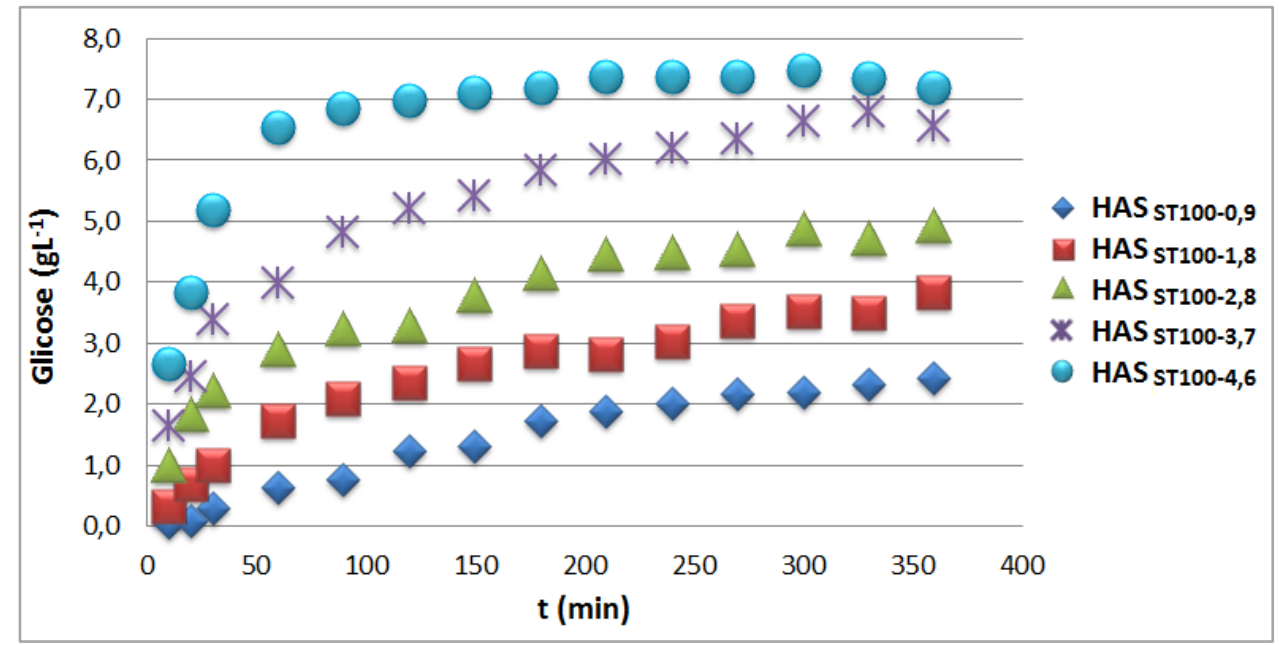

Figura 32 - Concentração de glicose em função do tempo para as reações com diferentes concentrações de ácido $\left(100^{\circ} \mathrm{C}\right)$.

Observa-se que a produção de glicose está diretamente relacionada à concentração de ácido usada, conforme esperado, sendo que o valor máximo obtido foi aproximadamente 7,5 $\mathrm{gL}^{-1}$, após 300 min de reação usando $\mathrm{H}_{2} \mathrm{SO}_{4}$ 4,6 molL-1. Entretanto, após este intervalo de tempo, nota-se uma tendência frente à diminuição do valor da concentração de glicose, justificada pela intensificação da sua decomposição a HMF [Equação 1].

Na Figura 33 estão inseridas curvas de glicose potencial, ou seja, a quantidade de glicose que poderia ser detectada, nas condições consideradas, caso não fosse decomposta. Para isto, além da glicose já presente no licor, a quantidade dos produtos da decomposição da glicose também é considerada, somando-se à concentração de glicose 
as respectivas concentrações de HMF e ácido fórmico [Figura 34 e 35]. É importante destacar que os valores de glicose potencial correspondem a uma aproximação, pois estão sendo levadas em conta apenas as concentrações de HMF e ácido fórmico, ou seja, valores de concentração de ácido levulínico, também produto da decomposição de HMF, ou de outros produtos de decomposição que não foram analisados, não foram considerados para estes cálculos.

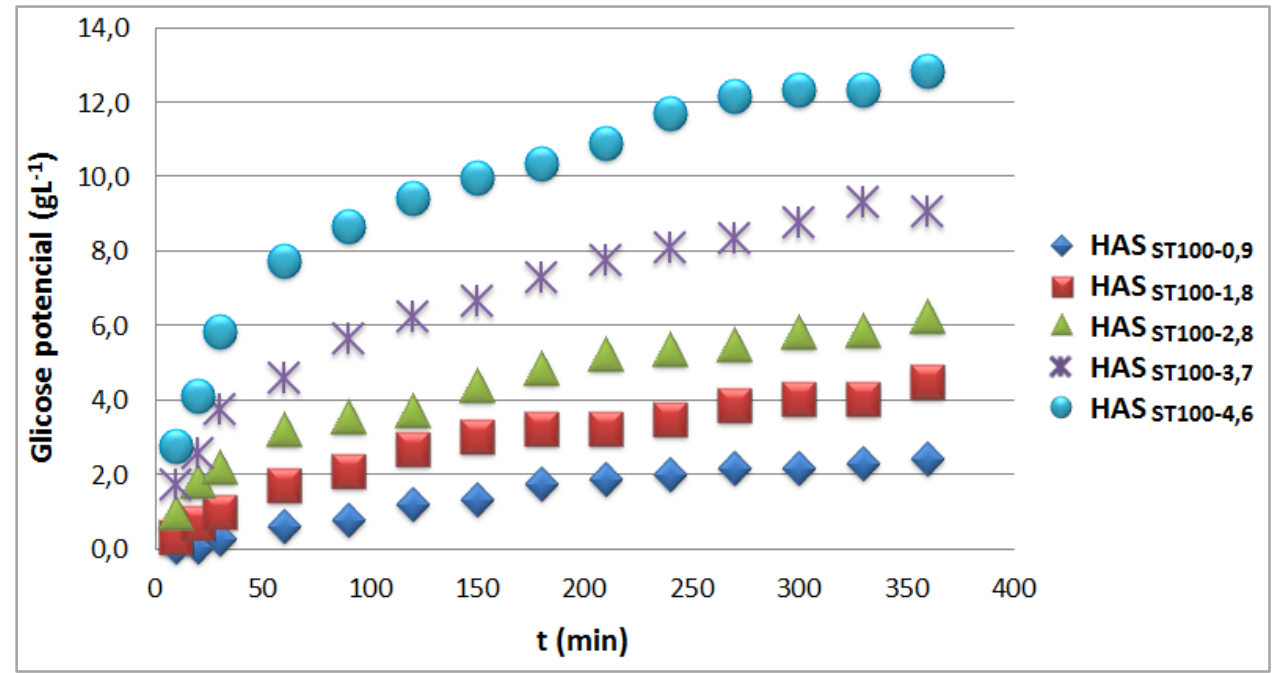

Figura 33 - Concentração de glicose potencial em função do tempo de hidrólise e da concentração de ácido.

Os cálculos para a obtenção dos valores aproximados de glicose potencial estão descritos na seção "Anexos" [Capítulo 5].

A presença de HMF em todas as amostras analisadas [Tabela 3] indica que todas as condições de reação levaram à decomposição parcial de glicose via reação de desidratação. A Figura $\mathbf{3 4}$ mostra as concentrações de HMF detectadas nas reações estudadas. 


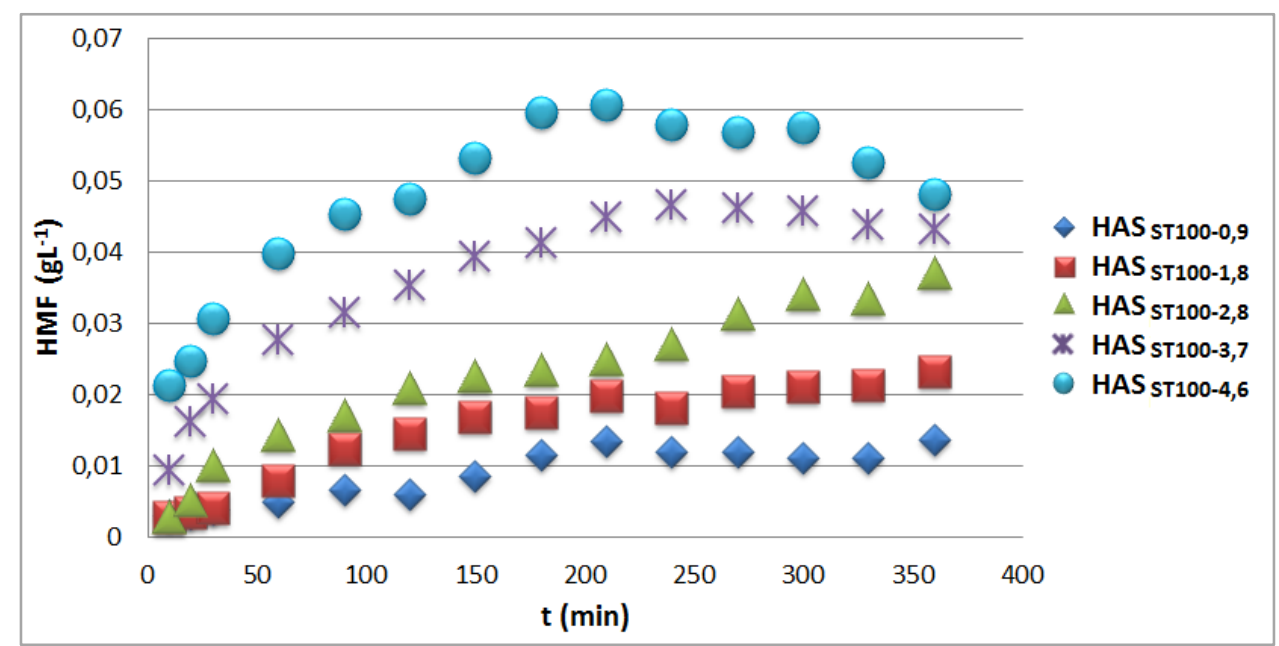

Figura 34 - Concentração de HMF no licor em função do tempo de hidrólise e da concentração de ácido.

0 aumento da concentração do ácido de 0,9 para 4,6 $\mathrm{molL}^{-1}$ favoreceu a desidratação da glicose, acarretando no aumento de quatro vezes da produção de HMF [Figura 34] após 200 min de reação, quando a concentração de aproximadamente 0,015 $\mathrm{gL}^{-1}$ de HMF, obtida quando a menor concentração de ácido foi usada [reação

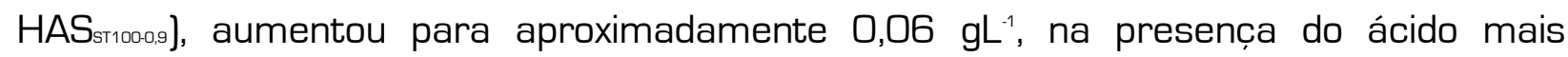
concentrado $\left[\mathrm{HAS}_{\mathrm{s} 1004,6}\right]$.

O ácido fórmico é um produto da decomposição do HMF em presença de ácido, tendo sido encontrado em todas as condições de reação, com exceção da reação HAS $_{\text {sт100-,9. }}$ A Figura 35 mostra as concentrações de ácido fórmico no licor para todas as condições de reação em que foi detectado. 


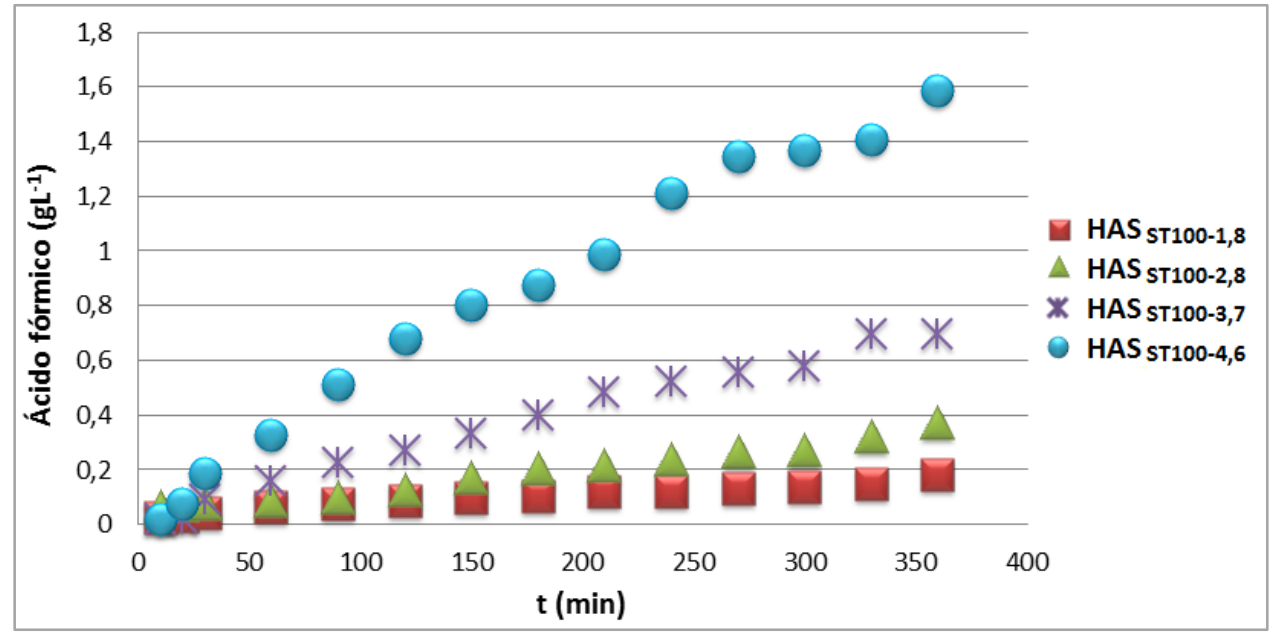

Figura 35 - Concentração de ácido fórmico no licor em função do tempo de hidrólise e da concentração de ácido.

É possível notar que é grande a diferença de concentração de ácido fórmico em relação ao HMF. A estabilidade do HMF nestas condições é extremamente baixa, levando à formação de ácido fórmico e levulínico [não analisado, devido não disponibilidade de padrão para análise via CLAE]. Ainda, nota-se que o ácido fórmico não esteve presente no licor proveniente da reação com ácido sulfúrico menos concentrado [HAS $\mathrm{H}_{\text {sт10-0.9, }}$ ], indicando que possivelmente a estabilidade do HMF seja maior nesta condição, formando quantidades de ácido fórmico que estavam abaixo do limite mínimo de detecção do equipamento.

As Figuras de $\mathbf{3 6}$ a $\mathbf{3 8}$ são referentes à formação dos produtos provenientes da hidrólise das hemiceluloses, ou seja, xilose e furfural. Arabinose não foi detectada nas condições aqui testadas.

A Figura 36 mostra a variação de concentração de xilose no licor, para reações realizadas a $100^{\circ} \mathrm{C}$ e polpa de sisal sem tratamento, com concentração de $\mathrm{H}_{2} \mathrm{SO}_{4}$ variando entre 0,9 e 4,6 $\mathrm{molL}^{-1}$. 

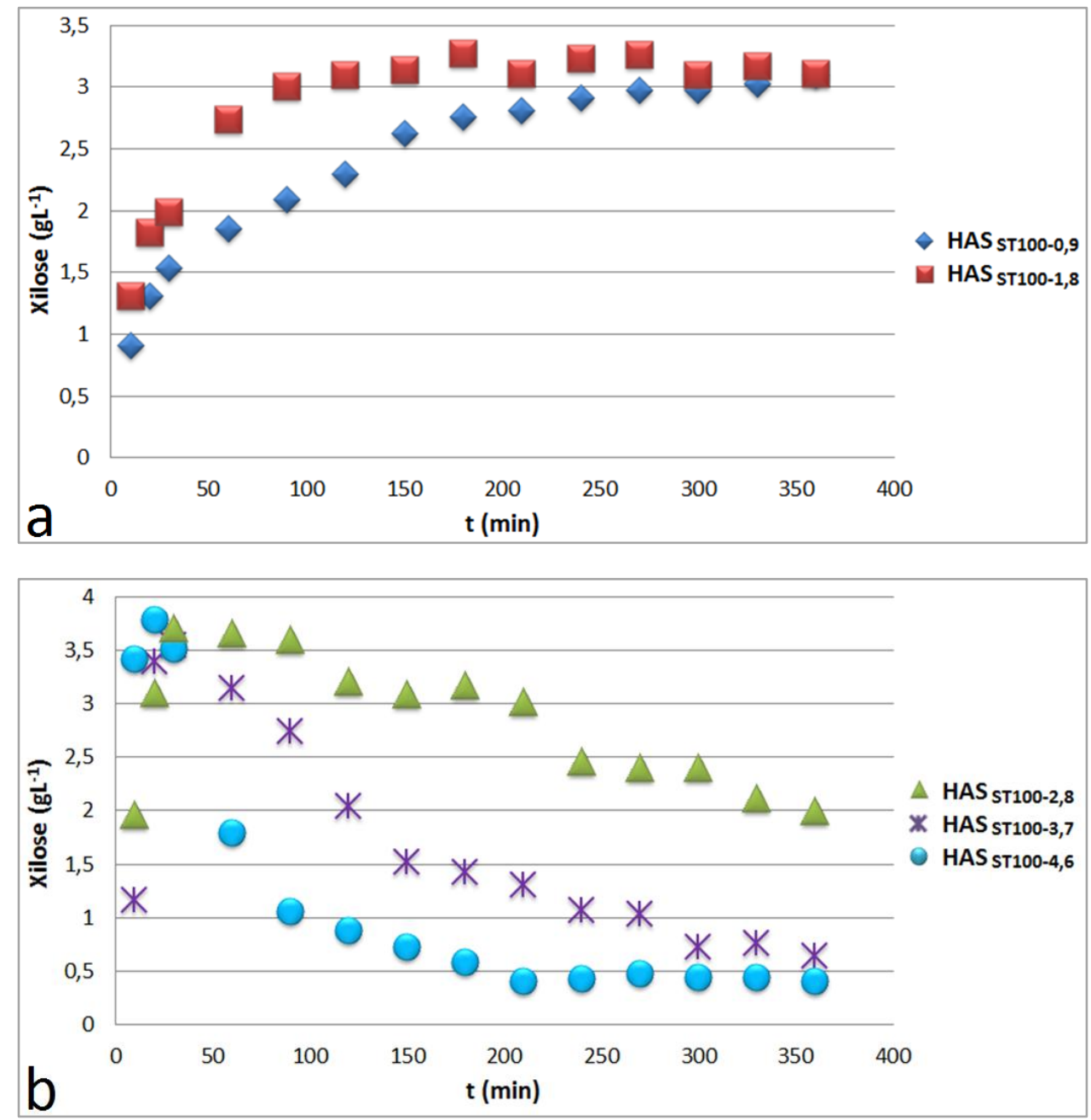

Figura 36 - Concentração de xilose no licor em função do tempo de hidrólise e da concentração de ácido $\left[100^{\circ} \mathrm{C}\right]$

Nota-se que para as concentrações de ácido iguais a 0,9 e 1,8 molL-1, a concentração de xilose presente no meio aumenta até um certo intervalo de tempo, mantendo-se constante em seguida. Para HAS $_{\text {sт100-0,9 }}$ este evento ocorre em t $=270$ min e

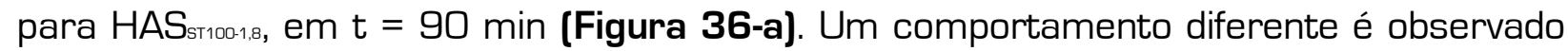

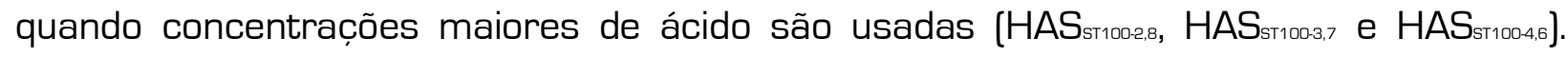
Para estas reações, inicialmente ocorre o aumento da concentração de xilose, sendo que esta atinge um valor máximo, seguido de diminuição. Das três reações estudadas que seguem este comportamento, aquela em que o valor máximo de concentração de xilose é atingido em um menor intervalo de tempo é a reação com 4,6 molL ${ }^{-1}$ de ácido, sendo que aproximadamente 4,0 $\mathrm{gL}^{-1}$ de xilose estão presentes no meio logo nos 20 min iniciais da 
reação. Entretanto este valor diminui pela metade após 1h de reação, o que acontece de forma mais branda quando as concentrações de 2,8 e 3,7 molL ${ }^{-1}$ de ácido são usadas. Estes resultados indicam que a $100^{\circ} \mathrm{C}$ a xilose é relativamente estável a concentrações de $\mathrm{H}_{2} \mathrm{SO}_{4}$ abaixo de 1,8 $\mathrm{molL}^{-1}$, mas altamente instável à medida em que este valor aumenta.

Considerando que a xilose representa $68 \%$ do total de hemiceluloses da fibra de sisal [Figura 10], é possivel estimar se toda hemicelulose contida na polpa foi hidrolisada nas condições consideradas nesta série de reações. Para isso, foi calculado o quanto de xilose haveria no licor, se toda hemicelulose fosse hidrolisada, considerando o total em massa de hemiceluloses presente na polpa sem tratamento, que foi de aproximadamente 12\% [Tabela 1). Estes cálculos estão descritos na seção "Anexos" [Capítulo 5].

0 valor encontrado foi de 3,1 $\mathrm{gL}^{-1}$, e está abaixo dos valores máximos encontrados nos licores por CLAE [aproximadamente 3,8 gL-1]. Estes cálculos são baseados na porcentagem de hemicelulose encontrada na polpa e na porcentagem de xilose encontrada na fibra de sisal, o que embute erros experimentais. Adicionalmente, o valor encontrado é comparado com aquele obtido via CLAE, que também pode conter erros experimentais. Vale salientar que a quantificação do teor de xilose presente nas hemiceluloses foi realizada a partir da fibra de sisal, o que pode ser diferente no caso da polpa kraft usada nas reações aqui descritas.

Contudo, pode-se considerar que em todas as reações estudadas, praticamente toda a hemicelulose foi hidrolisada, já que foram detectados valores maiores de concentração de xilose do que o estimado pelos cálculos. No caso das maiores concentrações de $\mathrm{H}_{2} \mathrm{SO}_{4}$, este valor foi atingido logo nos instantes iniciais da reação [20 min para a reação $\mathrm{HAS}_{\mathrm{s} 1004,6,}$, Figura 36-b], enquanto no caso das reações envolvendo 
menores concentrações de ácido, a concentração máxima de xilose foi atingida nos

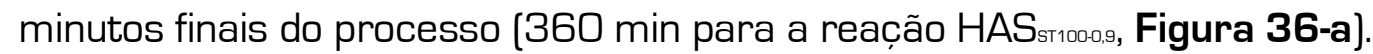

Todas as condições reacionais levaram à decomposição da xilose, o que foi comprovado pela presença de furfural em todos os licores obtidos. As hemiceluloses presentes na polpa celulósica não apresentam regiões cristalinas, além de possuírem baixa massa molar média, o que facilita a penetração dos prótons e das moléculas de água nas regiões em que se encontram as cadeias de hemiceluloses, fazendo com que a xilose seja rapidamente formada como produtos de hidrólise e, consequentemente, rapidamente decomposta. A Figura 37 mostra a formação de furfural em função do tempo de hidrólise.

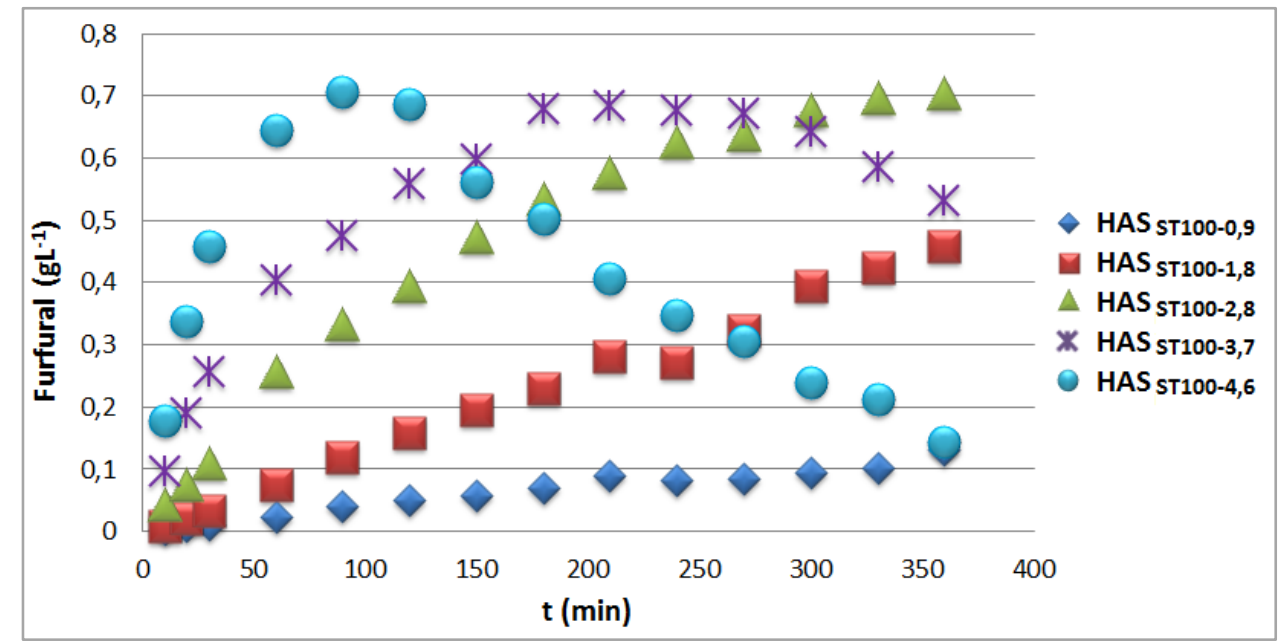

Figura 37 - Concentração de furfural no licor em função do tempo de hidrólise e da concentração de ácido $\left[100^{\circ} \mathrm{C}\right]$.

Observa-se que o aumento da concentração de ácido de 0,9 para 4,6 moll-1 levou a um considerável aumento da produção de furfural no meio reacional. Ainda, observando o perfil das curvas [Figura 37), nota-se que $H A S_{s т 1003,3,}$ e $H A S_{\text {s11004,6, }}$ alcançam um limite máximo de concentração e a partir daí a taxa de formação é menor que a de decomposição, e as concentrações começam a declinar até que, após Gh de reação, $\mathrm{HAS}_{\mathrm{s} 1004,6}$ chega a um valor aproximadamente sete vezes menor que o máximo atingido. 
Isso provavelmente está relacionado ao fato de que a formação de produtos de condensação [Figura 31-b] é favorecida nestas concentrações de $\mathrm{H}_{2} \mathrm{SO}_{4}$. De fato, foram observados precipitados de coloração marrom nos licores resultantes da hidrólise de açúcar, após o resfriamento, indicando que houve formação de polifurfurais, nestas condições. 


\section{REAC̣ÕES COM POLPA DE SISAL MERCERIZADA}

A Tabela 4 exprime a representação por códigos das reações de hidrólise nas condições em que foram realizadas.

Tabela 4 - Códigos usados para denominar as reações estudadas $\left(100^{\circ} \mathrm{C}\right.$ ), de acordo com as condições de concentração do ácido.

\begin{tabular}{cc}
\hline Código & $\begin{array}{c}\text { Concentração de ácido } \\
\text { [molL-1] }\end{array}$ \\
\hline HAS $_{\mathrm{m100-0,9}}$ & 0,9 \\
HAS $_{\mathrm{m100-1,8}}$ & 1,8 \\
HAS $_{\mathrm{m100-2,8}}$ & 2,8 \\
HAS $_{\mathrm{m100-3,7}}$ & 3,7 \\
HAS $_{\mathrm{m1004,6}}$ & 4,6 \\
\hline
\end{tabular}

Sendo que "HAS" é a abreviação de "hidrólise com ácido sulfúrico", M representa a celulose usada [mercerizada] seguido da temperatura $\left(100^{\circ} \mathrm{C}\right.$ ) e da respectiva concentração de ácido [expressa em molin]. Foram analisadas as modificações decorrentes da hidrólise ácida, tanto no licor contendo o material hidrolisado, quanto nas fibras residuais que não foram totalmente hidrolisadas, mesmo procedimento descrito para as reações partindo de polpa sem tratamento.

\subsubsection{Caracterização da polpa residual}

Na Figura 38 estão mostrados os valores de massa molar média viscosimétrica e índice de cristalinidade das polpas residuais após reações de hidrólise. 

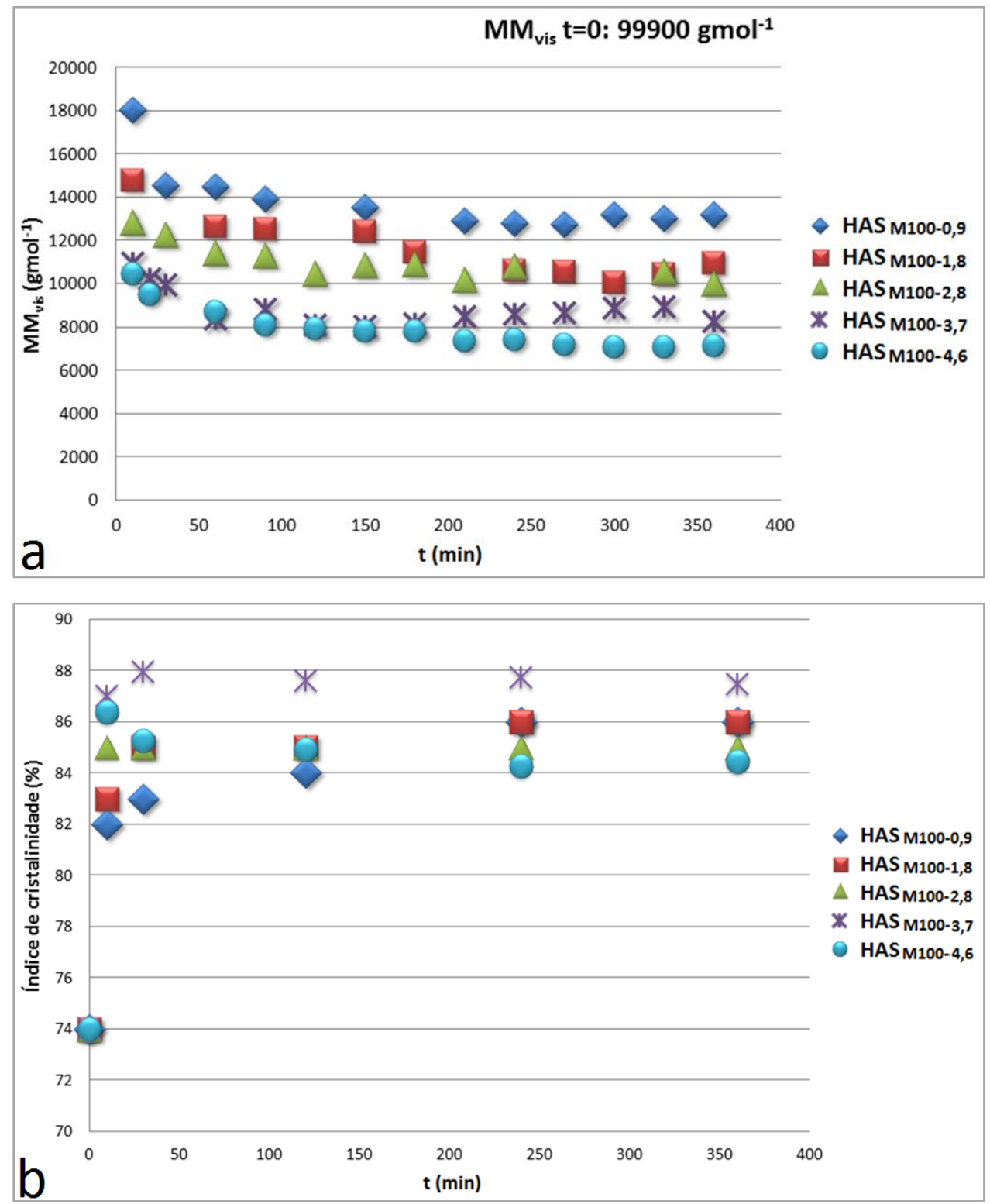

Figura 38 - Valores de [a] massa molar média viscosimétrica e [b] índice de cristalinidade das polpas residuais das reações de hidrólise partindo de polpa mercerizada.

Mesmo depois de um curto período de tempo de reação [10 min], para todas as concentrações de ácido, a celulose apresenta uma diminuição da ordem de pelo menos cinco vezes do seu valor inicial de massa molar média [99900 gmol $^{-1}$, Figura 38-a]. Ainda, há uma tendência de este valor permanecer constante após a queda inicial, sendo que a concentração de 4,6 molL $^{-1}$ corresponde à que levou a uma maior variação, com MMvis mínimo de aproximadamente 7000 gmol $^{-1}$ [Figura 38-a). 
Em todos os casos, houve primeiramente um aumento significativo no valor de $I_{\text {c }}$ [Figura 38-b], pois nas primeiras etapas da hidrólise a fração não cristalina da polpa celulósica, de fácil acesso, foi hidrolisada, enquanto a fração cristalina, de difícil acesso, não reagiu, levando a um aumento na cristalinidade. É possível notar que o aumento da concentração de ácido faz com que a polpa residual alcance mais rapidamente o máximo I. [aproximadamente 87\% para 3,7 $\mathrm{molL}^{-1} \mathrm{H}_{2} \mathrm{SO}_{4}$ ]. Em contrapartida, também se observa que nesta concentração, a partir do máximo de cristalinidade atingido, se tem uma diminuição mais acentuada da cristalinidade. Por exemplo, para 4,6 $\mathrm{molL}^{-1} \mathrm{H}_{2} \mathrm{SO}_{4}$ se tem uma indicação que a partir de aproximadamente 30 min, cadeias dos domínios cristalinos começam a ser hidrolisadas. Ainda, em todos os casos a cristalinidade final da polpa residual é maior do que a polpa de partida. Para concentrações de ácido de 0,9, 1,8, 2,8 e 3,7 molL $^{-1}$ a cristalinidade da polpa residual aumenta cerca de $12 \%$, comparativamente à polpa de partida e depois se mantém aproximadamente constante. Para a concentração de 4,6 molL-1, nota-se a diminuição de $\mathrm{I}_{\mathrm{c}}$, após o aumento inicial, embora se mantenha acima do valor da polpa de partida.

A Figura 39 mostra a relação de domínios cristalinos para as polpas residuais provenientes das reações de hidrólise feitas a partir de celulose mercerizada.

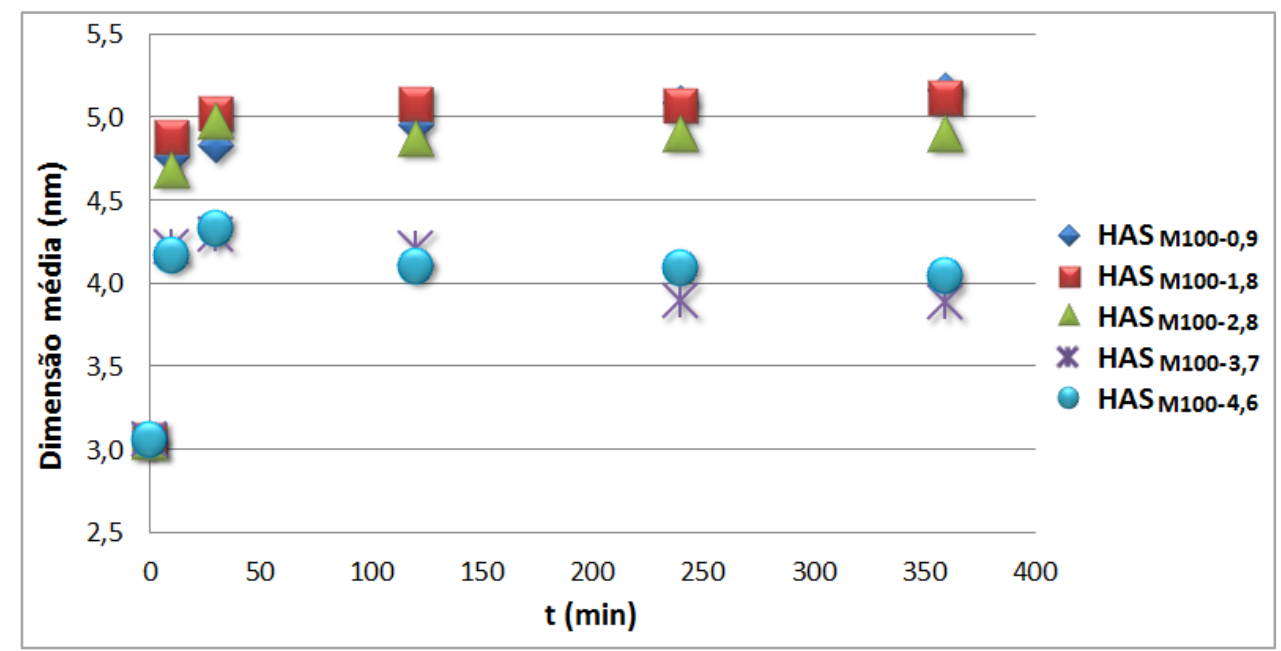

Figura 39 - Dimensão do plano 002 das polpas residuais mercerizadas, em função do tempo de hidrólise $\left[100^{\circ} \mathrm{C}, 0,9\right.$ - 4,6 $\left.\mathrm{molL}^{-1} \mathrm{H}_{2} \mathrm{SO}_{4}\right]$. 
É possível observar que para todos os casos ocorre um aumento expressivo nas dimensões dos domínios cristalinos nos primeiros 30 min de reação, sendo que este comportamento é mais acentuado para as reações que envolveram menores concentrações de ácido [HAS м100-0,9, $_{\text {HAS }}$ м100-1,8 $_{\text {e }} \mathrm{HAS}_{\text {м100-2,8}}$ ], quando estes valores mantiveram-se praticamente constantes durante todo o tempo. Como mencionado anteriormente, nestes casos pode ter ocorrido junções e reorganizações de segmentos mais intensamente. Para as reações com maiores concentrações de ácido $\left[\mathrm{HAS}_{\mathrm{m1003,7}} \mathrm{e}\right.$ $\operatorname{HAS}_{\text {M100-4,6}}$ ], o aumento inicial foi de menor magnitude, e as dimensões dos domínios cristalinos apresentaram diminuição para tempos maiores de reação. Nestes casos, após o aumento, o valor médio das dimensões dos domínios cristalinos caiu gradativamente até um valor de aproximadamente $4,0 \mathrm{~nm}$, o que a princípio está relacionado ao fato de que o tratamento alcalino pode ter separado mais os feixes de fibras, facilitando o acesso dos reagentes, o que se estende até as regiões cristalinas.

A Figura 40 mostra as micrografias das polpas residuais obtidas a partir das reações realizadas com polpa mercerizada como material de partida e diferentes concentrações de ácido sulfúrico, a $100^{\circ} \mathrm{C}$. 

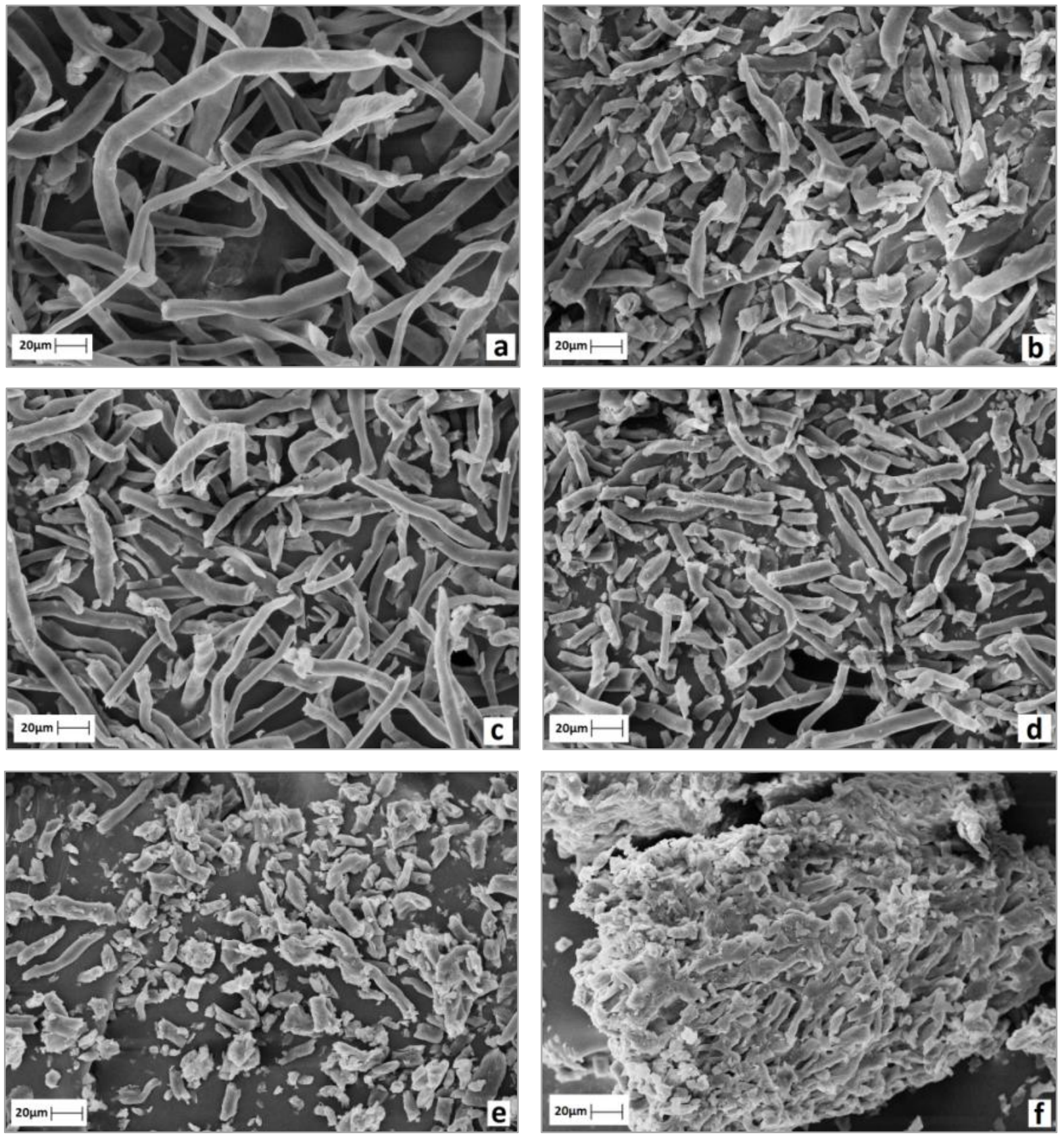

Figura 40 - Micrografias das polpas residuais das reações de hidrólise realizadas a $100^{\circ} \mathrm{C}$, com

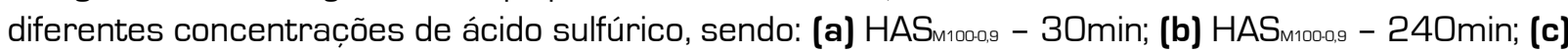
$\mathrm{HAS}_{\text {м1002, }}$ - 30min; (d) HAS

Observa-se pela Figura 40 [a, b, c, d] que nas concentrações de 0,9 e 2,8 $\mathrm{molL}^{-1}$, mesmo após 4h de reação, a morfologia das fibras permaneceu semelhante à de partida [Figura 24]. Porém, a concentração de $\mathrm{H}_{2} \mathrm{SO}_{4}$ igual a 4,6 molL-1 [Figura 40-e,f] permitiu uma maior fragmentação e compactação das fibras em relação às outras amostras, o 
que é indicado pela aglomeração das fibras, fenômeno que também pode ser consequência do processo usado para isolar e secar as fibras. Ainda, é importante salientar que nas amostras e, f se observa feixes de fibras menores e mais finos, indicando que cadeias presentes em um maior número de camadas reagiram, levando a diminuição no espessamento.

Na Figura 41 estão contidos os mapas de densidade referentes às medidas de tamanhos médios de fibras das polpas não hidrolisadas durante as reações, para tempos iguais 3 e 6h. Para estas medidas foi usado o equipamento MorFi Compact [Techpap], ou seja, são medidas envolvendo material em escala micrométrica.
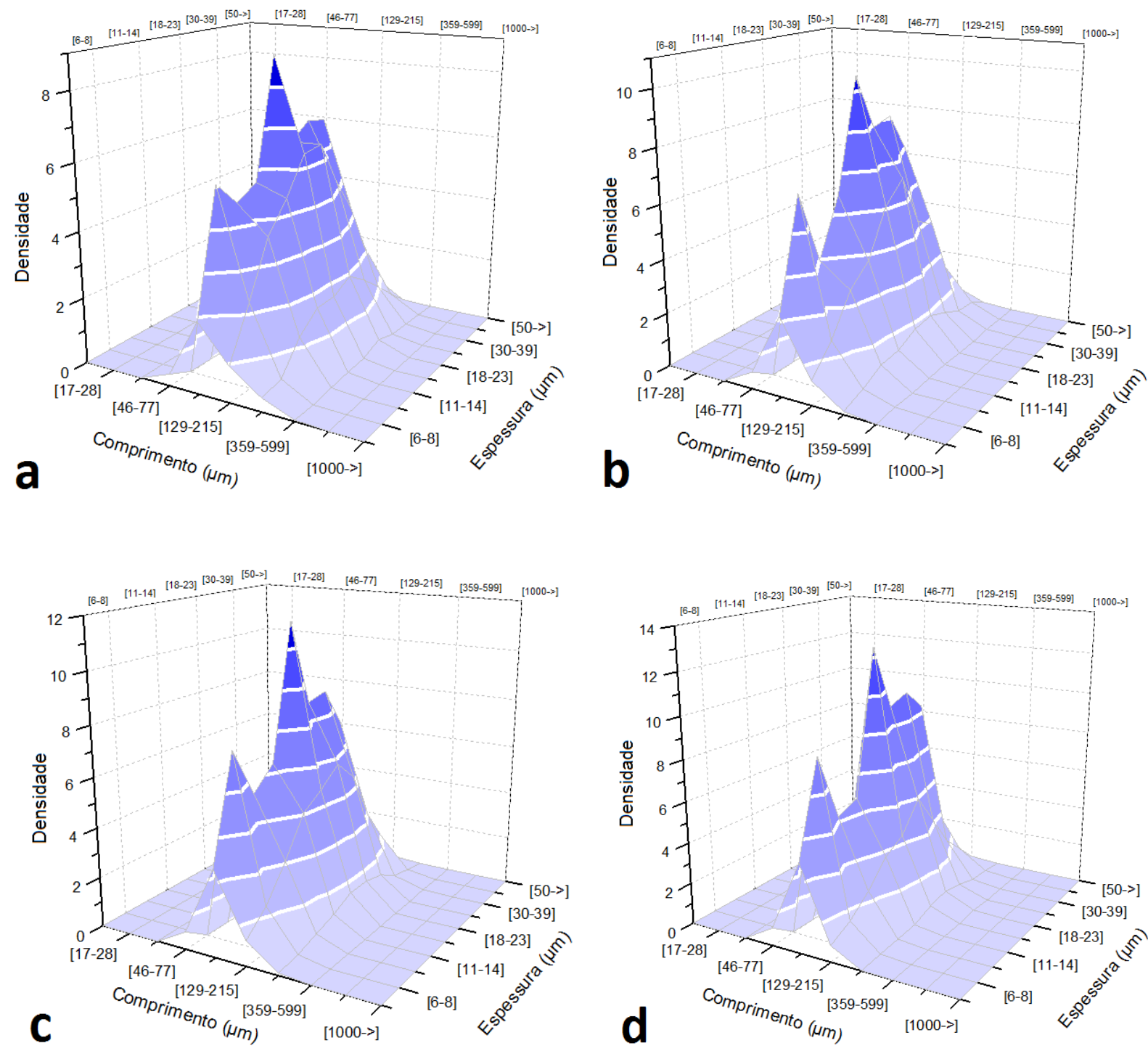

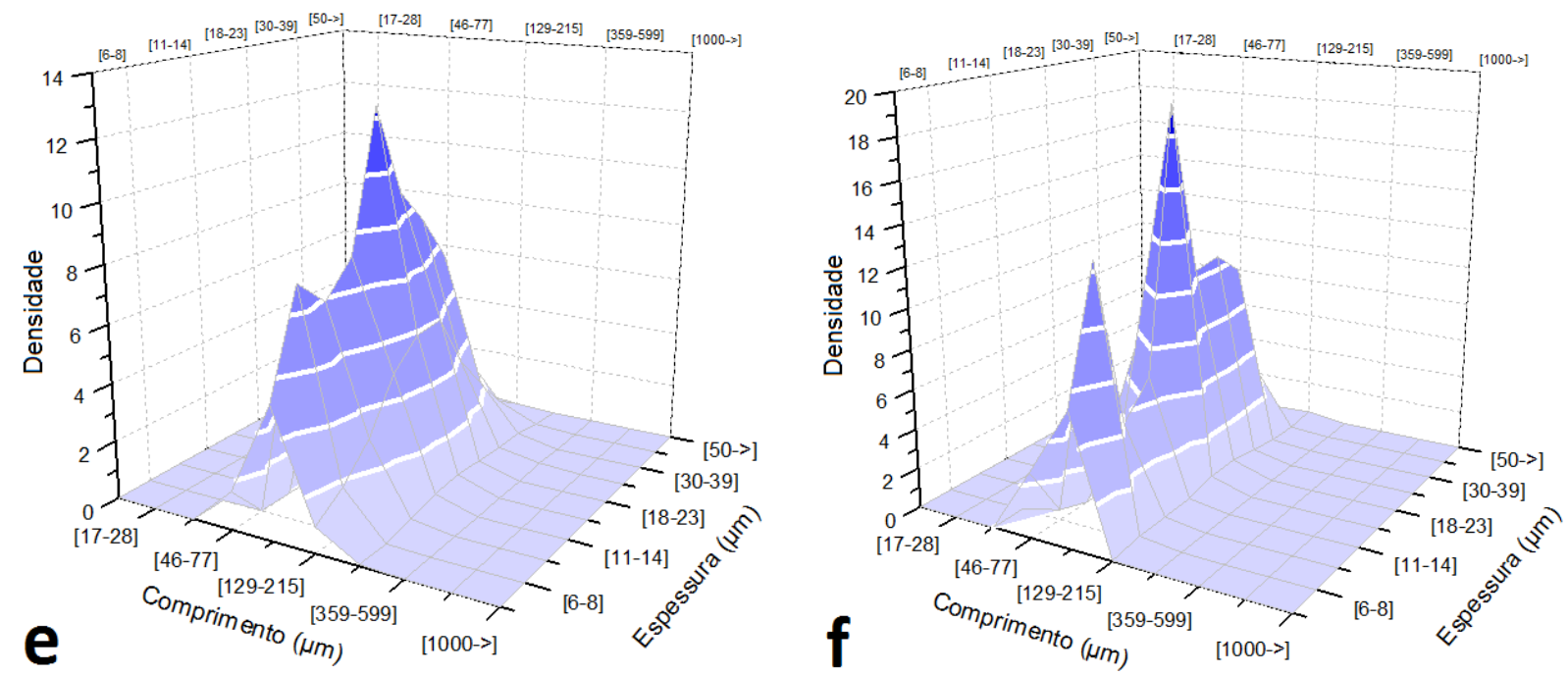

Figura 41 - Mapas de densidade referentes às polpas residuais das reações de hidrólise com polpa

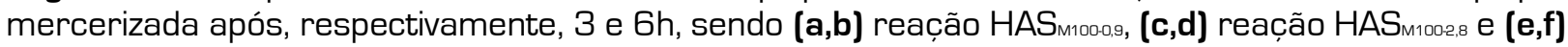
reação HAS $1004,4$.

A distribuição do comprimento médio das fibras tende a sofrer um deslocamento no sentido dos menores comprimentos [Figura 41] [maior densidade de fibras entre 46$129 \mu \mathrm{m}$, o que indica que maiores quantidades de fibras passaram a ter menores comprimentos], com o aumento do tempo e da concentração de ácido usada, indicando que o mecanismo de hidrólise ácida ocorre preferencialmente pelas extremidades das fibras, visto que tal comportamento não é tão evidente quando se observa a evolução da espessura das fibras com o aumento do tempo e da concentração de ácido usada [espessura das fibras se mantém na região entre 11 e $23 \mu \mathrm{m}$ ].

Para um maior detalhamento dos tamanhos de partículas possíveis de serem gerados via hidrólise, foi utilizado o espalhamento de luz [FOQELS], que possui limite máximo de detecção abaixo do apresentado pelo MorFi [2000 nm], ou seja, com este equipamento é possível detectar as partículas que estão em escala nanométrica. $\mathrm{Na}$ Figura 42 encontram-se as respectivas distribuições de tamanho em função da quantidade de partículas, para as polpas residuais das cinco reações com diferentes concentrações de ácido sulfúrico, após 6h. 


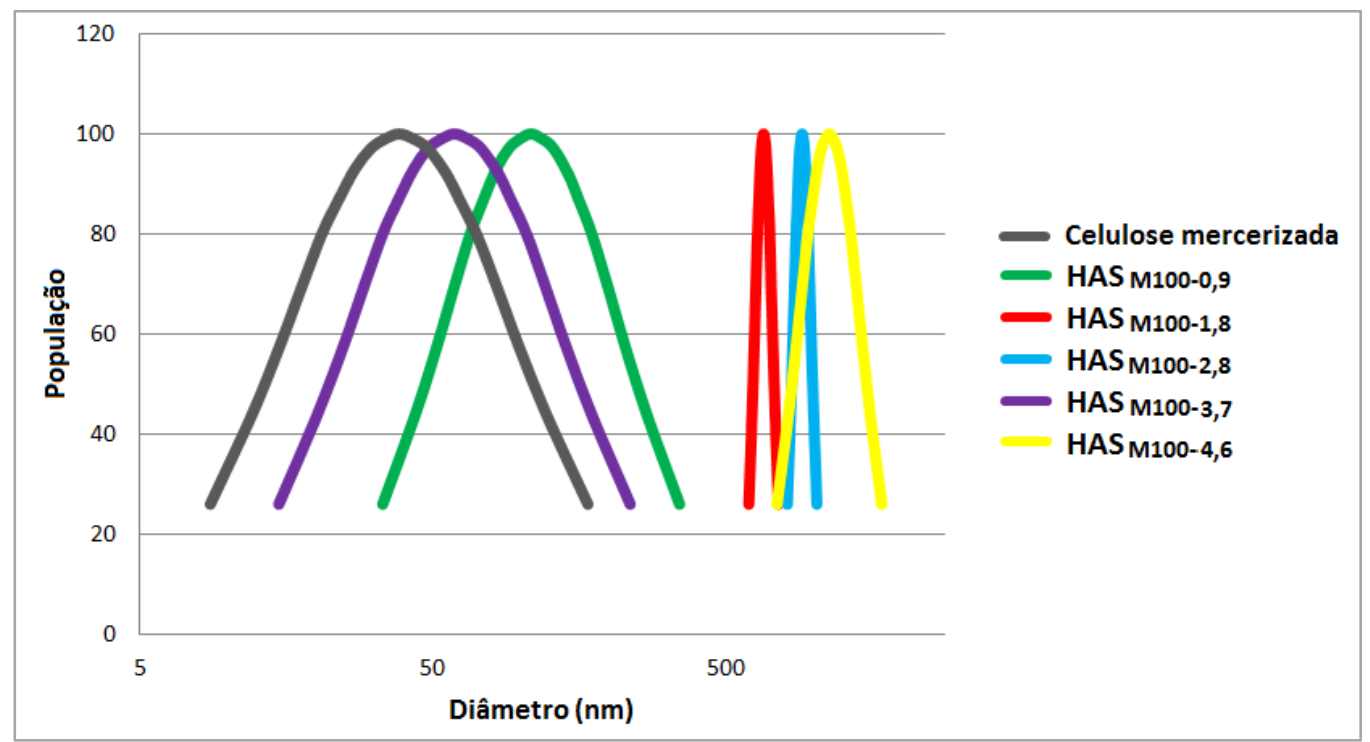

Figura 42 - Distribuição média dos tamanhos de partículas detectadas por espalhamento de luz.

Em todas as reações estudadas, mesmo naquelas com baixas concentrações de ácido, foi possivel identificar a presença de partículas em escala nanométrica após 6h, o que é um excelente resultado, visto que estas partículas podem possuir uma vasta gama de aplicações em materiais baseados em fontes renováveis. 0 valor obtido para a polpa de partida não mercerizada (na ordem de 60000 nm] não foi inserido nesta figura, pois este está muito acima do limite máximo de detecção [com precisão] do aparelho. Entretanto, este é um indicativo de que a polpa não mercerizada não possui partículas na ordem de nanômetros. Durante a mercerização, ocorre a separação dos feixes de fibras e a eliminação de grande parte da hemicelulose que compõem a polpa, o que pode levar a diminuição das dimensões das fibras, fato que pode ser comprovado pela detecção de partículas em escala nanométrica através da análise de espalhamento de luz. É importante salientar que esta técnica não fornece as mesmas informações do MorFi [comprimento e espessura de fibras], e foi utilizada apenas para detectar a presença de partículas em escala nanométrica. 


\subsubsection{Caracterização dos produtos gerados nas reações de hidrólise}

Os açúcares e derivados que podem ser encontrados nos licores, formados nas reações de hidrólise, estão descritos na Tabela 5.

Tabela 5 - Natureza dos possíveis açúcares e derivados que podem ser encontrados nos licores obtidos nas reações de hidrólise de polpa celulósica.

\begin{tabular}{|c|c|c|c|c|c|}
\hline $\begin{array}{c}\text { Produtos da } \\
\text { hidrólise de } \\
\text { celulose }\end{array}$ & $H A S_{\text {моо-о, }}$ & $H A S_{\text {м100-1,8 }}$ & $H A S_{\text {M100-2,8 }}$ & $H A S_{\text {м100-3,7 }}$ & $H A S_{M 100-4,6}$ \\
\hline Glicose & $x$ & $x$ & $x$ & $x$ & $x$ \\
\hline HMF & $x$ & $x$ & $x$ & $x$ & $x$ \\
\hline Ácido fórmico & $\varnothing$ & $\varnothing$ & $x$ & $x$ & $x$ \\
\hline $\begin{array}{c}\text { Produtos da } \\
\text { hidrólise de } \\
\text { hemiceluloses }\end{array}$ & $H A S_{\text {моо-о, }}$ & $H A S_{\text {м100-1.8 }}$ & $H A S_{\text {м100.2,8 }}$ & $H A S_{\text {м100-3.7 }}$ & $H A S_{M 1004,6}$ \\
\hline Xilose & $x$ & $x$ & $x$ & $x$ & $x$ \\
\hline Ácido acético & $\varnothing$ & $\varnothing$ & $\varnothing$ & $\varnothing$ & $\varnothing$ \\
\hline Arabinose & $\varnothing$ & $\varnothing$ & $\varnothing$ & $\varnothing$ & $x$ \\
\hline Furfural & $x$ & $x$ & $\mathrm{x}$ & $x$ & $x$ \\
\hline
\end{tabular}

Da mesma maneira que foi observado quando as reações foram realizadas com polpa sem tratamento, para todas as condições de hidrólise houve formação de glicose, ou seja, todas as condições levaram à clivagem das ligações 1,4-ß-glicosídicas das cadeias de celulose, diferindo na extensão em que ocorreram.

O ácido acético é proveniente da hidrólise dos grupos acetila das hemiceluloses, e se presente, estava em concentração abaixo do limite mínimo de detecção do equipamento utilizado. Ácido fórmico, proveniente da decomposição de HMF [Equação 1), não foi detectado para as reações com 0,9 e 1,8 $\mathrm{molL}^{-1} \mathrm{H}_{2} \mathrm{SO}_{4}$ pelo mesmo motivo.

A arabinose foi detectada apenas para as amostras dos licores provenientes da reação $\mathrm{HAS}_{\text {м1004,6. }}$ Tendo em vista o baixo teor de hemiceluloses na polpa mercerizada [Tabela 1] e o baixo teor de arabinose nas hemiceluloses [Figura 10], era esperado que este açúcar não fosse detectado para as reações realizadas com concentrações mais baixas de ácido. 
As Figuras de $\mathbf{4 3}$ a $\mathbf{4 6}$ são referentes à formação dos produtos provenientes da hidrólise direta da celulose [glicose], e da decomposição da glicose [HMF e ácido fórmico].

A Figura 43 mostra as curvas de concentração de glicose em função do tempo de reação para todas as concentrações de ácido sulfúrico consideradas.

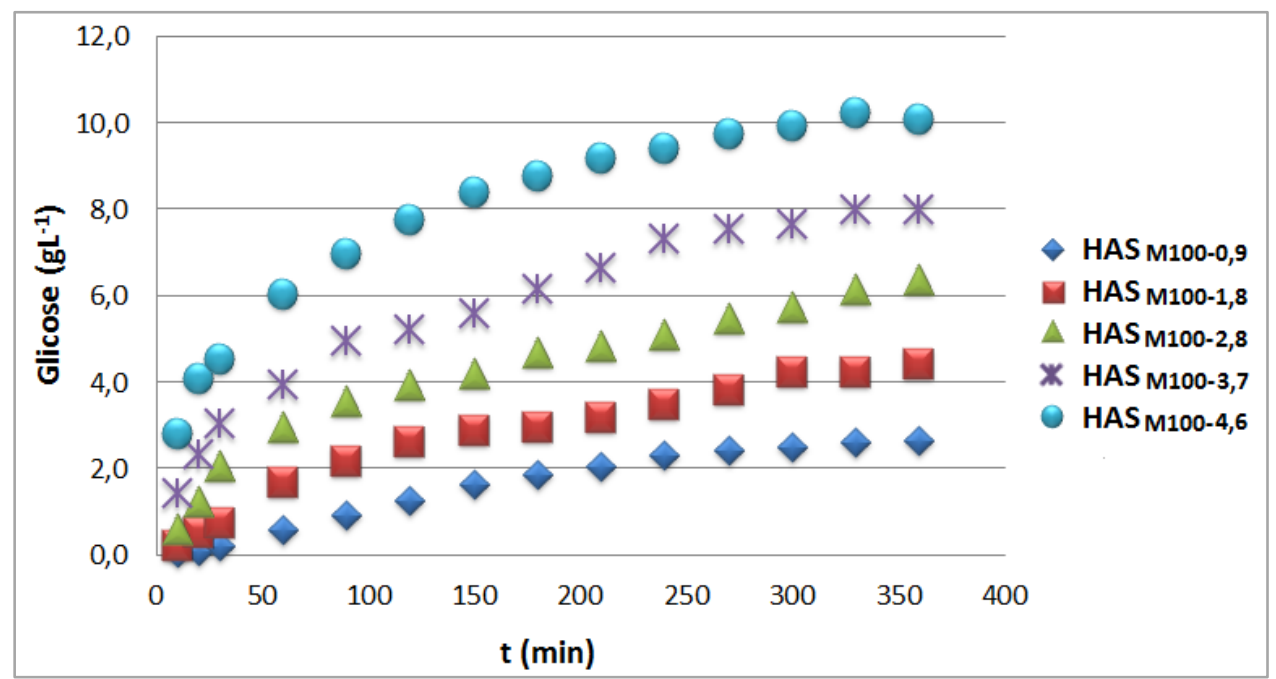

Figura 43 - Concentração de glicose em função do tempo para as reações com diferentes concentrações de ácido $\left[100^{\circ} \mathrm{C}\right]$.

Observa-se que a produção de glicose está diretamente relacionada à concentração de ácido usada, conforme esperado, sendo que o valor máximo obtido foi maior que $11 \mathrm{gL}^{-1}$ após 350 min de reação usando ácido sulfúrico 4,6 molL-1. Entretanto, após este intervalo de tempo, ocorre sutil decomposição da glicose a HMF [Equação 1], observando-se uma tendência frente à diminuição do valor de sua concentração no licor. Além disso, quando se compara a produção de glicose para as reações partindo de polpa de sisal mercerizada com aquelas partindo de polpa de sisal sem tratamento (Figura 32), nota-se um aumento de aproximadamente 50\% na concentração final de glicose quando a polpa mercerizada é usada, evidenciando a necessidade de pré-tratamentos que visam à eliminação de hemiceluloses e à diminuição do índice de cristalinidade da polpa de partida. 
Na Figura 44 estão inseridas as curvas de glicose potencial referentes às reações partindo de polpa de sisal mercerizada. Os valores de glicose potencial foram calculados conforme descrito para as reações partindo de polpa de sisal sem tratamento [Seção “Anexos” - Capítulo 5].

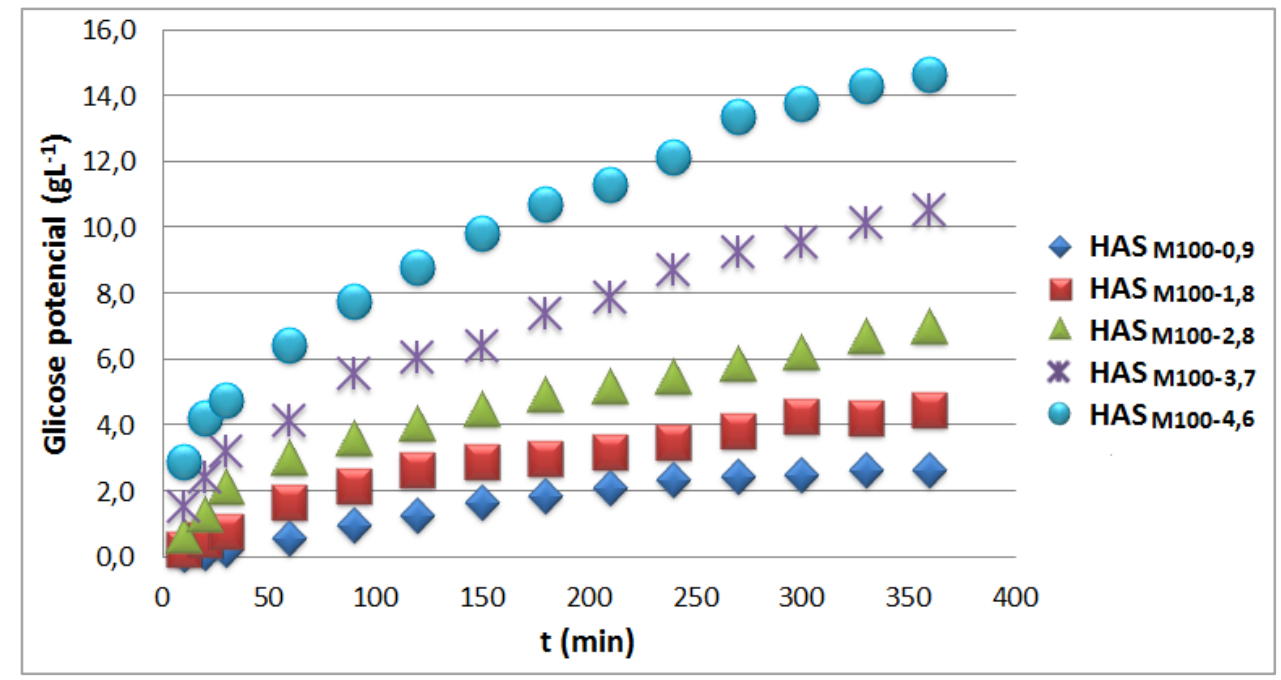

Figura 44 - Concentração de glicose potencial em função do tempo de hidrólise e da concentração de ácido.

Nota-se que a concentração hipotética de glicose, que pressupõe a não conversão desta a HMF e ácido fórmico [glicose potencial], é consideravelmente maior do que a concentração de glicose detectada, de fato, no licor contendo o material hidrolisado. Esta diferença chega a aproximadamente $45 \%$ para $t=360$ min no caso da reação

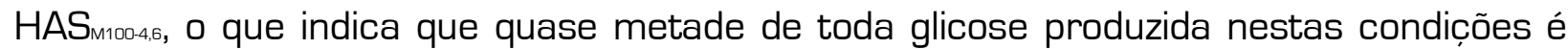
convertida a produtos de decomposição.

A presença de HMF em todas as amostras analisadas [Tabela 5] indica que todas as condições de reação levaram à decomposição parcial de glicose via reação de desidratação. A Figura 45 mostra as concentrações de HMF detectadas nas reações estudadas. 


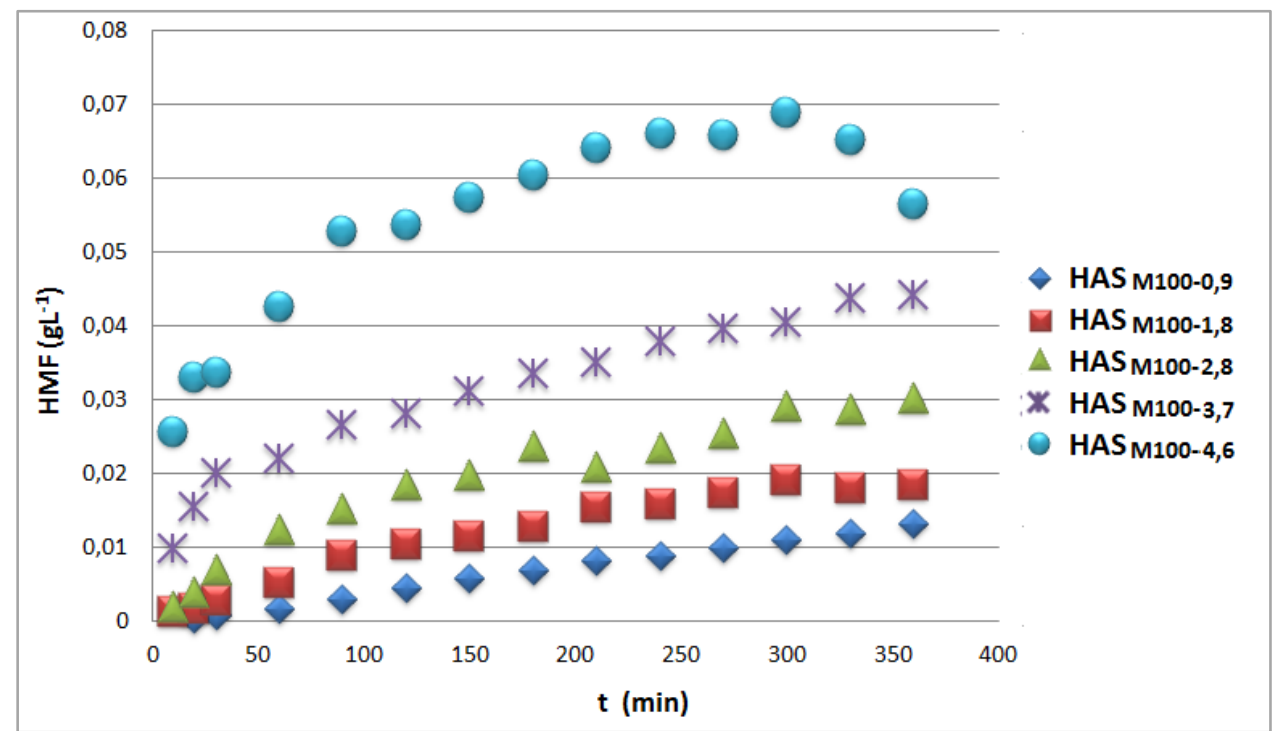

Figura 45 - Concentração de HMF no licor em função do tempo de hidrólise.

Observa-se que o aumento da concentração de ácido favoreceu a desidratação da glicose, acarretando em aumento da produção de HMF (Figura 45]. Nota-se que em HAS $_{\text {M100-o, }}$ praticamente não há formação de HMF, e apenas a partir de 120 min de reação é observado uma pequena fração $\left[0,005 \mathrm{gL}^{-1}\right]$. Em contrapartida, em HAS ${ }_{\text {м100-4,6 }}$ o valor da concentração de HMF chega a quase 0,055 $\mathrm{gL}^{-1}$, neste mesmo intervalo de tempo.

O ácido fórmico foi detectado apenas para as concentrações de $\mathrm{H}_{2} \mathrm{SO}_{4}$ entre 2,8 e 4,6 molL-1. A Figura 46 mostra a evolução da concentração de ácido fórmico no licor em função do tempo para as reações $\mathrm{HAS}_{\text {m1002,8, }} \mathrm{HAS}_{\text {м1003,7, }}$ e $\mathrm{HAS}_{\text {м1004,6. }}$ 


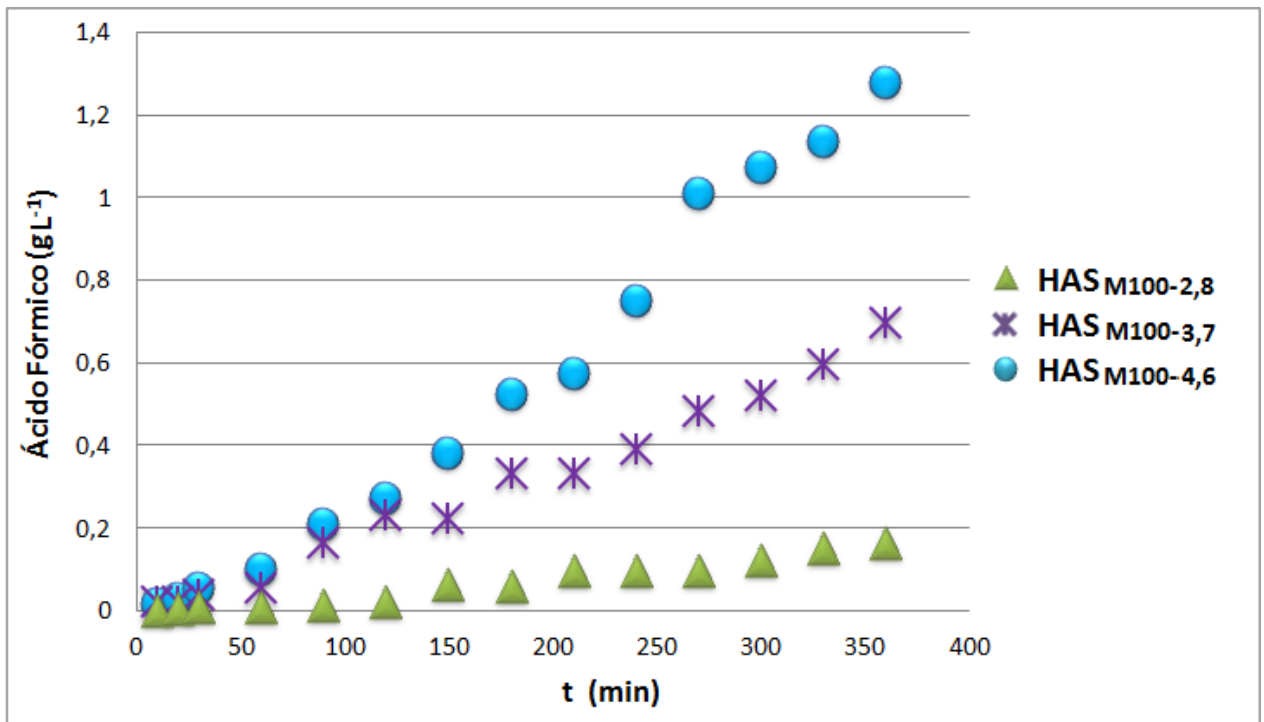

Figura 46 - Concentração de ácido fórmico no licor em função do tempo de hidrólise.

É possível notar que, com exceção de $\mathrm{HAS}_{\text {м1002, }}$ é grande a diferença de concentração de ácido fórmico em relação ao HMF [Figura 45 e 46]. Este fato é justificado, pois a estabilidade do HMF nestas condições é extremamente baixa, levando à formação de ácido fórmico e levulínico [não analisado, devido não disponibilidade de padrão para análise via CLAE].

As Figuras de $\mathbf{4 7}$ a $\mathbf{4 9}$ são referentes à formação dos produtos provenientes da hidrólise das hemiceluloses, ou seja, xilose, arabinose e furfural.

A Figura 47 mostra a variação da concentração de xilose no licor, para reações realizadas a $100^{\circ} \mathrm{C}$, com concentração de $\mathrm{H}_{2} \mathrm{SO}_{4}$ variando entre 0,9 e 4,6 molL-1. 


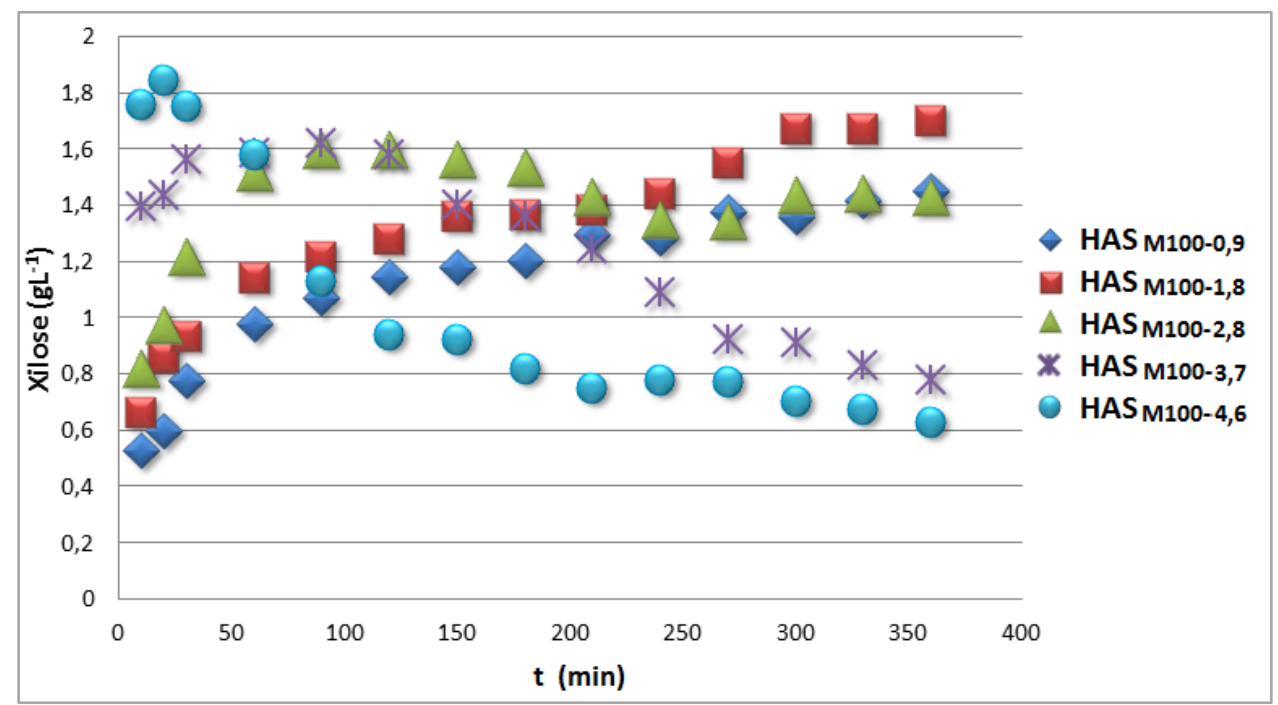

Figura 47 - Concentração de xilose no licor em função do tempo de hidrólise.

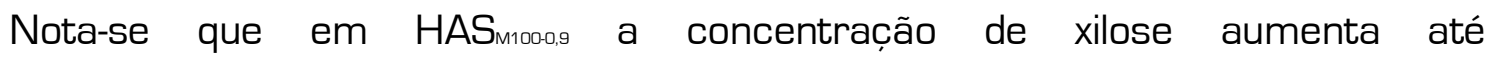
aproximadamente 250 min, mantendo-se constante depois. Um comportamento similar é observado para $\mathrm{HAS}_{\text {м100-1,8. }}$ Em $\mathrm{HAS}_{\mathrm{M1002.8}}$ e $\mathrm{HAS}_{\mathrm{M1003,7}}$ este aumento ocorre até aproximadamente 90 min, mas com decomposição a partir daí. Por outro lado, para HAS $_{\text {M00-4, }}$ se tem altas concentrações de xilose já nos 10 min iniciais de reação, ocorrendo decomposição na sequência, conforme evidenciado pela diminuição de sua concentração. Estes resultados indicam que a $100^{\circ} \mathrm{C}$ a xilose é relativamente estável a concentrações de $\mathrm{H}_{2} \mathrm{SO}_{4}$ entre 0,9 e 2,8 $\mathrm{molL}^{-1}$, mas altamente instável a partir de 3,7 molL-1.

A Figura 48 mostra as concentrações de arabinose no licor em função do tempo

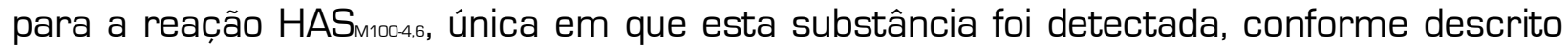
na Tabela 5. 


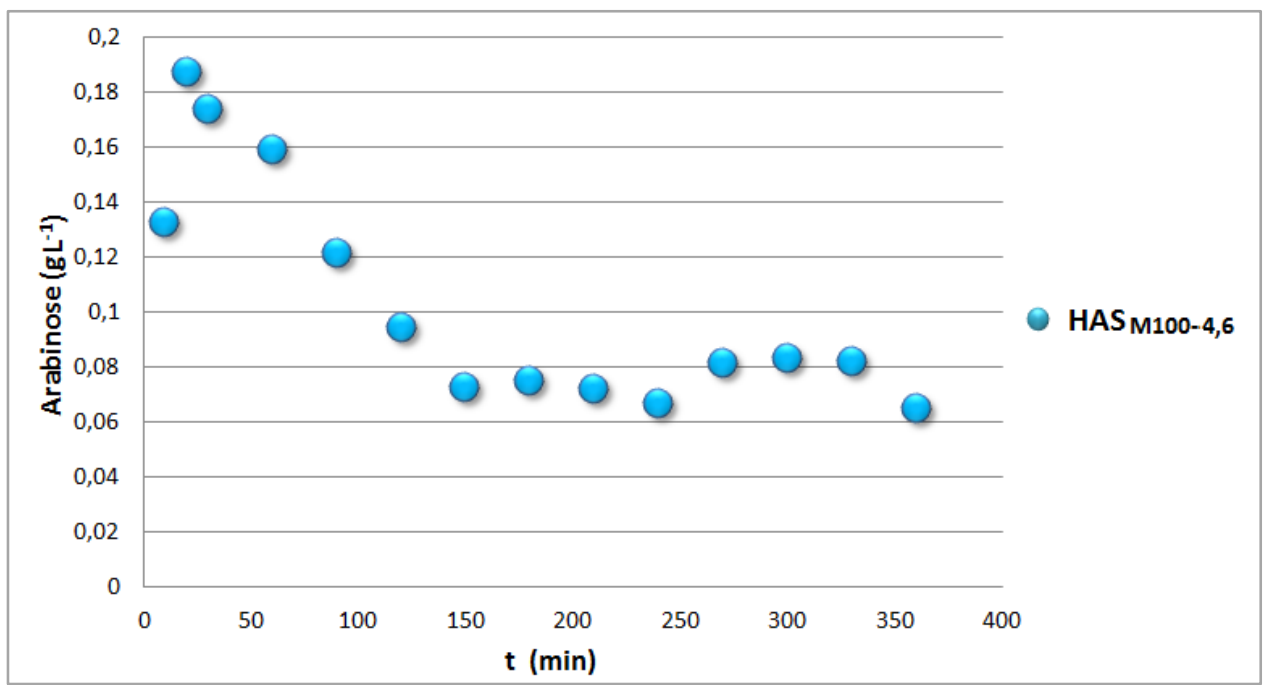

Figura 48 - Concentração de arabinose no licor em função do tempo de hidrólise.

Mesmo em pequena concentração, a arabinose é bastante instável frente a grandes quantidades de ácido, justificado pelo pico inicial em 20 min, quando a concentração chega a quase $0,2 \mathrm{gL}^{-1}$, seguido de um nítido decréscimo até 150 min, quando chega a aproximadamente $0,07 \mathrm{gL}^{-1}$ e segue aproximadamente constante até 0 final da reação.

Em relação aos açúcares que foram encontrados no licor, provenientes de hemiceluloses [xilose e arabinose], todas as condições reacionais levaram à decomposição dos mesmos, fato comprovado pela presença de furfural em todos os licores obtidos, conforme ilustrado pela Figura 49. 


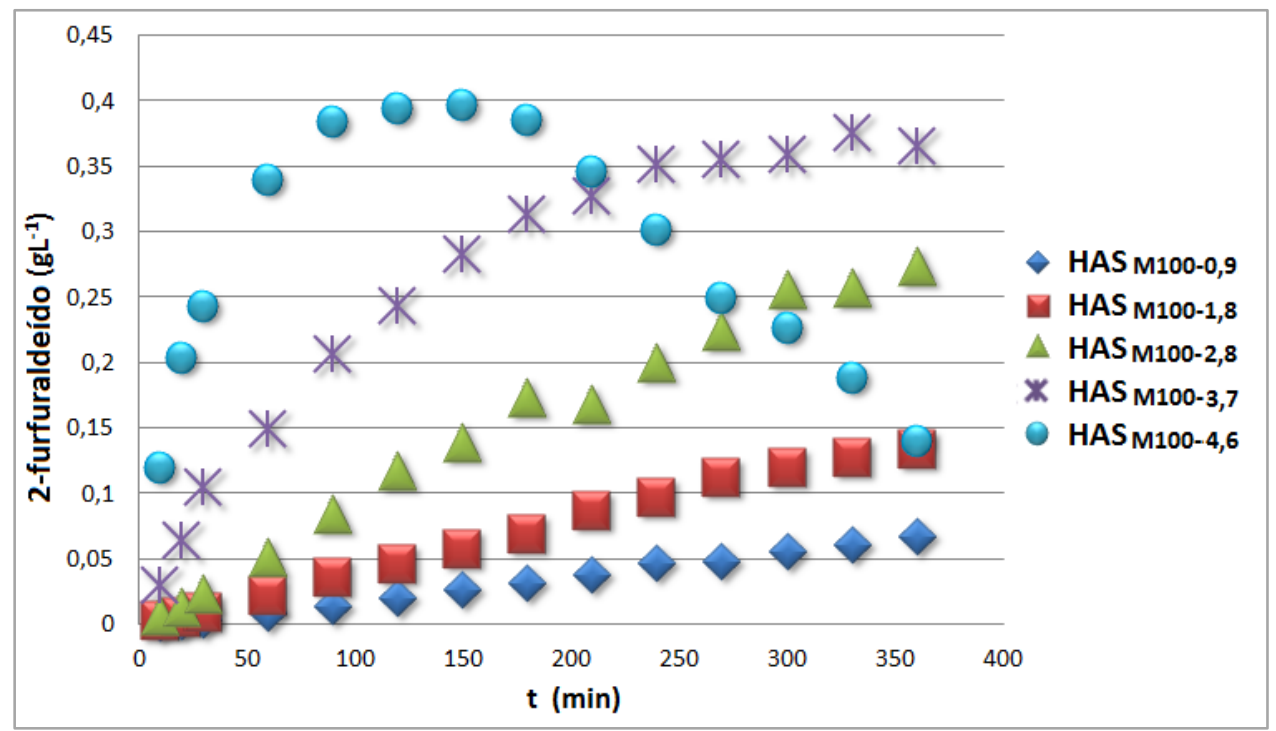

Figura 49 - Concentração de furfural no licor em função do tempo de hidrólise.

Observa-se que a $100^{\circ} \mathrm{C}$, o aumento da concentração de ácido de 0,9 para 4,6 molL-1 levou a um considerável aumento da produção de furfural no meio reacional (Figura 49). Ainda, observando o perfil das curvas, nota-se que $\mathrm{HAS}_{\text {m1004,6 }}$ alcançou um limite máximo de concentração em t $=150$ min e a partir daí a taxa de formação é menor que a de decomposição, e as concentrações começam a declinar até que, após Gh de reação, este valor é consideravelmente menor que o máximo atingido. Este fato provavelmente está relacionado à formação de produtos de condensação, favorecida a $100^{\circ} \mathrm{C}$ [Figura 31-b].

Os gráficos a seguir mostram o ajuste não-linear do modelo de Saeman [Equação 6) para as curvas de concentração de glicose em função da concentração de ácido.

Para que o modelo fosse aplicado às curvas experimentais de concentração de glicose, o software OriginPro 8 SRO versão 8.0724 [B724] foi utilizado. Através da ferramenta de ajuste não linear do software, os dados puderam ser ajustados ao modelo. Para isso, na Equação 6, que descreve o modelo, foram inseridos os valores de concentração de glicose $[[B]]$, para cada tempo $[\mathrm{t}]$ partindo-se de um valor de concentração de celulose inicial $\left[[A]_{0}\right]$ para que os valores das constantes $\left[k_{1}\right.$ e $\left.k_{2}\right]$ fossem 
calculados em cada condição estudada. A concentração de celulose na polpa de partida [expressa em $\mathrm{gL}^{-1}$ ] foi calculada considerando a massa da polpa adicionada ao reator, conforme descrito na parte experimental, e o teor de $\alpha$-celulose na polpa (Tabela 1). A glicose gerada pela hidrólise da hemicelulose não foi considerada isoladamente, por se tratar de quantidade não significativa, conforme já mencionado.
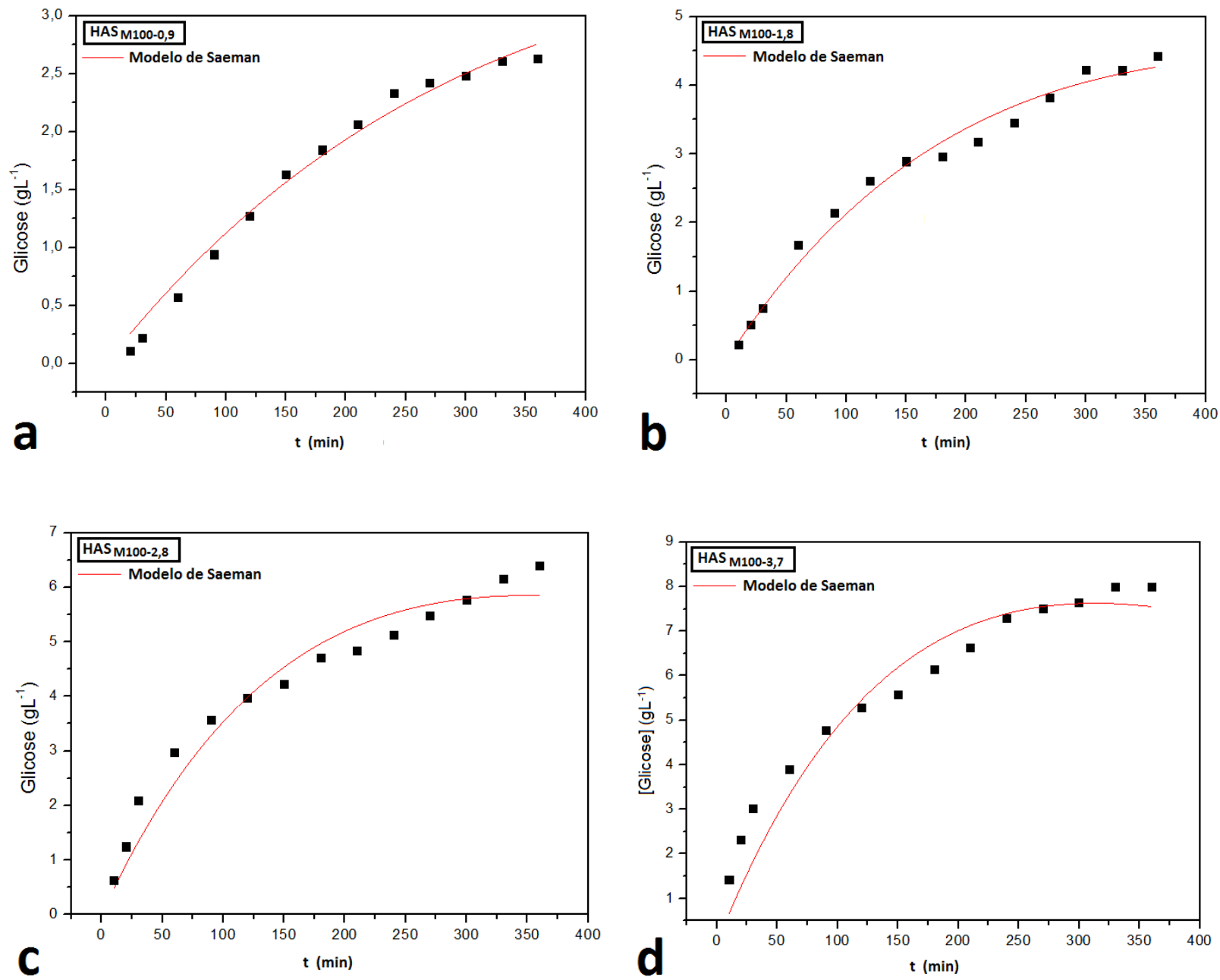


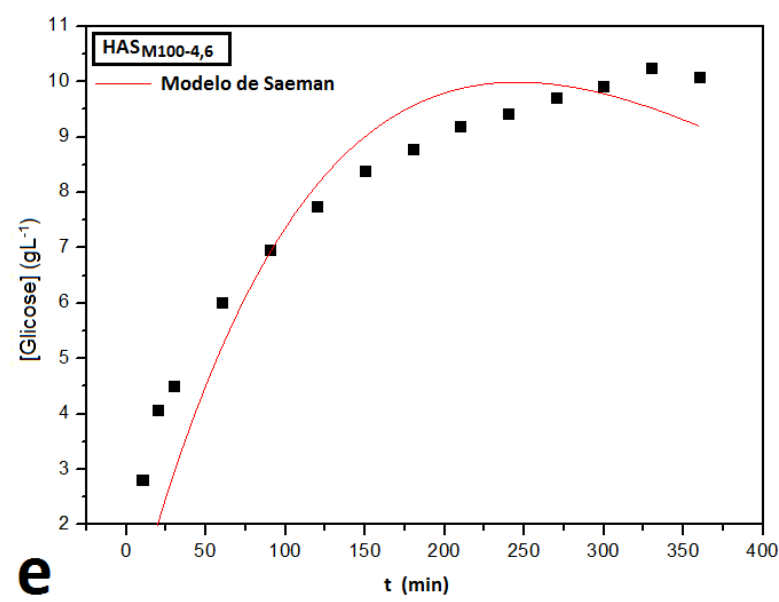

Figura 50 - Ajuste não-linear do modelo de Saeman para hidrólise ácida de celulose a $100^{\circ} \mathrm{C}$, com diferentes concentrações de ácido, sendo [a] 0,9 $\mathrm{molL}^{-1}$, (b) 1,8 $\mathrm{molL}^{-1}$, (c) 2,8 $\mathrm{molL}^{-1}$, [d] 3,7 $\mathrm{molL}^{-1} \mathrm{e}$ [e] $4,6 \mathrm{molL}^{-1}$.

Os valores das constantes de velocidade [ $k_{1}$ e $k_{2}$, Equação 1] para as reações estudadas, bem como os respectivos valores de $\mathrm{R}^{2}$, que corresponde ao ajuste dos dados ao modelo utilizado, estão expressos na Tabela 6.

Tabela 6 - Constantes de hidrólise de celulose [ $\left.k_{1}\right]$, decomposição de glicose [ $\left.k_{2}\right]$ e valor de $\mathrm{R}^{2}$.

\begin{tabular}{|c|c|c|c|c|c|}
\hline & HAS $_{\text {м100-0,9 }}$ & HAS $_{\text {м100-1,8}}$ & HAS $_{M 100-2,8}$ & HAS $_{\text {м1003,7 }}$ & HAS $_{M 100-4,6}$ \\
\hline $\mathrm{k}_{1} \times 10^{3}$ & 0,4 & 0,8 & 1,3 & 2,2 & 3,6 \\
\hline$k_{2} \times 10^{3}$ & 2,8 & 4,2 & 5,2 & 4,5 & 4,6 \\
\hline $\mathrm{R}^{2}$ & 0,986 & 0,987 & 0,946 & 0,915 & 0,813 \\
\hline
\end{tabular}

Os valores de $\mathrm{R}^{2}$ mostrados na Tabela $\mathbf{6}$ indicam que os dados experimentais se ajustam razoavelmente bem ao modelo de Saeman, com exceção da reação HAS ${ }_{\text {м1004,6, }}$ para a qual o valor de $R^{2}$ é 0,813 . Os valores de $k_{1}$ e $k_{2}$ mostram que para todas as concentrações de ácido consideradas, a constante de velocidade da reação de decomposição é maior que a de formação de glicose. Para a menor e maior concentração de ácido [0,9 e 4,6 molL $\left.{ }^{-1}\right], k_{2} / k_{1}$ é aproximadamente igual a 7,8 e 1,3 respectivamente, sendo que a dependência deste fator com a concentração de ácido é linear e sempre decrescente [Figura 51-c]. Observa-se que para a maior concentração 
de ácido $\left[4,6 \mathrm{molL}^{-1}\right]$ a velocidade de produção de glicose aumenta consideravelmente, sendo aproximadamente dez vezes maior que o mesmo valor referente à reação com 0,9 molL-1 $\mathrm{H}_{2} \mathrm{SO}_{4}$, enquanto que a velocidade de decomposição de glicose se manteve na mesma ordem de magnitude, sendo apenas aproximadamente 1,5 vezes maior. A $100^{\circ} \mathrm{C}$, a decomposição da glicose foi menos sensível à variação da concentração de ácido sulfúrico [Figura 51-b] que a formação de glicose [Figura 51-a]. A despolimerização da celulose ocorre a partir de um sólido suspenso no meio reagente, e a decomposição da glicose ocorre em solução, o que leva a reações com características diferentes.
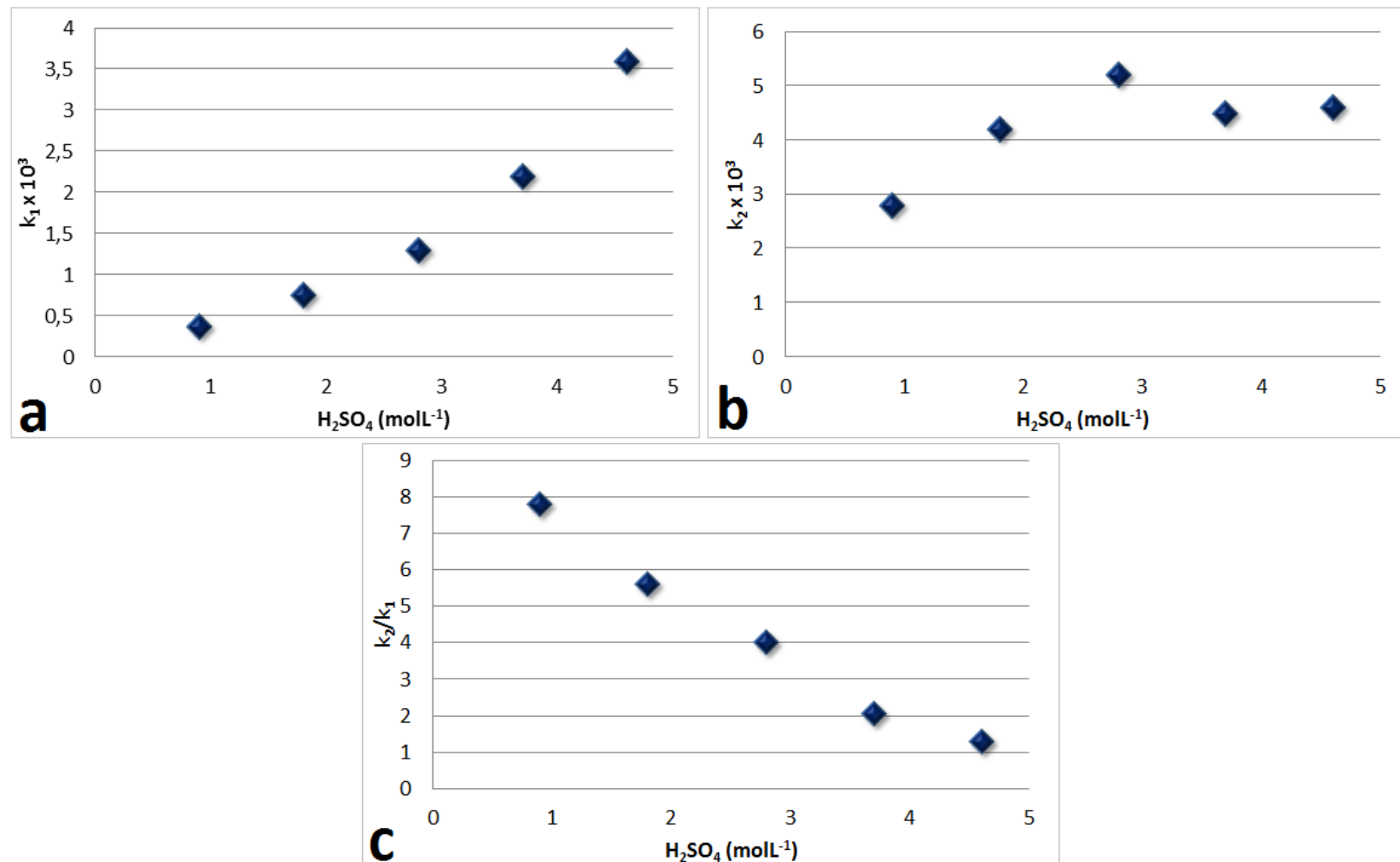

Figura 51 - Gráficos de [a] k1, [b] k2 e [c] k²/k1 em função da concentração de ácido sulfúrico utilizada. 


\section{AVALIAC̣ÃO DA INFLUÊNCIA DO TAMANHO MÉDIO DAS FIBRAS E DA CRISTALINIDADE DA POLPA DE PARTIDA}

Para a execução desta etapa do trabalho, foi escolhida a melhor condição entre as reações precedentes, ou seja, aquela que levou à maior produção de glicose. Sendo assim, as reações descritas a seguir foram conduzidas a $100^{\circ} \mathrm{C}, 4,6 \mathrm{moll}^{-1}$ de ácido sulfúrico e polpa de sisal previamente mercerizada.

Conforme descrito na seção 2.2.2.3, a polpa de celulose de sisal previamente triturada e mercerizada foi fracionada em um conjunto de peneiras Retsch AS 200 [Embrapa Pecuária Sudeste, São Carlos], com poros de $106 \mu \mathrm{m}, 75 \mu \mathrm{m}, 45 \mu \mathrm{m}$ e $25 \mu \mathrm{m}$, e foi possível fracionar a polpa em quatro grupos distintos, com tamanhos médios diferentes. Amostras provenientes de cada um destes grupos foram caracterizadas por difração de raios $X$, viscosimetria, e seus tamanhos médios foram medidos em um analisador de fibras [MorFi Compact - Techpap]. Os resultados destas análises estão descritos na Tabela 7, bem como os códigos que serão usados para referenciar cada grupo obtido por fracionamento.

Para fins de comparação, os resultados da reação $H A S_{\text {м1004,6, que foi executada }}$ nas mesmas condições de temperatura e concentração de ácido, serão inseridos aqui. Esta reação foi realizada partindo da polpa de sisal mercerizada sem fracionamento, ou seja, corresponde a uma "mistura de tamanhos". 
Tabela 7 - Códigos usados para denominar as reações estudadas $\left[100^{\circ} \mathrm{C}, 4,6\right.$ molL $\left.^{-1} \mathrm{H}_{2} \mathrm{SO}_{4}\right]$, de acordo com as condições de fracionamento e cristalinidade da polpa de partida.

\begin{tabular}{|c|c|c|c|}
\hline Código & $\begin{array}{l}\text { Comprimento médio } \\
\text { das fibras }[\mu \mathrm{m}]\end{array}$ & $\begin{array}{c}\text { Índice de } \\
\text { cristalinidade [\%] }\end{array}$ & $\begin{array}{c}\mathrm{MM}_{\text {is }} \\
\text { [gmol'] }^{-1} \text { ) }\end{array}$ \\
\hline HAS $_{M 1004,6}$ & 238 & 69 & $99900 \pm 450$ \\
\hline HAS $_{\text {MF1 }}$ & 383 & 65 & $107000 \pm 300$ \\
\hline HAS $_{\text {MF2 }}$ & 313 & 72 & $112000 \pm 200$ \\
\hline $\mathrm{HAS}_{\mathrm{MF} 3}$ & 249 & 73 & $98000 \pm 350$ \\
\hline $\mathrm{HAS}_{\mathrm{M}=4}$ & 130 & 75 & $100000 \pm 300$ \\
\hline
\end{tabular}

Sendo "HAS" a abreviação de "hidrólise com ácido sulfúrico", M representa a polpa de partida [mercerizada], e F1-F4 correspondem às quatro frações de polpas obtidas por peneiramento.

Através dos resultados das análises das polpas obtidas por fracionamento, é possível observar que este procedimento foi eficiente, no sentido de que possibilitou a separação de materiais com diferentes propriedades. Deve-se destacar aqui a diferença entre os valores de índice de cristalinidade das polpas de diferentes comprimentos médios: a Fração 1, de fibras mais longas, apresentou I.igual a 65\%, enquanto a Fração 4 , de fibras mais curtas, possui $I_{0}$ igual a 75\%, o que é uma diferença considerável, principalmente para materiais que serão usados em reações em meio heterogêneo, como a hidrólise de celulose. As diferenças nos valores de massa molar média são pequenas, havendo uma leve tendência das fibras mais curtas possuírem menores valores de $\mathrm{MM}_{\text {is. }}$

A Figura 52 mostra as micrografias das polpas fracionadas obtidas por peneiramento. 

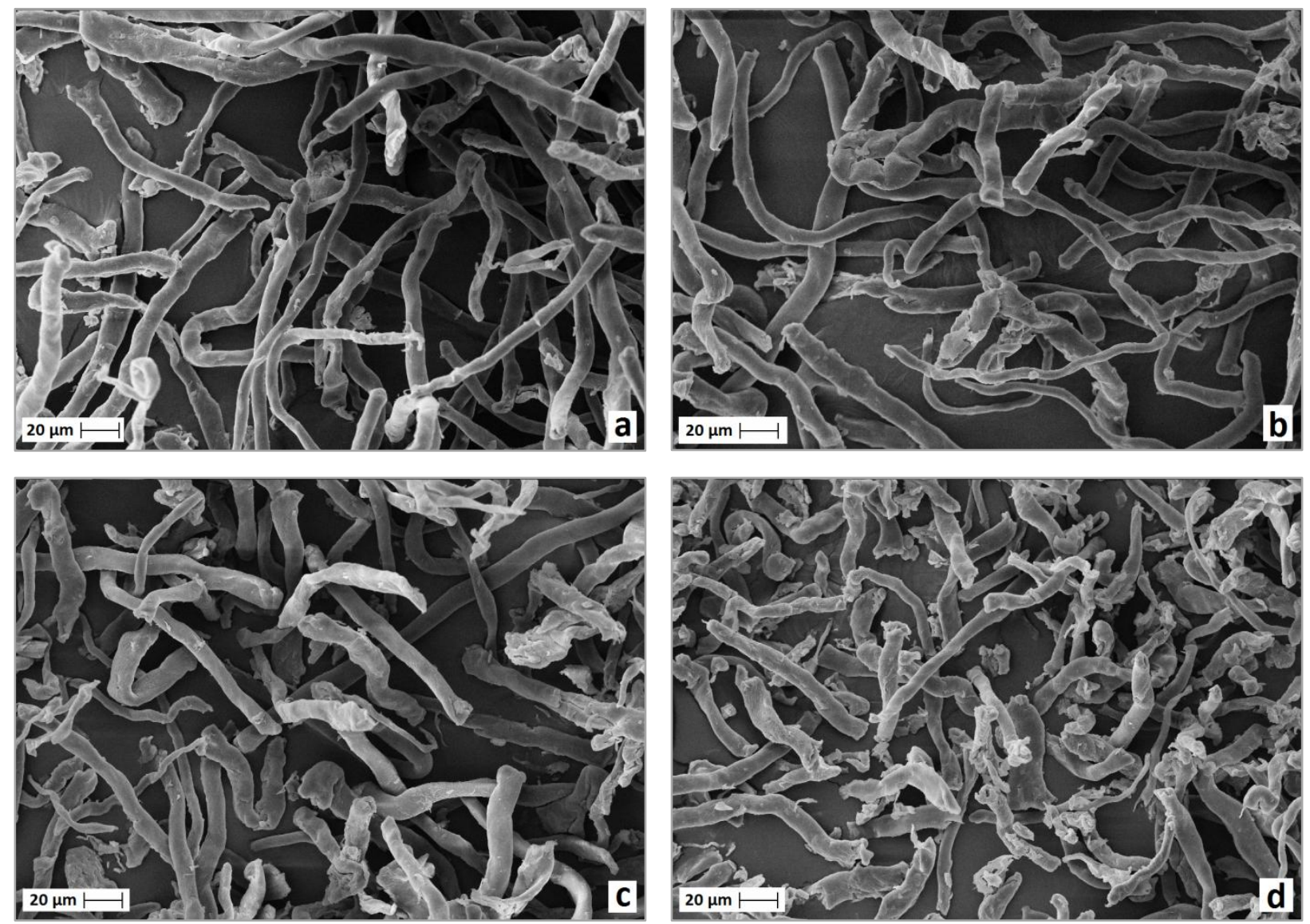

Figura 52 - Micrografias das polpas de partida, mercerizadas e separadas por peneiramento, sendo: [a] Fração 1, [b] Fração 2, [c] Fração 3 e [d] Fração 4.

Foram analisadas as modificações decorrentes da hidrólise ácida, tanto no licor contendo o material hidrolisado, quanto nas fibras residuais que não foram totalmente hidrolisadas, mesmo procedimento realizado para as reações descritas anteriormente.

\subsubsection{Caracterização da polpa residual}

Na Figura 53 estão mostrados os valores de massa molar média viscosimétrica e índice de cristalinidade das celuloses residuais após reações de hidrólise. 

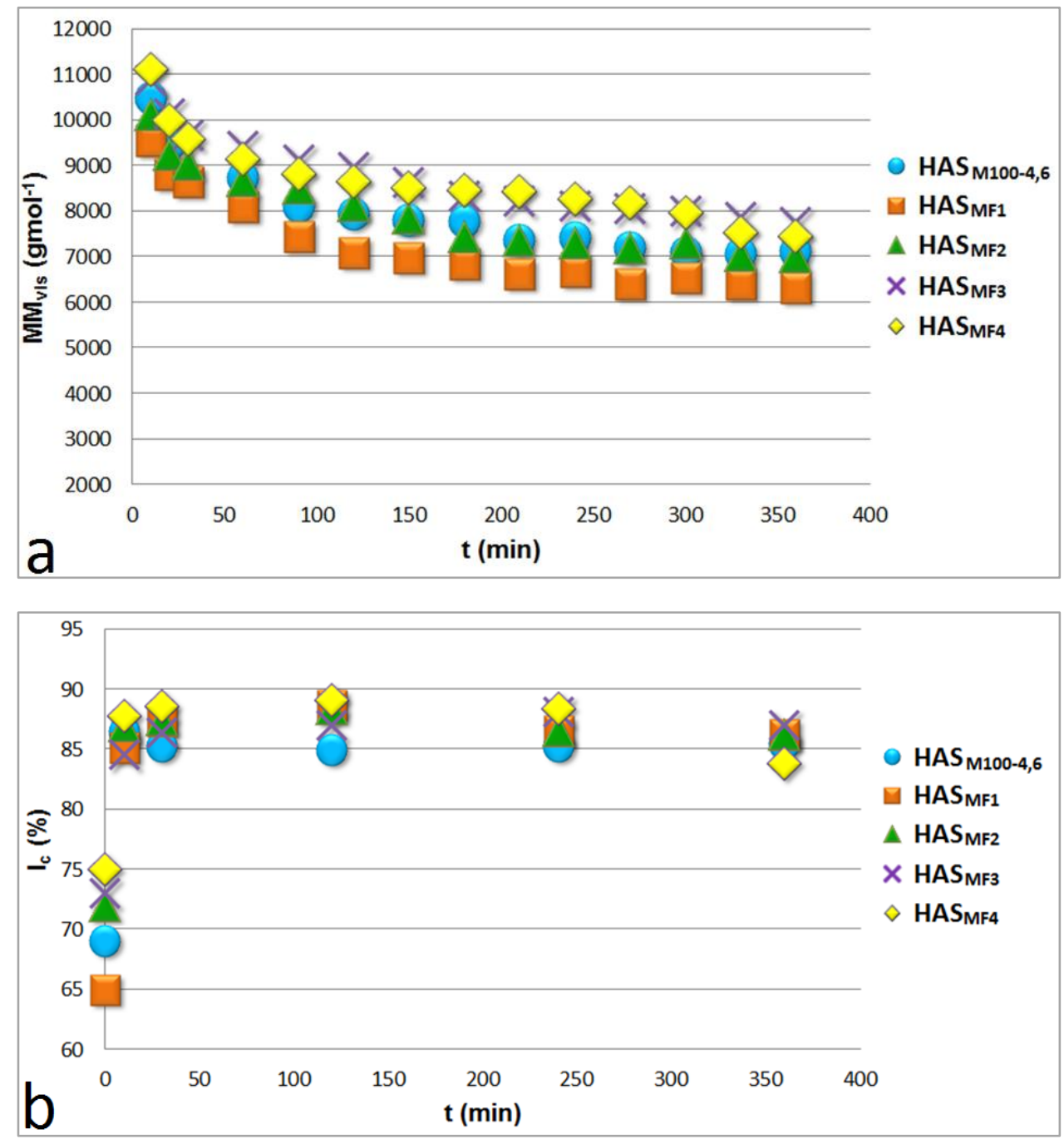

Figura 53 - Valores de [a] massa molar média viscosimétrica e [b] índice de cristalinidade das celuloses residuais das reações de hidrólise partindo de polpa mercerizada fracionada.

Nota-se pela Figura 53-a que, similarmente ao observado na Figura 26 e na Figura 38, os resultados mostraram que para todos os tamanhos de fibras usados, os valores de $\mathrm{MM}_{\text {is }}$ diminuíram consideravelmente quando comparados com os valores iniciais [polpa mercerizada não fracionada: $99900 \mathrm{gmol}^{-1}$, Fração 1: $107000 \mathrm{gmol}^{-1}$, Fração 2: 112000 gmol $^{-1}$, Fração 3: 98000 gmol $^{-1}$, Fração 4: 100000 gmol $^{-1}$ ], permanecendo aproximadamente constante após a queda inicial. As análises de difração de raios $X$ [Figura 53-b] mostraram, em todos os casos, um aumento inicial no índice de cristalinidade. Em seguida, todas as amostras sofreram diminuição de $\mathrm{I}_{\mathrm{c}}$ após este aumento inicial, com destaque para a polpa que possui fibras mais curtas [Fração 4], que 
apresentou uma diminuição mais pronunciada após 360 min de reação [l aproximadamente igual a 83\%], indicando que as regiões cristalinas foram mais facilmente acessadas nestas condições.

A Figura 54 mostra a variação dos domínios cristalinos das polpas residuais no decorrer dos experimentos em que se variou o tamanho médio das fibras $\left(\mathrm{H}_{2} \mathrm{SO}_{4} 4,6\right.$ $\left.\mathrm{molL}^{-1}, 100^{\circ} \mathrm{C}\right]$.

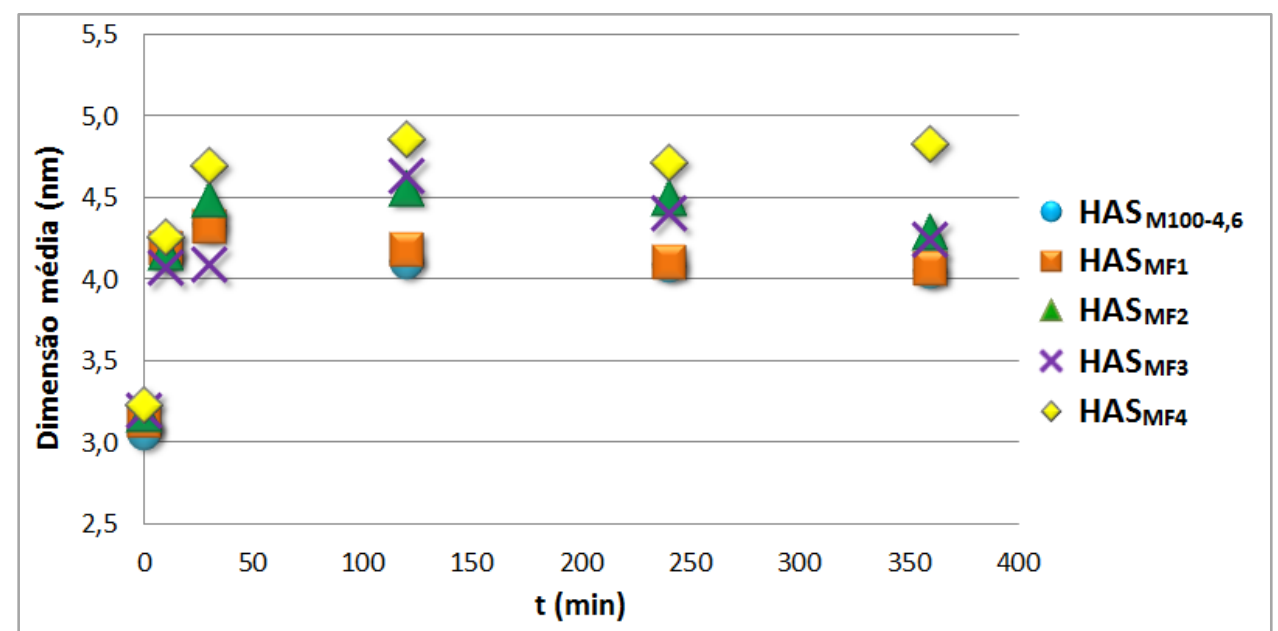

Figura 54 - Dimensão do plano 002 das polpas residuais das reações partindo de polpa mercerizada fracionada, em função do tempo de reação [ $100^{\circ} \mathrm{C}, 4,6 \mathrm{molL}^{-1} \mathrm{H}_{2} \mathrm{SO}_{4}$ ].

A variação das dimensões dos domínios cristalinos das diferentes frações de polpa [F1 - F4] segue um comportamento que se aproxima daquele observado para 0 índice de cristalinidade [Figura 53-b], sendo que provavelmente os mesmos efeitos mencionados previamente atuem neste caso. Entretanto, é importante destacar neste caso, as maiores dimensões médias dos cristalitos na polpa residual quando a fração F4 de menor tamanho médio foi usada como material de partida. Esse fato indica que o fracionamento possibilitou a separação de fibras de maior índice de cristalinidade e com maiores tamanhos médios dos domínios cristalinos. Observa-se que a Fração F1 [fibras mais longas] leva a uma diminuição acentuada nas dimensões após 360 min de reação [Figura 54]. Em todos os casos houve aumento das dimensões médias logo nos 
primeiros minutos de reação, sugerindo a reorganização de segmentos ou junções de domínios.

A Figura 55 mostra as micrografias das polpas residuais referente às reações realizadas com polpa mercerizada fracionada (Frações de 1 a 4 ], 4,6 molL $^{-1} \mathrm{H}_{2} \mathrm{SO}_{4}$ e $100^{\circ} \mathrm{C}$, após $240 \mathrm{~min}$.
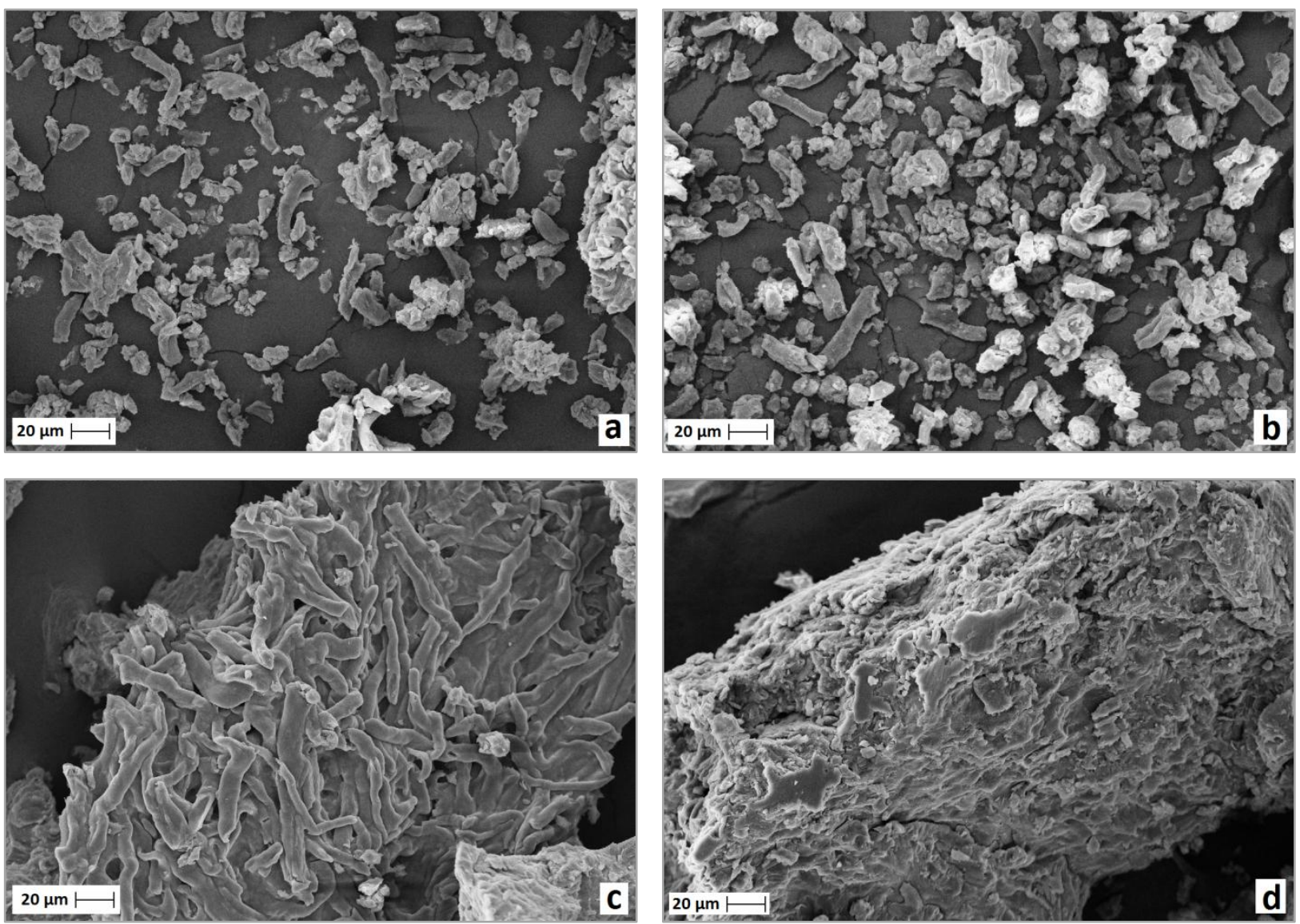

Figura 55 - Micrografias das polpas residuais, após 240 min, referentes às reações partindo das polpas fracionadas, sendo: [a] Fração 1, [b] Fração 2, [c] Fração 3 e [d] Fração 4.

Após 4h de reação envolvendo as Frações 1 e 2 [Figura 55-a,b], os feixes de fibras não reagidos se apresentaram fragmentados e com menores dimensões, quando comparadas com as fibras de partida [Figura 52-a,b]. Entretanto, observando as polpas residuais [não hidrolisadas] provenientes das reações com as Frações 3 e 4 [Figura 55c,d], realizadas nas mesmas condições de temperatura e concentração de ácido, nota-se que os feixes de fibras apresentaram uma tendência a se aglomerarem, formando um 
material compactado, similar ao mostrado na Figura 40-f, quando as mesmas condições reacionais foram usadas para a polpa que não passou por fracionamento [reação $\left.\mathrm{HAS}_{\mathrm{M} 1004,6}\right]$. Esta constatação indica que o uso de frações de fibras mais longas como material de partida [Frações 1 e 2] deve ser preferencial ao uso das frações com fibras mais curtas [Frações 3 e 4], quando o objetivo da reação é isolar as fibras residuais, não hidrolisadas, para serem subsequentemente aplicadas em biomateriais já que, neste caso, a aglomeração das fibras é geralmente indesejada.

A Figura 56 mostra os mapas de densidade [obtidos via equipamento MorFi Compact] referentes às medidas de tamanhos médios dos constituintes da polpa de celuloses não hidrolisadas durante as reações, para tempos iguais a 3 e 6h.
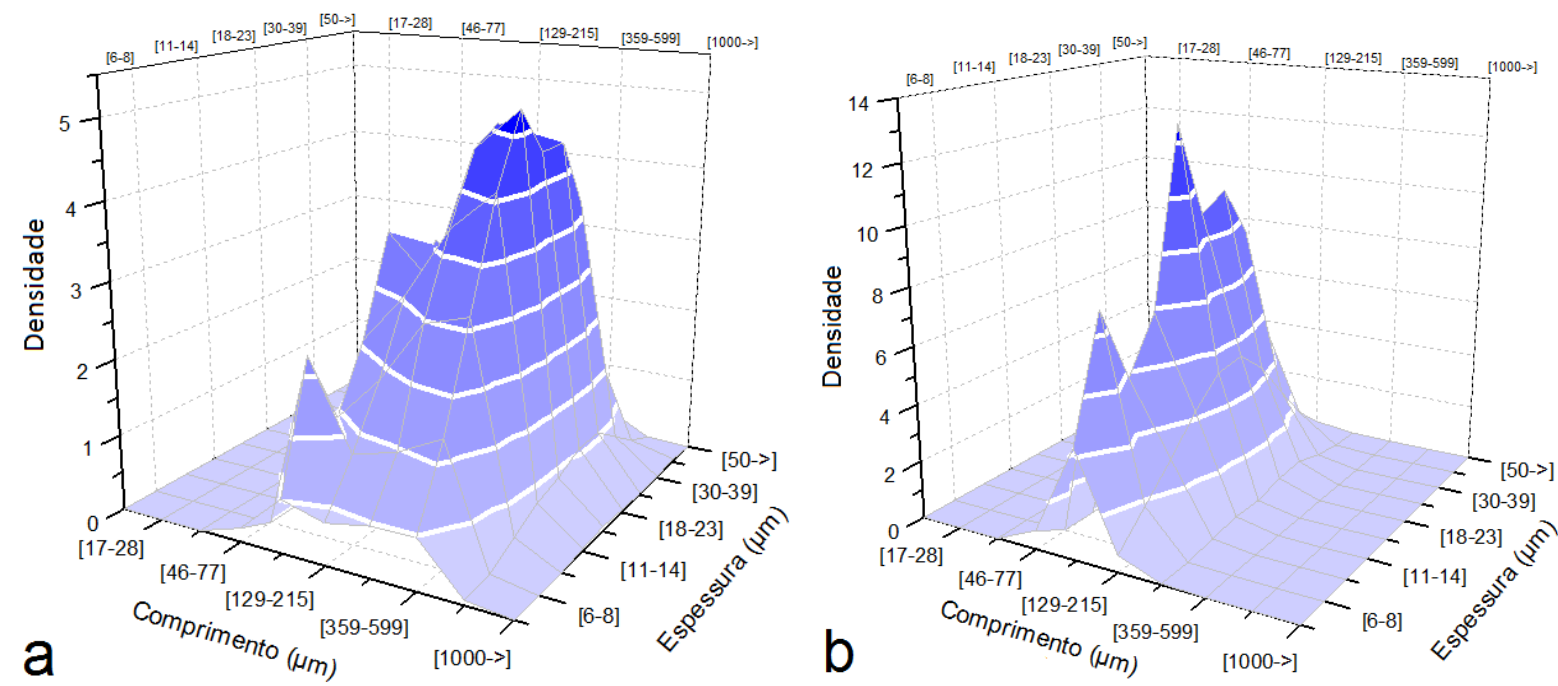

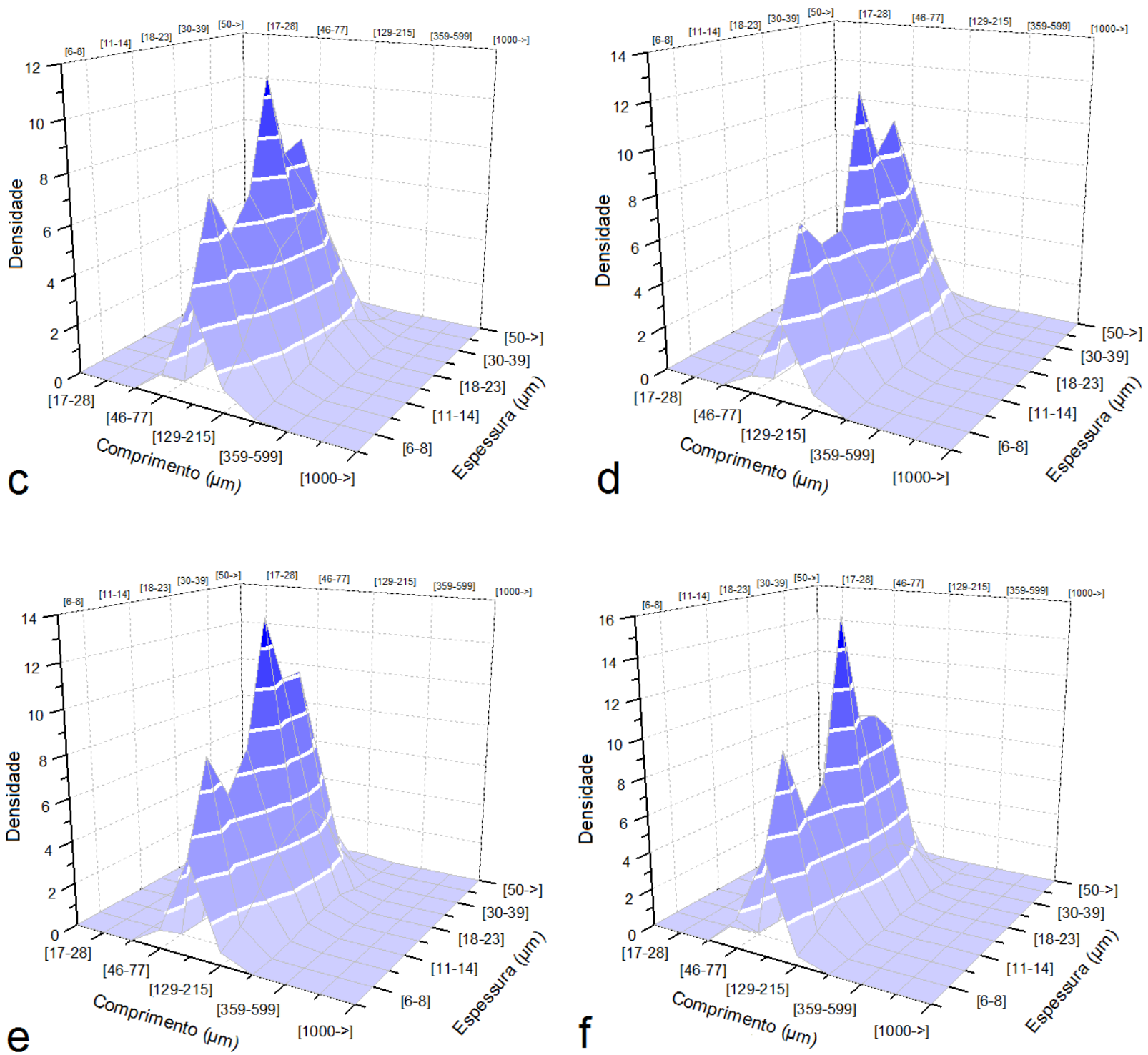

Figura 56 - Mapas de densidade das polpas iniciais [Fração 1 - a; Fração 4 - b] e residuais [não hidrolisadas] das reações realizadas a partir da Fração 1, após 180 min [c] e 360 min [e], e a partir da Fração 4, após 180 min [d] e 360 min [e].

No que diz respeito às diferenças nos mapas de densidade promovidas pelo fracionamento [Figura 56-a,b], observa-se que as regiões com maior densidade da Fração 4 estão localizadas em intervalos de menores comprimentos e espessuras, sendo que enquanto a maior densidade das fibras se localiza na região de comprimentos entre [359-599] um e na região de espessuras entre [18-50] um no caso da Fração 1, ocorre o deslocamento das fibras para as regiões de comprimentos entre [46-215] $\mu \mathrm{m}$ e para regiões de espessuras entre [11-23] um no caso da Fração 4. Comparando os mapas a, c e e [Figura 56], em que o mapa a corresponde à polpa inicial da reação executada a 
partir da Fração 1 ( $\mathrm{t}=$ 0), e os mapas c e e correspondem à polpa residual [não hidrolisada] depois de, respectivamente, 180 e 360 min de reação, pode-se observar que após este intervalo de tempo as fibras residuais se mostraram menores, fato que é indicado pelo deslocamento dos mapas na direção das fibras mais curtas (entre 46 e $215 \mu \mathrm{m}$ ) e menos espessas [entre 11 e 23 um após 360 min de reação], e pelo aumento da densidade das fibras nesta região (eixo z], partindo de aproximadamente 10 ( $\mathrm{t}=180$ min] para aproximadamente 12 ( $\mathrm{t}=360 \mathrm{~min}$ ), ou seja, houve um aumento na densidade das fibras de menores comprimentos e espessuras. 0 mesmo indicador foi observado [embora mais sutilmente do que quando a Fração 1 foi usada como polpa de partida], quando a Fração 4 foi avaliada [Figura 56-b,d,f]. A partir dos mapas correspondentes pode ser inferido que a população das fibras de comprimento entre [46-77] e [129-215] $\mu m$ aumentou, e a densidade das fibras concentradas nas regiões de [30-39] $\mu m$ de espessura diminuiu, indicando uma diminuição no comprimento e também na espessura média das fibras. Um comportamento análogo é observado quando as Frações 2 e 3 [Figuras não mostradas] são usadas como polpa de partida, ou seja, maiores períodos de exposição à solução ácida levaram a fibras com dimensões localizadas em regiões de menores comprimentos e espessuras [entre 46 e $215 \mu \mathrm{m}$ e entre 11 e $23 \mu \mathrm{m}$ ), e esta variação foi mais evidente quando a Fração 2 foi usada comparativamente à Fração 3 , uma vez que o mapa de densidade das fibras da Fração 2 indica maiores densidades em regiões correspondentes às fibras mais longas e mais espessas, em regiões de comprimentos entre 215 e $599 \mu \mathrm{m}$ e de espessuras entre 15 e $50 \mu \mathrm{m}$.

\subsubsection{Caracterização dos produtos gerados nas reações de hidrólise}

Para as reações realizadas partindo de amostras com variação de tamanhos médios de fibras, apenas as curvas que mostram a evolução de glicose e xilose em função do tempo serão apresentadas, pois são aquelas em que a influência do tamanho médio 
das fibras frente à hidrólise ácida foi mais intensa. Arabinose, ácido fórmico, furfural e HMF foram detectados para todas as amostras analisadas por CLAE, com concentrações máximas de 0,18 $\mathrm{gL}^{-1}$ [120 min], 1,3 $\mathrm{gL}^{-1}$ [360 min], 0,42 $\mathrm{gL}^{-1}$ [150 min] e 0,04 $\mathrm{gL}^{-1}$ [360 min], respectivamente, sendo que todas foram provenientes da reação em que o material de partida correspondeu a Fração 1, destacando a facilidade da hidrólise deste material, provavelmente devido à menor quantidade de regiões cristalinas presentes nele [Tabela 7], comparativamente às demais frações.

Na Figura 57 estão contidas as curvas referentes às concentrações de glicose e xilose provenientes destas reações, e a Tabela 8 sumariza as concentrações máximas destas substâncias detectadas para cada uma delas. 

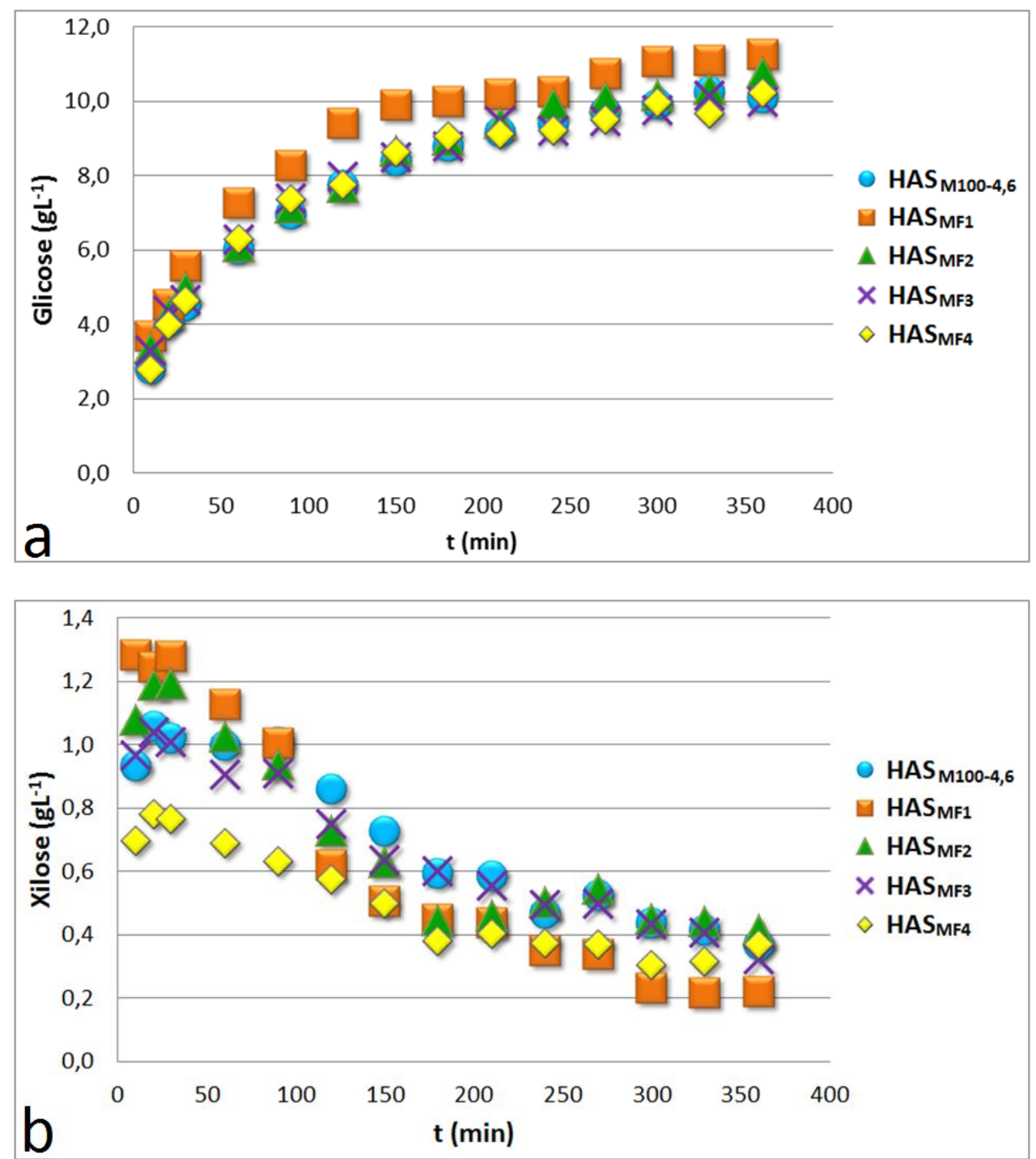

Figura 57 - Concentração de glicose [a] e xilose [b] em função do tempo de reação, com a variação do tamanho médio das fibras $\left[4,6 \mathrm{molL}^{-1} \mathrm{H}_{2} \mathrm{SO}_{4}, 100^{\circ} \mathrm{C}\right]$. 
Tabela 8 - Valores de índice de cristalinidade e comprimento e espessura médios das diferentes frações de polpas de partida usadas, e o respectivo valor máximo de concentração de xilose e glicose obtidos a partir delas.

\begin{tabular}{|c|c|c|c|c|c|}
\hline Reação & $I_{c}[\%]$ & $\begin{array}{c}\text { Comprimento } \\
\text { médio }[\mu \mathrm{m}]\end{array}$ & $\begin{array}{l}\text { Espessura } \\
\text { média }(\mu \mathrm{m})\end{array}$ & $\begin{array}{c}\text { [Glicose }]_{\max } \\
\left.\text { [gL }^{-1}\right]\end{array}$ & $\begin{array}{c}\text { [Xilose }]_{\max } \\
{\left[\mathrm{gL}^{-1}\right]}\end{array}$ \\
\hline $\mathrm{HAS}_{\mathrm{M} 1004,6}$ & 69 & 238 & 21 & $\begin{array}{c}10,2 \\
{[t=330 \mathrm{~min}]}\end{array}$ & $\begin{array}{c}1,1 \\
{[t=20 \mathrm{~min}]}\end{array}$ \\
\hline HAS $_{\text {мF1 }}$ & 65 & 383 & 21 & $\begin{array}{c}11,2 \\
{[t=360 \mathrm{~min}]}\end{array}$ & $\begin{array}{c}1,3 \\
{[t=10 \mathrm{~min}]}\end{array}$ \\
\hline HAS $_{\text {мF2 }}$ & 72 & 313 & 20 & $\begin{array}{c}10,8 \\
{[t=360 \mathrm{~min}]}\end{array}$ & $\begin{array}{c}1,2 \\
{[t=30 \mathrm{~min}]}\end{array}$ \\
\hline HAS $_{\text {мF3 }}$ & 73 & 249 & 20 & $\begin{array}{c}10,1 \\
{[t=330 \mathrm{~min}]}\end{array}$ & $\begin{array}{c}1,0 \\
{[t=20 \mathrm{~min}]}\end{array}$ \\
\hline HAS $_{\mathrm{MF}}$ & 75 & 130 & 19 & $\begin{array}{c}10,2 \\
{[t=360 \mathrm{~min}]}\end{array}$ & $\begin{array}{c}0,8 \\
{[t=20 \mathrm{~min}]}\end{array}$ \\
\hline
\end{tabular}

Com relação à produção de glicose em função do tempo de reação (Figura 57-a], a Fração 1 foi a única que possibilitou uma maior produção de glicose, com valores até $22 \%$ maiores em $\mathrm{t}=120$ min, quando comparados àqueles obtidos para a polpa não fracionada. Conforme mostrado na Tabela 8, a Fração 1 possui $I_{c}=65 \%$, enquanto que para a Fração 4 este valor é de 75\%. Esta diferença pode ser decisiva quando a reação é conduzida em meio heterogêneo, como é o caso da reação de hidrólise de celulose. A relação entre o tamanho médio das fibras e a concentração de xilose é claramente observada (Figura 57-b): quando a Fração 1 foi utilizada como material de partida, a concentração de xilose atingiu valores até 82\% maiores do que aqueles obtidos com a Fração 4, para t $=10$ min. 


\section{REAC̣ÕES COM VARIAC̣ÃO DE TEMPERATURA PARA O CÁLCULO DA ENERGIA DE ATIVAC̣̃̃O}

Nesta seção, a reação usando concentração de 4,6 molL-1 de ácido sulfúrico foi escolhida para que, a partir dela, fosse realizada uma série de reações com temperaturas variando entre 60 e $100^{\circ} \mathrm{C}$, com a finalidade de calcular o valor da energia de ativação [Ea da reação. A polpa de partida foi a mercerizada, sem fracionamento.

A Figura 58 mostra a concentração de glicose em função do tempo, para as reações realizadas a diferentes temperaturas.

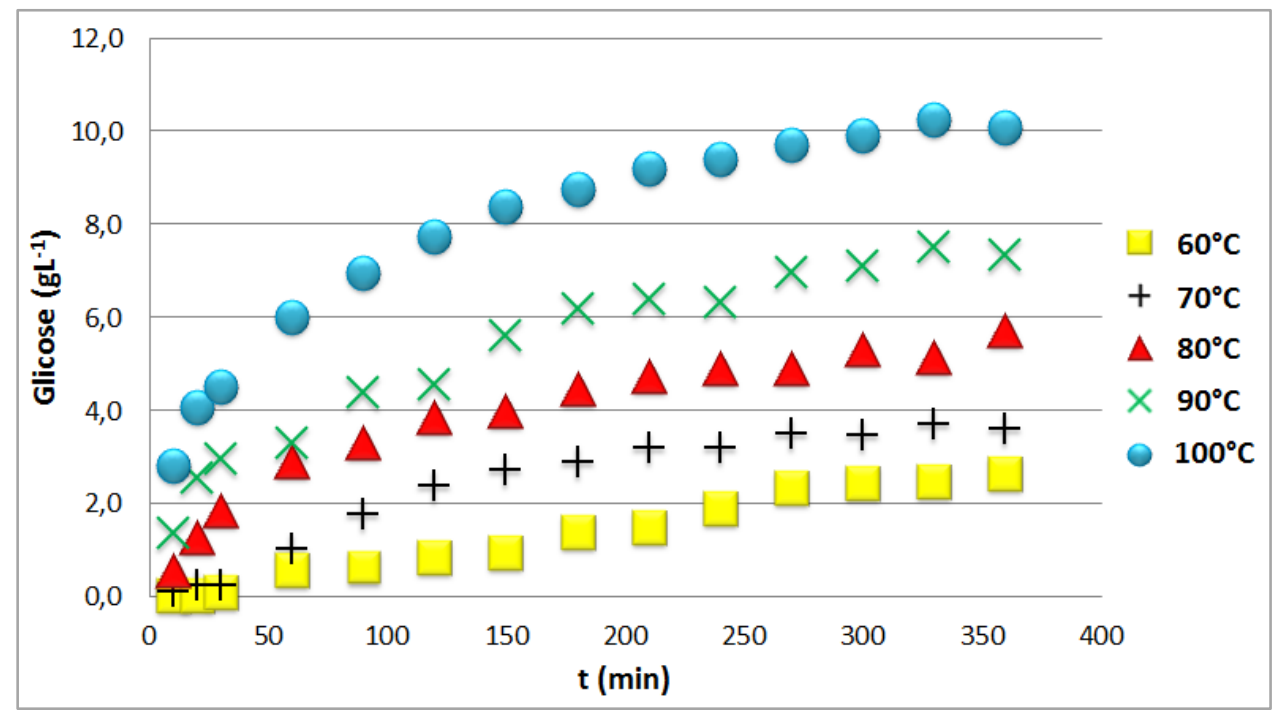

Figura 58 - Concentração de glicose no licor em função do tempo de hidrólise: 60-100² 4,6 molL $^{-1}$ $\mathrm{H}_{2} \mathrm{SO}_{4}$.

Os resultados mostram claramente a influência da temperatura na produção de glicose a partir da polpa de sisal mercerizada. Em posse destes gráficos, é possível calcular o valor da constante cinética de formação de glicose a partir da celulose [ $k_{1}$, Equação 1] para as reações nas diferentes temperaturas. Para isso, será usado o modelo proposto por Saeman [Equação 6]. Os valores de $k_{1}$ serão usados, subsequentemente, para o cálculo do valor da $E_{a}$ da hidrólise ácida de celulose de sisal nestas condições [Equação 22]. 
Os gráficos a seguir mostram o ajuste não linear do modelo de Saeman para as curvas de concentração de glicose em função da temperatura. Os valores de $k_{1}$, $k_{2}$ e $R^{2}$, referentes a estes gráficos, estão inseridos na Tabela 9.

Para que o modelo fosse aplicado às curvas experimentais de concentração de glicose, o software OriginPro 8 SRO versão 8.0724 [B724] foi utilizado. Através da ferramenta de ajuste não linear do software, os dados puderam ser ajustados ao modelo.
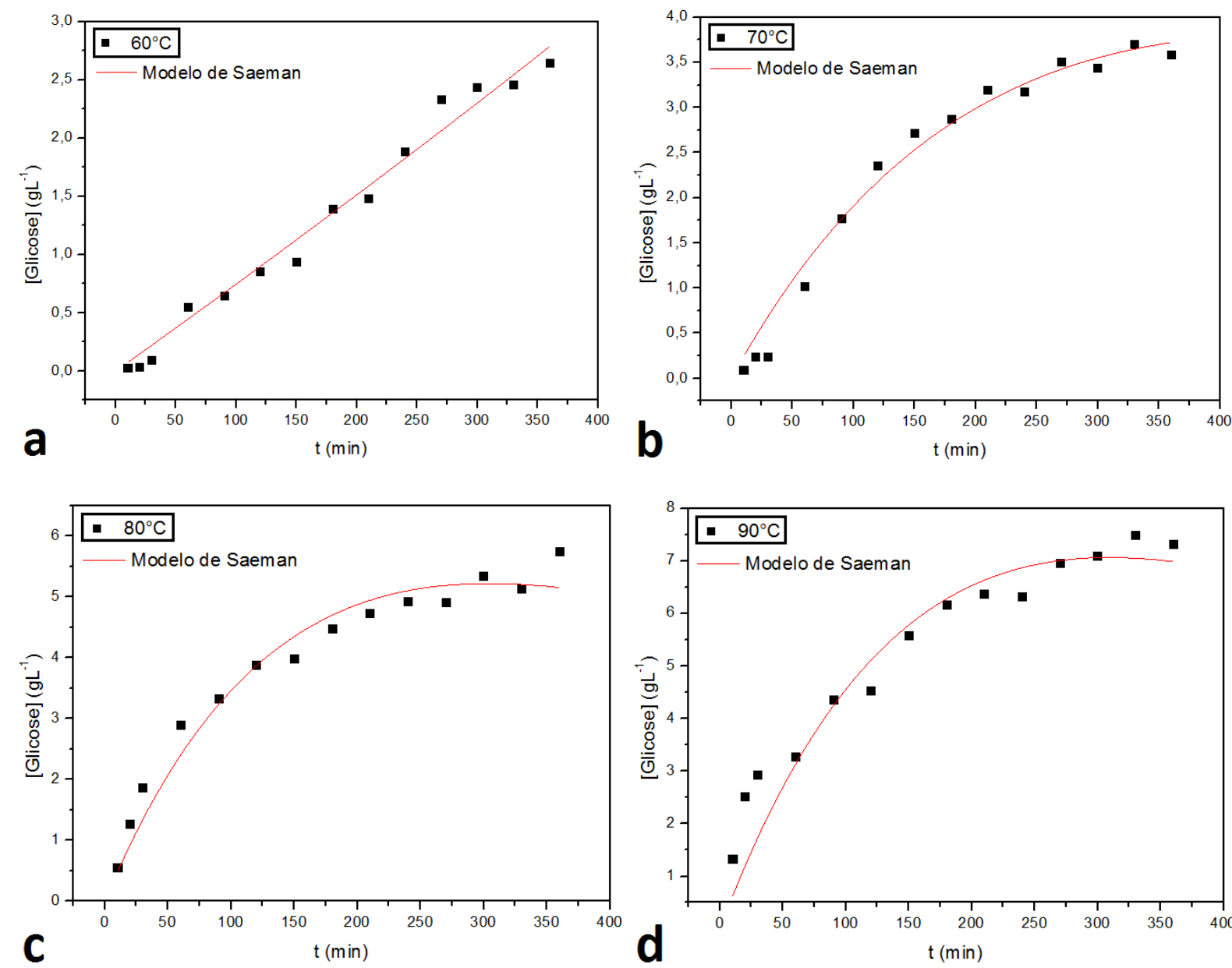


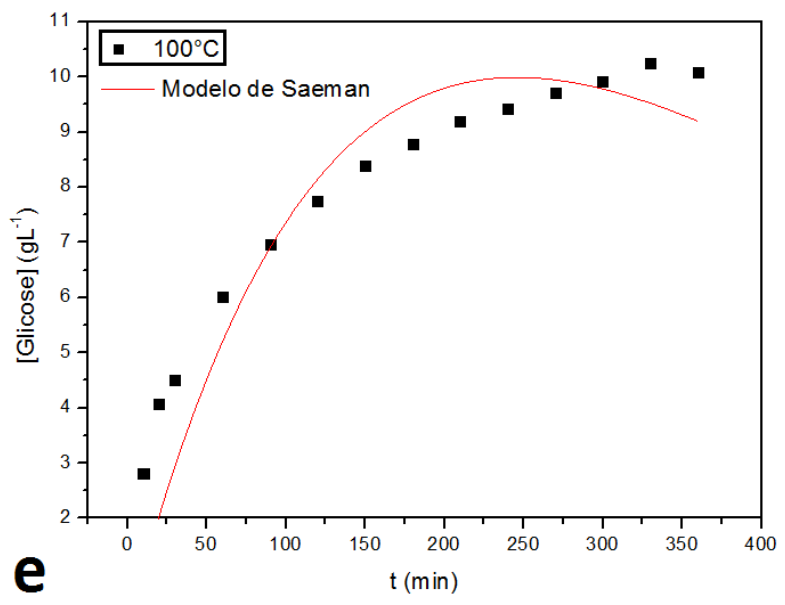

Figura 59 - Ajuste não linear do modelo de Saeman para hidrólise ácida de celulose $\left[4,6\right.$ molL ${ }^{-1} \mathrm{H}_{2} \mathrm{SO}_{4}$, $60-100^{\circ} \mathrm{C}$.

Tabela 9 - Constantes de hidrólise de celulose $\left[k_{1}\right]$, decomposição de glicose $\left[k_{2}\right]$ e valor de $R^{2}$

\begin{tabular}{cccccc}
\hline & $\mathbf{6 0 ^ { \circ } \mathbf { C }}$ & $\mathbf{7 0}^{\circ} \mathbf{C}$ & $\mathbf{8 0}^{\circ} \mathbf{C}$ & $\mathbf{9 0}^{\circ} \mathbf{C}$ & $\mathbf{1 0 0}^{\circ} \mathbf{C}$ \\
\hline $\mathbf{k}_{\mathbf{1}} \times \mathbf{1 \mathbf { 0 } ^ { 3 }}$ & 0,2 & 0,8 & 1,6 & 2,0 & 3,6 \\
$\mathbf{k}_{\mathbf{2}} \times \mathbf{1 0}$ & 0 & 4,4 & 5,9 & 4,8 & 4,6 \\
$\mathbf{R}^{\mathbf{2}}$ & 0,980 & 0,979 & 0,956 & 0,899 & 0,813 \\
\hline
\end{tabular}

Os valores de $\mathrm{R}^{2}$ mostrados na Tabela $\mathbf{9}$ indicam que os dados experimentais se ajustam razoavelmente bem ao modelo de Saeman, com exceção da reação conduzida a $100^{\circ} \mathrm{C}\left[\mathrm{HAS}_{\mathrm{M}_{1004,6}}\right]$, para a qual o valor de $\mathrm{R}^{2}$ é 0,813 . Os valores de $\mathrm{k}_{1}$ e $\mathrm{k}_{2}$ mostram que, com exceção da reação realizada a $60^{\circ} \mathrm{C}$, para todas as temperaturas consideradas, a constante de velocidade da reação de decomposição é maior que a de formação de glicose.

A partir da lei geral de Arrhenius [Equação 15], em que a velocidade da reação é relacionada à temperatura, a energia de ativação para hidrólise ácida de celulose de sisal pode ser calculada para as condições do presente trabalho.

$$
k_{1}=w e^{\frac{-E_{a}}{R T}}
$$


Sendo w um fator pré-exponencial de mesma unidade que $k_{1}$; $E_{a}$ a energia de ativação; $R$ a constante dos gases $\left[8,3143 \times 10^{-3} \mathrm{~kJ} \mathrm{~mol}^{-1} \cdot \mathrm{K}^{-1}\right]$ e T a temperatura absoluta [em Kelvin].

O logaritmo da Equação 15 é:

$$
\ln k_{1}=\frac{-E_{a}}{R T}+\ln w
$$

Assim, o valor da energia de ativação é calculado através da equação da reta gerada em um gráfico de $\ln k_{1}$ em função de 1/T.

Assim, foi gerado um gráfico [Figura 60] do logaritmo de $k_{1}$ em função do inverso da temperatura absoluta para obter a energia de ativação.

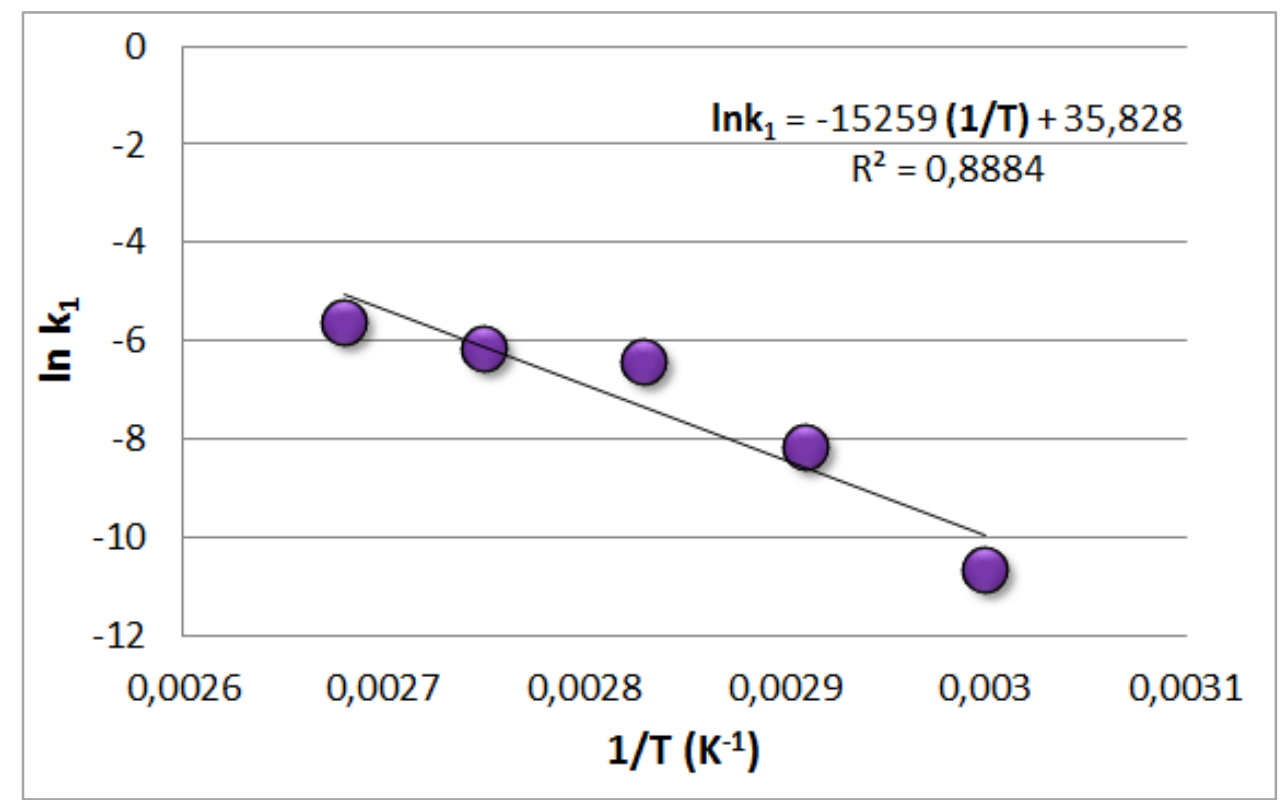

Figura 60 - Gráfico de Arrehnius para hidrólise ácida de celulose de sisal $[60$ - 100 e 4,6 molL-1 de $\left.\mathrm{H}_{2} \mathrm{SO}_{4}\right]$.

Portanto, a partir da Figura 60, tem-se que $\mathrm{E}_{\mathrm{a}}=126,9 \mathrm{kJmol}^{1}$.

Najafpour e colaboradores [NAJAFPOUR et al., 2007) encontraram para hidrólise ácida de polpas de palmeiras previamente tratadas com solução alcalina, energias de ativação entre aproximadamente 64 e $84 \mathrm{kJmol}^{-1}$, para concentrações de $\mathrm{HCl}$ variando entre 10 e 30\%, ou seja, valores mais baixos que os encontrados no presente 
trabalho. Diferenças entre cristalinidade e massa molar média, por exemplo, considerando o sisal e polpa de madeira, podem levar a estas diferenças observadas. Por outro lado, as hidrólises de celulose de linter $\left[65 \% \mathrm{H}_{2} \mathrm{SO}_{4}\right]$ e de polpa de madeira Eucalipto $\left[67,5 \% \mathrm{H}_{2} \mathrm{SO}_{4}\right]$ têm como energia de ativação 125,5 $\mathrm{kJmol}^{-1}$ e 118,5 kJmol ${ }^{-1}$ [GARVES, 1996], valores que se aproximam mais daquele encontrado no presente trabalho.

A energia de ativação referente à decomposição da glicose não foi calculada no presente trabalho, mas vários estudos foram feitos a partir de polpas oriundas de diferentes fontes, em condições que permitiram o cálculo deste parâmetro para esta etapa. Em todos os estudos foi encontrado que a energia de ativação da decomposição da glicose é menor que aquela da hidrólise ácida das celuloses [QUINTERO-RAMIREZ, 2008].

Na sequência, o ácido sulfúrico usado até o momento foi substituído pelo ácido oxálico como catalisador na reação de hidrólise ácida de polpa de sisal. 


\subsubsection{REAÇÕES DE HIDRÓLISE ÁCIDA, COM ÁCIDO OXÁLICO COMO CATALISADOR}

Conforme mencionado anteriormente, uma primeira reação exploratória de hidrólise ácida, usando ácido oxálico como catalisador, foi realizada com $[\mathrm{COOH}]_{2} 0,9$ molL $^{-1}$, para polpa de celulose não mercerizada. Nesta concentração, o ácido oxálico é totalmente solúvel em água, a temperatura ambiente, e o sistema de retirada de alíquotas é facilitado. Na sequência, reações com $[\mathrm{COOH}]_{2} 4,6 \mathrm{molL}^{-1}$ e $100^{\circ} \mathrm{C}$ foram feitas com celulose previamente mercerizada. Um dos objetivos do uso deste ácido consistiu em comparar sua atividade catalítica com a do ácido sulfúrico, uma vez que o ácido oxálico pode ser produzido a partir de fontes renováveis, e as primeiras reações realizadas foram para $t=1,2,3,4,5$ e 6h. Como foi observado que a produção de glicose estava consideravelmente abaixo da atingida com o uso do ácido sulfúrico, a sequência das reações foi realizada considerando tempos maiores que 6h, ou seja, 8, 10, 12, 14 e 16h. Uma série de reações com variação de temperatura foi realizada, complementar à esta. A concentração de ácido oxálico foi mantida em 4,6 $\mathrm{molL}^{-1}$ e as temperaturas empregadas foram de 80, 85, 90 e 95, com a finalidade de calcular o valor da energia de ativação para a reação de hidrólise ácida de polpa de sisal, usando ácido oxálico como catalisador.

A Tabela 10 exprime a representação por códigos das reações de hidrólise nas condições em que foram realizadas, sendo que: "HAO" é a abreviação de "hidrólise com ácido oxálico", ST representa a polpa sem tratamento prévio e M representa a polpa previamente mercerizada, seguido da temperatura e da respectiva concentração de ácido. 
Tabela 10 - Códigos usados para denominar as reações estudadas, de acordo com as condições de concentração de ácido, temperatura e tempo de reação.

\begin{tabular}{|c|c|c|c|c|}
\hline Código & $\begin{array}{c}\text { Polpa de } \\
\text { partida }\end{array}$ & $\begin{array}{c}\text { Concentração de } \\
\text { ácido } \\
\text { [molL-1] }\end{array}$ & $\begin{array}{c}\text { Temperatura } \\
\left.\text { [ }{ }^{\circ} \mathrm{C}\right]\end{array}$ & $\begin{array}{l}\text { Tempo de } \\
\text { reação (h] }\end{array}$ \\
\hline$H A O_{\text {st100-0,9 }}$ & $\begin{array}{c}\text { Sem } \\
\text { tratamento }\end{array}$ & 0,9 & 100 & 10min-6h* \\
\hline $\mathrm{HAO}_{\mathrm{M100-4,6}}$ & Mercerizada & 4,6 & 100 & $1-16 h$ \\
\hline $\mathrm{HAO}_{\mathrm{M95-4,6}}$ & Mercerizada & 4,6 & 95 & $1-16 h$ \\
\hline $\mathrm{HAO}_{\text {м90-4,6}}$ & Mercerizada & 4,6 & 90 & $1-16 h$ \\
\hline $\mathrm{HAO}_{\mathrm{M85-4,6}}$ & Mercerizada & 4,6 & 85 & $1-16 h$ \\
\hline $\mathrm{HAO}_{\mathrm{M80-4,6}}$ & Mercerizada & 4,6 & 80 & $1-16 h$ \\
\hline
\end{tabular}

${ }^{\star}$ Foi usado tempo de retirada de alíquotas similar ao descrito para o ácido sulfúrico.

Analogamente à hidrólise com ácido sulfúrico, as modificações decorrentes da hidrólise ácida com ácido oxálico foram analisadas tanto no licor contendo o material hidrolisado, quanto nas fibras residuais que não foram totalmente hidrolisadas, sendo que estes foram separados por filtração simples. No caso das reações com concentrações de $[\mathrm{COOH}]_{2}$ iguais a 4,6 $\mathrm{molL}^{-1}$, a polpa residual retida no filtro foi lavada exaustivamente com água destilada em ebulição, para eliminar todo $[\mathrm{COOH}]_{2}$ que recristalizava sobre ela na temperatura ambiente.

\subsubsection{Caracterização da polpa residual}

As polpas residuais de cada reação foram caracterizadas da mesma maneira que a polpa de partida.

Na Figura 61 estão mostrados os valores de massa molar média das polpas residuais referentes às reações com ácido oxálico, obtidos através de medidas de viscosimetria. 

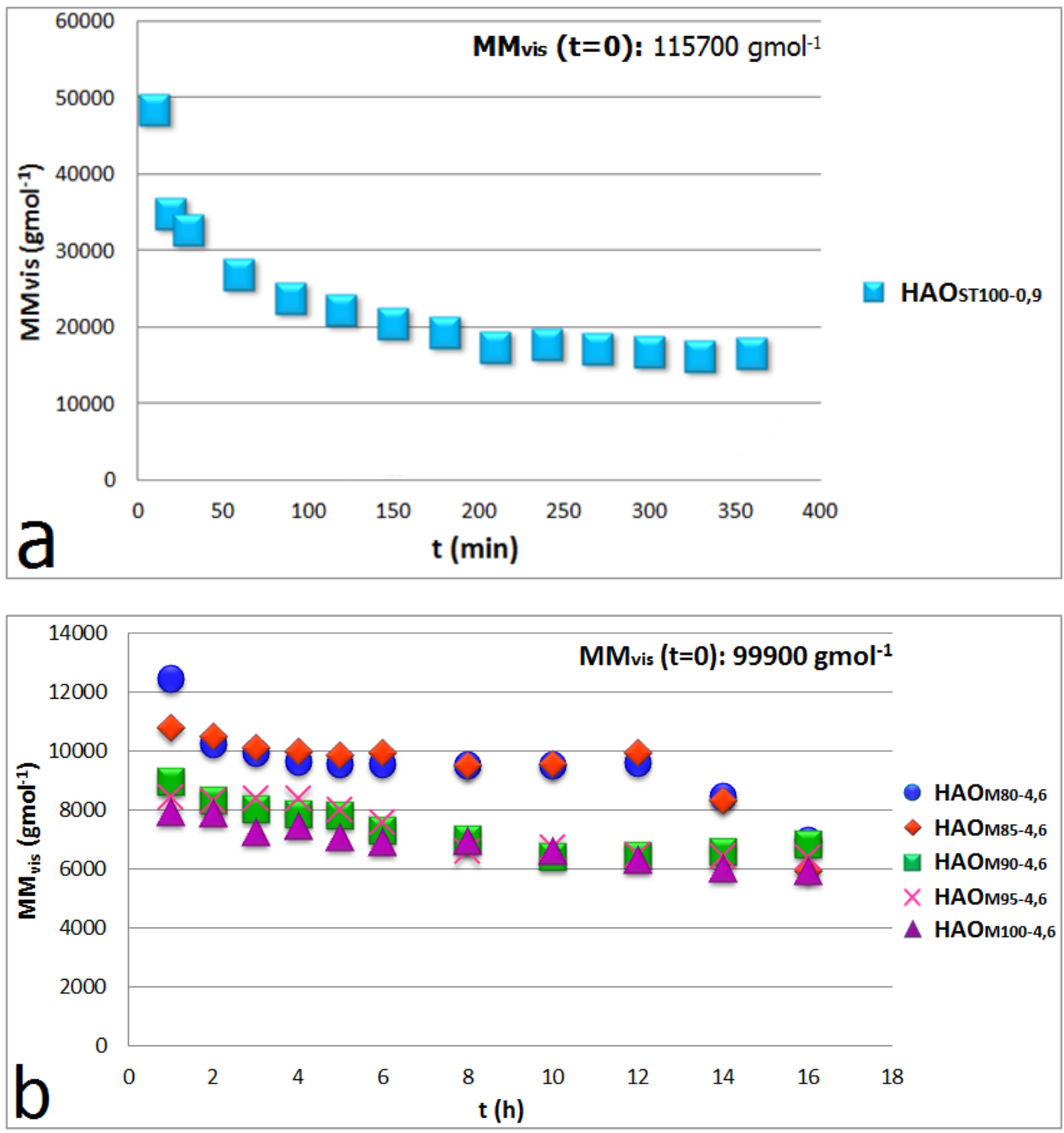

Figura 61 - Valores de massa molar média viscosimétrica obtidos a partir da análise das polpas residuais das reações de hidrólise com celulose [a] sem tratamento e [b] mercerizada (temperaturas entre 80 e $\left.100^{\circ} \mathrm{C}, 4,6 \mathrm{molL}^{-1}[\mathrm{COOH}]_{2}\right]$.

Nota-se, através da Figura 61-a, que há uma diminuição no valor da massa molar

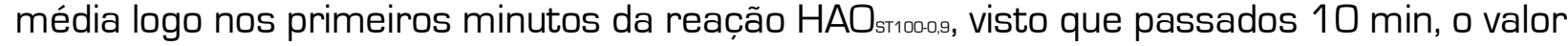
inicial [em torno de $115700 \mathrm{gmol}^{-1}$ ] diminuiu para aproximadamente $50000 \mathrm{gmol}^{-1}$, o que representa uma redução de aproximadamente 55\%. Ao longo do tempo pode-se observar uma queda exponencial até cerca de 210 min, seguida de uma relativa estabilidade no valor de $\mathrm{MM}_{\text {wis }}$ em torno de $16000 \mathrm{gmol}^{-1}$.

Na Figura 61-b, que corresponde às celuloses residuais das reações realizadas com ácido oxálico 4,6 molL-1, a partir de polpa mercerizada, nota-se que a diminuição drástica no valor de $\mathrm{MM}_{\text {vis }}$ para todas as temperaturas avaliadas é uma evidência de que o 
ácido oxálico aplicado na concentração adequada pode ser usado como catalisador para a hidrólise de polpa de celulose proveniente do sisal, usando tempo reacional maior. valor inicial de $\mathrm{MM}_{\text {vis }}\left[99900 \mathrm{gmol}^{-1}\right.$ ] foi reduzido para aproximadamente $6000 \mathrm{gmol}^{-1}$ após 16h de reação, o que representa uma redução de 94\% no valor de massa molar média.

A análise de difração de raios $X$ forneceu os valores de índice de cristalinidade das polpas residuais das reações feitas. A Figura 62-a mostra a variação de $\mathrm{I}_{\mathrm{c}}$ para cinco

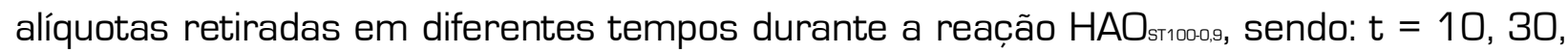
120, 240 e 360 min. A Figura 62-b mostra esta mesma evolução, desta vez, para as celuloses residuais das reações com ácido oxálico 4,6 molL-1, que partiram de polpa de sisal mercerizada, a diferentes tempos e temperaturas. 

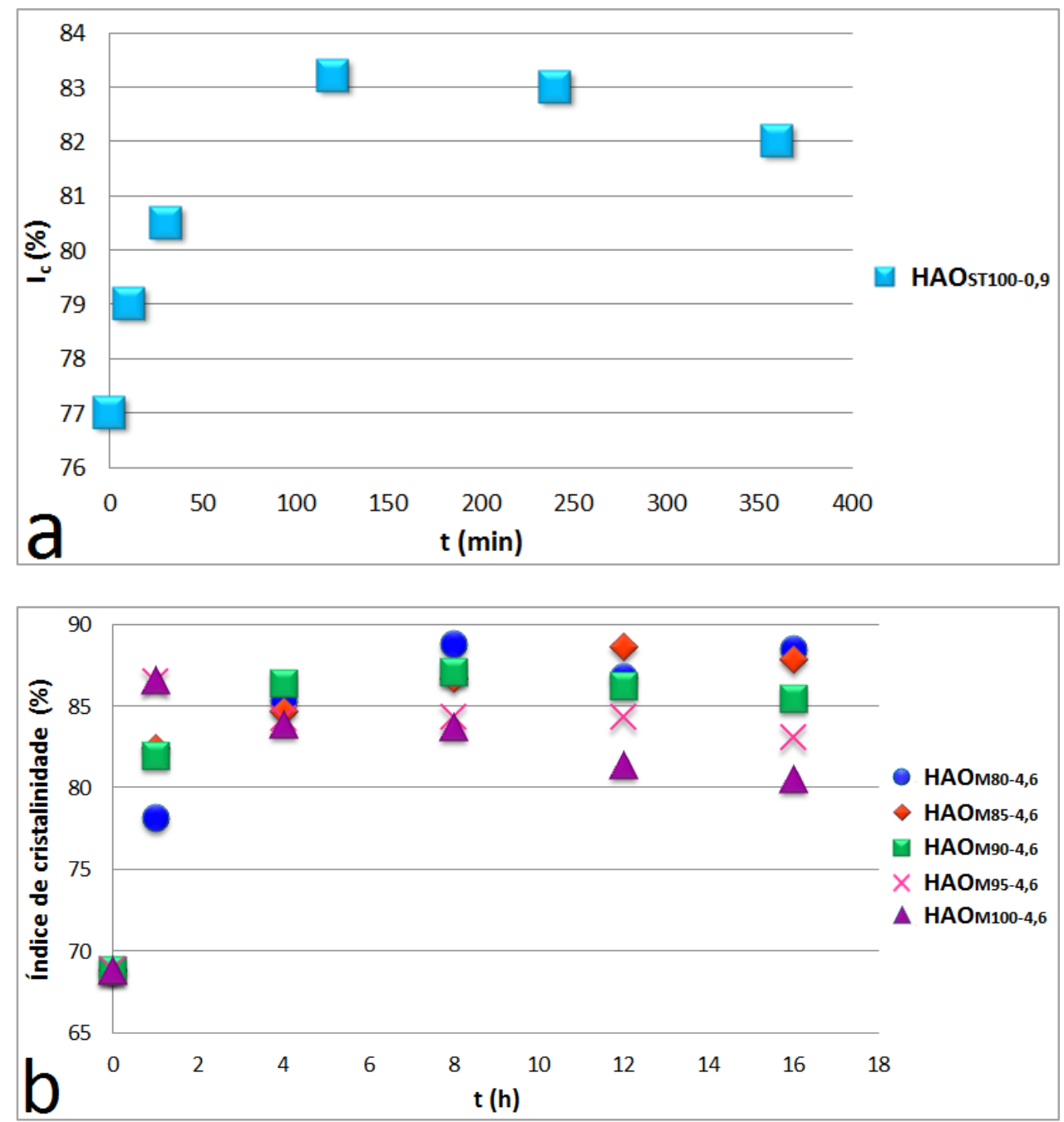

Figura 62 - Índice de cristalinidade das celuloses residuais das reações [a] HAOsт100,9 e [b] com ácido oxálico 4,6 molL'-1, em função do tempo.

Através da Figura 62-a, pode-se observar que houve primeiramente um aumento no valor de $I_{c}$, indicando que nos primeiros instantes da hidrólise a fração não cristalina da polpa celulósica foi sendo hidrolisada, enquanto a fração cristalina permaneceu inalterada. Nota-se que a partir de 120 min de reação, a fração cristalina da celulose começou a também ser hidrolisada, ocorrendo uma diminuição no valor de $I_{c}$, mesmo que pouco acentuada. 0 mesmo fenômeno ocorre, em maior extensão, para as celuloses remanescentes das reações com ácido 4,6 $\mathrm{molL}^{-1}$ [Figura 62-b], através da qual nota-se que maiores concentrações de ácido oxálico permitiram a hidrólise, em maior extensão, das cadeias de celulose presentes nas regiões cristalinas, levando a uma diminuição gradativa do índice de cristalinidade com o aumento da concentração de ácido e do 
tempo de exposição, após o aumento inicial que corresponde à hidrólise das regiões não cristalinas das fibras.

A Figura 63 mostra a variação dos domínios cristalinos das celuloses residuais no decorrer dos experimentos com 0,9 $\mathrm{molL}^{-1}$ de ácido oxálico $\left(100^{\circ} \mathrm{C}\right.$, a partir de polpa sem tratamento] e com 4,6 $\mathrm{molL}^{-1}$ de ácido [80-100․ a partir de polpa mercerizada].
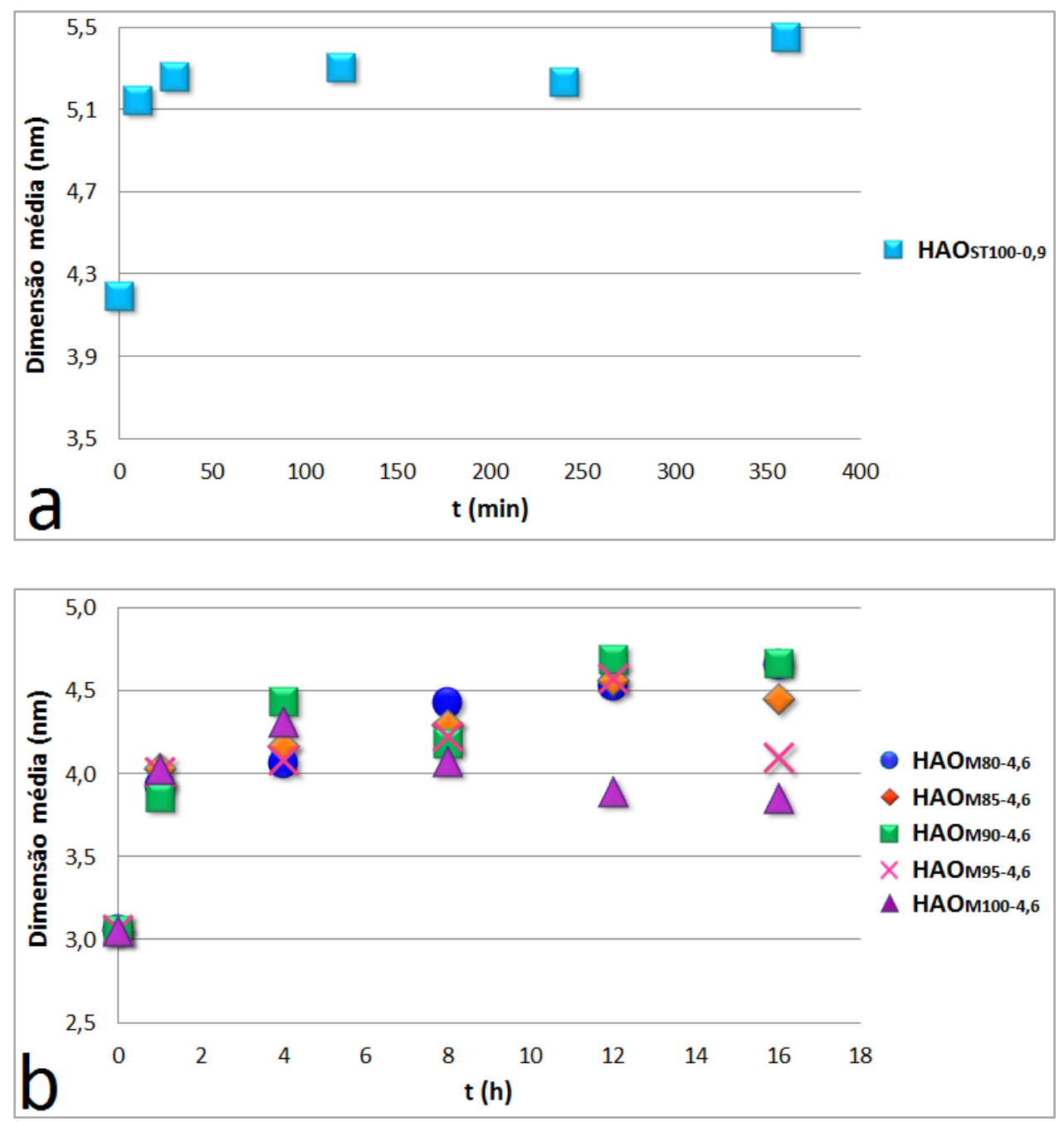

Figura 63 - Dimensão do plano 002 das polpas residuais em função do tempo de reação [a] partindo de polpa sem tratamento e $[\mathrm{COOH}]_{2} 0,9 \mathrm{moll}^{-1}, 100^{\circ} \mathrm{C}$ e (b) partindo de polpa mercerizada e $[\mathrm{COOH}]_{2}$ $4,6 \mathrm{moll}^{-1}, 80-100^{\circ} \mathrm{C}$.

Nota-se, a partir da Figura 63-a, que não houve grande variação nas dimensões dos domínios cristalinos das cadeias presentes nas alíquotas de celulose não hidrolisada retiradas da reação envolvendo 0,9 $\mathrm{molL}^{-1}$ de ácido oxálico e polpa sem tratamento. Após 
10 min de reação, houve um aumento considerável deste valor [cerca de 20\%], que se manteve aproximadamente constante até 240 min, seguido de um aumento em t $=360$ min. Observa-se que quando a concentração do ácido oxálico aumenta para 4,6 $\mathrm{molL}^{-1}, \mathrm{~T}^{\mathrm{N}}=$ $100^{\circ} \mathrm{C}$, e a polpa de partida é a mercerizada, o aumento inicial das dimensões dos cristalitos também ocorre, seguido de diminuição a partir de 8h de reação [Figura 63-b], fenômeno que é acentuado a partir de 12h de reação. Para temperaturas menores, se observa um comportamento diferenciado, com as dimensões médias aumentando até 12h de reação, o que possivelmente indica a reorganização de segmentos ou junções de domínios cristalinos.

A Figura 64 mostra as micrografias das polpas residuais da reação $H A O_{\text {sт100-0,9 }}$ após 30 min [Figura 64-a] e 240 min [Figura 64-b] de reação.
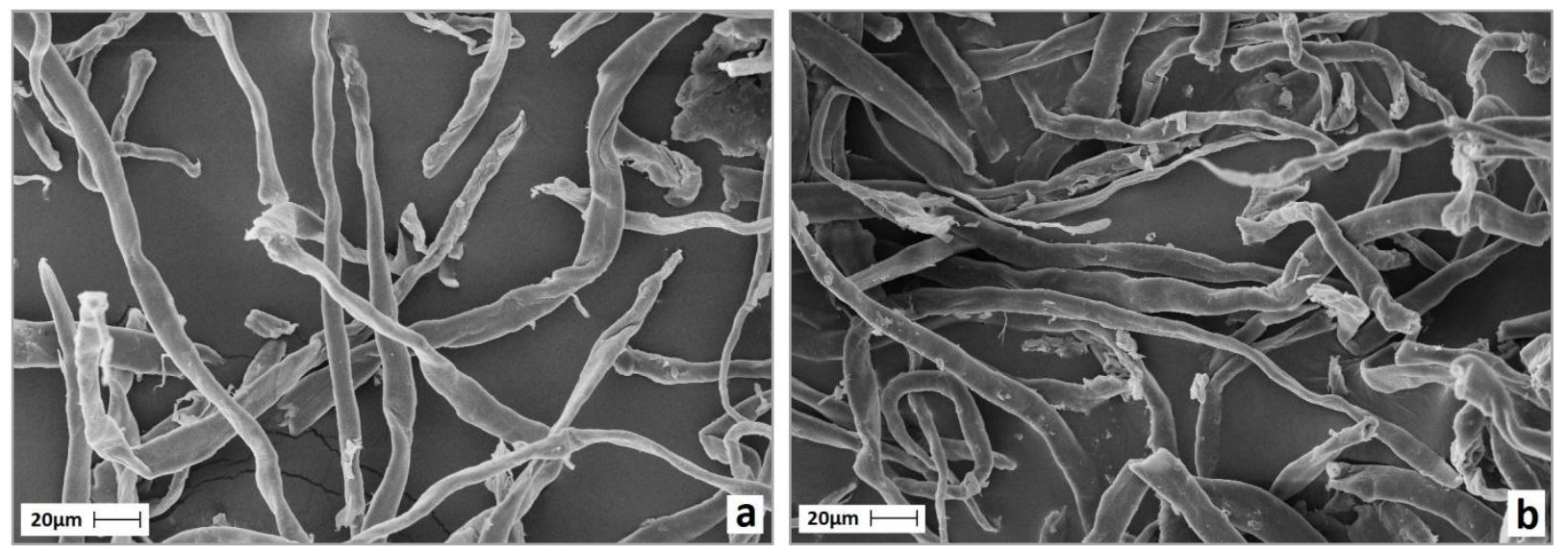

Figura 64 - Micrografias das polpas residuais da reação HAOsтroo.,a após 30 min [a] e 240 min (b).

Nesta concentração, o ácido oxálico, por ter grau de ionização bastante inferior ao ácido sulfúrico, não é capaz de hidrolisar as cadeias de celulose na mesma extensão com que este fenômeno ocorre na presença do ácido inorgânico (Figura 40], o que fica evidente quando as respectivas imagens são comparadas após 240 min de reação [Figura 64-b], evidenciando a maior eficiência de hidrólise quando o ácido sulfúrico é empregado nestas condições. 
A Figura 65 ilustra a micrografia das polpas residuais das reações realizadas com polpa de sisal mercerizada $\left(80-100^{\circ} \mathrm{C}\right]$ e $[\mathrm{COOH}]_{2} 4,6 \mathrm{molL}^{-1}$, após 6 e $16 \mathrm{~h}$.
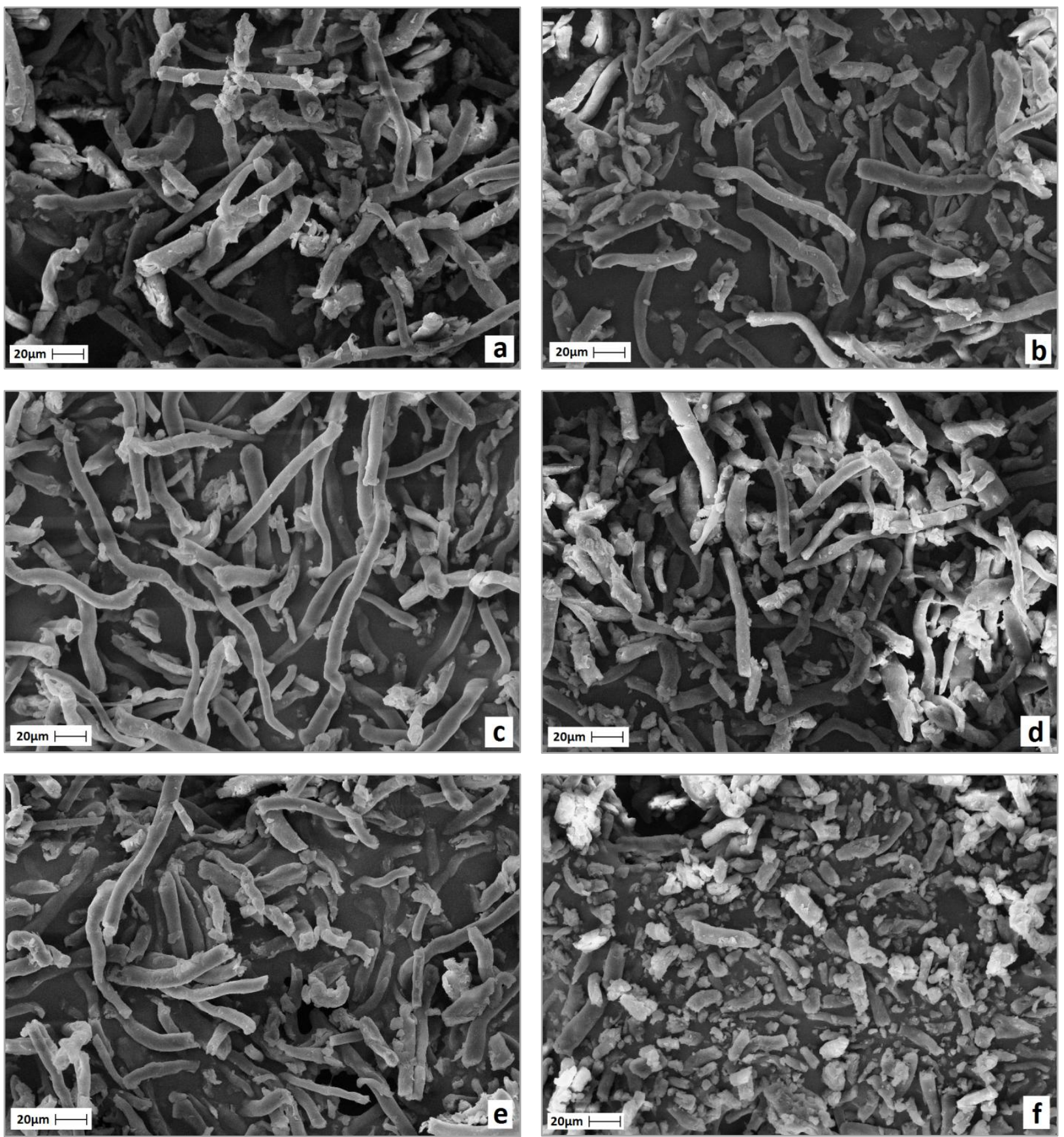

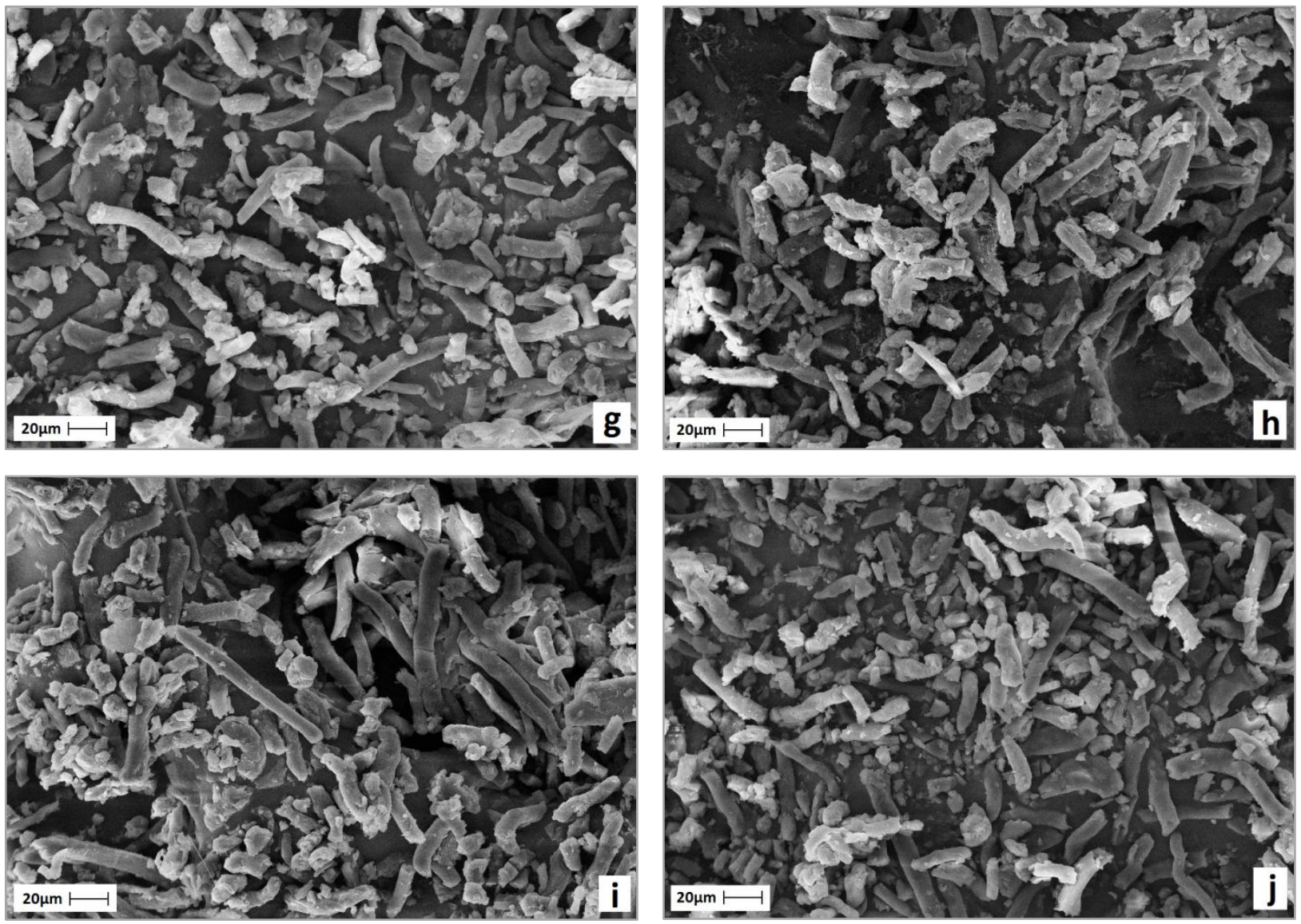

Figura 65 - Micrografia das polpas residuais das reações $\mathrm{HAO}_{\text {м804,6 }}$ [a,b], $\mathrm{HAO}_{\text {мв54,6 }}$ [c,d], $\mathrm{HAO}_{\text {м904, }}$ [e,f],

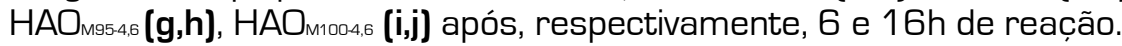

As imagens indicam que o ácido oxálico é mais eficiente como catalisador na reação de hidrólise ácida de celulose quando aplicado em maiores temperaturas, o que fica claro ao se comparar as imagens i e a [Figura 65]: o sistema que foi mantido a $100^{\circ} \mathrm{C}$ possibilitou uma maior extensão na fragmentação das fibras, quando comparado com as fibras provenientes do sistema a $80^{\circ} \mathrm{C}$.

A Figura 66 mostra os mapas de densidade referentes às medidas de tamanhos médios de partículas das celuloses residuais das reações realizadas com polpa de sisal mercerizada $\left[80-100^{\circ} \mathrm{C}\right]$ e $[\mathrm{COOH}]_{2} 4,6 \mathrm{molL}^{-1}$, após 6 e 16h. Para estas medidas foi usado o equipamento MorFi Compact. 

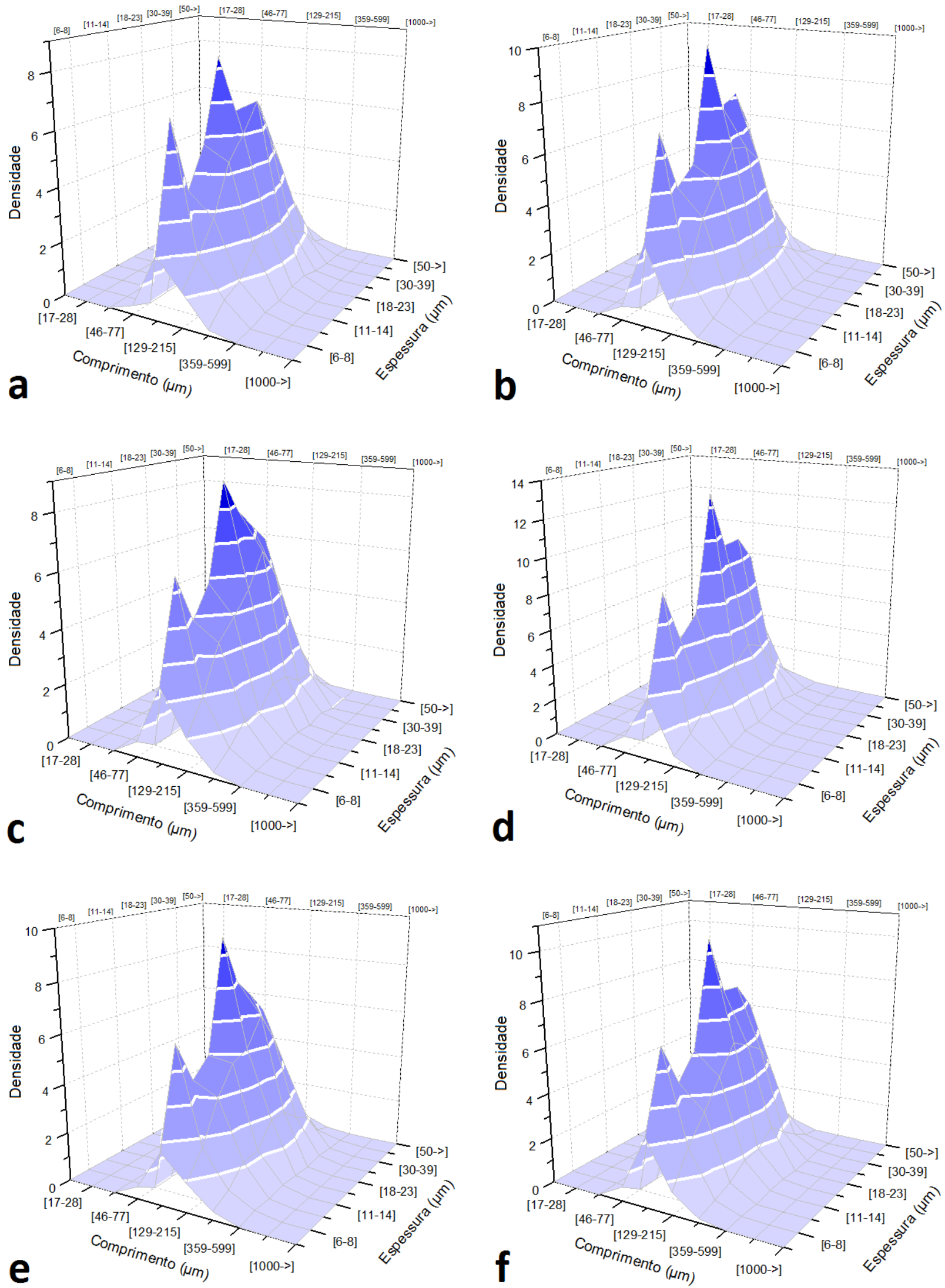

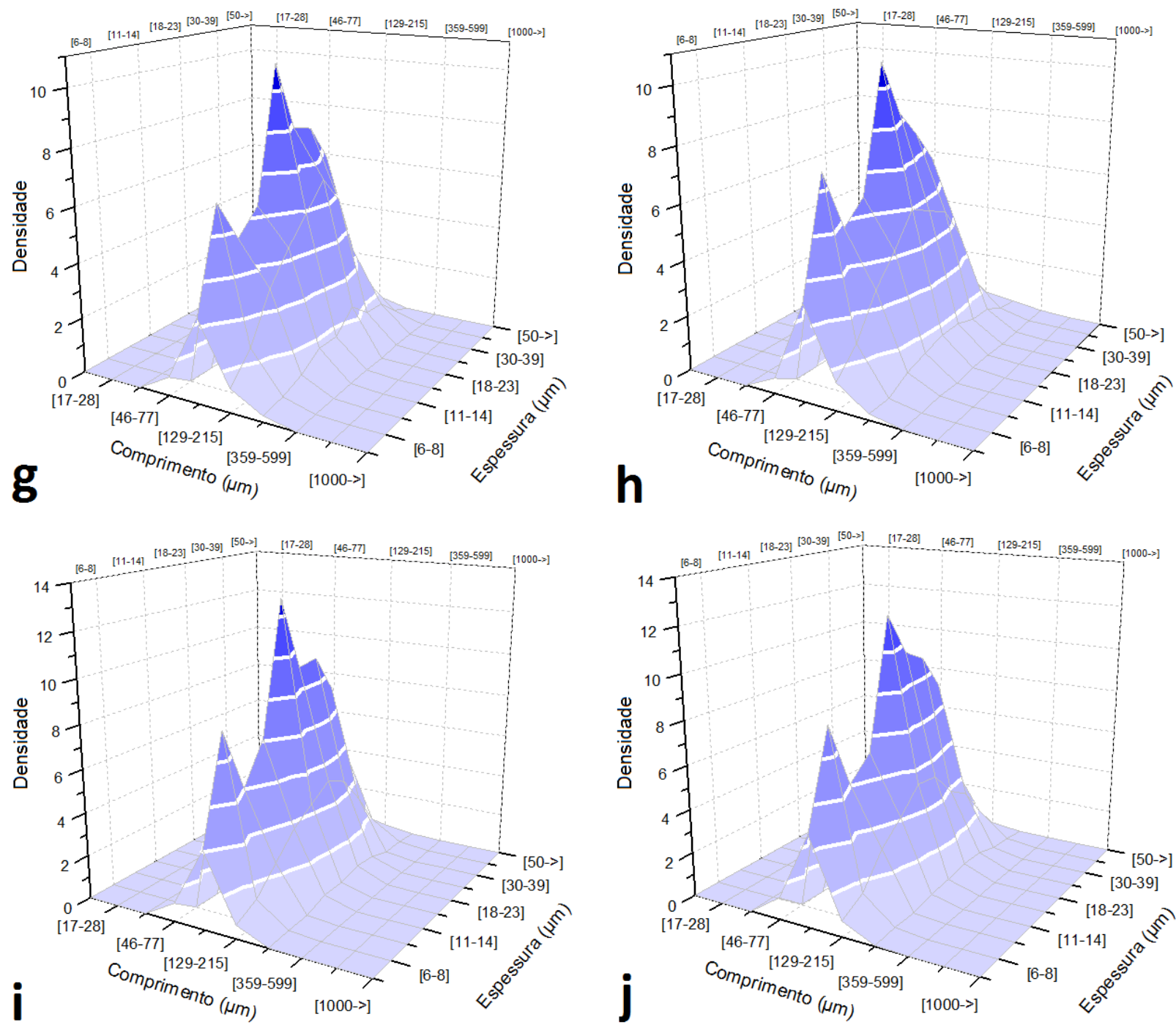

Figura 66 - Mapas de densidade referentes às celuloses residuais das reações de hidrólise com 4,6 molL $^{-1}$ de ácido oxálico e variação de temperatura, sendo: $[\mathbf{a}, \mathbf{b}] 80^{\circ} \mathrm{C},[\mathbf{c}, \mathbf{d}] 85^{\circ} \mathrm{C}$, $(\mathbf{e}, \mathbf{f}] 90^{\circ} \mathrm{C},[\mathbf{g}, \mathbf{h}] 95^{\circ} \mathrm{C}$, [i,j] $100^{\circ} \mathrm{C}$, para tempos iguais a $6 \mathrm{~h}$ e $16 \mathrm{~h}$, respectivamente.

Analogamente às reações utilizando ácido sulfúrico como catalisador, a hidrólise com ácido oxálico aumenta a população de fibras no sentido de menores comprimentos e espessuras, quando comparados à polpa de partida. Neste caso observa-se, a partir da Figura 66-a, que corresponde ao menor tempo de reação avaliado [6h] e à menor temperatura $\left(80^{\circ} \mathrm{C}\right.$ ], que o mapa de densidade apresenta maiores quantidades de fibras na faixa entre 129-215 $\mu \mathrm{m}$, quando comparadas a polpa de partida [Figura 25-b], o que significa que uma maior população de fibras possui, após a hidrólise, tamanhos menores. A variação da espessura das fibras com o tratamento ácido não apresenta um 
comportamento tão evidente quanto o mostrado para o comprimento, mas pode-se observar que partículas menos espessas vão sendo formadas com o aumento da temperatura e do tempo de exposição à solução ácida.

Ao compararmos os mapas de densidade das Figura 41-f e 64-i, através dos quais é possível avaliar as diferenças no comprimento e espessura das fibras quando ácido sulfúrico ou oxálico são usados nas mesmas condições, observa-se que com o uso do ácido sulfúrico, a densidade de fibras em tamanhos menores [entre 46 e $129 \mu \mathrm{m}$ ) aumenta mais intensamente, quando se compara com o uso do ácido oxálico. Entretanto, os maiores valores de espessura das fibras quando o ácido oxálico é usado como catalisador, indicados pela maior densidade de fibras em regiões de espessuras entre 18 e 39 um [Figura 66], podem ser devidos à aglomeração das fibras parcialmente hidrolisadas.

Análises de espalhamento de luz [FOQELS] foram realizadas a fim de avaliar a presença de partículas em escala nanométrica. Na Figura 67 encontra-se a distribuição dos tamanhos em função da quantidade de partículas, para as reações com ácido oxálico 4,6 molL $^{-1}$ e $100^{\circ} \mathrm{C}$. Para fins de comparação, o gráfico referente à reação HAS $\mathrm{t}=6 \mathrm{~h}$, também foi inserido. 


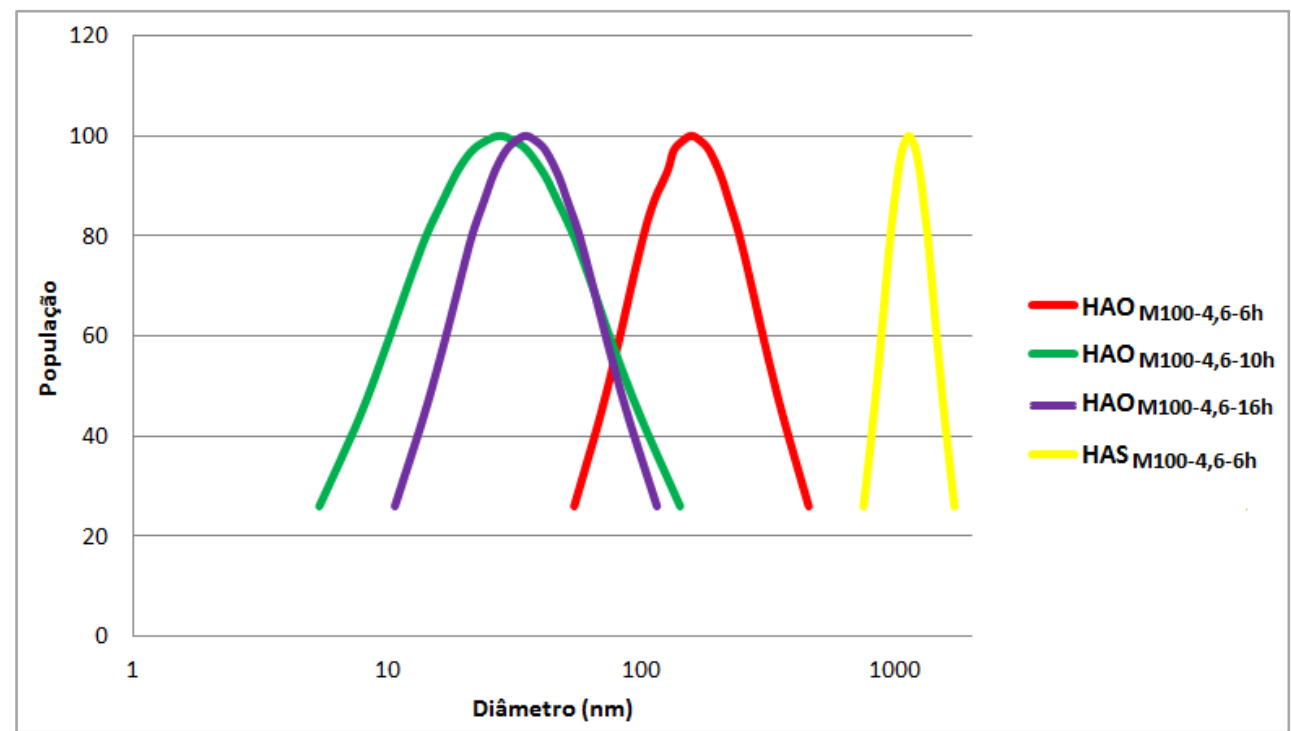

Figura 67 - Distribuição média dos tamanhos de partículas detectadas por espalhamento de luz.

A presença de partículas em escala nanométrica correspondente a material não reagido na reação de hidrólise usando ácido oxálico como catalisador nos leva a concluir que este ácido é um forte candidato para produção de nanofibras/nanopartículas que podem ser usadas em materiais para aplicações diversas. A grande vantagem do uso deste ácido, como já mencionado anteriormente, reside no fato de que este pode ser também produzido a partir de fontes renováveis.

\subsubsection{Caracterização dos produtos gerados nas reações de hidrólise}

Os açúcares e derivados que podem ser encontrados nos licores, formados nas reações de hidrólise, estão descritos na Tabela 11. 
Tabela 11 - Natureza dos possíveis açúcares e derivados que podem ser encontrados nos licores obtidos nas reações de hidrólise de polpa celulósica.

\begin{tabular}{|c|c|c|c|c|c|c|}
\hline $\begin{array}{c}\text { Produtos da } \\
\text { hidrólise de } \\
\text { celulose }\end{array}$ & $H A O_{\text {รт1000, }}$ & $H A O_{M 1004,6}$ & $H A O_{M 95-4,6}$ & $H_{A} O_{м 904,6}$ & $H A O_{M B 54,6}$ & $H A O_{\text {м80 }}$ \\
\hline Glicose & $\varnothing$ & $x$ & $x$ & $x$ & $x$ & $x$ \\
\hline HMF & $\varnothing$ & $x$ & $x^{*}$ & $x^{*}$ & $x^{*}$ & $x^{*}$ \\
\hline $\begin{array}{c}\text { Ácido } \\
\text { fórmico }\end{array}$ & $\varnothing$ & $x$ & $x$ & $x$ & $x$ & $x^{*}$ \\
\hline $\begin{array}{c}\text { Produtos da } \\
\text { hidrólise de } \\
\text { hemiceluloses }\end{array}$ & $H A O_{\text {รт1000, }}$ & $H A O_{\text {M1004,6 }}$ & $H A O_{M 954,6}$ & $H A O_{м 904,6}$ & $H_{A} O_{M B 54,6}$ & $H A O_{M 804,6}$ \\
\hline Xilose & $x$ & $x$ & $x$ & $x$ & $x$ & $x$ \\
\hline Arabinose & $\oslash$ & $\varnothing$ & $\varnothing$ & $\varnothing$ & $\varnothing$ & $\varnothing$ \\
\hline Ácido acético & $\varnothing$ & $\varnothing$ & $\varnothing$ & $\varnothing$ & $\varnothing$ & $\varnothing$ \\
\hline Furfural & $\theta$ & $x$ & $x$ & $x$ & $x^{*}$ & $x^{*}$ \\
\hline
\end{tabular}

x: detectado; Ø: não detectado

*não detectado para todos os tempos de reação

Da mesma maneira que foi observado quando as reações de hidrólise de polpa de sisal mercerizada foram catalisadas por ácido sulfúrico, para todas as condições houve formação de glicose, ou seja, todas as condições levaram à clivagem das ligações 1,4- $\beta$ glicosídicas das cadeias de celulose, diferindo na extensão em que ocorreram.

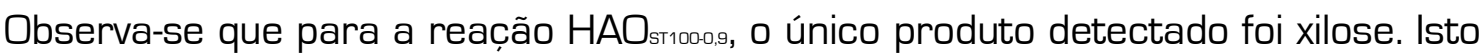
é explicado pela maior concentração de hemiceluloses presente na polpa que não é previamente mercerizada [Tabela 1]. A Figura 68 mostra a curva de produção de xilose em função do tempo, para esta reação. 


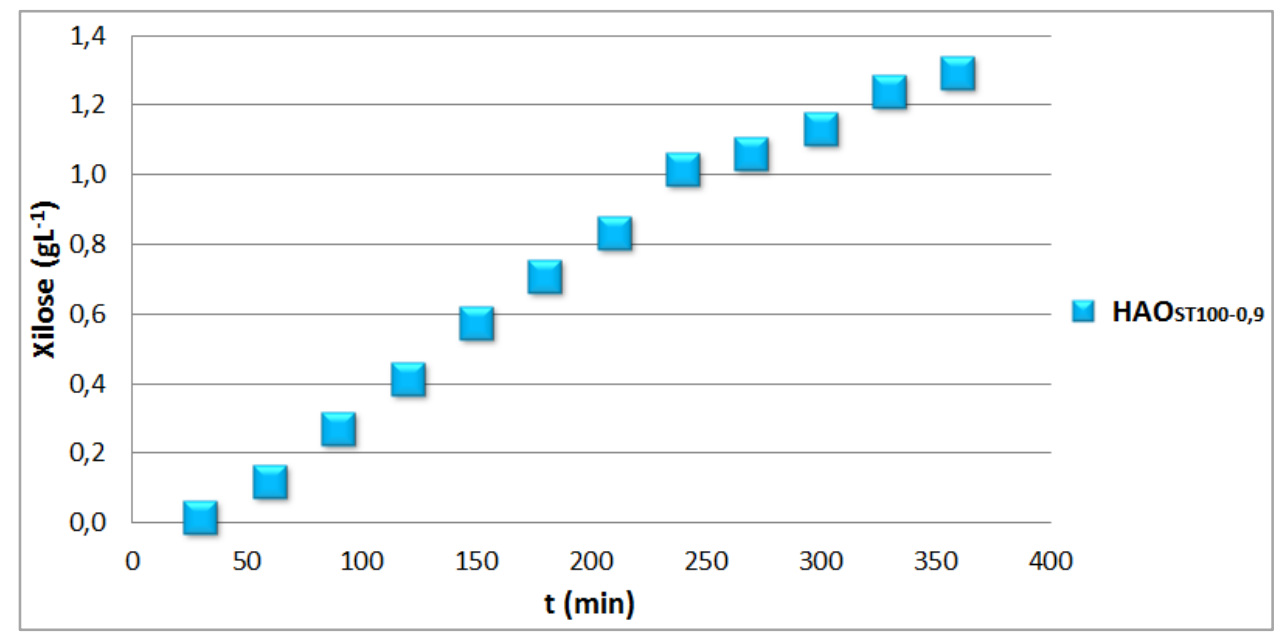

Figura 68 - Concentração de xilose em função do tempo para a reação $\mathrm{HAO}_{\text {ธт1000.9. }}$

Há um comportamento linear e crescente da concentração de xilose em função do tempo de exposição à solução ácida. Este resultado, aliado a não detecção de glicose no licor proveniente da hidrólise, indica que, nesta concentração, o ácido oxálico pode ser usado como um pré-tratamento para a eliminação das hemiceluloses presentes na polpa, que é essencial para que a polpa de sisal seja usada de maneira eficiente como fonte alternativa para a produção do bioetanol.

Ácido acético e arabinose, provenientes da hidrólise dos grupos presentes nas hemiceluloses, se presentes, estavam em concentração abaixo do limite mínimo de detecção do equipamento utilizado, tendo em vista o baixo teor de arabinose e grupos acetila nas hemiceluloses (Figura 10).

As Figura 69-74 ilustram a concentração dos produtos encontrados nas reações com 4,6 molL-1 $[\mathrm{COOH}]_{2}$ e variação de temperatura $\left[80-100^{\circ} \mathrm{C}\right]$.

As Figuras 69-72 são referentes à formação dos produtos provenientes da hidrólise de celulose, ou seja, glicose, HMF e ácido fórmico. 


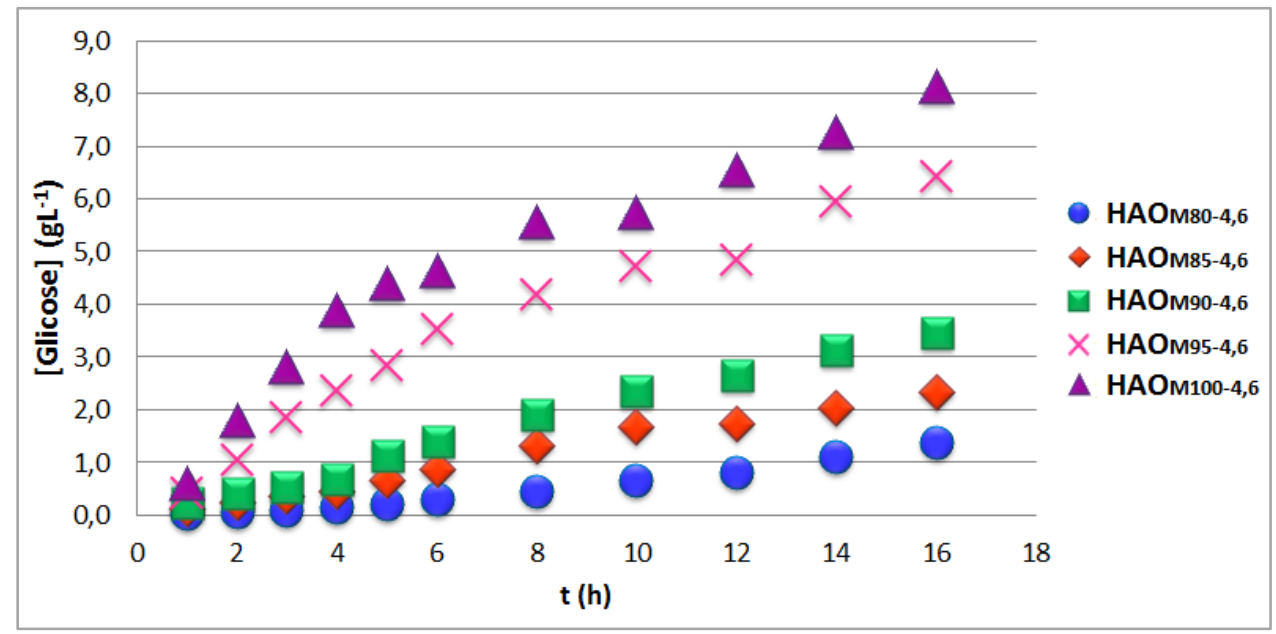

Figura 69 - Concentração de glicose encontrada no licor para as reações realizadas com 4,6 molL-1 de ácido oxálico $\left[80-100^{\circ} \mathrm{C}\right]$.

A produção de glicose está diretamente relacionada à temperatura do meio reacional, sendo que o valor máximo obtido foi aproximadamente $8,0 \mathrm{gL}^{-1}$, após $16 \mathrm{~h}$ de reação a $100^{\circ} \mathrm{C}$.

Quando se compara a concentração máxima de glicose formada com o uso ácido oxálico como catalisador, com a concentração máxima de glicose formada com o uso de ácido sulfúrico como catalisador, pode-se observar que o ácido sulfúrico leva a concentrações de glicose até quase 25\% maiores. Entretanto, quando este processo é utilizado não somente para a produção de glicose, mas também para a produção de nanofibras que possuem diversas aplicações, o ácido oxálico apresenta grande potencial de aplicação e certamente deve ser considerado para futuras aplicações como catalisador em hidrólise de celulose.

Na Figura 70 estão inseridas curvas de glicose potencial, ou seja, a quantidade de glicose que poderia ser detectada, nas condições consideradas, caso não fosse decomposta. Para isto, conforme mencionado anteriormente, além da glicose já presente no licor, a quantidade dos produtos da decomposição da glicose também é considerada, somando-se à concentração de glicose as respectivas concentrações de HMF e ácido fórmico [Figura 71 e Figura 72]. Os valores de glicose potencial correspondem a uma 
aproximação, pois estão sendo levadas em conta apenas as concentrações de HMF e ácido fórmico, ou seja, valores de concentração de ácido levulínico, também produto da decomposição de HMF, ou de outros produtos de decomposição que não foram analisados, não foram considerados para estes cálculos.

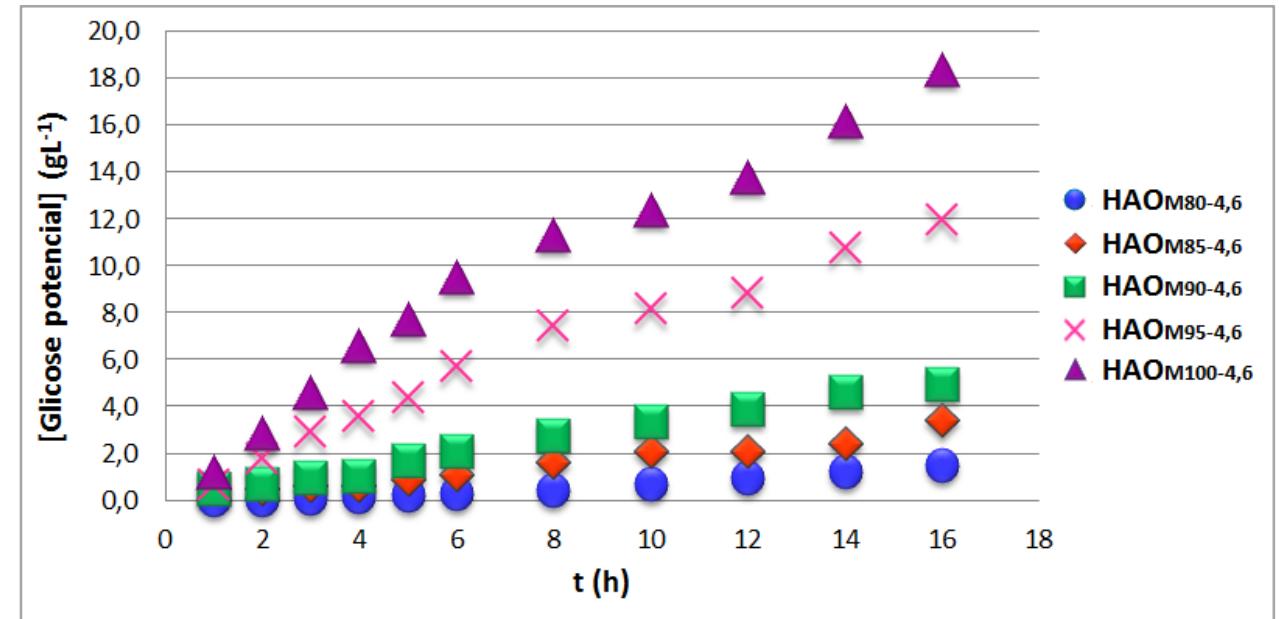

Figura 70 - Concentração de glicose potencial calculada para as reações realizadas com 4,6 moll-1 $[\mathrm{COOH}]_{2}\left(80-100^{\circ} \mathrm{C}\right)$.

Nota-se que a concentração hipotética de glicose, ou seja, a concentração de glicose que deveria ser detectada no licor caso não houvesse conversão desta a HMF e ácido fórmico [glicose potencial], é consideravelmente maior do que a concentração de glicose detectada, de fato, no licor contendo o material hidrolisado. Esta diferença é

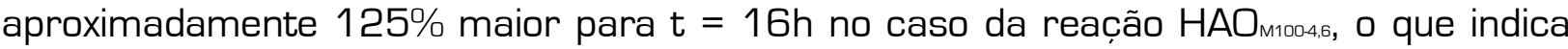
que mais que o dobro de toda glicose produzida nestas condições é convertida a produtos de decomposição.

A presença de HMF em todas as amostras analisadas [Tabela 11] indica que todas as condições de reação que partiram de polpa de sisal mercerizada levaram à decomposição parcial de glicose via reação de desidratação. A Figura 71 mostra as concentrações de HMF detectadas nas reações estudadas. 


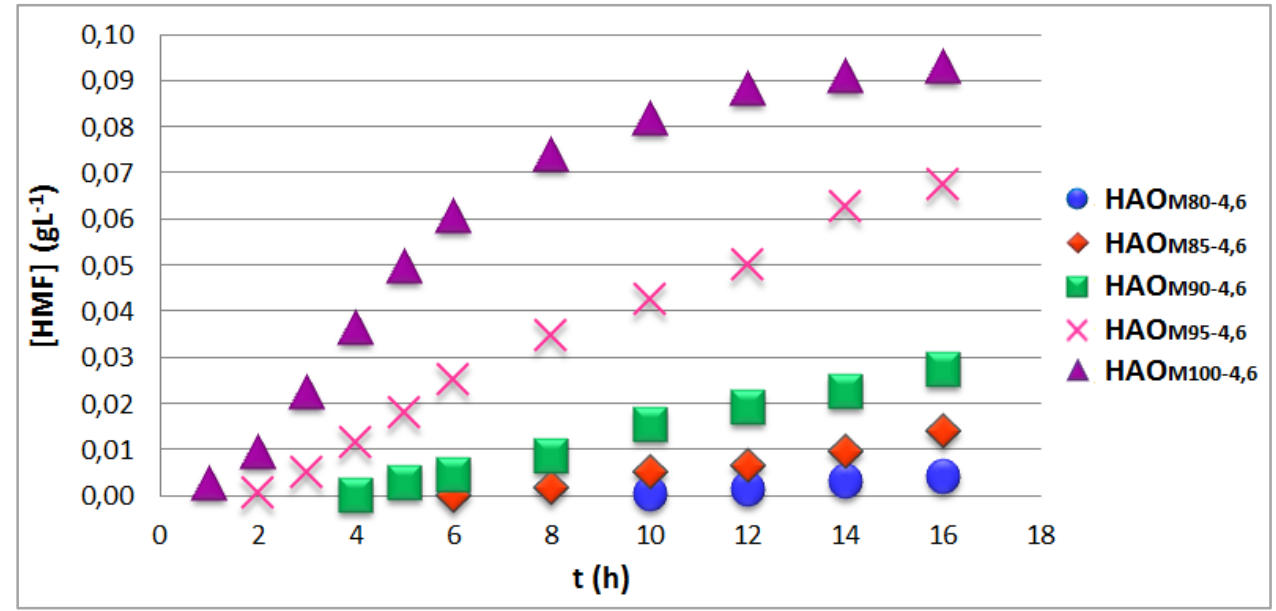

Figura 71 - Concentração de HMF no licor em função do tempo de hidrólise.

Observa-se que o aumento da temperatura favoreceu a desidratação da glicose, acarretando em aumento da produção de HMF [Figura 71]. Nota-se que em $\mathrm{HAO}_{\text {мв०4,6}}$ praticamente não há formação de HMF, e apenas a partir de 10h de reação uma pequena fração é detectada $\left[0,005 \mathrm{gL}^{-1}\right]$. Em contrapartida, em $\mathrm{HAO}_{\mathrm{m1004,6}} \mathrm{O}$ valor da concentração de HMF chega a aproximadamente $0,08 \mathrm{gL}^{-1}$, neste mesmo intervalo de tempo.

O ácido fórmico foi detectado em todas as temperaturas avaliadas, sendo que para $\mathrm{T}=80^{\circ} \mathrm{C}$, esta substância estava presente no licor apenas a partir de $t=8 \mathrm{~h}$. $\mathrm{A}$ Figura 72 mostra a evolução da concentração de ácido fórmico no licor em função do tempo para as reações estudadas.

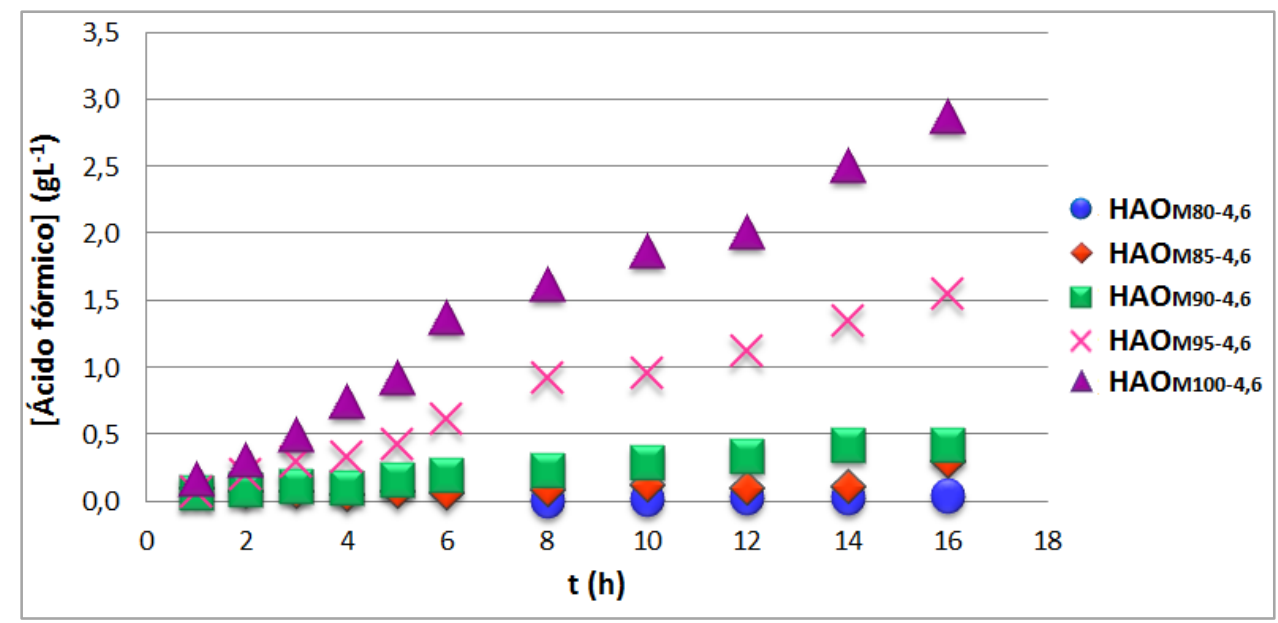

Figura 72 - Concentração de ácido fórmico no licor em função do tempo de hidrólise. 
É possivel notar que no caso das reações feitas a 95 e $100^{\circ} \mathrm{C}$, é grande a diferença de concentração de ácido fórmico em relação ao HMF (Figura 71 e Figura 72). Este fato é justificado, pois a estabilidade do HMF nestas condições é extremamente baixa, levando à formação de ácido fórmico e levulínico [não analisado].

As Figuras 73 e 74 são referentes à formação dos produtos provenientes da hidrólise das hemiceluloses, ou seja, xilose e furfural. Arabinose e ácido acético não foram detectados em nenhuma das reações avaliadas, conforme descrito na Tabela 11.

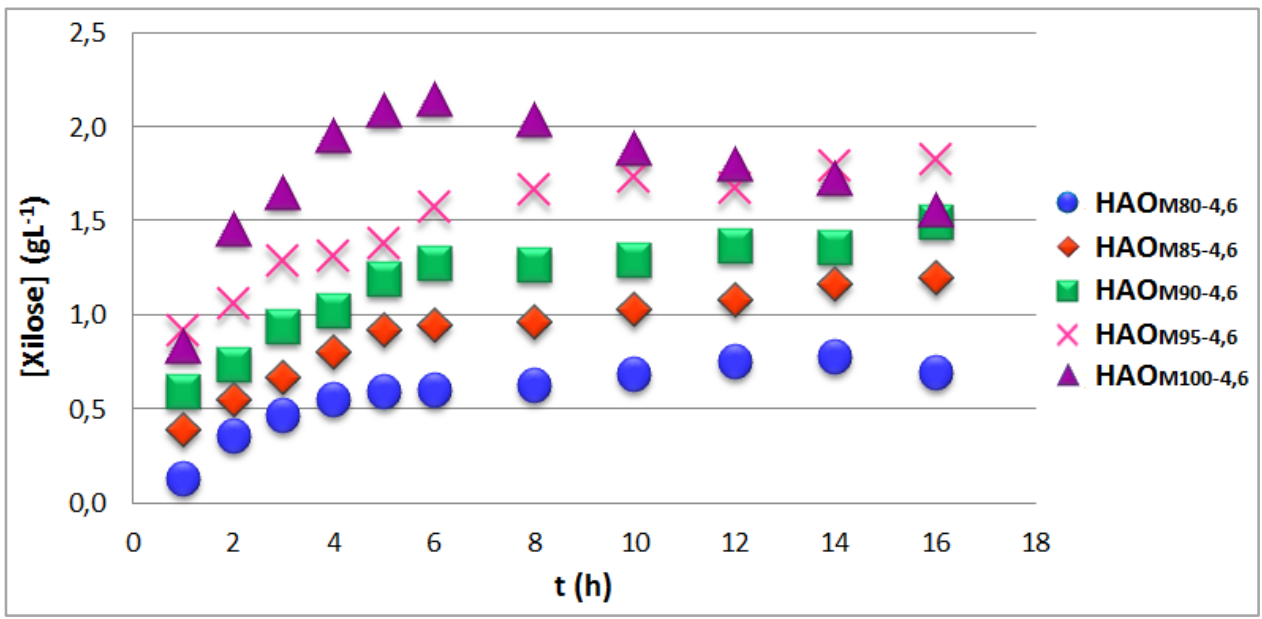

Figura 73 - Concentração de xilose no licor em função do tempo de hidrólise.

Nota-se que nas reações $\mathrm{HAO}_{\text {мв04,6, }}, \mathrm{HAO}_{\text {м954,6, }}, \mathrm{HAO}_{\text {м904,6, }}$ e $\mathrm{HAO}_{\text {м954,6, }}$ a concentração de xilose aumenta até aproximadamente 10h, mantendo-se constante em seguida. Por outro lado, para $\mathrm{HAO}_{\text {m1004,6, }}$ observa-se um aumento da concentração de xilose até aproximadamente 6h de reação, ocorrendo decomposição na sequência, conforme evidenciado pela diminuição na concentração observada. Estes resultados indicam que na presença de 4,6 $\mathrm{molL}^{-1}[\mathrm{COOH}]_{2}$ a xilose é relativamente estável a temperaturas entre 80 e $95^{\circ} \mathrm{C}$, e mais instável a partir de $100^{\circ} \mathrm{C}$. 
Todas as condições reacionais levaram à decomposição da xilose, fato comprovado pela presença de furfural em todos os licores obtidos, conforme ilustrado pela Figura 74.

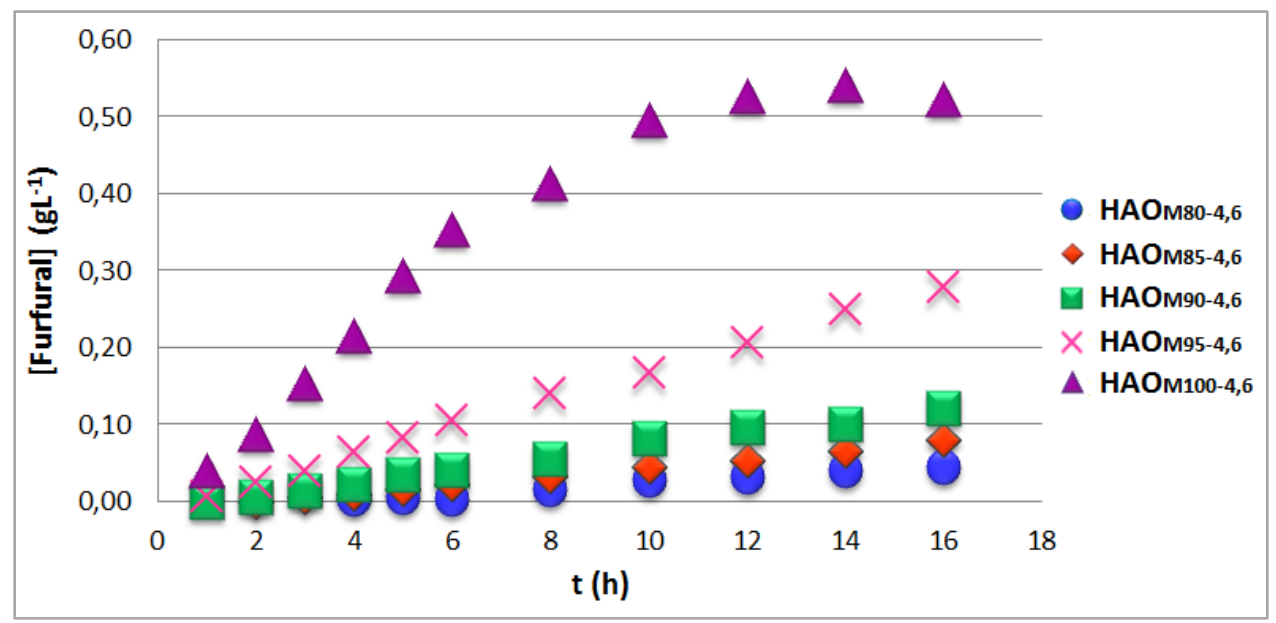

Figura 74 - Concentração de furfural no licor em função do tempo de hidrólise.

O aumento da temperatura de 80 para $100^{\circ} \mathrm{C}$ levou a um considerável aumento da produção de furfural no meio reacional [Figura 74). Ainda, observando o perfil das curvas, nota-se que, aparentemente, $\mathrm{HAO}_{\mathrm{m} 1004,6}$ alcançou um limite máximo de concentração em $t=14 \mathrm{~h}$ e, a partir daí, a taxa de formação é menor que a de decomposição, e a concentração de furfural em t = 16h é menor que o máximo atingido. Este fato provavelmente está relacionado à formação de produtos de condensação, favorecida nesta condição [Figura 31-b].

Os gráficos a seguir mostram o ajuste não-linear do modelo de Saeman para as curvas de concentração de glicose em função da temperatura de reação. Os valores de $k_{1}, k_{2}$ e $R^{2}$ referentes a cada reação estão expressos na Tabela $12 .$.

Como descrito em seção anterior, para que o modelo fosse aplicado às curvas experimentais de concentração de glicose, o software OriginPro 8 SRO versão 8.0724 [B724] foi utilizado. A glicose gerada pela hidrólise da hemicelulose não foi considerada isoladamente, por se tratar de quantidade não significativa, conforme já mencionado. 

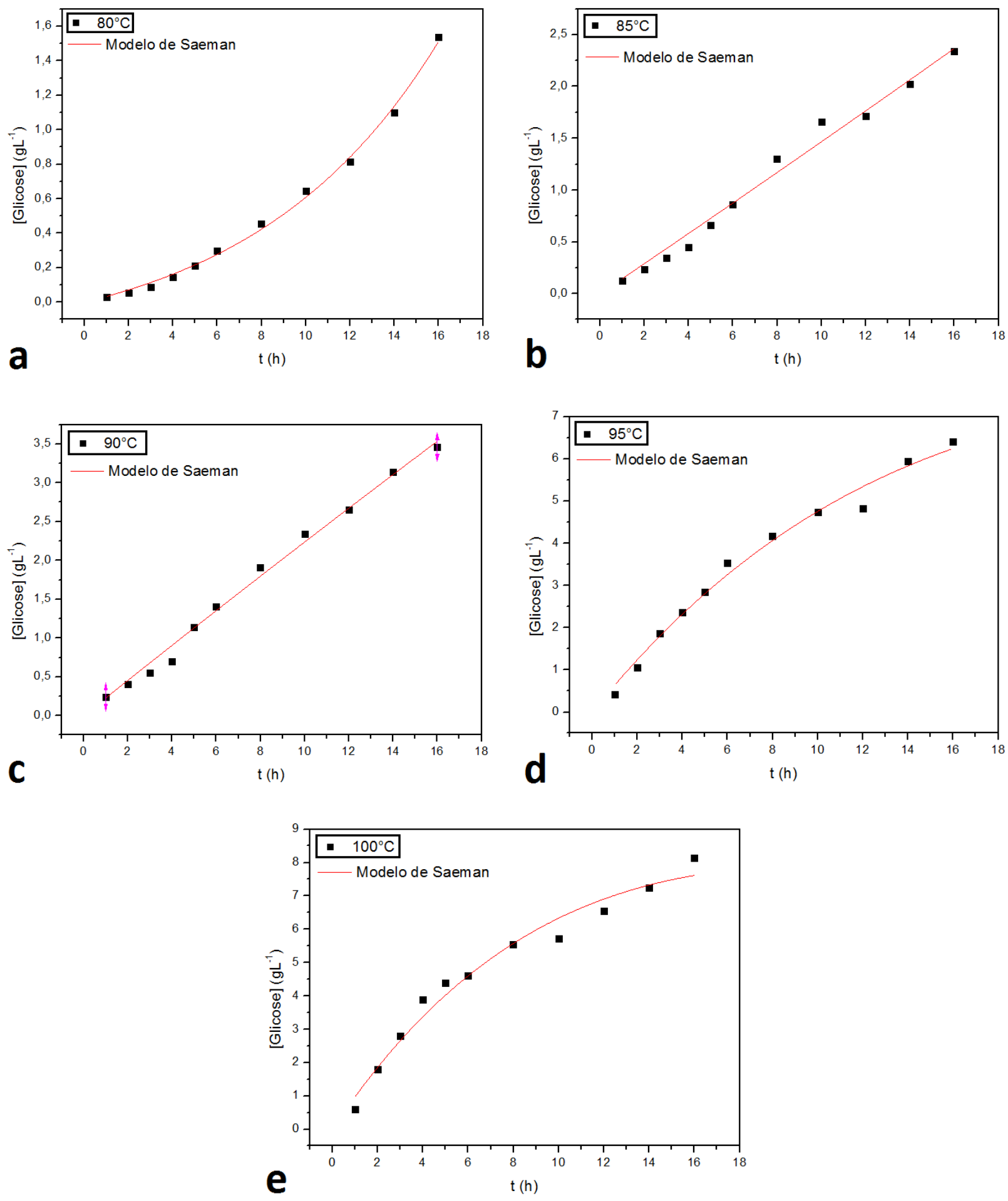

Figura 75 - Ajuste não-linear do modelo de Saeman para reações de hidrólise ácida de celulose com ácido oxálico 4,6 $\mathrm{molL}^{-1}$ e celulose mercerizada $\left[\mathrm{T}=80-100^{\circ} \mathrm{C}\right.$ ]. 
Tabela 12 - Constantes de hidrólise de celulose $\left[k_{1}\right]$, decomposição de glicose [ $\left.k_{2}\right]$ e valor de $R^{2}$.

\begin{tabular}{|c|c|c|c|c|c|}
\hline & $\mathrm{HAO}_{\text {м804,6}}$ & $\mathrm{HAO}_{\mathrm{M85-4,6}}$ & $\mathrm{HAO}_{\text {м90-4,6}}$ & $\mathrm{HAO}_{\mathrm{M95-4,6}}$ & 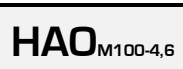 \\
\hline$k_{1} \times 10^{3}$ & 1,0 & 4,7 & 7,4 & 21,4 & 33,1 \\
\hline$k_{2} \times 10^{3}$ & 0,0 & 0,0 & 0,0 & 4,6 & 6,4 \\
\hline $\mathrm{R}^{2}$ & 0,996 & 0,983 & 0,992 & 0,986 & 0,972 \\
\hline
\end{tabular}

Comparando-se a Tabela 9, referente aos valores de $k_{1}, k_{2}$ e $R^{2}$ obtidos para as reações com $\mathrm{H}_{2} \mathrm{SO}_{4}$ [60-100 $\mathrm{C}$, com a Tabela 12, nota-se grandes diferenças nos valores das constantes cinéticas de formação e decomposição de glicose. Deve-se destacar que no caso das reações usando ácido sulfúrico como catalisador, as alíquotas foram retiradas durante um intervalo de tempo de 6h, enquanto que para o ácido oxálico o primeiro ponto correspondeu a $\mathrm{t}=1 \mathrm{~h}$, estendendo até $16 \mathrm{~h}$.

Os valores de $k_{1}$ e k2 calculados para a reação com ácido sulfúrico nas mesmas condições são menores do que aqueles obtidos para reação com ácido oxálico. Um resultado importante e que merece destaque no caso das reações realizadas com ácido oxálico é que, diferentemente do ácido sulfúrico, os valores de k` são sempre maiores do que os valores de $k_{2}$, indicando uma menor tendência de decomposição da glicose quando este catalisador é usado nas reações de hidrólise de polpa celulósica. Estes resultados estão na mesma escala de magnitude dos apresentados por Aguilar e colaboradores [AGUILAR et al., 2002], que obtiveram valores de $\mathrm{k}_{1} \times 10^{3}$ e $\mathrm{k}_{2} \times 10^{3}$ respectivamente iguais a 35,7 e 0,29 para reações de hidrólise de bagaço de cana-de-açúcar usando $\mathrm{H}_{2} \mathrm{SO}_{4} 2 \%$ como catalisador, a $122^{\circ} \mathrm{C}$.

A partir da lei geral de Arrhenius [Equação 15], em que a velocidade da reação é relacionada à temperatura, a energia de ativação para hidrólise ácida de celulose de sisal pode ser calculada para as condições do presente trabalho. Assim, foi gerado um gráfico 
(Figura 76) do logaritmo de $k_{1}$ em função do inverso da temperatura absoluta para a obtenção do valor de $E_{a}$.

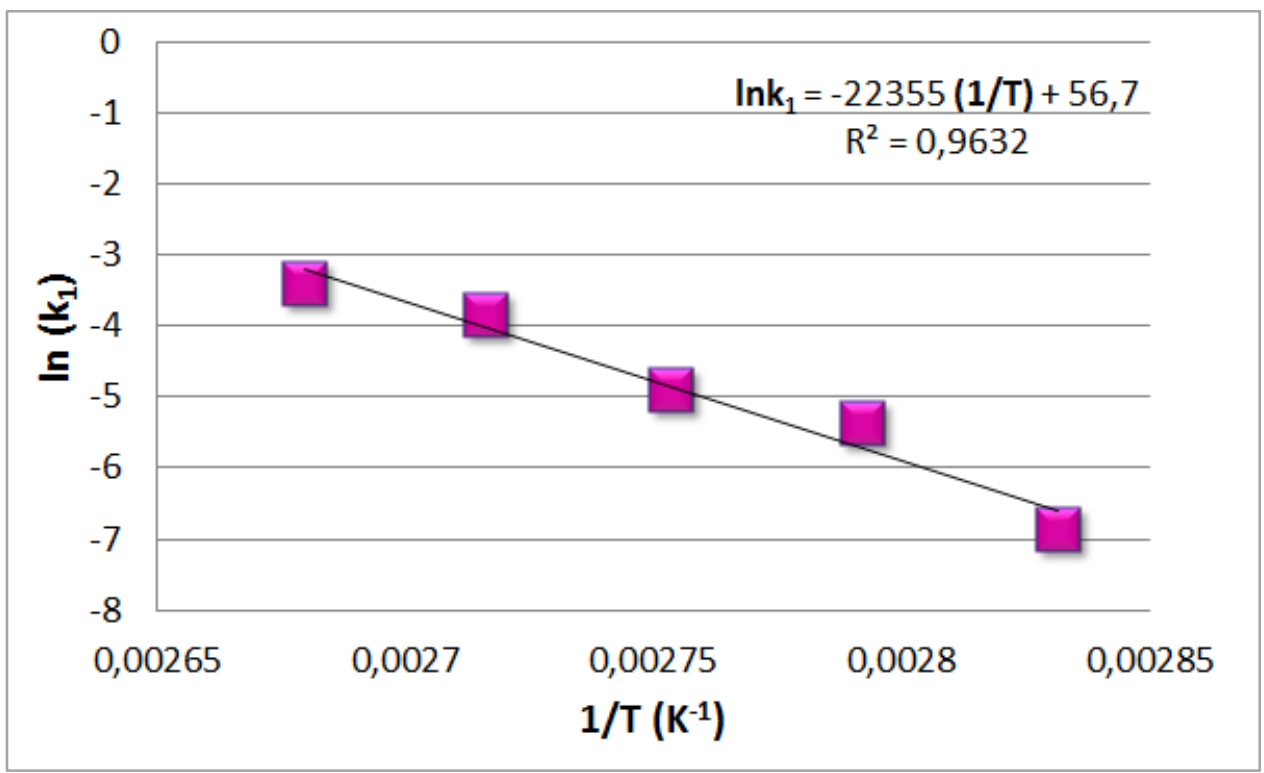

Figura 76 - Gráfico de Arrehnius para hidrólise ácida de celulose de sisal $[80$ - 100 e 4,6 molL $\left.[\mathrm{COOH}]_{2}\right]$.

Portanto, a partir da Figura 76, tem-se que $\mathrm{E}_{\mathrm{a}}=185,9 \mathrm{kJmol}^{1}$.

O valor calculado para $E_{a}$ é maior do que aquele observado para a reação com ácido sulfúrico nas mesmas condições $\left[E_{a}=129 \mathrm{kJmol}^{-1}\right]$, o que pode ser justificado pelo menor grau de ionização do ácido oxálico, uma vez que, apesar das concentrações molares dos ácidos sulfúrico e oxálico serem as mesmas [4,6 molL-1], a concentração de íons $\mathrm{H}^{+}$, que são as espécies que de fato catalisam a reação de hidrólise ácida de celulose, são diferentes para cada ácido. A maior concentração de $\mathrm{H}^{+}$no meio em que ácido sulfúrico está presente garante um maior número de choques efetivos entre os prótons e as cadeias de celulose, fazendo com que a barreira energética que deve ser superada para que ocorra a hidrólise das cadeias de celulose seja comparativamente menor. 


\subsubsection{RENDIMENTOS DA HIDRÓLISE ÁCIDA DE POLPA DE SISAL}

Considerando o total de celulose pura presente na massa inicial (Tabela 1], é possível calcular o rendimento das reaccões de hidrólise ácida de polpa de sisal. Para isso, foi calculado o máximo que seria obtido de glicose se toda celulose fosse hidrolisada a glicose [glicose potencial], e não houvesse decomposição, com o uso da Equação 17:

$$
[\text { glicose }]_{\max }=\frac{M_{i} \times \% \text { cel } \times q}{V}
$$

Sendo:

$$
q=\frac{M M_{\text {glicose }}}{M M_{\text {anidrogliose }}}=\frac{180 \mathrm{gmol}^{-1}}{162 \mathrm{gmol}^{-1}}=1,1
$$

- "q" é um fator de conversão necessário para calcular o quanto de glicose seria formada a partir da celulose inicial, já que na celulose, glicose está na forma anidra, ou seja, difere, em massa, por uma molécula de água;

- $M_{i}=$ Massa inicial de polpa celulósica [para todos os casos $M_{i}=30 g$ ]

- $V=$ volume da solução [para todos os casos $V=0,9 L$ ]

- \%cel = porcentagem de celulose na polpa.

Estes cálculos forneceram o valor de 35,9 $\mathrm{gL}^{-1}$ de glicose no licor, ou seja, potencialmente, se toda a celulose fosse convertida em glicose, e se não houvesse decomposição, este valor deveria ser detectado via CLAE.

Em posse deste valor, é possivel calcular, portanto, o rendimento das reações estudadas. Para isso, foram feitos cálculos tendo como base, os máximos valores de concentração de glicose obtidos para cada condição reacional. Para obter a porcentagem de celulose hidrolisada foi calculada a razão entre glicose potencial (glicose do licor 
somada aos produtos de decomposição], com a concentração máxima de glicose [que seria obtida se toda celulose fosse hidrolisada, tendo como produto a glicose). As Equações 19 e 20 indicam como foram feitos os cálculos.

$$
\% \text { de celulose hidrolisada }=\frac{[\text { gli } \cos e]_{\text {potencial }}}{[\text { gli } \cos e]_{\max }} \times 100
$$

E a porcentagem de celulose convertida em glicose que não se decompôs no licor é:

$$
\% \text { de celulose convertida em glicose }=\frac{[\text { gli cos } e]_{\text {licor }}}{[\text { gli } \cos e]_{\max }} \times 100
$$

A Tabela 13 resume os valores obtidos através dos cálculos acima descritos.

Tabela 13 - Valores de glicose máxima, glicose potencial e porcentagem de celulose hidrolisada a

\begin{tabular}{|c|c|c|c|}
\hline & $H A S_{s т 1004,6}$ & $\mathrm{HAS}_{\mathrm{M} 1004,6}$ & $\mathrm{HAO}_{\mathrm{M} 100-4,6}$ \\
\hline $\begin{array}{c}\text { Glicose máxima } \\
{\left[\mathrm{gL}^{-1}\right]}\end{array}$ & 32,3 & 35,9 & 35,9 \\
\hline Tempo [h] & 5 & 5,5 & 18 \\
\hline $\begin{array}{c}\text { Glicose potencial } \\
{\left[\mathrm{gL}^{-1}\right]}\end{array}$ & 12,8 & 14,4 & 18,1 \\
\hline $\begin{array}{l}\text { Glicose no licor } \\
{\left[\mathrm{gL}^{-1}\right]}\end{array}$ & 7,4 & 10,2 & 8,0 \\
\hline $\begin{array}{l}\% \text { de celulose } \\
\text { hidrolisada }\end{array}$ & 39,6 & 40,1 & 50,4 \\
\hline $\begin{array}{c}\% \text { de celulose } \\
\text { convertida a glicose }\end{array}$ & 22,9 & 28,4 & 22,3 \\
\hline
\end{tabular}
glicose para as reações $\mathrm{HAS}_{\mathrm{s} 11004,6,} \mathrm{HAS}_{\mathrm{M1004,4}} \mathrm{e}$ HAO $\mathrm{H}_{1004,6 .}$

Observa-se a partir da Tabela 13 que a reação usado ácido sulfúrico e polpa mercerizada possibilitou um maior rendimento quando comparado ao ácido oxálico, fato que já era esperado devido ao menor $\mathrm{pK}_{\mathrm{a}}$ do ácido oxálico e ao maior teor de $\alpha$-celulose 
presente na polpa mercerizada. Entretanto, deve-se salientar que o ácido oxálico possui uma grande vantagem frente ao ácido sulfúrico, que é a de poder ser produzido a partir de fontes renováveis, o que torna o processo da hidrólise, como um todo, favorável. 


\subsubsection{REACCÕES DE HIDROLISE ENZIMATICA}

Conforme descrito anteriormente, nesta etapa do trabalho as reações de hidrólise enzimática foram realizadas visando à produção de açúcares fermentescíveis, primeira etapa da produção do bioetanol. Para isso, dois pré-tratamentos da polpa de sisal foram avaliados para fins de comparação frente à eficiência dos mesmos na posterior reação de hidrólise enzimática, visando à produção destes açúcares: mercerização e tratamento com ácido oxálico 0,9 molL.

Analogamente às reações de hidrólise catalisadas por ácido, foram analisadas as modificações decorrentes da hidrólise enzimática, tanto no licor contendo o material hidrolisado, quanto nas fibras residuais que não foram totalmente hidrolisadas, sendo que estes foram separados por filtração simples.

Na Tabela 14 encontram-se os códigos usados para denominar as reações de hidrólise enzimática, e as respectivas concentrações de enzima, informadas em unidades de mililitros do complexo enzimático por grama de polpa celulósica. Todas as reações foram feitas a temperatura constante e igual a $50^{\circ} \mathrm{C}$.

Tabela 14 - Códigos usados para denominar as reações estudadas $\left[50^{\circ} \mathrm{C}\right]$ de acordo com as condições empregadas.

\begin{tabular}{|c|c|c|}
\hline Código & $\begin{array}{l}\text { Pré-tratamento da } \\
\text { polpa }\end{array}$ & $\begin{array}{l}\text { Concentracão de enzima } \\
\qquad(\mathrm{mL} / \mathrm{g}]\end{array}$ \\
\hline $\mathrm{HE}_{\text {м50.0.1 }}$ & Mercerização & 0,1 \\
\hline $\mathrm{HE}_{\text {м50.0,3 }}$ & Mercerização & 0,3 \\
\hline $\mathrm{HE}_{\mathrm{M500,5}}$ & Mercerização & 0,5 \\
\hline $\mathrm{HE}_{\mathrm{A0500,0}, 1}$ & Ácido oxálico 0,9 moll-1 & 0,1 \\
\hline $\mathrm{HE}_{\mathrm{A0500,3}, 3}$ & Ácido oxálico 0,9 molL-11 & 0,3 \\
\hline $\mathrm{HE}_{\mathrm{A0500,5}, 5}$ & Ácido oxálico 0,9 moll-1 & 0,5 \\
\hline
\end{tabular}

Conforme mencionado na Tabela 1, a polpa mercerizada possui índice de cristalinidade igual a 69\%, massa molar média de 99900 gmol $^{-1}$, e teor de $\alpha$-celulose de 
98\%. Os valores correspondentes à polpa tratada com ácido oxálico 0,9 $\mathrm{molL}^{-1}$ são, respectivamente, 83\%, $16100 \mathrm{gmol}^{-1}$ e 94\%.

O tratamento com ácido oxálico levou a uma significativa diminuição na massa molar média, pois a polpa de partida tem $\mathrm{MM}_{\text {vis }}=115700 \mathrm{gmol}^{-1}$, o que é decorrente de hidrólise parcial das cadeias de celulose provavelmente presentes em domínios não cristalinos, gerando cadeias menores. A cristalinidade aumentou de 77\% [Tabela 1] para 83\%, enquanto que o tratamento de mercerização diminuiu este parâmetro para 69\%. Estes resultados podem indicar que as cadeias menores geradas pela hidrólise em meio ácido se reorganizaram, gerando novos domínios cristalinos, aumentando assim a cristalinidade. Os resultados para os teores de $\alpha$-celulose mostraram que houve um aumento significativo no teor de celulose pura após o tratamento da mercerização [ $\alpha$ celulose $=98 \%$, decorrente da eliminação de hemiceluloses, e o ácido oxálico foi menos eficiente neste sentido [ $\alpha$-celulose $=94 \%$.

A Figura 77 mostra as micrografias das polpas de partida usadas nas reações de hidrólise enzimática, ou seja, mercerizadas e tratadas com ácido oxálico 0,9 molL-1.

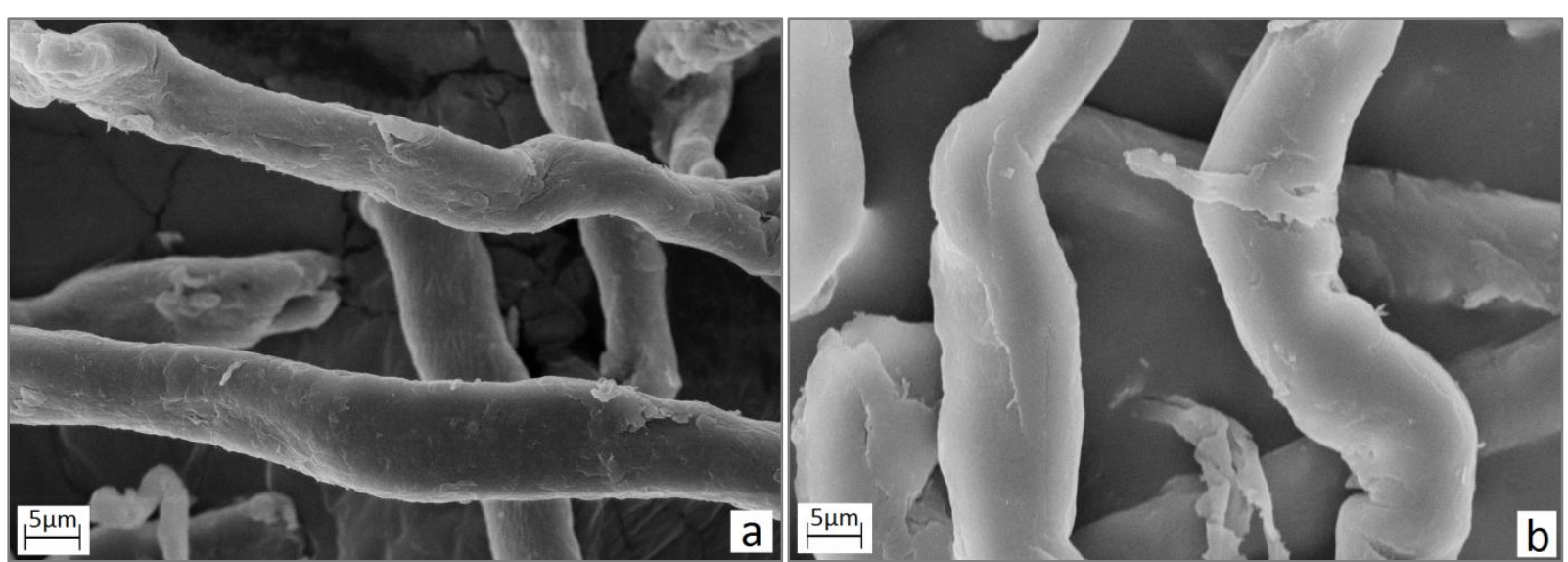

Figura 77 - Micrografias das fibras de celulose de sisal mercerizada [a] e tratada com ácido oxálico 0,9 molL $^{-1}$ [b]. 
É possível observar pelas micrografias apresentadas [Figura 77) que as fibras que passaram pelo tratamento da mercerização possuem superfícies mais rugosas, comparativamente àquelas tratadas com ácido oxálico, que são mais lisas. Estas "rugosidades" presentes nas fibras mercerizadas são importantes já que, em se tratando de reação em meio heterogêneo, fazem com que a superfície de contato entre a solução ácida e as fibras de celulose aumente, favorecendo a reação.

\subsubsection{Caracterização da polpa residual}

As celuloses residuais de cada reação foram caracterizadas quanto aos valores de índice de cristalinidade por difração de raios X e massa molar média por viscosimetria, e a morfologia das fibras foi acessada por microscopia eletrônica de varredura.

Nas Figura 78 e 79 estão mostrados os valores de massa molar média viscosimétrica e índice de cristalinidade das polpas residuais [não reagidas] após reações de hidrólise. 

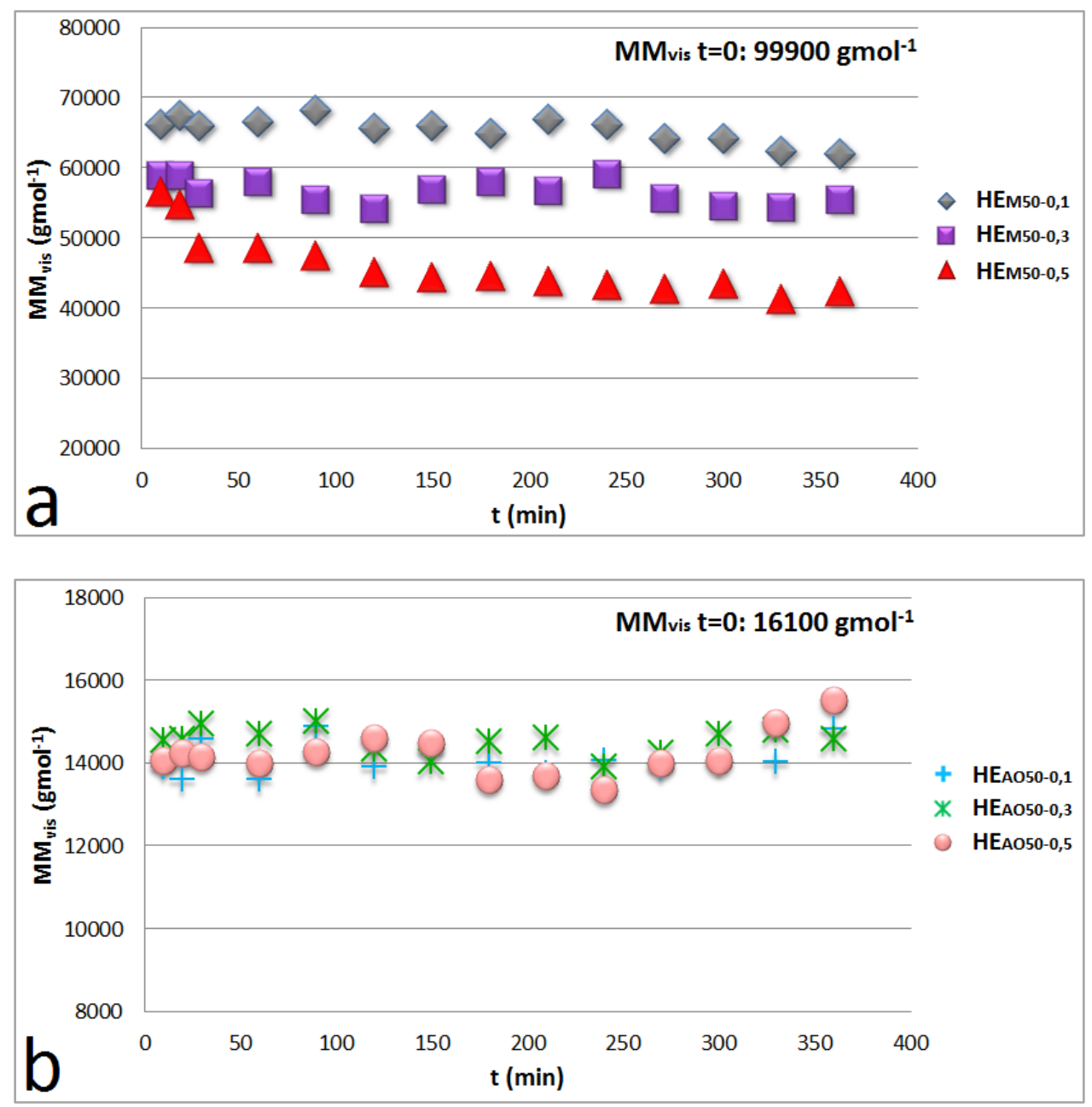

Figura 78 - Valores de massa molar média viscosimétrica das polpas residuais das reações de hidrólise enzimática partindo de [a] polpa mercerizada e [b] polpa tratada com ácido oxálico 0,9 molL.

Para a polpa mercerizada, nota-se que a catálise enzimática promove uma queda no valor de massa molar média da polpa celulósica logo nos minutos iniciais da reação, mais evidente para concentrações de enzima igual a 0,3 e 0,5 $\mathrm{mLg}^{-1}$ [Figura 78-a) sendo que este valor permanece constante após determinado tempo e até o tempo total estudado [6h]. Entretanto, quando se compara os dois pré-tratamentos aplicados na polpa de partida [mercerização e tratamento com ácido oxálico], observa-se que, no caso da mercerização, esta queda inicial no valor de massa molar média é de aproximadamente $35 \%$ para a reação $\mathrm{HE}_{\mathrm{M50-0,1}}$, e de aproximadamente $14 \%$ no caso da

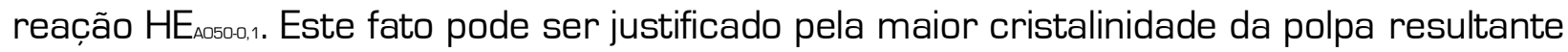
do tratamento com ácido oxálico, o que dificulta sobremaneira o acesso das enzimas às 
cadeias de celulose. Além disso, a maior rugosidade das fibras mercerizadas possivelmente também exerceu influência sobre o acesso das enzimas e, portanto, sobre os valores de massa molar média das polpas residuais. Outra diferença interessante entre a catálise ácida e a catálise enzimática, é que a menor massa molar média obtida via catálise enzimática, no caso da polpa mercerizada, foi de aproximadamente 40000 gmol $^{-1}$, que é um valor consideravelmente maior do que aqueles obtidos por catálise ácida [aproximadamente $6000 \mathrm{gmol}^{-1}$ quando $4,6 \mathrm{molL}^{-1}$ de ácido oxálico foi usado como catalisador, a $100^{\circ} \mathrm{C}$ e $\mathrm{t}=16 \mathrm{~h}$ ]. Este fato também pode ser justificado pelo aumento da cristalinidade da polpa não hidrolisada residual presente no meio reacional logo no início da reação, conforme discutido a seguir (Figura 79], sendo que as enzimas se mostram mais sensíveis a esta característica do que o ácido. É importante mencionar que, no caso da reação $\mathrm{HEAO}_{50-0,5}$, o pequeno aumento no valor de $\mathrm{MM}_{\text {vis }}$ nos minutos finais de reação se deve a erros de medida que, neste caso, variam entre 1,18 e 9,04\%. 

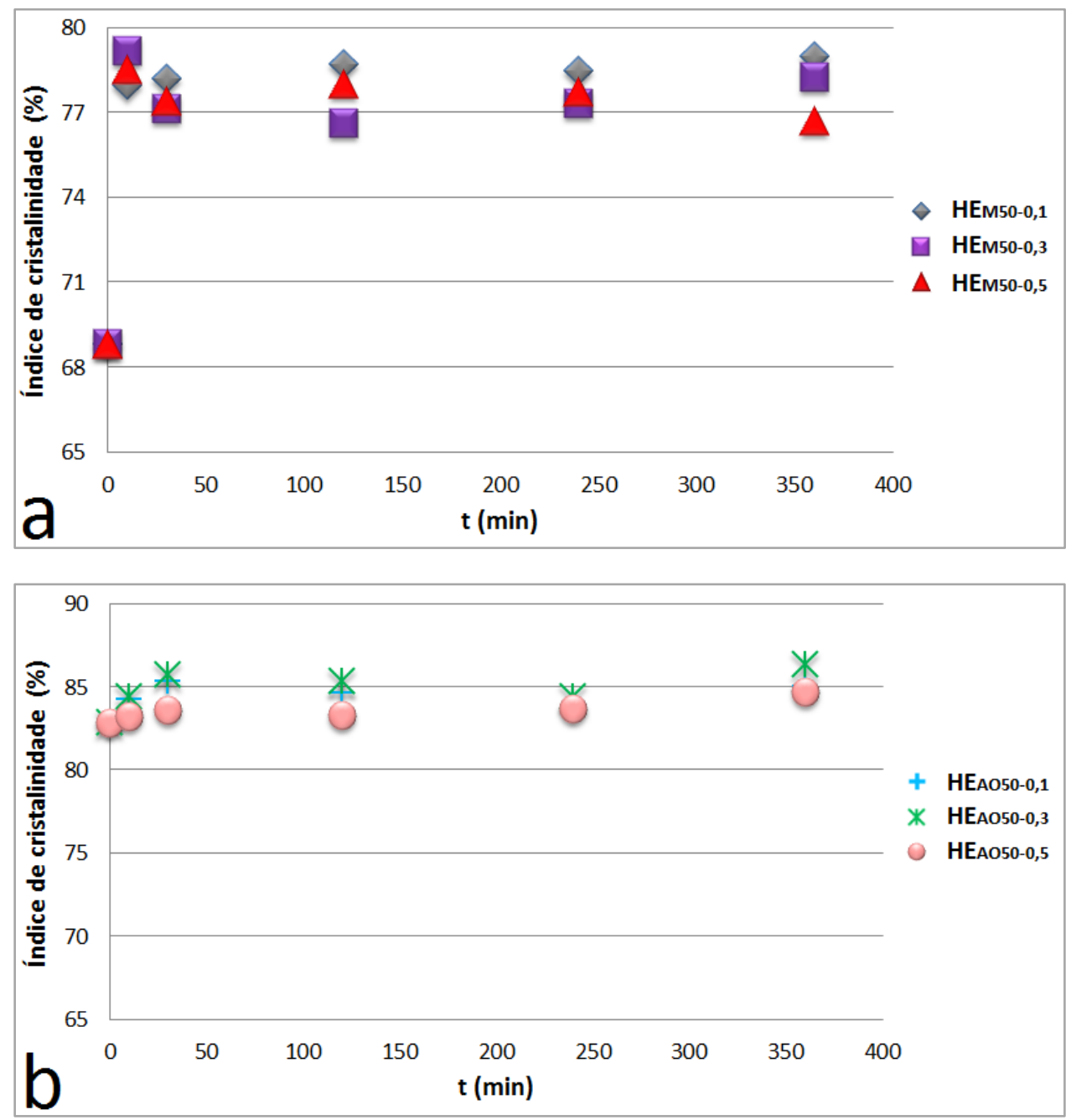

Figura 79 - Valores de índice de cristalinidade das polpas residuais das reações de hidrólise enzimática partindo de [a] polpa mercerizada e (b) polpa tratada com ácido oxálico 0,9 molL-1.

É possivel observar, comparando-se as Figura 79-a,b, uma diferença interessante entre os dois pré-tratamentos com relação ao comportamento do índice de cristalinidade da celulose suspensa no meio durante o curso da reação de hidrólise enzimática: no caso da polpa que passou pelo pré-tratamento de mercerização, que possui índice de cristalinidade igual a 69\%, inicialmente houve um aumento considerável no valor de $I_{c}$, indicando a hidrólise das regiões não cristalinas. Já quando a polpa tratada com ácido oxálico foi empregada como material de partida, não se observa grandes variações nos valores de $I_{c}$ das polpas residuais, apenas um aumento sutil nos minutos iniciais de reação, valores que se mantem aproximadamente constantes até $t=6$ h. 0 valor inicial de I. da polpa tratada com ácido oxálico [83\%] é muito alto e certamente prejudicou o acesso 
das enzimas para a hidrólise. Este fato se comprova quando se observa que, mesmo quando a polpa de partida mercerizada foi usada [ $\mathrm{I}_{\mathrm{c}}=69 \%$, o valor máximo de índice de cristalinidade das polpas residuais não atingem 80\%, e o valor mínimo se situa em torno de $77 \%$, o que é um indicativo da dificuldade do acesso das enzimas às regiões cristalinas, pois somente em torno de 3\% de domínios cristalinos foram destruídos.

Os gráficos a seguir mostram a variação das dimensões dos domínios cristalinos das polpas residuais isoladas (dimensão do plano 002), calculadas de acordo com a Equação 14, em função do tempo nas condições de reação utilizadas.
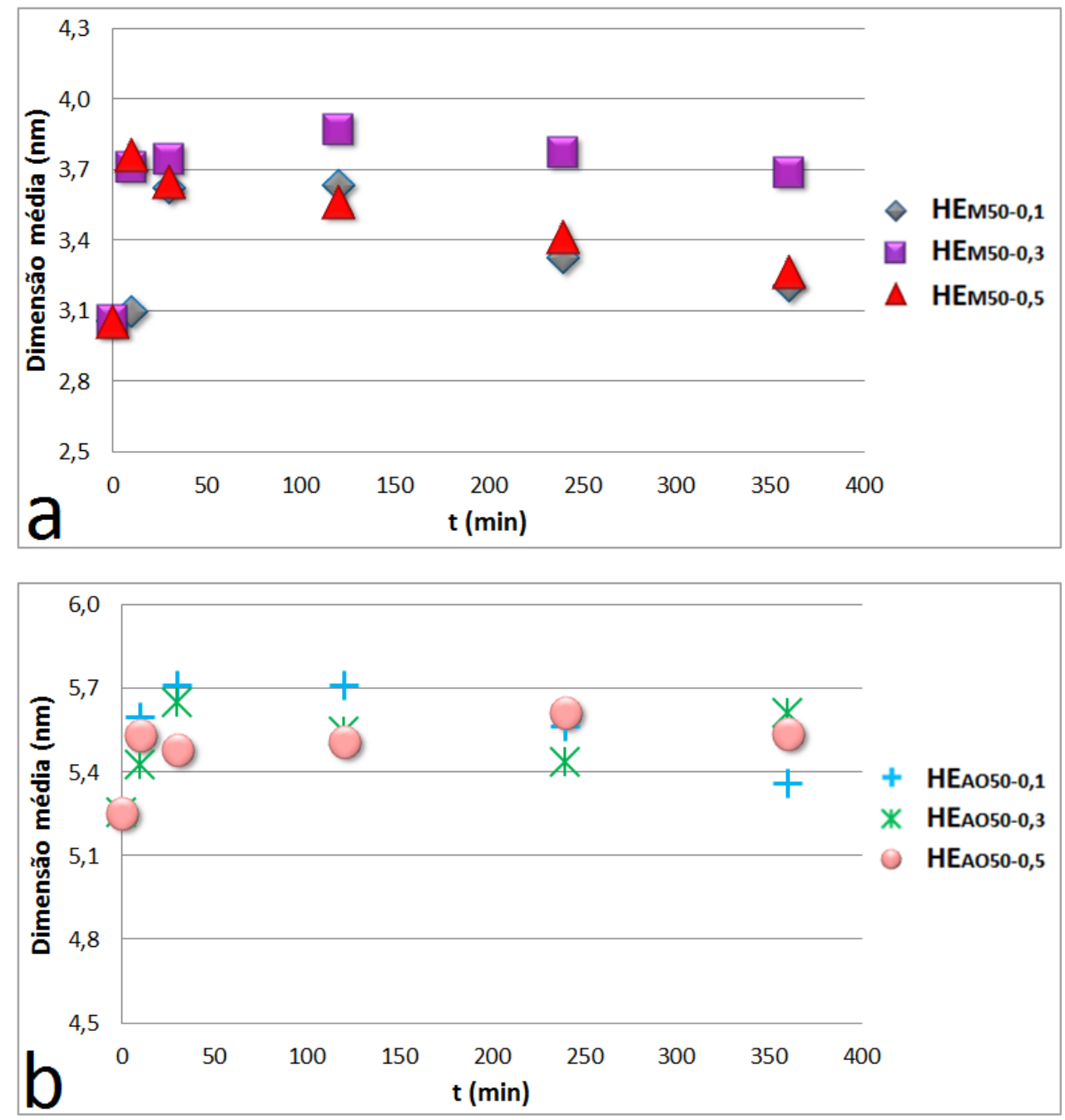

Figura 80 - Dimensão do plano 002 das polpas residuais em função do tempo da reação de hidrólise enzimatica partido de (a) polpa mercerizada e (b) polpa tratada com ácido oxálico $\left[T=50^{\circ} \mathrm{C}\right]$. 
Nos dois casos observa-se que a hidrólise enzimática inicia nas regiões não cristalinas e, como consequência, segmentos que inicialmente estavam em regiões não cristalinas, se rearranjam em empacotamentos mais ordenados, aumentando as dimensões médias dos domínios. Outra possibilidade corresponde à junção de domínios, em consequência da hidrólise das regiões não cristalinas que havia entre eles, o que também aumenta o tamanho médio dos domínios cristalinos. Para as reações que partiram de polpa mercerizada [Figura 80-a], na sequência, nota-se uma diminuição dos valores de dimensão de domínios cristalinos, ligada à próxima etapa, que é a hidrólise das regiões de maior cristalinidade, o que por sua vez leva a uma diminuição dos tamanhos médios dos cristalitos, refletidos na dimensão dos planos cristalográficos. No caso das reações que partiram da polpa tratada com ácido oxálico [Figura 80-b], este fenômeno também ocorre, embora em menor magnitude. Tanto o aumento inicial, reflexo da hidrólise dos domínios não cristalinos, quanto a diminuição subsequente, são mais sutis, fato que possivelmente está relacionado ao maior valor inicial de índice de cristalinidade da polpa tratada com ácido oxálico, o que corresponde a uma menor quantidade de regiões não cristalinas, de fácil acesso às enzimas, o que dificulta, consequentemente, o rearranjo em empacotamentos mais ordenados.

A Figura $\mathbf{8 1}$ mostra as micrografias das polpas residuais [não reagidas] obtidas a partir das reações de hidrólise enzimática realizadas partindo de polpa mercerizada ou tratada com ácido oxálico, para concentrações de enzima iguais a 0,1 e 0,5 mLg-1 . 

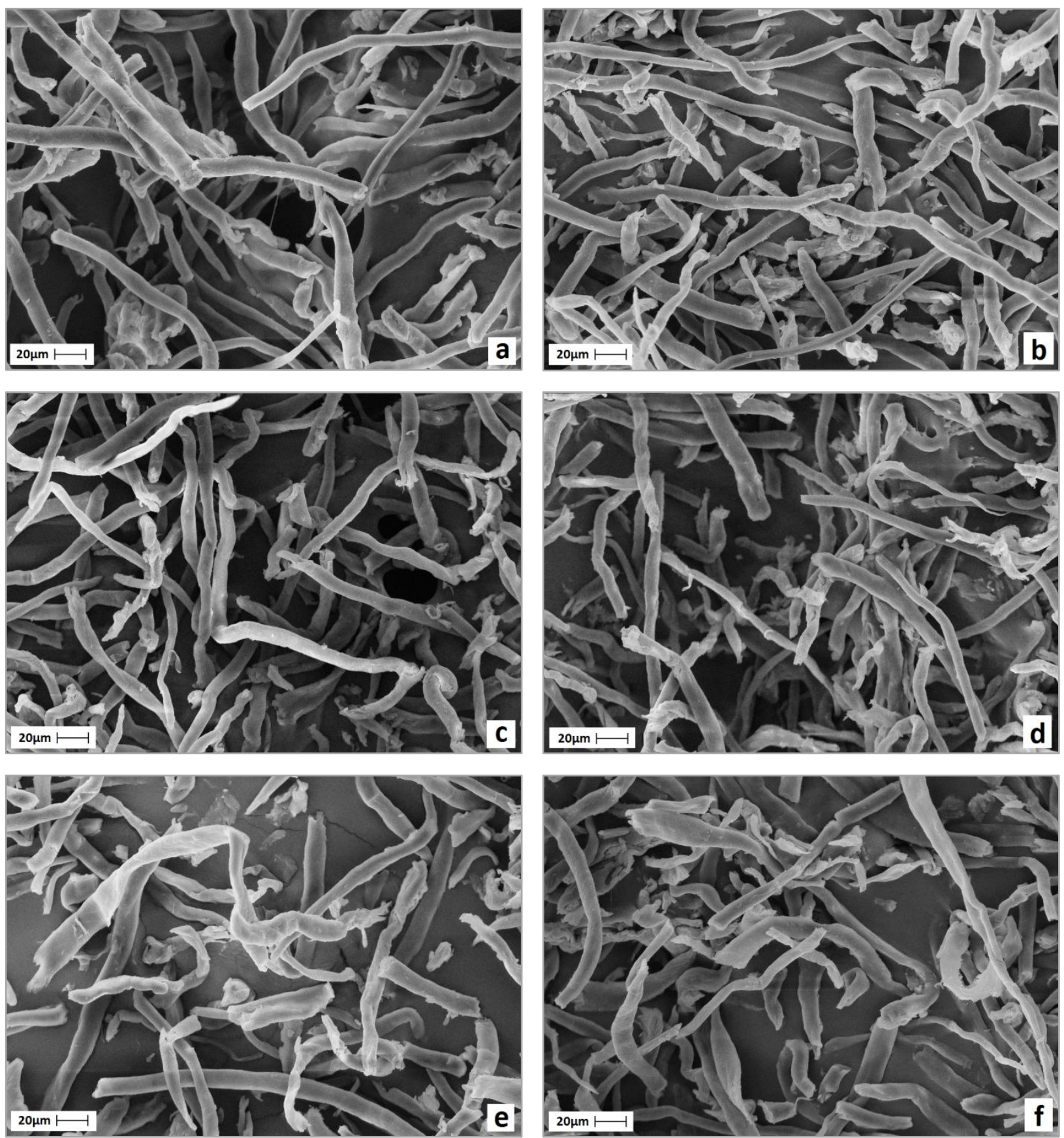

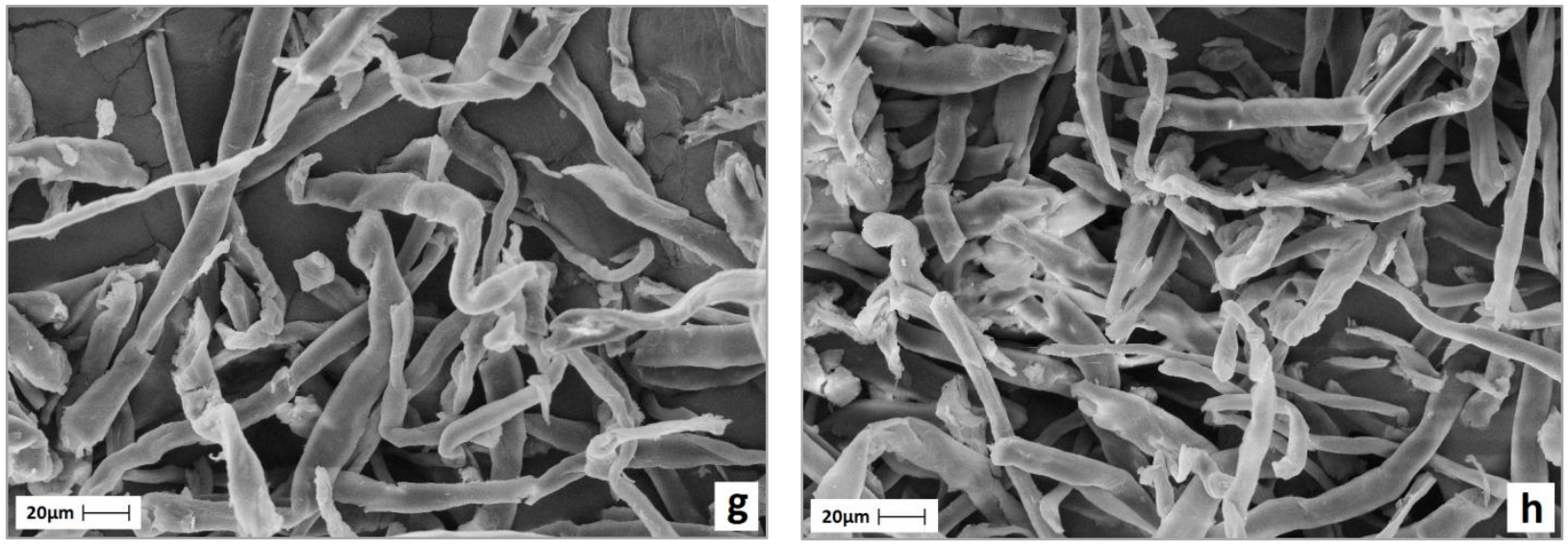

Figura 81 - Micrografias das polpas residuais das reações de hidrólise enzimática, a partir de polpa

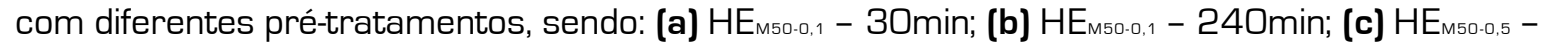

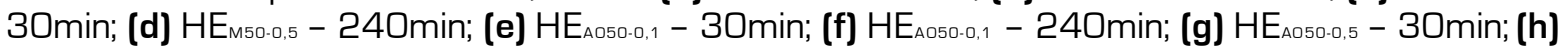
$\mathrm{HE}_{\triangle 050-0,5}-240 \mathrm{~min}$.

Ao comparar as micrografias das polpas residuais provenientes das reações de hidrólise catalisadas pelos ácidos sulfúrico e oxálico [Figura 28, Figura 40 e Figura 65] com aquelas provenientes das reações catalisadas por enzimas [Figura 81], observa-se que a catálise enzimática age de forma mais branda nas fibras, sendo que a estrutura morfológica fibrilar é pouco modificada, mesmo para tempos e concentrações de enzima maiores.

Apesar de não ser uma técnica definitiva para este fim, pelas imagens de microscopia há indícios de que as reações de hidrólise de celulose via catálise enzimática ocorrem preferencialmente a partir da superfície da fibra, já que, para tempos maiores, nota-se a presença de fibras menos espessas [Figura 81-d,f,h] do que as fibras de partida [Figura 77].

\subsubsection{Caracterização dos produtos gerados nas reações de hidrólise}

Ao contrário do que acontece nas reações de hidrólise de celulose catalisadas por ácido, nas reações por via enzimática não há a formação de produtos de decomposição. A alta especificidade das enzimas que compõe o complexo enzimático 
restringe a reação de hidrólise de celulose à formação de glicose, que permanece inerte no meio até o término da reação.

No caso do presente trabalho, como o material de partida corresponde à polpa de celulose, que é por definição constituída de celulose e hemiceluloses, e sendo o complexo enzimático também composto de hemicelulases além das endoglucanases, exoglucanases e $\beta$-glicosidases, é esperado que sejam detectados, além da glicose, também produtos de hidrólise das hemiceluloses, majoritariamente formadas por xilanas, no caso do sisal [MEGIATTO JÚNIOR et al., 2007].

A Figura 82 mostra os gráficos de concentração de glicose em função do tempo de reação para todas as reações avaliadas.

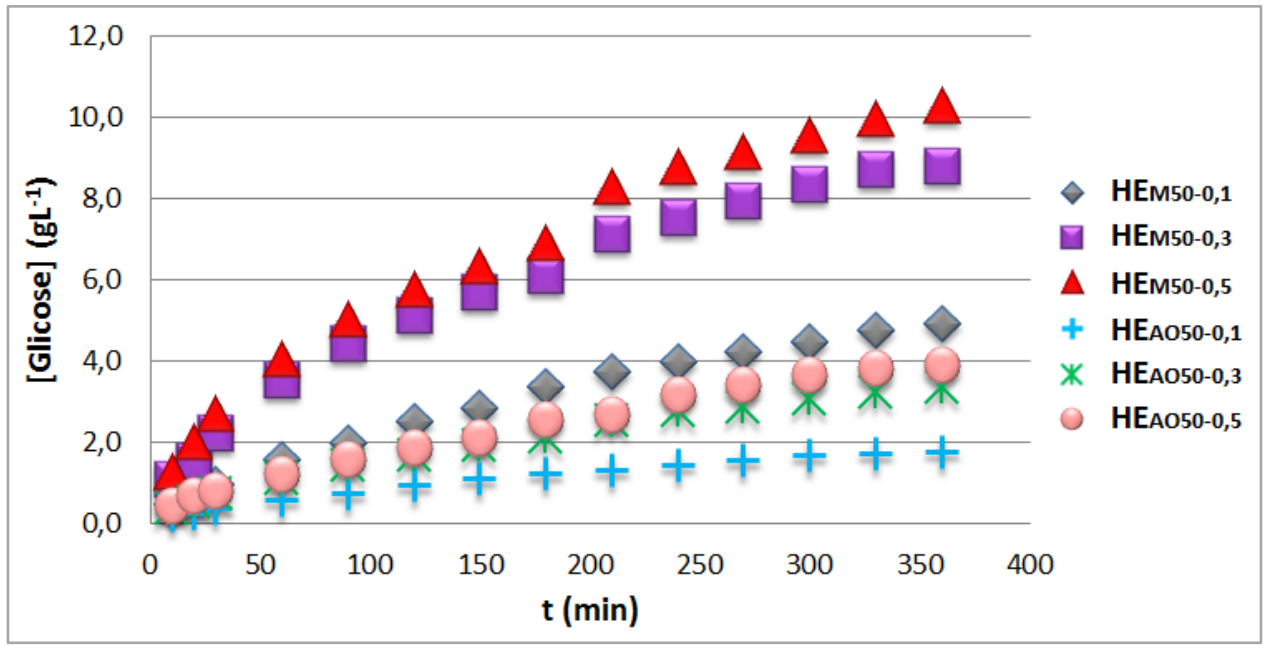

Figura 82 - Concentração de glicose no licor proveniente das reações de hidrólise enzimática, em todas as condições avaliadas.

Nota-se que tanto o pré-tratamento da mercerização quanto com o ácido oxálico permitiram a ação das enzimas sobre as fibras, havendo a produção de glicose ao longo de todo o processo. Entretanto, é nítida a maior eficiência do tratamento da mercerização para este fim, já que mesmo a menor concentração de enzima testada $\left[0,1 \mathrm{mLg}^{-1}\right]$ quando a reação partiu de polpa mercerizada $\left[\mathrm{HE}_{\mathrm{M50} 0,1}\right]$ foi capaz de produzir maior teor de glicose quando comparado com a reação que partiu da polpa tratada com ácido oxálico e maior 
concentração de enzima $\left[0,5 \mathrm{mLg}^{-1}, \mathrm{HE}_{\mathrm{A050}-0,5}\right]$. Este resultado deve ser decorrente da maior área de superfície e menor cristalinidade da polpa mercerizada, comparativamente a tratada com ácido, conforme já discutido. Ainda, a polpa tratada com ácido oxálico tem no material de partida domínios cristalinos cujas dimensões médias são cerca de 70\% superiores às da polpa mercerizada [Figura 80], o que também deve exercer influência no acesso das enzimas.

0 maior teor de glicose detectado [aproximadamente $10 \mathrm{gL}^{-1}$ ] foi obtido para a reação $\mathrm{HE}_{\mathrm{M50.0.5}}$. Este valor é próximo ao maior valor encontrado entre as todas as condições testadas por catálise ácida, e foi obtido pela reação com ácido sulfúrico 4,6 molL ${ }^{-1}$, partindo de polpa mercerizada, a $100^{\circ} \mathrm{C}$. Entre as grandes vantagens do uso da via enzimática, pode-se destacar neste caso, que o mesmo valor de concentração de glicose foi obtido no meio, mas a catálise enzimática ocorreu a uma temperatura 50\% menor que a reação realizada via catálise ácida. Este é um fator de grande importância quando o processo é realizado em escala industrial, já que acarreta em uma redução considerável de custos energéticos. Além deste fato, é muito importante salientar também que a via enzimática não gera subprodutos de decomposição que necessitam ser retirados do meio para posterior etapa de fermentação para a produção de etanol, como acontece largamente na via ácida, o que também gera custos ao final do processo.

Na Figura 83 constam os gráficos referentes à produção de xilose em função do tempo de reação. Xilose só foi detectada nas reações que partiram da polpa tratada com ácido oxálico, e não naquelas realizadas com polpa mercerizada. 


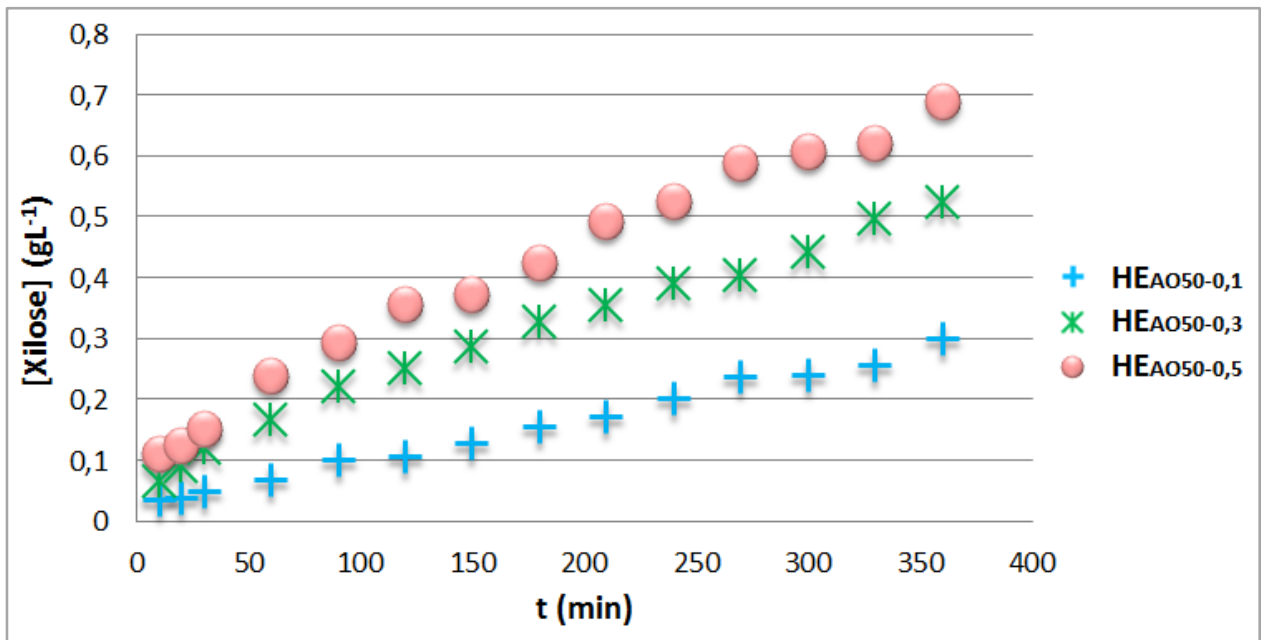

Figura 83 - Concentração de xilose no licor proveniente das reações de hidrólise enzimática que partiram de polpa tratada com ácido oxálico.

É possivel observar a correlação direta entre a concentração de enzima e a produção de xilose ao longo de todo o tempo de reação [Figura 83]. Esta correlação é linear e sempre crescente para as condições aqui testadas, sendo que a tendência, neste caso, é que a concentração atinja um valor máximo para tempos maiores de reação, permanecendo constante em seguida, uma vez que, ao contrário do que acontece por catálise ácida, não há aqui a decomposição da xilose a furfural e outros produtos de degradação, não havendo, portanto, razão para qualquer tipo de diminuição dos valores de concentração.

Conforme mencionado, os teores de $\alpha$-celulose obtidos para as duas polpas indicam que a polpa mercerizada contem somente $2 \%$ de hemiceluloses, o que corresponde a aproximadamente 1,4\% de xilose na polpa, considerando que 68\% das hemiceluloses do sisal corresponde a xilose. Portanto, mesmo se toda hemicelulose desta polpa for hidrolisada, uma pequena quantidade seria gerada. Se presente, a xilose estava abaixo do limite mínimo de detecção do equipamento [CLAE], não sendo possível de ser mensurada. É importante mencionar que, apesar do baixo teor de hemiceluloses na polpa mercerizada, em todas as reações envolvendo catálise ácida [ácidos sulfúrico e oxálico] foi possível detectar a presença de xilose, o que possivelmente ocorre pelo fato da hidrólise 
ácida ser um processo mais drástico e, portanto, mais eficaz no caso da hidrólise das hemiceluloses, presentes em menores concentrações com relação à celulose.

Arabinose foi detectada para todas as reações estudadas, mas em concentrações muito baixas, que não apresentaram um padrão de comportamento ao longo do tempo de reação. 0 maior teor de arabinose $\left[0,014 \mathrm{gL}^{-1}\right]$ foi encontrado para a reação $\mathrm{HE}_{\mathrm{A050} 0.5,5}$, em $\mathrm{t}=180$ min. A concentração máxima de arabinose detectada para hidrólise ácida foi de aproximadamente 0,19 $\mathrm{gL}^{-1}$ [ácido sulfúrico, $100^{\circ} \mathrm{C}, 4,6 \mathrm{molL}^{-1}$, Figura 48], ou seja, superior à detectada por hidrólise enzimática.

\subsubsection{RENDIMENTOS DA HIDRÓLISE ENZIMÁTICA DE POLPA DE SISAL}

Considerando o total de celulose pura presente na massa inicial [Tabela 1), é possível calcular o rendimento das reações de hidrólise ácida de polpa de sisal, mercerizada e tratada com ácido oxálico. Para isso, foi calculado o máximo que seria obtido de glicose se toda celulose fosse hidrolisada a glicose, com o uso das Equações 17 e 18.

Estes cálculos forneceram o valor de 21,6 $\mathrm{gL}^{-1}$ de glicose no licor, para o caso da polpa mercerizada, e 20,7 gL $^{-1}$ para o caso da polpa tratada com ácido oxálico, ou seja, potencialmente, se toda a celulose fosse convertida a glicose, estes valores deveriam ser detectados via CLAE.

Em posse destes valores, é possivel calcular, portanto, o rendimento das reações estudadas. Para isso, foram feitos cálculos tendo como base, os máximos valores de concentração de glicose obtidos para cada condição reacional. Para obter a porcentagem de celulose hidrolisada foi calculada a razão entre glicose detectada por CLAE, com a concentração máxima de glicose [que seria obtida se toda celulose fosse hidrolisada, 
tendo como produto a glicose], e este valor foi multiplicado por 100. A Equação 21 indica como foram feitos os cálculos.

$$
\% \text { de celulose hidrolisada }=\frac{[\text { glicose }]_{\text {detect }}}{[\text { glicose }]_{\text {máx. }}}
$$

A Tabela 15 resume os valores obtidos através dos cálculos acima descritos.

Tabela 15 - Valores de glicose máxima, glicose detectada e porcentagem de celulose hidrolisada a glicose para as reações $\mathrm{HE}_{\mathrm{\alpha} 0500,5}$ e HE $\mathrm{H}_{\mathrm{m} 00,5.5 .}$

\begin{tabular}{|c|c|c|}
\hline & $H E_{A 050.0,5}$ & $\mathrm{HE}_{\mathrm{M50-0,5}}$ \\
\hline Glicose máxima [gL-1] & 20,7 & 21,6 \\
\hline Tempo [h] & 6 & 6 \\
\hline Glicose detectada $\left[\mathrm{gL}^{-1}\right]$ & 3,9 & 10,3 \\
\hline$\%$ de cel. hidrolisada & 18,8 & 47,7 \\
\hline
\end{tabular}

Observa-se pela Tabela 15 que o rendimento da reação de hidrólise enzimática partindo da polpa mercerizada [aproximadamente 48\%] foi consideravelmente maior do que aquele obtido com o uso da polpa previamente tratada com ácido oxálico como material de partida [aproximadamente 19\%]. Este fato está, provavelmente, relacionado ao alto índice de cristalinidade da polpa que passou pelo tratamento com ácido oxálico [83\%], comparado com o respectivo valor apresentado pela polpa mercerizada [69\%], o que dificulta sobremaneira o acesso das enzimas entre as cadeias de celulose, para sua conversão a glicose. Ainda, pode-se concluir que o pré-tratamento da mercerização se mostrou mais eficiente no que diz respeito à eliminação de hemiceluloses da polpa, uma vez que o tratamento com o álcali, além de ser empregado em condições mais brandas de temperatura e tempo $\left[50^{\circ} \mathrm{C}, 3 \mathrm{~h}\right]$ quando comparado ao tratamento prévio com ácido oxálico $\left[100^{\circ} \mathrm{C}, 6 \mathrm{~h}\right.$ ], foi capaz de reduzir o teor de hemiceluloses de 12 para $2 \%$ [redução de mais de 80\%], enquanto o ácido oxálico reduziu para 6\% [redução de 50\%) apenas, 
conforme indicado pelos valores de $\alpha$-celulose determinados $198 \%$ para a polpa mercerizada e 94\% para a polpa tratada com ácido oxálico]. Adicionalmente, o tratamento com ácido oxálico leva a maior porcentagem de domínios cristalinos. 


\subsection{CONCLUSÕES PARCIAIS}

A mercerização facilita muito os processos de hidrólise ácida e enzimática de polpa de sisal. Além de eliminar hemiceluloses, que podem funcionar como barreira física para a penetração dos reagentes e aumentar o número de produtos de decomposição no meio, no caso da hidrólise ácida, a mercerização diminui a cristalinidade e a massa molar média da celulose presente na polpa.

O estudo das modificações de massa molar média e cristalinidade da polpa residual em função do tempo de hidrólise de polpa de celulose de sisal mostraram que é possível gerar, com o uso de ácido sulfúrico ou ácido oxálico como catalisador, celulose de alta cristalinidade e baixa massa molar média, que são características de celulose microcristalina. Concluiu-se que a partir reação $\mathrm{HAS}_{\text {м10оз, }}$, após 30 min, e da reação

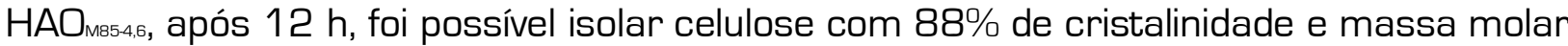
média em torno de $10000 \mathrm{gmol}^{-1}$.

Dentre todas as condições de hidrólise ácida da polpa de sisal estudadas, a que levou a melhores rendimentos [maior formação e menor decomposição de glicose] foi a

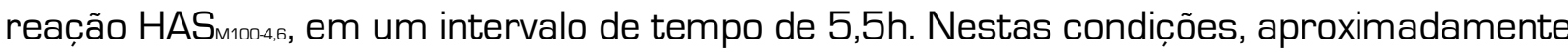
$40 \%$ da celulose foi hidrolisada sendo que destes, $28,4 \%$ não se decompuseram a HMF e derivados. Em contrapartida, para a reação realizada com ácido oxálico nesta mesma concentração, em um intervalo de tempo igual a 18h, aproximadamente 50\% da celulose foi hidrolisada sendo que 22,3\% não se decompuseram a HMF e derivados. Nota-se que, para que a reação com ácido sulfúrico atinja o valor máximo de glicose, são necessários 330 min enquanto que com o uso do ácido oxálico o tempo é de 18h para obter menor rendimento, o que significa maior custo energético. Entretanto, salienta-se a possibilidade 
de obtenção do ácido oxálico a partir de fontes renováveis, o que torna o processo, como um todo, interessante.

A partir de séries de reações com variação de temperatura foi possível calcular o valor da energia de ativação das reações ácido-catalisadas, para os dois ácidos avaliados, sulfúrico e oxálico, e os valores determinados experimentalmente foram de $126,9 \mathrm{kJmol}^{-1}$ e 185,9 kJmol', respectivamente. 0 valor calculado para $E_{a}$ da reação com ácido oxálico é maior do que aquele observado para a reação com ácido sulfúrico nas mesmas condições, o que pode ser justificado pelo menor grau de ionização do ácido oxálico, uma vez que, apesar das concentrações molares dos ácidos sulfúrico e oxálico serem as mesmas $\left[4,6\right.$ molL $\left.^{-1}\right]$, a concentração de íons $\mathrm{H}^{+}$, que são as espécies que de fato catalisam a reação de hidrólise ácida de celulose, são diferentes para cada ácido.

No que diz respeito às reações de hidrólise enzimática de polpa de sisal, comparou-se a eficiência de dois pré-tratamentos da polpa, ou seja, mercerização e tratamento com ácido oxálico 0,9 molL¹. Variou-se também a concentração do complexo enzimático, entre 0,1 e 0,5 mL por grama de polpa. Tanto a celulose mercerizada, quanto a tratada com ácido oxálico, apresentaram maiores valores de concentração de glicose quando a maior concentração do complexo enzimático foi usada. Ao comparar os teores de glicose formados nos dois casos, ficou evidente a melhor eficiência da mercerização como pré-tratamento das fibras, uma vez que, neste caso, o teor máximo de glicose encontrado no licor [aproximadamente $10 \mathrm{gL}^{-1}$ ] chega a ser até 2,5 vezes maior que o máximo teor de glicose encontrado quando a polpa tratada com ácido oxálico foi usada como material de partida [aproximadamente $3,9 \mathrm{gL}^{-1}$ ]. Este fato está provavelmente relacionado com o alto índice de cristalinidade da polpa tratada com ácido oxálico [83\%], o que significa que menores quantidades de cadeias de celulose estão facilmente acessíveis às enzimas, diminuindo, consequentemente, o teor de glicose formada. Esta 
dificuldade no acesso das enzimas às cadeias de celulose também é comprovado pelas variações nos valores de massa molar média viscosimétrica das polpas residuais das reações conduzidas via catálise enzimática, uma vez que as variações nos valores de $\mathrm{MM}_{\text {vis }}$ são mais nítidas quando a polpa mercerizada é usada, sendo que a massa molar média da polpa tratada com ácido oxálico tende a permanecer aproximadamente constante ao longo de toda a reação.

Estes resultados são de grande relevância no contexto em que este trabalho está inserido, pois se trata de um estudo que objetiva a aplicação das reações de hidrólise ácida e enzimática como via de produção simultânea de produtos químicos e materiais a partir do sisal, planta largamente produzida no Brasil e que atualmente gera produtos de baixo valor agregado. 


\section{Capítulo}

\section{HidRÓlise DE POLPA DE SISAL: APLICAC̣ÃO NA OBTENC̣ÃO DE FILMES "BIO-BASEADOS”}

\subsection{INTRODUĈ̣̃O}

Nos últimos anos, a previsão de diminuição dos recursos fósseis aliada ao aumento nos custos de extração, tem estimulado o interesse em alternativas renováveis e sustentáveis que possam substituir o petróleo como fonte de produtos químicos e materiais [GANDINI, 2008; KAMM, GRUBER e KAMM, 2006]. Dentro desta estratégia, polissacarídeos são excelentes candidatos por sua natureza renovável e reciclável, pelo caráter biodegradável, e pelo fato de representarem a fração mais abundante de toda biomassa existente. Celulose e quitina são os polissacarídeos naturais mais comuns, e vem sendo explorados para várias aplicações [FERNANDES et al., 2011]. 
A quitina é um polissacarídeo encontrado principalmente nas partes duras de crustáceos, moluscos e insetos. É o segundo biopolímero mais abundante encontrado na natureza depois da celulose, sendo um polímero linear composto por unidades

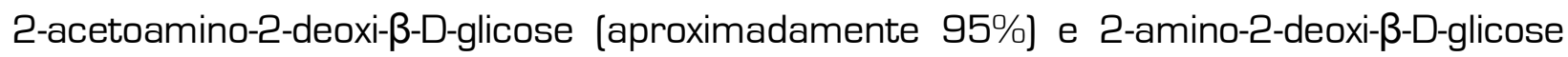
[aproximadamente 5\%] ligados através de ligações $\beta-[1 \rightarrow 4]$. Devido ao fato da quitina ser um produto natural, não deve ocorrer como composição única. Entende-se por isso, que ocorram variações estruturais. Tais variações incluem a dimensão das cadeias poliméricas, o conteúdo dos grupos amino e acetamido e a distribuição destes ao longo das cadeias. A quitina obtida a partir de diatomáceas [Thalassiosira fluviales e Cytlotella cryptica] é uma exceção, pois neste caso ocorrem exclusivamente as unidades 2-acetoamido-2-desoxi-D-glicopiranose (AGULLÓ et al., 2004). A estrutura química da quitina (Figura 84] é semelhante à da celulose [Figura 3], sendo que a principal diferença encontra-se no C2 do anel de glicopiranose, que contém o grupo hidroxila $[-\mathrm{OH}]$ na celulose e o grupo acetamida $\left[-\mathrm{NHCOCH}_{3}\right.$ ) na quitina [DELEZUK, 2009].

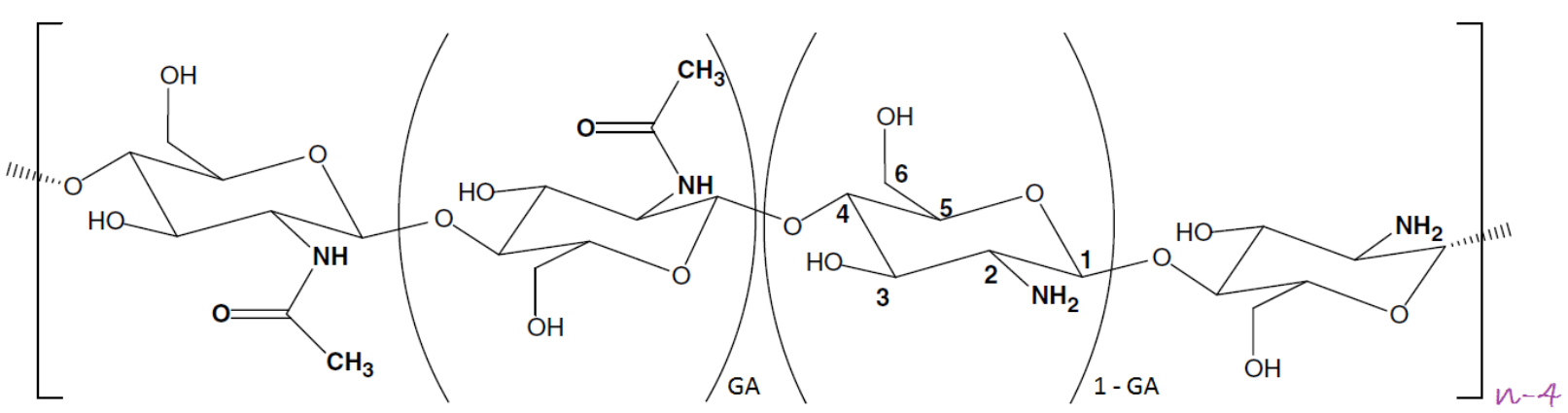

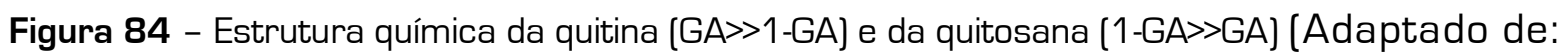

FERNANDES et al., 2011].

Uma das principais reações de derivatização da quitina é a hidrólise dos grupos acetamido, originando grupos amino, para gerar o polímero conhecido como quitosana [Figura 84]. As amidas em princípio podem hidrolisar tanto em condições ácidas quanto alcalinas, mas a hidrólise em meio ácido não é comumente empregada devido à susceptibilidade das ligações glicosídicas da quitina frente a hidrolise ácida. Geralmente a 
reação é realizada em solução aquosa alcalina, em um processo heterogêneo que apresenta como variáveis principais a concentração do álcali, a temperatura e o tempo de reação [DELEZUK, 2009]. O produto obtido da reação é denominado quitosana somente se a porcentagem média de grupos amino for igual ou superior a 40\% e, principalmente, se for solúvel em soluções aquosas diluídas de ácidos, como os ácidos clorídrico e acético [DELEZUK, 2009].

De maneira particular, há um crescente interesse no uso da quitosana como material de revestimento para várias aplicações, devido às suas excelentes propriedades de formação de filmes aliadas às atividades antimicrobiana e antifúngica [SHAHIDI et al., 1999; CANER, VERGANO e WILLES, 1998]. Além destas propriedades, filmes e revestimentos de quitosana vem sendo investigados por suas propriedades de barreira la habilidade de retardar a transferência de umidade e oxigênio, por exemplo], flexibilidade e potencial de melhorar as propriedades mecânicas e de resistência dos materiais finais aos quais a quitosana é associada [FERNANDES et al., 2011].

A principal aplicação da quitosana é como revestimento de alimentos, e está relacionada às suas propriedades filmogênicas, associadas ao fato de ser comestível e biodegradável, o que melhora a estabilidade nutricional e estende o tempo de armazenamento dos alimentos, limitando a contaminação [CANER e CANSIZ, 2007; HAN et al., 2004; SHAHIDI et al., 1999]. Entretanto, apesar das numerosas vantagens e propriedades únicas, os materiais derivados de quitosana, particularmente filmes, apresentam propriedades mecânicas pobres, o que dificulta seu uso para aplicações diversas [SHAHIDI et al., 1999]. Assim, a associação de outros elementos à quitosana com a finalidade de melhorar suas propriedades físico-químicas tem recebido atenção especial nos últimos anos, através da preparação de compósitos com fibras naturais ou blendas com outros polímeros. 
Nos últimos anos, uma quantidade considerável de estudos tratando do desenvolvimento de blendas de quitosana com vários polímeros [sintéticos e naturais] vem sendo publicada. Entre estes estudos destacam-se as associações da quitosana com álcool polivinílico [MUCHA e PAWLAK, 2005], poli-[vinilpirrolidona] [SAKURAI, MAEGAWA e TAKAHASHI, 2000], poli-[etilenoglicol] [KIUCHI, KAl e INOUE, 2008], poli-[óxido de etileno] (AMIJI, 1995], poli-[ácido lático] [SÉBASTIEN et al., 2006], amido [BOURTOOM e CHINNAN, 2008], colágeno [SIONKOWSKA et al., 2004] e poliamidas terciárias solúveis em água [FANG e GOH, 2000], além de compósitos com celulose e seus derivados (MORGADO et al., 2011; ALMEIDA et al., 2010; SHIH, SHIELD e TWU, 2009; LIMA, LAZARIN e AIROLDI, 2005; TWU et al., 2003]. Estes materiais apresentam, em geral, melhores propriedades mecânicas, bem como permeabilidade, biodegrabilidade, propriedades antifúngicas e antibacterianas, entre outras, estendendo a utilização da quitosana para novos produtos de maior valor agregado, como por exemplo, em aplicações farmacêuticas e em cosméticos [FERNANDES et al., 2011].

\subsection{FILMES DE CELULOSE E QUITOSANA}

Entre as possibilidades mencionadas acima de associação de diversos polímeros com a quitosana para a produção de novos materiais, maior destaque pode ser dado à celulose. Combinações de celulose-quitosana são de interesse particular devido às semelhanças estruturais existentes entre as cadeias, resultando em materiais compósitos compativeis que combinam as propriedades físico-químicas da quitosana com as excelentes propriedades mecânicas da celulose [PHISALAPHONG e JATUPAIBOON, 2008; YIN et al., 2006; WU et al., 2004], além da alta disponibilidade destes polissacarídeos. Aplicações práticas de compósitos de celulose/quitosana envolvem seu processamento em filmes, que normalmente apresentam alta resistência, biocompatibilidade, biodegrabilidade e hidrofilia. 
Nos últimos anos, estudos foram conduzidos no desenvolvimento de blendas de quitosana/celulose. Shih e colaboradores [SHIH, SHIEH e TWU, 2009] usaram N-óxido de N-metilmorfolina como solvente direto da celulose, mencionando que este seria um solvente bastante promissor, tanto para a celulose quanto para a quitosana. Wu e colaboradores [WU et al., 2004] prepararam blendas de quitosana e celulose a partir de soluções com ácido trifluoracético, indicando que a quitosana pode melhorar as propriedades da celulose, tais como suas propriedades de barreira e mecânicas. Almeida e colaboradores (ALMEIDA et al., 2010) desenvolveram com sucesso filmes de quitosana/celulose pela dissolução no sistema $\mathrm{NaOH}$ /tiouréia, que levou à despolimerização dos polissacarídeos e a alguma desacetilação da quitosana, sem a perda de suas propriedades filmogênicas.

Outra possibilidade de associação entre celulose e quitosana é a introdução direta das fibras da celulose como reforço à matriz de quitosana, apoiando-se na facilidade de dissolução da quitosana em sistemas de ácidos diluídos, como por exemplo o ácido acético. A presença de ligações hidrogênio intra e intermoleculares [Figuras 3 e 4] torna a celulose um polímero relativamente estável e proporciona às suas cadeias uma alta rigidez axial [KROON-BATENBURG, KROON e NORTHOLT, 1986], o que é uma propriedade altamente desejável quando um material é usado como reforço em compósitos. Esta propriedade pode ser melhorada através da quebra da estrutura hierárquica da planta em nanofibras individuais de alta cristalinidade, portanto de menor teor de regiões não cristalinas [EICHHORN et al., 2010]. Neste sentido, destacam-se estudos envolvendo whiskers [ou nanocristais] de celulose obtidos por hidrólise ácida, como reforço da matriz de quitosana [LI, ZHOU e ZHANG, 2009].

Dessa maneira, torna-se particularmente interessante a avaliação do material não hidrolisado durante as etapas de hidrólise ácida e enzimática de celulose para a 
preparação de materiais [filmes] em que a quitosana é combinada com celulose. A catálise ácida, descrita na sequência, corresponde a método bem estabelecido de produção de nanocristais de celulose, enquanto a via enzimática não é normalmente aplicada com esta finalidade.

No presente trabalho, whiskers de celulose de sisal foram preparados por hidrólise ácida, e a potencialidade da via enzimática também foi avaliada para este fim. material proveniente destes processos foi aplicado em matriz de quitosana para a produção de filmes, e suas propriedades foram avaliadas.

\subsection{HIDRÓLISE ÁCIDA DE POLPA CELULÓSICA PARA A PRODUÇÃO DE NANOCRISTAIS}

Nanocristais de celulose [também chamados whiskers de celulose] tem atraído grande interesse nos últimos anos devido às suas notáveis propriedades mecânicas e dimensões na ordem de nanômetros, o que resulta em materiais com razões de aspecto muito altas, sendo que este parâmetro varia de acordo com a fonte lignocelulósica. Estas características tornam as nanopartículas de celulose ideais para serem usadas como reforço em nanocompósitos, melhorando sobremaneira suas propriedades mecânicas [RAMIRES e DUFRESNE, 2011].

Suspensões aquosas estáveis de nanopartículas de celulose podem ser preparadas através de hidrólise ácida de biomassa. Estas suspensões apresentam um comportamento coloidal, e podem ser usadas para processar nanocompósitos usando um polímero como matriz. Os nanocompósitos constituem uma classe relativamente nova de compósitos e, devido ao efeito das dimensões nanométricas, estes materiais possuem excelentes propriedades quando comparados com seus microcompósitos análogos [SAMIR, ALLOIN e DUFRESNE, 2005]. 
Como a maioria dos polímeros usados para preparar nanocompósitos corresponde a materiais sintéticos, sua processabilidade, biocompatibilidade e biodegradabilidade são muito mais limitadas do que aqueles obtidos de fontes naturais. Comparando-se os estudos no campo de micro e nanocompósitos baseados em materiais sintéticos e não biodegradáveis, poucos são aqueles focados na área de bionanocompósitos. Outra vantagem do uso de reforços de fontes naturais é sua disponibilidade e consequente menor custo quando comparados com os sintéticos.

Ranby [1951] e Battista [1956] foram os primeiros que produziram, com sucesso, suspensões coloidais estáveis de celulose cristalina por hidrólise ácida, processo que foi recentemente otimizado (HAMAD e HU 2010; BONDERSON, MATHEW e OKSMAN, 2006]. A extração [ou isolamento] das regiões cristalinas da celulose em nanocristais em forma de haste é um processo simples baseado em uma reação de hidrólise ácida. A biomassa primeiramente passa por purificação e branqueamento, e após a remoção de constituintes não-celulósicos, principalmente lignina e hemiceluloses, o material branqueado passa por reação de hidrólise com ácido sob condições controladas. As regiões não cristalinas atuam como defeitos estruturais, sendo responsáveis pela clivagem na direção transversal das microfibrilas em monocristais de menor dimensão [MARCHESSAULT, MOREHEAD e KOCH, 1961; BATTISTA et al., 1956]. Esta transformação consiste na quebra das regiões não cristalinas vizinhas às microfibrilas de celulose, deixando os segmentos microcristalinos intactos. Esta possibilidade é atribuída à cinética mais rápida de hidrólise das regiões não cristalinas, comparadas às cristalinas. íon hidrônio penetra nas regiões não cristalinas do material celulósico, promovendo a clivagem hidrolítica das ligações glicosídicas, que libera os cristalitos individuais. A suspensão resultante é subsequentemente diluída com água e lavada por sucessivas centrifugações. Na sequência é feita diálise com o uso de membrana adequada visando à remoção do ácido residual. Algumas vezes uma etapa de sonicação é necessária para 
desintegrar possíveis agregados e dispersar completamente os whiskers. Este procedimento é geral, e deve ser adaptado de acordo com a natureza do substrato [RAMIRES e DUFRESNE, 2011; SAMIR, ALLOIN e DUFRESNE, 2005].

O primeiro estudo envolvendo a análise do efeito de whiskers de celulose como reforço em materiais nanocompósitos foi realizado por Favier e colaboradores [FAVIER et al., 1995a; FAVIER et al., 1995b]. Um notável aumento no módulo de armazenamento pode ser observado quando o copolímero de estireno e acrilato de butila [poli[S-co-BuA]] foi reforçado com whiskers de tunicina [celulose bacteriana], mesmo em concentrações baixas.

excelente efeito de reforço dos whiskers de celulose em nanocompósitos é atribuído ao fenômeno de percolação [FAVIER et al., 1995a; FAVIER et al., 1995b]. Acima do chamado "limiar de percolação", as nanopartículas de celulose se conectam, formando uma estrutura tridimensional contínua ao longo do material. A formação desta rede de celulose é resultado das fortes interações entre os whiskers, como ligações hidrogênio [FAVIER et al., 1997]. Este fenômeno de percolação é similar às boas propriedades mecânicas de uma folha de papel, resultantes das forças de hidrogênio na rede de fibras, e explica o efeito de reforço e a estabilidade térmica dos materiais compósitos produzidos por evaporação ["casting"].

A dimensão nanométrica das fibras também permite que a transparência dos filmes seja mantida, o que não acontece quando se usa fibras de celulose em maiores dimensões [FERNANDES et al., 2011]. A incorporação de micro e nanofibras de celulose em diversas matrizes poliméricas, incluindo quitosana, produz materiais com propriedades mecânicas, térmicas, de barreira e de transparência superiores (FUKUZUMI et al., 2009; KIM et al., 2009; NORDQVIST, IDERMARK e HEDENQVIST, 2007]. A busca por novos filmes, provenientes de fonte renovável, para aplicações em 
dispositivos eletrônicos e embalagens é um campo de pesquisa relativamente recente e bastante promissor [NOGl et al., 2009].

No presente trabalho, filmes de quitosana foram associados a fibras de celulose [em escala micro e nanométrica], obtidas a partir de hidrólise ácida e enzimática. Até o presente momento, trabalhos que relacionam a hidrólise de celulose por via enzimática, com a produção de nanocristais, não foram extensivamente relatados [HAYASHI, KONDO e ISHIHARA, 2005], e esta etapa do presente estudo correspondeu a uma exploração inicial desta possibilidade para as fibras provenientes do sisal. Os filmes formados pela associação de celulose e quitosana correspondem a um material bastante promissor por suas características de biodegradabilidade, e por exibir boas propriedades de processamento em filmes (SOUZA et al., 2010; PORTES et al., 2009; BORDENAVE et al., 2007]. Esta etapa do trabalho é parte do projeto de Doutorado Sanduíche no Exterior [novembro/2009 - abril/2010] na Unité Sciences du Bois et des Biopolymères Université de Bordeaux /[França], sob orientação da Profa. Dra. Véronique Coma. 


\subsection{EXPERIMENTAL}

\subsection{MATERIAIS}

A polpa utilizada em todas as etapas do trabalho foi a de sisal, gentilmente cedida pela empresa Lwarcell [Lençóis Paulista, SP) onde a fibra lignocelulósica passou pelo processo de polpação [ou deslignificação] do tipo kraft e sequência de branqueamento do tipo ECF [Elemental Chlorine Free]. 0 teor de lignina Klason foi determinado com o uso da norma TAPPI T222-om02, e a presença de lignina insolúvel não foi detectada. Todas as amostras de polpa de celulose foram trituradas em moinho Marconi [MA048] e secas em estufa de circulação a $105^{\circ} \mathrm{C}$ por $4 \mathrm{~h}$, antes de serem utilizadas.

Como reagentes e solventes foram utilizados:

- Quitosana de baixa massa molecular [Sigma-Aldrich];

- Ácido acético glacial [Qhemis], usado na solubilização da quitosana;

- Citrato de sódio e ácido cítrico [Qhemis] para a preparação de tampão citrato, usado nas reações de hidrólise enzimática;

- Complexo enzimático "Accellerase 1500" [Genencor], usado nas reações de hidrólise enzimática;

- Ácido sulfúrico PA 95-98\% [Qhemis], para a preparação dos nanocristais de celulose;

- Membrana de diálise (tubo de diálise) de celulose benzoilada, com $32 \mathrm{~mm}$ de largura, e massa molecular de corte (MWCO) de $2000 \mathrm{gmol}^{-1}$ [Sigma-Aldrich].

complexo enzimático "Accellerase 1500" contém, principalmente, exoglucanases, endoglucanases, hemicelulases e $\beta$-glicosidases. 


\subsubsection{MÉTODOS}

\subsubsection{Preparação de filmes de quitosana}

Filmes de quitosana foram obtidos por evaporação ["casting"] a partir de uma solução de quitosana/ácido acético glacial/água [2:2:96 wt\%]. Para preparar cada filme, $41 \mathrm{~g}$ da solução de quitosana previamente degasada foram mantidos em repouso em placa de polipropileno quadrada $120 \times 120 \mathrm{~mm}$, a $35^{\circ} \mathrm{C}$, em estufa de circulação.

\subsubsection{Hidrólise ácida de polpa celulósica para obtenção de nanocristais}

Nanocristais de celulose foram obtidos por método descrito anteriormente [RAMIRES e DUFRESNE, 2011; SAMIR, ALLOIN e DUFRESNE, 2005; FAVIER et al., 1997; FAVIER et al., 1995a; FAVIER et al., 1995b]. Para a polpa de sisal, este método consiste em suspender a polpa celulósica previamente tratada com solução de $\mathrm{NaOH} 4 \%$ [wt\%], em $\mathrm{H}_{2} \mathrm{SO}_{4}$ 65\% (wt\%), a $50^{\circ} \mathrm{C}$ por 45 minutos. Após consecutivas centrifugações e lavagens com água, os nanocristais formam uma suspensão coloidal estável, e esta suspensão é mantida em membrana de diálise até que atinja $\mathrm{pH}$ igual ao da água.

Após adição de gotas de triclorometano $\left[\mathrm{CHCl}_{3}\right]$, a suspensão de água/nanocristais de celulose foi armazenada sob refrigeração.

\subsubsection{Hidrólise enzimática de polpa celulósica para a obtenção de micro e} nanofibras

A viabilidade da catálise enzimática para a obtenção de micro e nanocelulose foi avaliada, com o propósito de aplicar o material obtido (polpa residual não convertida a açúcares durante o processo] em filmes de quitosana, e comparar a propriedade destes filmes com as propriedades correspondentes àqueles associados a nanocristais de celulose obtidos por hidrólise ácida. 
Para isso, as reações foram conduzidas em frascos de $250 \mathrm{~mL}$ [Shott], em tampão citrato 0,01 $\mathrm{molL}^{-1}[\mathrm{pH}=5]$. Frasco, tampão e polpa celulósica foram previamente esterilizados em autoclave $\left[121^{\circ} \mathrm{C}, 20 \mathrm{~min}\right]$. Após resfriamento, adicionou-se o complexo enzimático ao sistema [0,5 mL de enzimas por grama de polpa celulósica], que foi mantido em uma câmara incubadora com agitação orbital (Marconi MA410) durante um intervalo de $100 \mathrm{~h}, \mathrm{a} 50^{\circ} \mathrm{C}$.

\subsubsection{Preparação de filmes de quitosana associados a micro/nanocelulose}

Filmes de quitosana e micro/nanocelulose foram obtidos a partir de suspensões de diferentes concentrações em massa de celulose/quitosana. Depois de depositadas, as suspensões foram mantidas em repouso em placa de polipropileno quadrada 120x120mm, a $35^{\circ} \mathrm{C}$, em estufa de circulação, para a formação dos filmes.

A fim de avaliar as diferenças nas propriedades de filmes de quitosana reforçados com fibras de celulose com dimensões nas escalas micrométrica e nanométrica, os biocompósitos foram gerados pela adição de [i] suspensão aquosa de microfibras de celulose [polpa sem tratamento e mercerizada], [ii] suspensão aquosa de nanocristais de celulose obtidos por hidrólise ácida ou [iii] suspensão aquosa de micro/nanofibras de celulose obtidas por hidrólise enzimática, à solução de quitosana. A suspensão de celulose/quitosana foi mantida sob agitação por 30 min, em banho de ultrassom, para eliminar possíveis aglomerações, principalmente no caso dos nanocristais de celulose. Ao final do processo, os biocompósitos foram obtidos com as seguintes concentrações: 2,5, 7,5 e 15,0\% em massa de celulose, com relação à massa de quitosana. As propriedades dos filmes foram comparadas com aquelas correspondentes aos filmes de 100\% de quitosana. 


\subsubsection{Caracterização dos filmes de quitosana/celulose}

Os ensaios mecânicos de tração foram realizados em um equipamento EMIC DL3000 [EMBRAPA - São Carlos]. Os ensaios foram realizados com velocidade de 10 mm.min¹, com célula de carga de 50 kgf. Os corpos de prova foram produzidos com as dimensões de 10 × $100 \mathrm{~mm}$. A morfologia dos filmes foi avaliada a partir de um microscópio eletrônico de varredura de emissão de campo [FEG-MEV] Magellan 400L [FEl], a 5kV, em modo de imersão. 


\subsection{RESULTADOS E DISCUSSÃO}

Filmes de quitosana/celulose foram obtidos pela associação de solução de quitosana com suspensões aquosas de polpa de sisal sem tratamento e mercerizada [3h, $50^{\circ} \mathrm{C}$ ], e de suspensões aquosas de polpa de sisal obtidas por hidrólise ácida [nanocristais] e por hidrólise enzimática [micro/nanocelulose], para produzir filmes com diferentes proporções [\% em massa] de quitosana e celulose, como descrito na parte experimental [seção 3.2.2.4].

Na Tabela 15 constam os códigos usados para denominar os diferentes filmes produzidos, bem como a concentração final de cada um deles. 
Tabela 15 - Códigos usados para denominar os filmes de quitosana/celulose, e suas respectivas porcentagens [em massa].

\begin{tabular}{|c|c|c|c|}
\hline Amostra & Código & $\%$ de quitosana & $\%$ de celulose \\
\hline Quitosana 100\% & Q100 & 100 & 0,0 \\
\hline $\begin{array}{l}\text { Quitosana +polpa } \\
\text { sem tratamento }\end{array}$ & QPST2,5 & 97,5 & 2,5 \\
\hline $\begin{array}{l}\text { Quitosana + polpa } \\
\text { sem tratamento }\end{array}$ & QPST7,5 & 92,5 & 7,5 \\
\hline $\begin{array}{l}\text { Quitosana +polpa } \\
\text { sem tratamento }\end{array}$ & QPST15 & 85 & 15,0 \\
\hline $\begin{array}{l}\text { Quitosana + polpa } \\
\text { mercerizada }\end{array}$ & QPM2,5 & 97,5 & 2,5 \\
\hline $\begin{array}{l}\text { Quitosana + polpa } \\
\text { mercerizada }\end{array}$ & QPM7,5 & 92,5 & 7,5 \\
\hline $\begin{array}{l}\text { Quitosana + polpa } \\
\text { mercerizada }\end{array}$ & QPM15 & 85 & 15,0 \\
\hline $\begin{array}{c}\text { Quitosana + } \\
\text { nanocristais de } \\
\text { celulose }\end{array}$ & QNC2,5 & 97,5 & 2,5 \\
\hline $\begin{array}{l}\text { Quitosana + } \\
\text { nanocristais de } \\
\text { celulose }\end{array}$ & QNC7,5 & 92,5 & 7,5 \\
\hline $\begin{array}{c}\text { Quitosana + } \\
\text { nanocristais de } \\
\text { celulose }\end{array}$ & QNC15 & 85 & 15,0 \\
\hline $\begin{array}{c}\text { Quitosana + } \\
\text { micro/nanocelulose } \\
\text { (hidrólise enzimática] }\end{array}$ & QHE2,5 & 97,5 & 2,5 \\
\hline $\begin{array}{c}\text { Quitosana + } \\
\text { micro/nanocelulose } \\
\text { (hidrólise enzimática) }\end{array}$ & QHE7,5 & 92,5 & 7,5 \\
\hline $\begin{array}{c}\text { Quitosana + } \\
\text { micro/nanocelulose } \\
\text { (hidrólise enzimática) }\end{array}$ & QHE15 & 85 & 15,0 \\
\hline
\end{tabular}




\subsubsection{CARACTERIZACEÃO DOS FILMES}

\subsubsection{Ensaios mecânicos de tração}

A Figura 85 mostra os resultados de módulo de elasticidade, tensão e deformação na ruptura, obtidos pelos ensaios de tração. É importante salientar que para uma determinada condição (tratamento da polpa, razão celulose/quitosana], amostras com razoável heterogeneidade foram obtidas. Dessa maneira, para cada conjunto de filmes foram escolhidas duplicatas, a partir de amostras que apresentaram maior homogeneidade entre si. Os resultados mostrados [média desta duplicata] devem, portanto, serem considerados como indicadores destas propriedades mecânicas, ou seja, indicadores do potencial que cada filme tem com relação à solicitação mecânica de tração. 

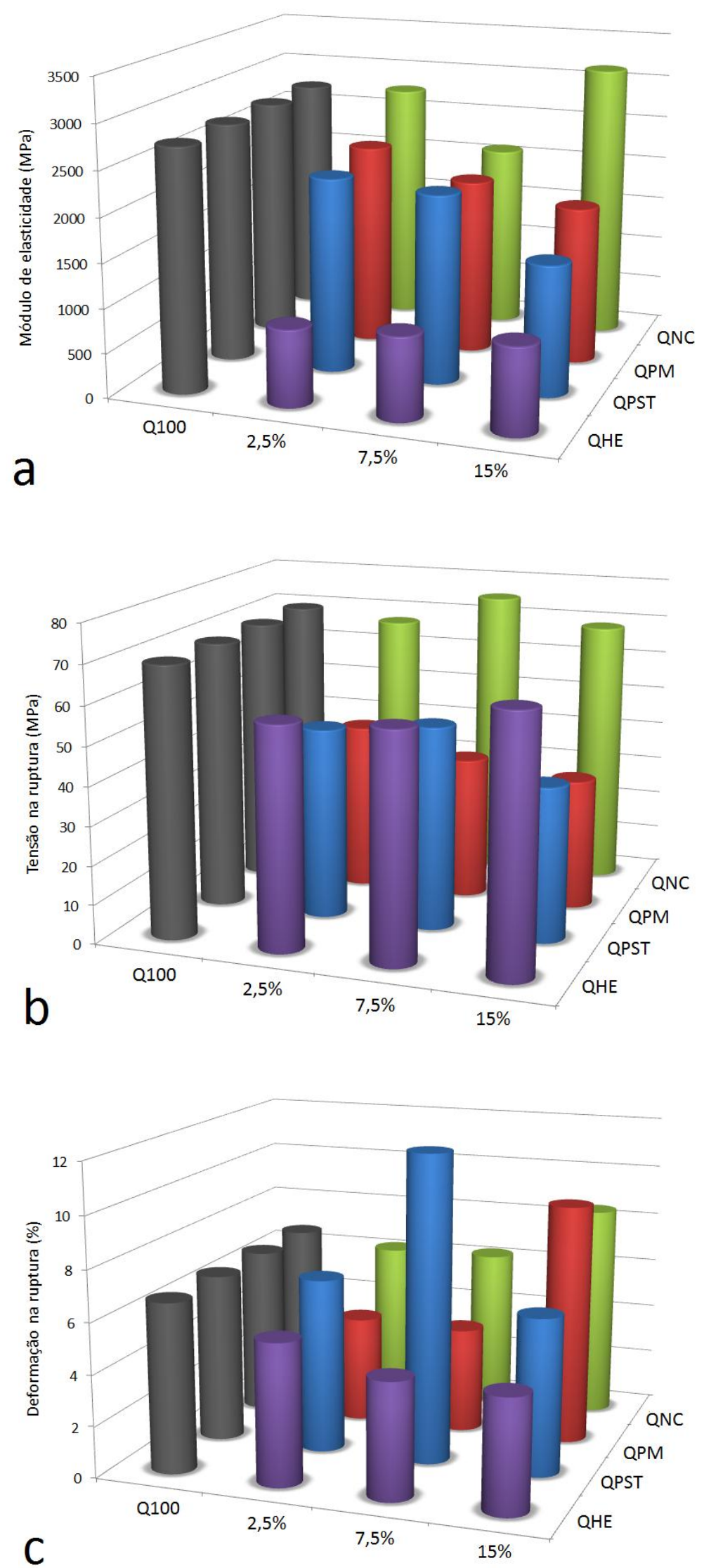

Figura 85 - Propriedades mecânicas sob tração dos filmes obtidos. Erros variando entre [a] 0,20 e $8,40 \%$, [b] 0,10 e $14,40 \%$ e [c] 0,70 e 12,20\%. 
No geral, a adição de polpa celulósica à matriz de quitosana levou a filmes que, quando submetidos à tração, apresentaram módulo, tensão e deformação na ruptura inferiores ou no mesmo patamar do filme Q100 [100\% de quitosana] (Figura 85). Este conjunto de resultados mostra diferentes comportamentos em função da razão quitosana/celulose, de acordo com o tratamento realizado na polpa celulósica. Quando a polpa sem tratamento foi usada [QPST], observa-se que o módulo de elasticidade diminui consideravelmente conforme se aumenta o teor de polpa, o que também acontece quando a polpa mercerizada [QPM] é usada. Comparando os processos de hidrólise ácida e enzimática, fica evidente a maior eficiência da hidrólise ácida na produção de estruturas que, quando combinadas, resistem mais à solicitação mecânica, uma vez que todas as concentrações testadas de polpa que passou por hidrólise enzimática [QHE] apresentaram resultados de módulo de elasticidade consideravelmente menores do que aqueles correspondentes ao filme de quitosana (Q100), enquanto os filmes produzidos com nanocristais de celulose obtidos por hidrólise ácida corresponderam ao melhor conjunto de resultados, com valores de módulo de elasticidade próximos ou superiores à Q100 [QNC2,5 e QNC15, Figura 85-a]. No que diz respeito à tensão na ruptura (Figura 85-b], comparando-se os diferentes tratamentos, nota-se que as hidrólises ácida e enzimática corresponderam a um efeito positivo sobre a ação da polpa na matriz de quitosana, uma vez que, comparativamente às polpas sem tratamento e mercerizada, possibilitaram a produção de material com melhores propriedades mecânicas. Ainda, os melhores resultados obtidos [QHE15 e QNC7,5] são uma indicação de que baixas concentrações de celulose podem representar "defeitos" na continuidade da matriz de quitosana, resultando em materiais com propriedades mecânicas pobres. Os resultados de deformação na ruptura indicaram valores menores para os filmes preparados com a polpa residual da reação de hidrólise enzimática, sendo que há a tendência de diminuição com o aumento da concentração de polpa. Há um destaque para o filme QPST7,5, que 
apresentou maior valor de deformação na ruptura [aproximadamente 10\%]. Os filmes gerados a partir de polpa mercerizada e nanocristais de celulose obtidos por hidrólise ácida apresentaram maiores valores de deformação na ruptura quando 15\% de celulose foram adicionados.

Butler e colaboradores [BUTLER et al., 1996] prepararam filmes de quitosana com a adição de glicerol em duas concentrações $[0,25$ e $0,50 \mathrm{~mL} / \mathrm{g}$ de quitosana], e obtiveram valores de tensão na ruptura entre 19 e $35 \mathrm{MPa}$ para os filmes com menor concentração de plastificante, e entre 15 e $22 \mathrm{MPa}$ no caso dos filmes com maior concentração de plastificante, ou seja, todos os valores se encontram abaixo dos apresentados no presente trabalho [Q100, Figura 85-b]. Li e colaboradores desenvolveram compósitos de quitosana reforçados com whiskers de celulose de linter de algodão, e obtiveram valores de tensão na ruptura entre 16 e $18 \mathrm{MPa}$ para concentrações de 15\% em massa de whiskers, valores que também se encontram abaixo dos obtidos no presente estudo. Valores maiores de tensão na ruptura [entre 85 e 115 MPa] puderam ser encontrados quando as medidas foram realizadas após a imersão dos corpos de prova em água por 30 min [LI, ZHOU e ZHANG, 2009]. Sriupayo e colaboradores [SRIUPAYO et al., 2005] prepararam nanocompósitos de quitosana reforçados com whiskers de $\alpha$-quitina com concentrações entre 0,74-29,6\% em massa. Os resultados de tensão na ruptura do filme de quitosana sem reforço levaram a uma média de $65 \mathrm{MPa}$, o que se aproxima do valor obtido no presente trabalho (69 MPa, Figura 85-b]. A adição dos whiskers de quitina levaram a um aumento nos valores de tensão na ruptura, para aproximadamente $84 \mathrm{MPa}$, não ocorrendo variação significativa em função da porcentagem de whisker no compósito, e estes valores estão um pouco acima dos encontrados no presente trabalho. Chen e colaboradores [CHEN et al., 2009] usaram a mesma matriz de quitosana para a produção de compósitos reforçados com 
lignina, em concentrações entre 5 e 35\% em massa. O filme de quitosana não reforçado apresentou tensão na ruptura de 43,3 MPa, valor que é consideravelmente menor que os valores encontrados no presente trabalho para o filme correspondente $[Q 100$, Figura 85-b]. A adição de lignina aumentou a resistência à tração até 20\% de lignina, atingindo aproximadamente $68 \mathrm{MPa}$, e este valor diminui para concentrações maiores de lignina. No caso deste trabalho, todos os filmes produzidos, mesmo os reforçados, apresentaram valores menores do que os obtidos no presente estudo. Considerando os resultados da literatura correspondentes a filmes só de quitosana e/ou quitosana/celulose, assim como outras misturas [whiskers de quitina, lignina], os resultados do presente estudo estão acima ou no mesmo patamar da maior parte dos estudos considerados. No entanto, para que as propriedades mecânicas reflitam uma significativa ação como reforço das fibras celulósicas sobre a matriz de quitosana, em macro, micro ou nanoescala, os processos devem ser aprimorados, assim como maiores porcentagens de polpa devem ser consideradas.

\subsubsection{Avaliação morfológica}

As imagens contidas na Figura 86, obtidas a partir de um microscópio eletrônico de varredura de emissão de campo [FEG-MEV], correspondem à morfologia dos filmes obtidos em diferentes concentrações de celulose/quitosana, para polpas com diferentes tratamentos. 

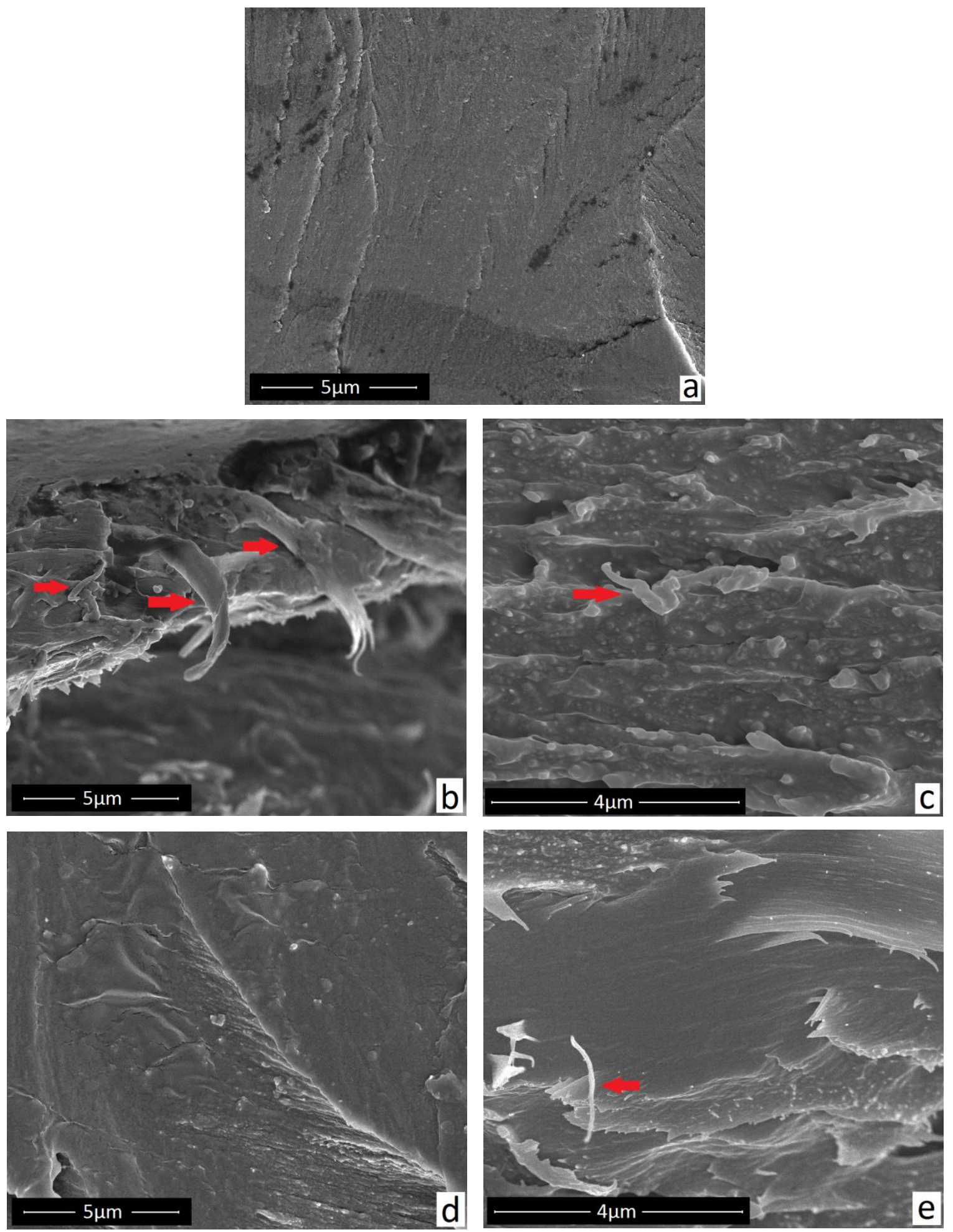

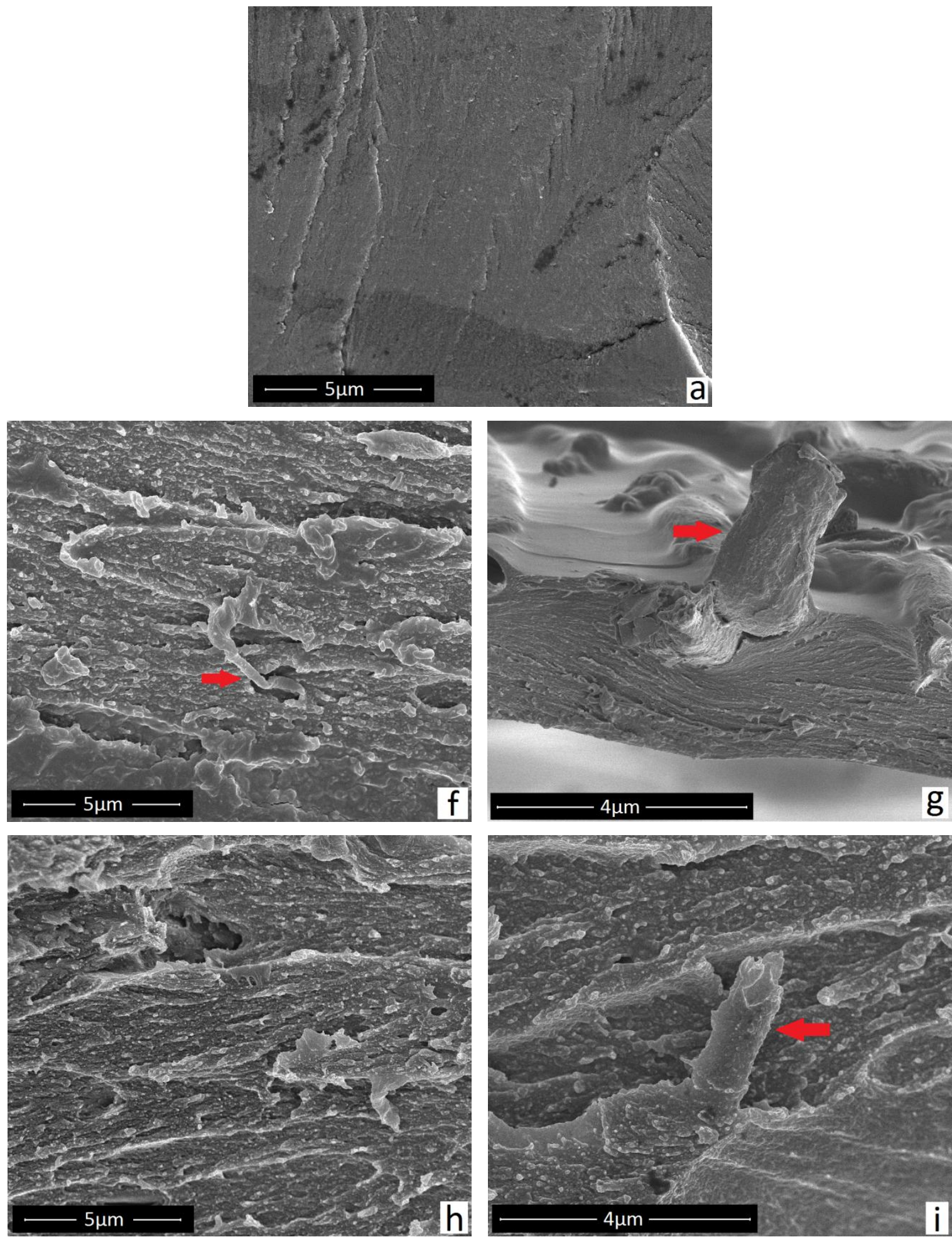

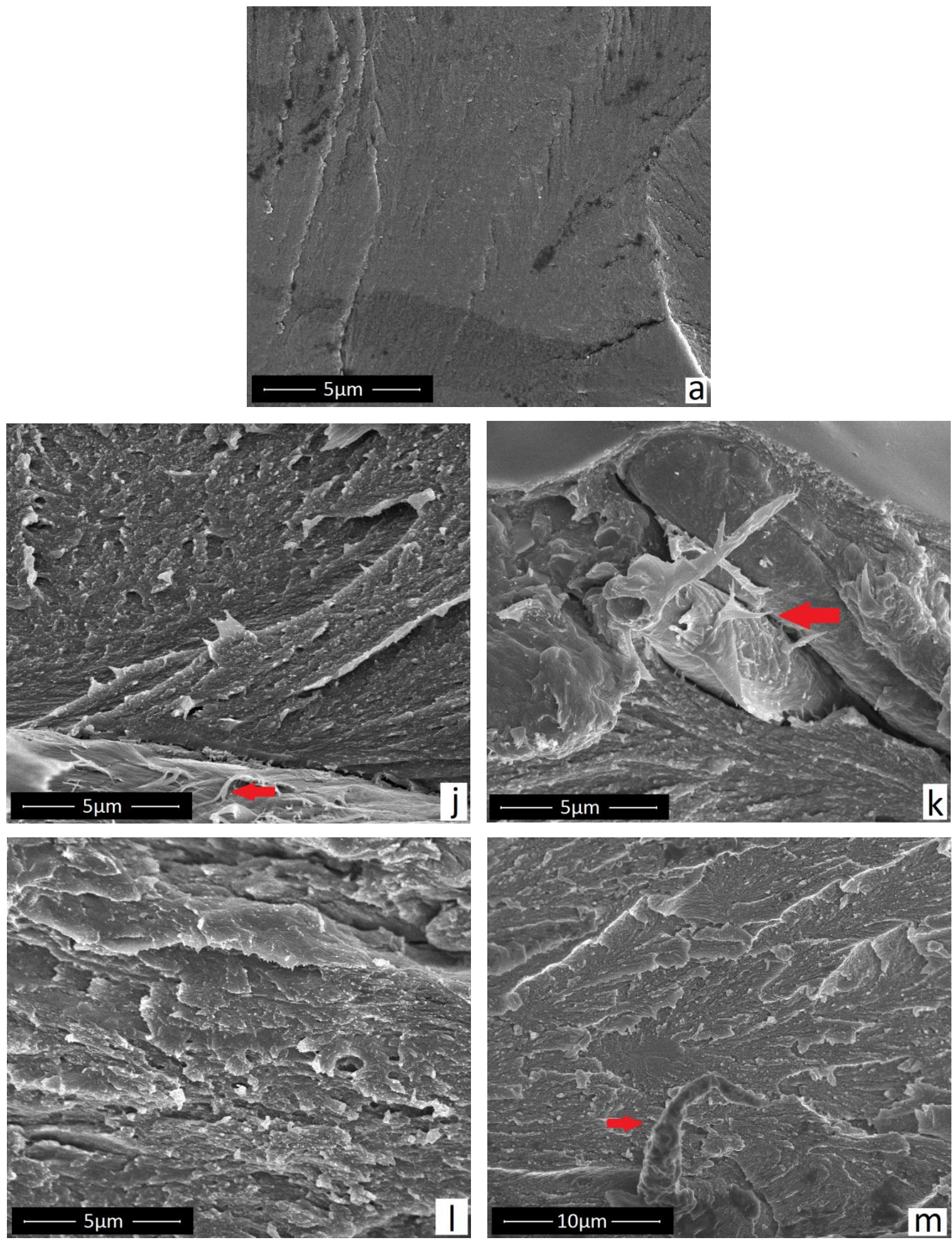

Figura 86 - Micrografias do corte transversal dos filmes [a] Q100, (b) QPST2,5, [c] QPM2,5, [d] QNC2,5, (e) QHE2,5, (f) QPST7,5, (g) QPM7,5, (h) QNC7,5, (i) QHE7,5, (j) QPST15, (k) QPM15, (l) QNC15 e (m) QHE15. 
As imagens da Figura $\mathbf{8 6}$ correspondem à seção transversal das fraturas [corpos de prova dos ensaios de tração] dos filmes de quitosana e quitosana/celulose, nas diferentes concentrações [2,5, 7,5 e 15\%] e pré-tratamentos empregados à polpa.

É possivel observar que, em todos os casos, a adição das fibras de celulose provocou o surgimento de rugosidades e descontinuidades na matriz de quitosana, já que o filme Q100 apresenta seção transversal mais lisa e homogênea (Figura 86-a) quando comparada com os demais filmes. Nota-se que, com exceção do filme produzido com nanocristais de celulose obtidos por hidrólise ácida [QNC, Figura 86-h,i,j], a presença de estruturas fibrilares de celulose em escala micrométrica ao longo da matriz de quitosana [destacadas pelas setas vermelhas], o que é esperado para os filmes produzidos com polpa sem tratamento e mercerizada [QPST e QPM] e, no caso dos filmes gerados a partir da polpa que passou por hidrólise enzimática, é uma informação importante, que indica que o tratamento enzimático, ao contrário do ácido, não foi capaz de produzir estruturas somente em escala nanométrica, sendo que possivelmente há uma mistura de micro e nanofibras de celulose ao longo da matriz de quitosana. Este fator contribui para a heterogeneidade dos filmes, observada pelos ensaios mecânicos.

De fato, foi possivel produzir e isolar nanocristais de celulose por hidrólise ácida, o que foi indicado pela ausência de estruturas fibrilares nos filmes gerados com este material [QNC2,5, QNC7,5 e QNC15, Figura 86-d,h,I], e pode ser confirmado com o uso da microscopia eletrônica de varredura de emissão de campo [FEG-MEV] em campo claro [Bright Field, BF], de suspensão diluída contendo os nanocristais [Figura 87]. 


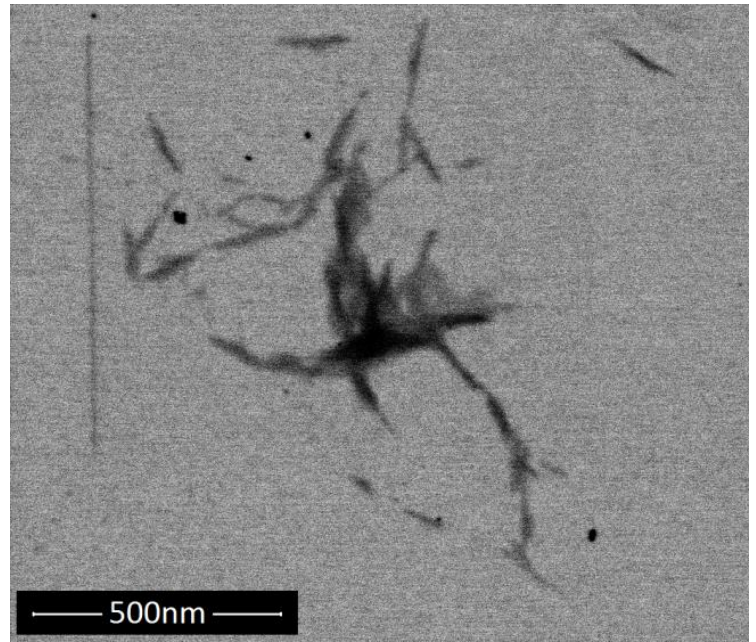

Figura 87 - Micrografia dos nanocristais de celulose obtidos por hidrólise ácida.

No caso da hidrólise enzimática, também foi possivel observar a presença de estruturas em escala nanométrica [Figura 88) com o uso da microscopia eletrônica de varredura de emissão de campo [FEG-MEV], em campo escuro anular em alto ângulo (High Angular Anular Dark Fileld, HAADF]. Entretanto, como pode ser observado pela Figura 86-e,i,m, a reação de hidrólise enzimática gerou também fibras em escala micrométrica, o que sugere a necessidade de desenvolver um método eficaz de isolamento do material de interesse, ou seja, aquele que possui dimensões de nanômetros, além de avaliar suas características intrínsecas, potenciais para sua aplicação como reforço em materiais.

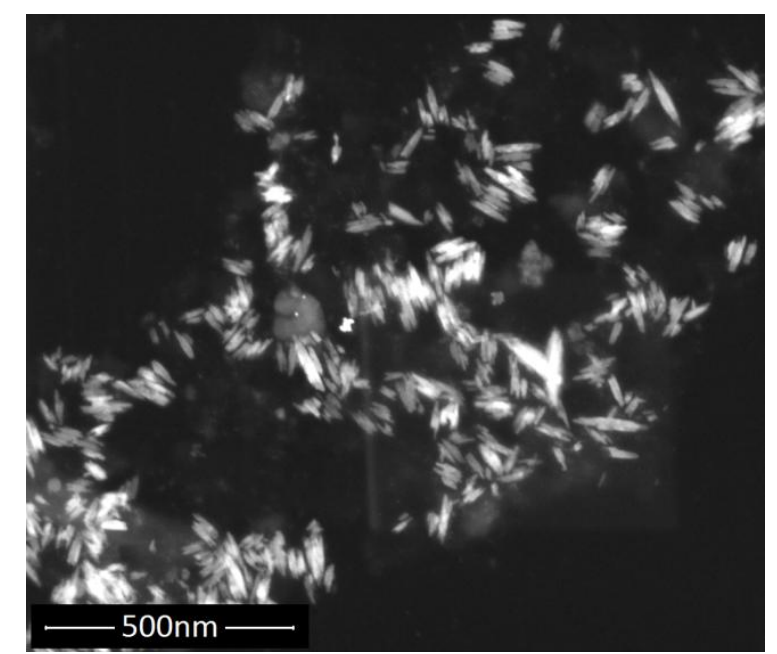

Figura 88 - Micrografia das nanoestruturas de celulose obtidas por hidrólise enzimática. 


\subsection{CONCLUSÕES PARCIAIS}

No geral, a adição de polpa celulósica à matriz de quitosana levou a filmes que, quando submetidos à tração, apresentaram módulo, tensão e deformação na ruptura inferiores ou no mesmo patamar do filme de 100\% de quitosana [Q100]. Comparando os processos de hidrólise ácida e enzimática, a maior eficiência da hidrólise ácida na produção de estruturas que, quando combinadas, resistem mais à solicitação mecânica, uma vez que os filmes produzidos com todas as concentrações testadas de polpa que passou por hidrólise enzimática apresentaram resultados de propriedades mecânicas consideravelmente menores do que aqueles correspondentes ao filme de quitosana, enquanto os filmes produzidos com nanocristais de celulose obtidos por hidrólise ácida corresponderam ao melhor conjunto de resultados, com propriedades mecânicas próximas ou superiores à Q100. Considerando os resultados da literatura correspondentes a filmes só de quitosana e/ou quitosana/celulose, assim como outras misturas, os resultados do presente estudo estão acima ou no mesmo patamar da maior parte dos estudos considerados.

Pelas imagens de microscopia eletrônica de varredura de emissão de campo [FEG-MEV] foi possível observar que, em todos os casos, a adição das fibras de celulose provocou o surgimento de rugosidades e descontinuidades na matriz de quitosana, já que o filme Q100 apresenta seção transversal mais lisa e homogênea quando comparada com os demais filmes. Nota-se, com exceção do filme produzido com nanocristais de celulose obtidos por hidrólise ácida, a presença de estruturas fibrilares de celulose em escala micrométrica ao longo da matriz de quitosana.

Foram produzidos nanocristais de celulose por hidrólise ácida, o que corresponde a estruturas muito usadas como reforço em matriz polimérica. No caso da hidrólise 
enzimática, também foi possível observar a formação de estruturas em escala nanométrica. Entretanto, não foi possível isolar este material das fibras que permaneceram em escala micrométrica, o que sugere a necessidade de desenvolver um método eficaz de isolamento das nanoestruturas de celulose obtidas via hidrólise enzimática e avaliar a potencialidade de serem aplicadas como reforço em materiais. E de aumentar a população de fibras nesta escala, umas vez que ainda estavam presentes no meio fibras em dimensões micrométricas. 


\section{Capítulo}

\section{CONCLUSÕES GERAIS}

A natureza das fibras lignocelulósicas exerce forte influência nos processos a que são submetidas, como, no caso deste estudo, a hidrólise. Assim, a utilização de polpa de sisal em novos processos impõe que estudos detalhados sejam realizados, como foi pretendido no presente trabalho.

0 objetivo geral deste estudo constituiu em proporcionar um melhor entendimento e consequente melhoria do processo de hidrólise de polpa de sisal, com a perspectiva de utilização da glicose para a produção de etanol e de fibras em escala micro e nanométrica para posterior aplicação em materiais, objetivo que foi realizado com sucesso, uma vez que o conjunto de resultados descritos neste texto contribuem de forma positiva com os dados já existentes na literatura acerca das reações de hidrólise ácida e enzimática de biomassa.

A análise da polpa residual retirada durante o curso das reações mostrou que é possível gerar, com o uso de ácido sulfúrico ou ácido oxálico como catalisador, celulose de 
alta cristalinidade e baixa massa molar média [características de celulose microcristalina].

Os resultados das reações de sacarificação de polpa de sisal mostraram a importância do tratamento alcalino [mercerização] para a produção de açúcares, pois elimina hemiceluloses e diminui a cristalinidade e a massa molar média da celulose presente na polpa. Dentre todas as condições de hidrólise ácida da polpa de sisal estudadas, a que levou a melhores rendimentos foi uma reação envolvendo polpa mercerizada e ácido sulfúrico como catalisador, em um intervalo de tempo de 5,5h. As reações envolvendo ácido oxálico como catalisador envolveram maior tempo até atingir concentração máxima de glicose, o que acarreta em maior custo energético. Entretanto, destaca-se a possibilidade de obtenção do ácido oxálico a partir de fontes renováveis. Ainda, o valor calculado para $E_{a}$ da reação com ácido oxálico é maior do que aquele observado para a reação com ácido sulfúrico nas mesmas condições.

No que diz respeito às reações de hidrólise enzimática de polpa de sisal, comparou-se a eficiência de dois pré-tratamentos da polpa, ou seja, mercerização e tratamento com ácido oxálico. Ao comparar os teores de glicose formados nos dois casos, ficou evidente a melhor eficiência da mercerização como pré-tratamento das fibras, uma vez que, neste caso, o teor máximo de glicose encontrado no licor chega a ser até 2,5 vezes maior que o máximo teor de glicose encontrado quando a polpa tratada com ácido oxálico foi usada como material de partida.

Com relação aos filmes de quitosana/celulose gerados, pode-se constatar que a adição de polpa celulósica à matriz de quitosana levou a filmes que, quando submetidos à tração, apresentaram módulo, tensão e deformação na ruptura inferiores ou no mesmo patamar do filme de $100 \%$ de quitosana (Q100). Considerando os resultados da literatura correspondentes a filmes só de quitosana e/ou quitosana/celulose, assim 
como outras misturas, os resultados do presente estudo estão acima ou no mesmo patamar da maior parte dos estudos considerados.

Foram produzidos nanocristais de celulose por hidrólise ácida, o que corresponde a estruturas muito usadas como reforço em matriz polimérica. No caso da hidrólise enzimática, também foi possível observar a formação de estruturas em escala nanométrica, mas há ainda a necessidade aumentar a população de fibras nesta escala, umas vez que ainda estavam presentes no meio fibras em dimensões micrométricas. 


\section{Capítulo}

\section{5}

\section{ANEXOS}

As equações a seguir mostram como foram feitos os cálculos para a obtenção dos valores aproximados de glicose potencial.

[glicose potencial] $=[$ glicose $]+([H M F] \times y)+([a ́ c$. fórm. $] \times z)$

Em que "y" e "z" são, respectivamente, fatores de conversão de HMF e ácido fórmico para glicose. Neste caso, y=1,28 e z=3,52 são obtidos pelas razões entre as massas molares de cada composto com seu respectivo composto de origem. Dessa forma, a concentração de glicose que se decompôs a HMF é o valor de concentração de HMF multiplicado por "y":

$$
y=\frac{M M_{\text {glicose }}}{M M_{H M F}}=\frac{162 \mathrm{gmol}^{-1}}{126 \mathrm{gmol}^{-1}}=1,28
$$


E a concentração de glicose que se decompôs a ácido fórmico é o valor de concentração encontrado para ácido fórmico multiplicado por "z":

$$
z=\frac{M M_{a c . f o r m}}{M M_{H M F}} \times \frac{M M_{\text {glicose }}}{M M_{H M F}}=\frac{46 \mathrm{gmol}^{-1}}{126 \mathrm{gmol}^{-1}} \times \frac{162 \mathrm{gmol}^{-1}}{126 \mathrm{gmol}^{-1}}=3,52
$$

Neste caso, ácido fórmico é proveniente da decomposição de HMF, portanto "z" é gerado a partir de duas etapas, uma para calcular quanto de HMF se decompôs a ácido fórmico e outra para calcular quanto de glicose levou a formação de HMF.

Considerando que a xilose representa $68 \%$ do total de hemiceluloses da fibra de sisal, é possível estimar se toda hemicelulose contida na polpa foi hidrolisada nas condic̣ões consideradas nas reações. Para isso, é calculado o quanto de xilose há no licor, se toda poliose for hidrolisada, considerando o total em massa de hemiceluloses presentes na celulose.

$$
[\text { xilose }]_{\max }=\frac{\text { massa }_{\text {polpa }} \times \% \text { hemiceluloses }}{V_{\text {solução }}} \times w \times 68 \%
$$

Em que "w" corresponde ao fator de conversão de anidroxilose [xilose nas hemiceluloses] para xilose no licor, que diferem em massa por uma molécula de água.

$$
w=\frac{M M_{\text {xilosellicor }}}{M M_{\text {xilosel polioses }}}=\frac{150 \mathrm{gmol}^{-1}}{132 \mathrm{gmol}^{-1}}=1,14
$$

Assim, a concentração máxima de xilose que poderia ser encontrada considerando que $30 \mathrm{~g}$ de polpa foram adicionadas a $900 \mathrm{~mL}$ de solução ácida, é de:

$$
[\text { xilose }]_{\max } \leq \frac{(30 \times \% \text { hemiceluloses }) g}{0,9 L} \times w \times 68 \%
$$




\section{Capítulo}

\section{REFERÊNCIAS BIBLIOGRÁFICAS}

ABASAEED, A.E. Kinetic and process studies on free and solid acid catalyzed hydrolysis of biomass substrates. 1987. $191 \mathrm{f}$. Tese [Doutorado] - Universidade de Auburn, Alabama, 1987.

AGOPYAN, V:; SAVASTANO JUNIOR, H.; JOHN, V.M.; CINCOTTO, M.A. Developments on vegetable fibre-cement based materials in São Paulo, Brazil: an overview. Cement and Concrete Composites v. 27, p. 527-536, 2005.

AGUILAR, R.; RAMIIREZ, J.A.; GARROTE, G.; VÁZQUEZ, M. Kinetic study of the acid hydrolysis of sugar cane bagasse. Journal of Food Engineering, v. 55, p. 309-318, 2002.

AGULLÓ, E.; PENICHE, C.; TAPIA, C.; HERAS, Á.; ROMÁN, J.S.; ARGÜLLES, W.; GOYCOOLEA, F.; MAYORGA, A.; NAKAMATSU, J.; ABRAM, A.P. Quitina y Quitosano: obtención, caracterización y aplicaciones. Perú: Pontificia Universidad Católica Del Perú/Fondo Editorial, 2004. 312 p.

ÅKESSON, D.; SKRIFVARS, M.; SEPPÄLÄ, J.; TURUNEN, M. Thermoset lactic-based resin as a matrix for flax fibers. Journal of Applied Polymers Science, v. 119, n. 5, p. 30043009, 2011. 
ALMEIDA, E.V.R. Valorização da celulose de sisal: uso na preparação de acetatos e de filmes de acetatos de celulose/celulose e quitosana/celulose. 2009. $158 \mathrm{f}$. Tese [Doutorado em Físico-Química] - Instituto de Química de São Carlos, Universidade de São Paulo, São Carlos, 2009.

ALMEIDA, E.V.R.; FROLLINI, E.; CASTELLAN, A.; COMA, V. Chitosan, sisal cellulose, and biocomposite chitosan/sisal cellulose films prepared from thiourea/ $\mathrm{NaOH}$ aqueous solution. Carbohydrate Polymers, v. 80, n. 3, p. 655-664, 2010.

AMERICAN SOCIETY FOR TESTING AND MATERIALS. Standard terminology of cellulose and cellulose derivatives. Philadelphia, 2007. D1695-07.

AMERICAN SOCIETY FOR TESTING AND MATERIALS. Standard test method for tensile properties of plastics. Philadelphia, 2003. D638-03.

AMIJI, M.M. Permeability and blood compatibility properties of chitosan-poly[ethylene oxide) blend membranes for haemodialysis. Biomaterials, v. 16, n. 8, p. 593-599, 1995.

ARANTES, V.; SADDLER, J.N. Access to cellulose limits the efficiency of enzymatic hydrolysis: the role of amorphogenesis. Biotechnology for Biofuels, v. 3, p. 1-11, 2010.

ARAUJO, R.H. Celulose kraft produzida a partir das madeiras de bracatinga (Mimosa scabrella] e eucalipto [Eucalyptus saligna] misturadas em diferentes proporções. 2004. 99 f. Dissertação [Mestrado em Engenharia Florestal] - Universidade Federal de Santa Maria, Santa Maria, 2004.

ASPINALL, G.O. Chemistry of cell wall polysaccharides. In: STUMPF, P.K.; CONN, E.E. [Ed.]. The biochemistry of plants. London: Academic Press, 1980. v. 3, p. 473-500.

ASS, B.A.P.; BELGACEM, M.N.; FROLLINI, E. Mercerized linters cellulose: characterization and acetylation in N,N-dimethylacetamide/lithium chloride. Carbohydrate Polymers, v. 63, n. 1, p. 19-29, 2006.

ASS, B.A.P.; CIACCO, G.T.; FROLLINI, E. Cellulose acetates from linters and sisal: correlation between synthesis conditions in DMAc/LiCl and product properties. Bioresource Technology, v. 97, n. 14, p. 1696-1702, 2006.

ASSOCIAC̣ÃO BRASILEIRA DE CELULOSE E PAPEL [BRACELPA]. Celulose. Disponível em: <http://www.bracelpa.org.br>. Acesso em: 07 jan. 2012.

ATALLA, R.H.; VANDERHART, D.L. Native cellulose - a composite of 2 distinct crystalline forms. Science, v. 223, n. 4633, p. 283-285, 1984. 
ATKINS, P.; JONES, L. Princípios de química: questionando a vida moderna e o meio ambiente. Tradução de Ricardo Bicca de Alencastro. 3. ed. Porto Alegre: Bookman, 2006.

BALAT, M.; BALAT, H.; ÖZ, C. Progress in bioethanol processing. Progress in Energy and Combustion Science v. 34, p. 551-573, 2008.

BARBOSA JUNIOR, V.B.; RAMIRES, E.C.; RAZERA, I.A.T.; FROLLINI, E. Biobased composites from tannin-phenolic polymers reinforced with coir fibers. Industrial Crops and Products, v. 32, n. 3, p. 305-312, 2010.

BATTISTA, O.A.; COPPICK, S.; HOWSMON, J.A.; MOREHEAD, F.F.; SISSON, W.A. Level-off degree of polymerization: relation to polyphase structure of cellulose fibers. Industrial \& Engineering Chemistry, v. 48, p. 333-335, 1956.

BELDMAN, G.; SEARLE-VAN LEEUWEN, M.F.; ROMBOUTS, F.M.; VORAGEN, F.G.J. The cellulase of Trichoderma viride. European Journal of Biochemistry, v. 146, p. 301-308, 1985.

BELDMAN, G.; VORAGEN, F.G.J.; ROMBOUTS, F.M.; SEARLE-VAN LEEWEN, M.F.; PILNIK, W. Specific and nonspecific glucanases from Trichoderma viride. Biotechnology and Bioengineering, v. 31, p. 160-167, 1988.

BELGACEM, M. N.; GANDINI, A. Monomers, polymers and composites from renewable resources. London: Elsevier, 2008. 560 p.

BILLMEYER JÚNIOR, F.W. Textbook of polymer science. 3rd ed. New York: WileyInterscience, 1984. 578 p.

BLAU, G. The use of charcoal in steel-industry of Brazil. Stahl Und Eisen, v. 98, n. 24, p. 1297-1301, 1978.

BONDERSON, D.; MATHEW, A.; OKSMAN, K. Optimization of the isolation of nanocrystals from microcrystalline cellulose by acid hydrolysis. Cellulose, v. 13, n. 2, p. 171-180, 2006.

BORDENAVE, N.; GRELIER, S.; PICHAVANT, F.; COMA, V. Water and moisture susceptibility of chitosan and paper-based materials: Structure-properties relationships. Journal of Agricultural and Food Chemistry, v. 55, p. 9479-9488, 2007.

BOURTOOM, T.; CHINNAN, M.S. Preparation and properties of rice starch-chitosan blend biodegradable film. LWT Food Science and Technology, v. 41, n. 9, p. 1633-1641, 2008.

BRITO, J.O. Charcoal in Brazil: Economic and environmental management. Estudos

Avançados n. 9, p. 1-7, 1990. 
BROWNING, B. L. Methods of wood chemistry. New York: Interscience, 1967. v. 2.

BUDAVARI, S. [Ed.]. The MERCK index: an encyclopedia of chemicals, drugs and biological. 12. Ed. Whitehouse Station: Merck, 1996. 1v.

BURTON, R.A.; GIDLEY, M.J.; FINCHER, G.B. Heterogeneity in the chemistry, structure and function of plant cell walls. Nature Chemical Biology, v. 6, p. 724-732, 2010.

BUSCHLE-DILLER, G.; ZERONIAN, S.H. Enhancing the reactivity and strenght of cotton fibres. Journal of Applied Polymer Science, v. 45, p. 967-979, 1992.

BUSTOS, G.; RAMIREZ, J.A.; GARROTE, G.; VAZQUEZ, M. Modeling of the hydrolysis of sugarcane bagasse with hydrochloric acid. Applied Biochemistry and Biotechnology, v. 104, p. 51-68, 2003.

BUTLER, B.L.; VERGANO, P.J.; TESTIN, R.F.; BUNN, J.M.; WILES, J.L. Mechanical and barrier properties of edible chitosan films as affected by composition and storage. Journal of Food Science, v. 61, n. 5, p. 953-957, 1996.

CANER, C.; CANSIZ, O. Effectiveness of chitosan-based coating in improving shelf-life of eggs. Journal of the Science of Food Agriculture, v. 87, p. 227-232, 2007.

CANER, C.; VERGANO, P.J.; WILLES, J.L. Chitosan film mechanical and permeation properties as affected by acid, plasticizer, and storage. Journal of Food Science, v. 63, n. 6, p. 1049-1053, 1998.

CHANG, P.R.; JIAN, R.; ZHENG, P.; YU, J.; MA, X. Preparation and properties of glycerol plasticized-starch [GPS]/cellulose nanoparticle [CN] composites. Carbohydrate Polymers, v. 79, n. 2, p. 301-305, 2010.

CHEN, L.; TANG, C.-Y.; NING, C.-Y.; WANG, C.-Y.; FU, Q.; ZHANG, Q. Preparation and properties of chitosan/lignin composite films. Chinese Journal of Polymers Science, v. 27, n. 5, 739-746, 2009.

CHEUNG, S.W.; ANDERSON, B.C. Laboratory investigation of ethanol production from municipal primary wastewater. Bioresource Technology, v. 59, p. 81-96, 1997.

CHO, D.H.; SHIN, S.J.; BAE, Y.; PARK, C.; KIM, Y.H. Ethanol production from acid hydrolysates based on the construction and demolition wood waste using Pichia stipites. Bioresource Technology, v. 102, p. 4439-4443, 2011. 
CIACCO, G.T. Celulose de sisal e bagaço de cana-de-açúcar: esterificação em meio homogêneo. 2003. 153 f. Dissertação [Mestrado em Ciências] - Instituto de Química de São Carlos, Universidade de São Paulo, São Carlos, 2003.

COLLINS, E.A.; BARES , J.; BILLMEYER JUNIOR, F.W. Experiments in polymer science. New York: John Wiley, 1973. 542 p.

COUGHLAN, M.P.; LJUNGDAHL, L.G. Comparative biochemistry of fungal and bacterial cellulolytic enzyme systems. In: AUBERT, J.P.; BÉGUIN, P.; MILLETT, J. [Ed.]. Biochemistry and genetics of cellulose degradation. New York: Academic Press, 1988. p. 11-30.

COWLING, E. B.; KIRK, T. K. Properties of cellulose and lignocellulosic materials as substrates for enzymatic conversion processes. Biotechnology and Bioengineering, n. 6, p. 95-123, 1976.

CURVELO, A.A.S. Biorrefinaria: a matéria-prima definindo o processamento. Disponível em: <http:/ / www.revistaopinioes.com.br/cp/materia.php?id=250>. Acesso em: 18 jan. 2012 .

DAWSEY, T.R.; McCORIICK, C.L. The lithium chloride/dimethylacetamide solvente for celulose: a literature review. Journal of Molecular Structure, v. 30, n. 314, p. 405-440, 1990.

DE PAULA, M.P. Hidrólise ácida de polpa de sisal: características do processo heterogêneo e estudo das reações correlatas. 2009. 142 f. Dissertação [Mestrado em Ciências] - Instituto de Química de São Carlos, Universidade de São Paulo, São Carlos, 2009.

DE PAULA, M.P.; LACERDA, T.M., ZAMBON, M.D., FROLLINI, E. Adding Value to the Brazilian sisal: acid hydrolysis of its pulp seeking production of sugars and materials. Cellulose, 2012. Disponível em:

<http:/ / www.springerlink.com/content/k45rp473x2460126/>. Acesso em: 22 mar. 2012.

DE PAULA, M.P.; LACERDA, T.M.; FROLLINI, E. Sisal cellulose acetates obtained from heterogeneous reactions. Express Polymer Letters, v. 2, n. 6, p. 423-428, 2008.

DEAN, B.; DODGE, T.; VALLE, F.; CHOTANI, G. Development of biorefineries - technical and economic considerations. In: KAMM, B.; GRUBER, P.R.; KAMM, M. [Ed.). Biorefineries: industrial processes and products. New York: Wiley, 2006. p. 67-83. 
DELEZUK, J.A.M. Desacetilação de beta-quitina assistida por ultrassom de alta intensidade: estudo dos efeitos da amplitude e do tempo de irradiação e da temperatura de reação. 2009. 97 f. Dissertação [Mestrado em Ciências] - Instituto de Química de São Carlos, Universidade de São Paulo, São Carlos, 2009.

DINAND, E.; VIGNON, M.; CHANZY, H.; HEUX, L. Mercerization of primary wall cellulose and its implication for the conversion of cellulose I $\rightarrow$ cellulose II. Cellulose, v. 9, p. 7-18, 2002.

DING, S.Y.; HIMMEL, M.E. The maize primary cell wall microfibril: a new model derived from direct visualization. Journal of Agricultural and Food Chemistry, v. 54, p. 597-606, 2006.

EBRINGEROVA, A.; HEINZE, T. Xylan and xylan derivatives - biopolymers with valuable properties, 1 - naturally occurring xylans structures, procedures and properties.

Macromolecular Rapid Communications, v. 21, n. 9, p. 542-556, 2000.

EICHHORN, S.J.; DUFRESNE, A.; ARANGUREN, M.; MARCOVICH, N.E.; CAPADONA, J.R.; ROWAN, S.J.; WEDER, C.; THIELEMANS, W.; ROMAN, M.; RENNECKAR, S.; GINDL, W.; VEIGEL, S.; KECKES, J.; YANO, H.; ABE, K.; NOGI, M.; NAKAGAITO, A.N.; MANGALAM, A.; SIMONSEN, J.; BENIGHT, A.S.; BISMARCK, A.; BERGLUND, L.A., PEIJS, T. Review: current international research into cellulose nanofibres and nanocomposites. Journal of Materials Science, v. 45, n. 1, p. 1-33, 2010.

FANG, L.; GOH, S.H. Miscible Chitosan/Tertiary Amide Polymer Blends. Journal of Applied Polymer Science, v. 76, n. 12, p. 1785-1790, 2000.

FAVIER, V.; CANOVA, G.R.; CAVAILLÉ, J.Y.; CHANZY, H.; DUFRESNE, A.; GAUTHIER, C. Nanocomposite materials from latex and cellulose whiskers. Polymers for Advanced Technologies, v. 6, n. 5, p. 351-355, 1995a.

FAVIER, V.; CAVAILLÉ, J.Y:; CANOVA, G.R.; SHRIVASTAVA, S.C. Mechanical percolation in cellulose whisker nanocomposites. Polymer Engineering \& Science, v. 37, n. 10, p. 17321739, 1997.

FAVIER, V.; CHANZY, H.; CAVAILLÉ, J.Y. Polymer nanocomposites reinforced by cellulose whiskers. Macromolecules, v. 28, n. 18, p. 6365-6367, 1995b.

FENGEL, D.; WEGENER, G. Wood: chemistry, ultrastructure, reactions. New York: Walter de Gruyter, 1984. 613 p.

FERNANDES, S.C.M.; FREIRE, C.S.R.; SILVESTRE, A.J.D.; PASCOAL NETO, C.; GANDINI, A. Novel materials based on chitosan and cellulose. Polymer International, v .60, p. 875882, 2011. 
FINK, H. P.; WALENTA, E.; KUNZE, K.; MANN, G. Wide angle X-ray and solid state ${ }^{13} \mathrm{C}$ NMR studies of cellulose alkalization. In: KENNEDY, J.F.; PHILLIPS, G.O.; WILLIAMS, P.A.; PICULELL, L. [Ed.]. Cellulose and cellulose derivatives: Physicochemical aspects and industrial applications. Cambridge: Woodhead Publishing, 1995. p. 523-528.

FOOD AND AGRICULTURAL ORGANIZATION OF THE UNITED NATIONS [FAO). Statistics. Disponivel em: <http://www.fao.org>. Acesso em: 8 jan. 2012.

FROLLINI, E. Lignina como substituta parcial de fenol em espumas e compósitos reforçados com fibras lignocelulósicas. 2002. 38 f. Tese (Livre Docência), Instituto de Química de São Carlos, Universidade de São Paulo, São Carlos, 2002.

FUKUZUMI, H.; SAITO, T.; WATA, T.; KUMAMOTO, Y.; ISOGAI, A. Transparent and high gas barrier films of cellulose nanofibers prepared by TEMPO-mediated oxidation.

Biomacromolecules, v. 10, n. 1, p. 162-165, 2009.

GÁMEZ, S.; RAMÍREZ, J. A.; GARROTE, G.; VÁZQUEZ, M. manufacture of fermentable sugar solutions from sugar cane bagasse hydrolyzed with phosphoric acid at atmospheric pressure. Journal of Agricultural and Food Chemistry, v. 52, p. 4172-4177, 2004.

GANDINI, A. Polymers from renewable resources: a challenge for the future of macromolecular materials. Macromolecules, v. 41, p. 9491-9504, 2008.

GANDINI, A. The irruption of polymers from renewable resources on the scene of macromolecular science and technology. Green Chemistry, v. 13, p. 1061-1083, 2010.

GARVES, K. Temperature, salt, and acidity effects on the hydrolysis of cellulose dissolved in concentrated acids. Cellulose Chemistry and Technology, v. 30, p. 3-12, 1996.

GURGEL, L.V.A. Hidrólise ácida de bagaço de cana-de-açúcar: estudo cinético da sacarificação de celulose para produção de bioetanol. 2010. 315 f. Tese [Doutorado] Instituto de Química de São Carlos, Universidade de São Paulo, São Carlos, 2010.

GÜRÜ, M.; BILGESÜ, A.Y.; PAMUK, V. Production of oxalic acid from sugar beet molasses by formed nitrogen oxides. Bioresource Technology, v. 77, p. 81-86, 2001.

GUSAKOV, V.; SINITSYN, A.P.; KLYOSOV, A.A. Kinetics of the enzymatic hydrolysis of cellulose. 1. A mathematical model for a batch reactor process. Enzyme and Microbial Technology, v. 7, p. 346-352, 1985.

HAMAD, W.Y.; HU, T.Q. Structure-process-yield interrelations in nanocrystalline cellulose extraction. Canadian Journal of Chemical Engineering v. 88, n. 3, p. 392-402, 2010. 
HAMELINCK C.N.; HOOIJDONK, G.; FAAlJ, A. Ethanol from lignocellulosic biomass: technoeconomic performance in short-, middle- and long-term. Biomass Bioenergy, v. 28, p. 384410, 2005.

HAMILTON, L. Firewood and woody biomass and their role in greenhouse gas reduction. Agriculture Notes, p. 1-4, Abril, 2008.

HAN, C.; ZHAO, Y.; LEONARD, S.W.; TRABER, M.G. Edible coatings to improve storability and enhance nutritional value of fresh and frozen strawberries [Fragaria $\times$ ananassa] and raspberries [Rubus ideaus]. Postharvest Biology and Technology, v. 33, n. 1, p. 67-78, 2004.

HARI KRISHNA, S.; CHOWDARY, G.V. Simultaneous saccharification and fermentation of lignocellulosic wastes to ethanol using thermotolerant yeast. Bioresource Technology, v. 77, n. 2, p. 193-196, 2001.

HAYASHI, N.; KONDO, T.; ISHIHARA, M. Enzymatically produced nano-ordered short elements containing cellulose $I_{\beta}$ crystalline domains. Carbohydrate Polymers, v. 61, p. 191-197, 2005.

HEININGEN, V. Converting a kraft pulp mill into an integrated forest biorefinery. Pulp $\boldsymbol{\&}$ Paper Canada, v. 107, n. 6, p. 38-43, 2006.

HETTENHAUS, J. Achieving sustainable production of agricultural biomass for biorefinery feedstock. Industrial Biotechnology, v. 2, n. 4, p. 257-274, 2006.

HIGMAN, C.; VAN DER BURGT, M. Gasification. Amsterdam: Elsevier, 2003. p. 41-219.

HIMMEL, M.E. Biomass recalcitrance: engineering plants and enzymes for biofuels production. Science, v. 316, n. 5827, p. 982-982, 2007.

HON, D.N.-S. Cellulose: a random walk along its historical path. Cellulose, v. 1, n. 1, p. 1-25, 1994.

HUANG, H.J.; LIN, W.L.; RAMASWAMY, S.; TSCHIRNER, U. Process modeling of comprehensive integrated forest biorefinery - an integrated approach. Applied Biochemistry and Biotechnology, v. 154, n. 1-3, p. 205-216, 2009.

INSTITUTO DE PESQUISAS TECNOLÓGICAS DO ESTADO DE SÃO PAULO [IPT). Pasta celulósica: Determinação de viscosidade intrínseca em solução de cuproetilenodiamina [CUEN] com viscosímetro do tipo capilar C26-1996. O Papel, v. 57, n. 9, p. 110-118, 1996. 
INTERNATIONAL UNION OF PURE AND APPLIED CHEMISTRY [IUPAC). Catalyst.

Disponivel em: <http:/ /goldbook.iupac.org>. Acesso em: 13 jan. 2012.

ITOH, H.; WADA, M.; HONDA, Y.; KUWAHARA, M.; WATANABE, T. Bioorganosolve pretreatments for simultaneous saccharification and fermentation of bleech wood by ethanolysis and white rot fungi. Journal of Biotechnology, v. 103, p. 273-280, 2003.

JARVIS, M. Chemistry: Cellulose stacks up. Nature, v. 426, p. 611-612, 2003.

JORGENSEN, H.; KUTTER, J.P.; OLSSON, L. Separation and quantification of cellulases and hemicellulases by capillary electrophoresis. Analytical Biochemistry, v. 317, n. 1, p. 8593, 2003.

KAMM, B.; GRUBER, P.R.; KAMM, M. Biorefineries: industrial processes and products: status quo and future directions. Weinheim: Wiley-VCH, 2006. 462 p.

KAPARAJU, P.; SERRANO, M.; THOMSEN, A.B.; KONGJAN, P.; ANGELIDAKI, I. Bioethanol, biohydrogen and biogas production from wheat straw in a biorefinery concept.

Bioresource Technology, v. 100, n. 9, p. 2562-2568, 2009.

KIM, S.I.K.; LEE, E.S.; YOON, H.S. Mercerization in degassed sodium hydroxide solution. Fibers and Polymers, v. 7, p. 186-190, 2006.

KIM, Y.; JUNG, R.; KIM, H.S.; JIN, H.J. Transparent nanocomposites prepared by incorporating microbial nanofibrils into poly[L-lactic acid]. Current Applied Physics, v. 9, n. 1, p. S69-S71, 2009. Supplement.

KIUCHI, H.; KAI, W.; INOUE, Y. Preparation and characterization of poly[ethylene glycol] crosslinked chitosan films. Journal of Applied Polymer Science, v. 107, n. 6, p. 38233830, 2008.

KLEMM, D.; PHILIPP, B.; HEINZE, T.; HEINZE, U.; WAGENKNECHT, W. Comprehensive cellulose chemistry: fundamentals and analytical methods. Weinheim: Wiley-VHC, 1998. $263 \mathrm{p}$.

KONDO, T. Hydrogen bonds in regioselectively substituted cellulose derivatives. Journal of Polymer Science: Part B: Polymer Physics, v. 32, p. 1229-1236, 1994.

KONDO, T. The relationship between intramolecular hydrogen bonds and certain physical properties of regioselectively substituted cellulose derivatives. Journal of Polymer

Science: Part B: Polymer Physics, v. 35, p. 717-723, 1997. 
KRÄSSIG, H.A. Cellulose: structure, accessibility and reactivity. Amsterdam: Gordon and Breach, 1993. $240 \mathrm{p}$.

KROON-BATENBURG, L.M.J.; KROON, J. The crystal and molecular structures of cellulose I and II. Glycoconjucate Journal, v. 14, n. 5, p. 677-690, 1997.

KROON-BATENBURG, L.M.J.; KROON, J.; NORTHOLT, M.G. Chain modulus and intramolecular hydrogen-bonding in native and regenerated cellulose fibers. Polymer Communications, v. 27, n. 10, p. 290-292, 1986.

KUMAR, R.; WYMAN, C.E. Does change in accessibility with conversion depend on both the substrate and pretreatment technology? Bioresource Technology, v. 100, n. 18, p. 4193-4202, 2009.

LACERDA, T.M. Hidrólise ácida de celulose de sisal. 2007. 87 f. Monografia [Bacharelado] - Instituto de Química de São Carlos, Universidade de São Paulo, São Carlos, 2007.

LACERDA, T.M.; DE PAULA, M.P.; ZAMBON, M.D.; FROLLINI, E. Saccharification of Brazilian sisal pulp: Evaluating the impact of mercerization on non-hydrolyzed pulp and hydrolysis products. Cellulose, v. 19, n. 2, p. 351-362, 2012.

LARSSON, S.; PALMQVIST, E.; HAHN-HÄGERDAL, B.; TENGBORG, C.; STENBERG, K.; ZACCHI, G.; NILVEBRANT, N.O. The generation of fermentation inhibitors during dilute acid hydrolysis of softwood. Enzyme and Microbial Technology, v. 24, p. 151-159, 1999.

LENIHAN, P.; OROZCO, A.; O'NEILL, E.; AHMAD, M.N.M.; ROONEY, D.W.; WALKER, G.M. Dilute acid hydrolysis of lignocellulosic biomass. Chemical Engineering Journal, v. 156, p. 395-403, 2010.

LI, C.; YOSHIMOTO, M.; OGATA, H.; TSUKUDA, N.; FUKUNAGA, K.; NAKAO, K. Effects of ultrasonic intensity and reactor scale on kinetics of enzymatic saccharification of various waste papers in continuous irradiated stirred tanks. Ultrasonics Sonochemistry, v. 12, p. 373-384, 2005.

LI, Q.; ZHOU, J.; ZHANG, L. Structure and properties of the nanocomposite films of chitosan reinforced with cellulose whiskers. Journal of Polymer Science: Part B: Polymer Physics, v. 47, p. 1069-1077, 2009.

LI, Y.; MAI, Y.W.; YE, L. Sisal fibre and its composites: a review of recent developments. Composites Science and Technology, v. 60, p. 2037-2055, 2000. 
LIMA, I.S.; LAZARIN, A.M.; AIROLDI, C. Favorable chitosan/cellulose film combinations for copper removal from aqueous solutions. International Journal of Biological

Macromolecules, v. 36, n. 1-2, p. 79-83, 2005.

LU, Y.; MOSIER, N.S. Kinetic modeling analysis of maleic acid-catalyzed hemicellulose hydrolysis in corner stover. Biotechnology and Bioengineering, v. 101, n. 6, p. $1170-$ 1181, 2008.

LYND, L.R., WEIMER, P.J., VAN ZYL, W.H., PRETORIUS, I.S. Microbial cellulose utilization: fundamentals and biotechnology. Microbiology and Molecular Biology Reviews, v. 66, p. 506-577, 2002 .

MALTA, H.L. Estudos de parâmetros de propagação de fermento [Saccharomyces cerevisiae) para produção de cachaça de alambique. 2006. 70 f. Dissertação (Mestrado em Ciência de Alimentos] - Faculdade de Farmácia, Universidade Federal de Minas Gerais, Belo Horizonte, 2006.

MAMEDES, J.A.; RODRIGUES, M.P.J.; VANISSANG, C.A. Biomassa no Brasil. Revista de divulgação do Projeto Universidade Petrobras e IF Fluminense, v. 1, p. 65-73, 2010.

MANO, E.B. Introdução a polímeros. Rio de Janeiro: Edgard Blücher, 1985. 111 p.

MARABEZI, K. Estudo sistemático das reações envolvidas na determinação dos teores de lignina e holocelulose em amostras de bagaço e palha de cana-de-açúcar. 2009. 158 f. Dissertação [Mestrado em Ciências] - Instituto de Química de São Carlos, Universidade de São Paulo, São Carlos.

MARCHESSAULT, R. H.; MOREHEAD, F. F.; KOCH, J. M. Hydrodynamics properties of neutral suspensions of cellulose crystallites as related to size and shape. Journal of Colloid Science, v. 16, p. 327-344, 1961.

MARTIN, A.R.; MARTINS, M.A.; MATTOSO, L.H.C.; SILVA, O.R.R.F. Caracterização química e estrutural de fibra de sisal da variedade Agave sisalana. Polímeros, v. 19, n. 1, p. 40-46, 2009.

MARZIALETTI, T.; MILLER, S.J.; JONES, C.W.; AGRAWAL, P.K. Switchgrass pretreatment and hydrolysis using low concentrations of formic acid. Journal of Chemical Technology and Biotechnology, v. 86, n. 5, p. 706-713, 2011.

MATSUMO, R.; TANIGUCHI, M.; TANAKA, M.; KAMIKUBO, T. A model for hydrolysis of microcrystalline cellulose by cellulase. Enzyme Engineering, v. 7, p. 158-160, 1984. 
MATTOSO, L.H.C.; FERREIRA, F.C.; CURVELO, A.S. Sisal fiber: Morphology and applications, In: LEÃO, A.L.; CARVALHO, F.X.; FROLLINI, E. [Ed.]. Lignocellulosic/Plastic Composites. São Paulo: USP/UNESP/EMBRAPA, 1997. p. 241-266.

MEGIATTO JÚNIOR, J.D., Fibras de sisal: estudo de propriedades e modificações químicas visando a aplicação em compósitos de matriz fenólica. 2006. 267 f. Tese [Doutorado em Físico-Química] - Instituto de Química de São Carlos, Universidade de São Paulo, São Carlos, 2006.

MEGIATTO JÚNIOR, J.D.; HOAREAU, W.; GARDRAT, C.; FROLLINI, E.; CASTELLAN, A. Sisal Fibers: Surface chemical modification using reagent obtained from a renewable source; characterization of hemicellulose and lignin as model study. Journal of Agricultural and Food Chemistry, v. 55, p. 8576-8584, 2007.

MEGIATTO JÚNIOR, J.D.; SILVA, C.G.; RAMIRES, E.C.; FROLLINI, E. Thermoset matrix reinforced with sisal fibers: effect of the cure cycle on the properties of the biobased composite. Polymer Testing, v. 28, n. 8, p. 793-800, 2009.

MILLETT, M.A.; BAKER, A.J.; SATTER, L.D. Physical and chemical pretreatments for enhancing cellulose saccharification. Biotechnology and Bioengineering, v. 6, p. 125-153, 1976.

MOHAN, D.; PITTMAN, C.U.; STEELE, P.H. Pyrolysis of wood/biomass for bio-oil: a critical review. Energy Fuels, v. 20, p. 848-89, 2006.

MORGADO, D.L. Biocompósitos a partir de celulose de linter: filmes de acetatos de celulose/celulose e quitosana/celulose. 2009. 290 f. Tese [Doutorado em FísicoQuímica] - Instituto de Química de São Carlos, Universidade de São Paulo, São Carlos.

MORGADO, D.L.; FROLLINI, E.; CASTELLAN, A.; ROSA, D.S.; COMA, V. Biobased films prepared from $\mathrm{NaOH}$ /thiourea aqueous solution of chitosan and linter cellulose. Cellulose, v. 18, n. 3, p. 699-712, 2011.

MORIANA, R.; VILAPLANA, F.; KARLSSON, S.; RIBES-GREUS, A. Improved thermomechanical properties by the addition of natural fibers in starch-based sustainable biocomposites. Composites Part A: Applied Science and Manufacturing, v. 42, n. 1, p. 30-40, 2011.

MOSIER, N.S.; SARIKAYA, A.; LADISCH, C.M.; LADISCH, M.R. Characterization of dicarboxilic acids for cellulose hydrolysis. Biotechnology Progress, v. 17, p. 474-480, 2001. 
MOSIER, N.S.; WYMAN, C.; DALE, B.; ELANDER, R.; LEE, Y.Y.; HOLTZAPPLE, M. Features of promising technologies for pretreatment of lignocellulosic biomass. Bioresource Technology, v. 96, p. 673-686, 2005.

MUCHA, M.; PAWLAK, A. Thermal analysis of chitosan and its blends. Thermochimica Acta, v. 427, p. 69-76, 2005.

MWAIKAMBO, L.Y.; ANSELL, M.P. Chemical modification of hemp, sisal, jute, and kapok fibers by alkalization. Journal of Applied Polymer Science, v. 84, n. 12, p. 2222-2234, 2002 .

NAJAFPOUR, G.; IDERIS, A.; SAMANPOUR, S.; NOROUZI, M. Acid hydrolysis of pretreated palm oil lignocellulosic wastes. International Journal of Engineering Transactions B: Applications, v. 20, p. 147-156, 2007.

NATIONAL RENEWABLE ENERGY LABORATORY [NREL]. Determining the cost of producing ethanol from corn starch and lignocellulosic feedstocks. Colorado, 2000. TP-580-28893.

NEVELL, T.P.; ZERONIAN, S.H. Cellulose chemistry fundamentals. In: NEVELL, T.P.; ZERONIAN, S.H. [Ed.]. Cellulose chemistry and its applications. New York: John Wiley, 1985. $552 \mathrm{p}$.

NISHIYAMA, Y.; SUGIYAMA, J.; CHANZY, H.; LANGAN, P. Crystal structure and hydrogen bonding system in cellulose $I_{\alpha}$ from synchrotron $x$-ray and neutron fiber diffraction. Journal of the American Chemical Society, v. 125, n. 47, p. 14300-14306, 2003.

NOGI, M.; IWAMOTO, S.; NAKAGAITO, A.N.; YANO, H. Optically transparent nanofiber paper. Advanced Materials, v. 21, n. 16, p. 1595-1598, 2009.

NORDQVIST, D.; IDERMARK, J.; HEDENQVIST, M. Enhancement of the wet properties of transparent chitosan-acetic-acid-salt films using microfibrillated cellulose.

Biomacromolecules, v. 8, n. 8, p. 2398-2403, 2007.

OLIVEIRA, F.B.; GARDRAT, C.; ENJALBAL, C.; FROLLINI, E.; CASTELLAN, A. Phenol-furfural resins to elaborate composites reinforced with sisal fibers - Molecular analysis of resin and properties of composites. Journal of Applied Polymer Science, v. 109, n. 4, p. 22912303, 2008.

ORTEGA, N.; BUSTO, M.D.; PEREZ-MATEOS, M. Kinetics of cellulose sachafification by Trichoderma reesei cellulases. International Biodeterioration \& Biodegradation, v. 47, n. 1, p. 7-14, 2001. 
ORTS, W.J.; HOLTMAN, K.M.; SEIBER, J.N. Agricultural chemistry and bioenergy. Journal of Agricultural and Food Chemistry, v. 56, n. 11, p. 3892-3899, 2008.

O'SULLIVAN, A.C. Cellulose: the structure slowly unravels. Cellulose, v. 4, n. 3, p. 173-207, 1997.

PAIVA, J.M.F.; FROLLINI, E. Unmodified and modified surface sisal fibers as reinforcement of phenolic and lignophenolic matrices composites: thermal analyses of fibers and composites. Macromolecular Materials and Engineering, v. 291, p. 405-417, 2006.

PANDEY, J.K.; LEE, C.S.; AHN, S.H. Preparation and properties of bio-nanoreinforced composites from biodegradable polymer matrix and cellulose whiskers. Journal of Applied Polymer Science, v. 115, 2493-2501, 2010.

PARISI, F. Advances in lignocellulosics hydrolysis and in the utilization of hydrolysates. Advances in Biochemical Engineering/Biotechnology, v. 38, p. 53-87, 1989.

PASQUINI, D.; PIMENTA, M. T. B.; FERREIRA, L. H.; CURVELO, A. A. S. Sugar cane bagasse pulping using supercritical $\mathrm{CO}_{2}$ associated with co-solvent 1-butanol/water. Journal of Supercritical Fluids v. 34, n. 2, p. 125-131, 2005.

PHISALAPHONG, M.; JATUPAIBOON, N. Biosynthesis and characterization of bacteria cellulose-chitosan film. Carbohydrate Polymers, v. 74, n. 3, p. 482 -488, 2008.

POUGET, J.P.; JÓZEFOWICZ, M.E.; EPSTEIN, J.A.; TANG, X.; MACDIARMID, A.G. X-ray structure of polyaniline. Macromolecules, v. 24, p. 779-789, 1991.

QUINTERO-RAMIREZ, R. Hydrolisys of lignocellulosic biomass. Cuajimalpa, 2008. Division of Natural Sciences and Engineering. Disponivel em:

<http:/ / www.apta.sp.gov.br/cana/anexos/paper_quintero_Brasil.pdf >. Acesso em: 18 jan. 2012 .

RABINOVICH, M.L.; MELNIK, M.S.; BOLOBOBA, A.V. Microbial cellulose [Review]. Applied Biochemistry and Microbiology, v. 38, n. 4, p. 305-321, 2002.

RALPH, J.; LUNDQUIST, K.; BRUNOW, G.; LU, F.; KIM, H.; SCHATZ, P.F.; MARITA, J.M.; HATFIELD, R.D.; RALPH, S.A.; CHRISTENSEN, J.H.; BOERJAN, W. Lignins: Natural polymers from oxidative coupling of 4-hydroxyphenyl-propanoids. Phytochemistry Reviews, v. 3, p. 29-60, 2004.

RAMIRES, E.C.; DUFRESNE, A. A review of cellulose nanocrystals and nanocomposites.

TAPPI Journal, v. 10, n. 4, p. 9-16, 2011. 
RAMIRES, E.C.; MEGIATTO JR., J.D.; GARDRAT, C.; CASTELLAN, A.; FROLLINI, E. Valorization of an industrial organosolv-sugarcane bagasse lignin: characterization and use as a matrix in biobased composites reinforced with sisal fibers. Biotechnology and Bioengineering, $v$. 107, n. 4, p. 612-621, 2010.

RAMOS, L.A.; ASSAF J.M.; EL SEOUD, O.A.; FROLLINI, E. Influence of supra-molecular structure and physico-chemical properties on the dissolution of celluloses in lithium chloride/N,N-dimethylacetamide solvent system. Biomacromolecules, v. 6, p. 26382647, 2005 .

RAMOS, L.A.; MORGADO, D.L.; GESSNER, F.; FROLLINI, E.; EL SEOUD, O.A. A physical organic chemistry approach to dissolution of cellulose: effects of cellulose mercerization on its properties and on the kinetics of its decrystallization. Arkivoc, v. 7, p. 416-425, 2011.

RANBY, B.G. Fibrous macromolecular systems. Cellulose and muscle. The colloidal properties of cellulose micelles. Discussions of the Faraday Society, v. 11, n. 1, p. 158164, 1951.

RATTER, J.A.; RIBEIRO, J.F.; BRIDGEWATER, S. The Brazilian cerrado vegetation and threats to its biodiversity. Annals of Botany, v. 80, p. 223-230, 1997.

REGIANI, A. M.; MARSON, G.; EL SEOUD, O. A.; FROLLINI, E. investigation of cellulose dissolution and acetylation in lithium chloride/N,N-dimethylacetamide system. In: MATTOSO, L. H. C.; FROLLINI, E.; LEÃO, A. [Ed.]. Natural polymers and composites. São Carlos: UNESP-EMBRAPA-USP, 1998. p. 253-239.

RESTOLHO, J.A.; PRATES, A.; DE PINHO, M.N.; AFONSO, M.D. Sugars and lignosulphonates recovery from eucalyptus spent sulphite liquor by membrane processes. Biomass and Bioenergy, v. 33, n. 11, p. 1558-1566, 2009.

RINALDI, R.; SCHÜTH, F. Acid hydrolysis of cellulose as the entry point into biorefinery schemes. ChemSusChem, v. 2, p. 1096-1107, 2009.

ROCHA, G.J.M.; GONÇALVES, A.R.; OLIVEIRA, B.R.; OLIVARES, E.G.; ROSSELL, C.E.V. Steam explosion pretreatment reproduction and alkaline delignification reactions performed on a pilot scale with sugarcane bagasse for bioethanol production. Industrial Crops and Products, v. 35, p. 274-279, 2012.

RODRIGUES, F.A.; GUIRARDELLO, R. Evaluation of a sugarcane bagasse acid hydrolysis technology. Chemical Engineering Technology, v. 31, n. 6, p. 883-892, 2008. 
ROSA, D.S.; GUEDES, C.G.F.; BARDI, M.A.G. Evaluation of thermal, mechanical and morphological properties of PCL/CA and PCL/CA/PE-g-GMA blends. Polymer Testing, v. 26, p. 209-215, 2007.

ROWELL, R.M.; SANADI, A.R.; CAULFIELD, D.F.; JACOBSON, R.E. Utilization of natural fibers in plastic composites: problems and opportunities. In: LEÃO, A.L.; CARVALHO, F.X., FROLLINI, E. Lignocellulosic/Plastic Composites. São Paulo, USP/UNESP, 1997. p. 2351.

RUBIN, E.M. Genomics of cellulosic biofuels. Nature, v. 454, n. 7206, p. 841-845, 2008.

SADDLER, J.N.; HOGAN, C.M.; LOUIS-SEIZE, G.; YU, E.K.C. Factor affecting cellulase production and the efficiency of cellulose hydrolysis. In: MOO-YOUNG, M., HASNAIN, S., LAMPTEY, J. [Ed.]. Biotechnology and Renewable Energy. New York: Elsevier Applied Science, 1986. p. 83-92.

SAEMAN, J. F. Key factors in the hydrolysis of cellulose. In: KLASS, D. L. [Ed.]. Biomass as a nonfossil fuel source. Washington: ACS, 1981. v. 144, p. 185-197.

SAEMAN, J. F. Kinetics of wood saccharification - hydrolysis of cellulose and decomposition of sugars in dilute acid at high temperature. Industrial and Engineering Chemistry, v. 37, n. 1, p. 43-52, 1945.

SAKURAI, K.; MAEGAWA, T.; TAKAHASHI, T. Glass transition temperature of chitosan and miscibility of chitosan/poly[N-vinyl pyrrolidone] blends. Polymer, v. 41, n. 19, p. 7051 7056, 2000.

SAMARANAYAKE, G.; GLASSER, G.W. Cellulose derivatives with low DS: a novel acylation system. Carbohydrate Polymers, v. 22, p.1-7, 1993.

SAMEI, N.; MORTAZAVI, S.M.; RASHID, A.S.; SHEIKHZADAH-NAJAR, S. An investigation on the effects of hot mercerization on cotton fabrics made up of open-end yarns. Journal of Applied Science, v. 8, p. 4204-4209, 2008.

SAMIR, M.A.S.A.; ALLOIN, F., DUFRESNE, A. Review of recent research into cellulosic whiskers, their properties and their application in nanocomposite field.

Biomacromolecules, v. 6, n. 2, p. 612-626, 2005.

SANTOS, M.B.; SANTOS, C.Y.; ALMEIDA, M.A.; SANTOS, C.R.S.; SANT'ANNA, H.L.S.; SANTOS, O.S.N.; SILVA, F.; MARTINS, G.N. Efeito inibitório in vitro de extrato vegetal de Allium sativum sobre Aspergillus niger Tiegh. Revista Brasileira de Plantas Medicinais, [Botucatu], v. 12, n. 1, p. 13-17, 2010. 
SAPUAN, S.M.; LEENIE, A.; HARIMI, M.; BENG, Y.K. Mechanical properties of woven banana fibre reinforced epoxy composites. Materials \& Design, v. 27, p. 689-693, 2006.

SASAKI, M.; KABYEMELA, B.; MALALUAN, R.; HIROSE, S.; TAKEDA, N.; ADSCHIRI, T.; ARAI, K. Cellulose hydrolysis in subcritical and supercritical water. The Journal of Supercritial Fluids, v. 13, p. 261-268, 1998.

SCHAIDLE, J.A.; MOLINE, C.J.; SAVAGE, P.E. Biorefinery sustainability assessment. Environmental Progress \& Sustainable Energy, v. 30, n. 4, p. 743-753, 2011.

SÉBASTIEN, F.; STÉPHANE, G.; COPINET, A.; COMA, V. Novel biodegradable films made from chitosan and poly[lactic acid] with antifungal properties against mycotoxinogen strains. Carbohydrate Polymers, v. 65, n. 2, p. 185-193, 2006.

SHIELDS, S.; BOOPATHY, R. Ethanol production from lignocellulosic biomass of energy cane. International Biodeterioration \& Biodegradation, v. 65, p. 142-146, 2011.

SHIH, C.M.; SHIELD, Y.T.; TWU, Y.K. Preparation and characterization of cellulose/chitosan blend films. Carbohydrate Polymers, v. 78, n. 1, p. 169-174, 2009.

SINDHU, R.; KUTTIRAJA, M.; BINOD, P.; JANU, K.U.; SUKUMARAN, R.K.; PANDEY, A. Dilute acid pretreatment and enzymatic saccharification of sugarcane tops for bioethanol production. Bioresource Technology, v. 102, p. 10915-10921, 2011.

SINDICATO DAS INDÚSTRIAS DE FIBRAS VEGETAIS DA BAHIA [SINDIFIBRAS). Sisal. Disponivel em: <http:/ / www.brazilianfibres.com.br/>. Acesso em: 09 jan. 2012.

SIONKOWSKA, A.; WISNIEWSKI, M.; SKOPINSKA, J.; KENNEDY, C.J.; WESS, T.J. The photochemical stability of collagen-chitosan blends. Journal of Photochemistry and Photobiology A: Chemistry, v. 162, n. 2-3, p. 545-554, 2004.

SIVERS, M.V:; ZACCHI, G. A techno-economical comparison of three processes for the production of ethanol from pine. Bioresource Technology, v. 51, p. 43-52, 1995.

SJÖSTRÖM, E. Wood Chemistry: fundaments and applications. Orlando: Academic Press, 1981. 223 p.

SOUZA, B.W.S.; CERQUEIRA, M.A.; MARTINS, J.T.; CASARIEGO, A.; TEIXEIRA, J.A., VICENTE, A.A. Influence of electric fields on the structure of chitosan edible coatings. Food Hydrocolloids, v. 24, n. 4, p. 330-335, 2010. 
SPIRIDON, L.; POPA, V.I. Hemicelluloses: major sources, properties and applications. In: BELGACEM, M. N.; GANDINI, A. [Ed.]. Monomers, polymers and composites from renewable resource. Amsterdan: Elsevier, 2008. p. 289-304.

SRIUPAYO, J.; SUPAPHOL, P.; BLACKWELL, J.; RUJIRAVANIT, R. Preparation and characterization of $\alpha$-chitin whisker-reinforced chitosan nanocomposite films with or without heat treatment. Carbohydrate Polymers, v. 62, p. 130-136, 2005.

STANA-KLEINSCHEK, K.; STRNAD, S.; RIBITSCH, V. Surface characterization and adsorption abilities of cellulose fibers. Polymer Engineering and Science, v. 39, n. 8, p. 1412-1424, 1999.

STÖCKER, M. Biofuels and biomass-to-liquid fuels in the biorefinery: catalytic conversion of lignocellulosic biomass using porous materials. Angewandte Chemie International Edition, v. 47, n. 48, p. 9200-9211, 2008.

SUGIJAMA, J.; VOONG, R.; CHANZY, H. Electron diffraction study on the two crystalline phases occurring in native cellulose from an algal cell wall. Macromolecules, v. 24, p. 4168-4175, 1991.

SULLIVAN, J.M.; WILLARD, J.W.; WHITE, D.L.; KIM, Y.K. Production of oxalic acid via the nitric acid oxidation of hardwood [red oak] sawdust. Industrial \& Engineering Chemistry Product Research and Development, v. 22, p. 699-709, 1983.

SUN, Y:; CHENG, J. Hydrolysis of lignocellulosic materials for ethanol production: a review. Bioresource Technology, v. 83, p. 1-11, 2002.

SUN, Y.; LIN, L.; DENG, H.; PENG, H; LI, J.; SUN, R.; LIU, S. Hydrolysis of bamboo fiber cellulose in formic acid. Frontiers of Forestry in China, v. 3, n. 4, p. 480-486, 2008.

TAHERZADEH, M.J.; KARIMI, K. Enzyme-based hydrolysis processes for ethanol from lignocellulosic materials: A review. BioResources, v. 2, n. 4, p. 707-738, 2007.

TÁSIC, M.B.; KONSTANTINOVIC, B.V.; LAZIC, M.L.; VELJKOVIC, V.B. The acid hydrolysis of potato tuber mash in bioethanol production. Biochemical Engineering Journal, v. 43, p. 208-211, 2009.

TENGBORG, C.; GALBE, M.; ZACCHI, G. Influence of enzyme loading and physical parameters on the enzymatic hydrolysis of steam-pretreated softwood. Biotechnology Progress, v. 17, n. 1, p. 110-117, 2001.

TIAN, J.; WANG, J.; ZHAO, S.; JIANG, C.; ZHANG, X.; WANG, X. Hydrolysis of cellulose by the heteropoly acid $\mathrm{H}_{3} \mathrm{PW}_{12} \mathrm{O}_{40}$. Cellulose, v. 17, p. 587-594, 2010. 
TOMME, P.; WARREN, R.A.J.; GIKES, N.R. Cellulose hydrolysis by bacteria and fungi. Advances in Microbial Physiology, v. 37, p. 1-81, 1995.

TWU, Y.K.; HUANG, H.I.; CHANG, S.Y.; WANG, S.L. Preparation and sorption activity of chitosan/cellulose blend beads. Carbohydrate Polymers, v. 54, p. 425-430, 2003.

VANDERHART, D.L.; ATALLA, R.H. Studies of microstructure in native celluloses using solid-state C-13 NMR. Macromolecules, v. 17, n. 8, p. 1465-1472, 1984.

WADA, M.; NISHIYAMA, Y.; CHANZY, H.; FORSYTH, T.; LANGAN, P. The structure of celluloses. Powder Diffraction, v. 23, n. 2, p. 92-95, 2008.

WILKIE, K.C.B. The hemicelluloses of grasses and cereals. In: TIPSON, R.S.; DEREK, H. [Ed.]. Advances in Carbohydrate Chemistry and Biochemistry. Old Aberdeen: Academic Press, 1979. v. 36, p. 215-264.

WU, C.S. Preparation, characterization, and biodegrability of renewable resource-based composites from recycled polylactide bioplastic and sisal fibers. Journal of Applied Polymer Science, v. 123, p. 347-455, 2012.

WU, L.; TABUSE, M.; MIYAMOTO, M.; MATSUKI, J.; YOZA, K.; TOKUYASU, K. Sorption of cellooligosaccharides to activated clay in sulfuric acid solution. Biomass and Bioenergy, $v$. 33, n. 5, p. 907-910, 2009.

WU, Y.V.; YU, S.H.; MI, F.L.; WU, C.W.; SHYU, S.S.; PENG, C.K.; CHAO, A.C. Preparation and characterization on mechanical and antibacterial properties of chitsoan/cellulose blends.

Carbohydrate Polymers, v. 57, p. 435-440, 2004.

WYMAN, C.E. Handbook on bioethanol: production and utilization. Washington, DC: Taylor \& Francis, 1996. 424 p.

$X I A N G, Q$. Conversion of lignocellulosic substrate into chemicals: kinetic study of dilute acid hydrolysis and lignin utilization. 2002. $163 \mathrm{f}$. Tese [Doutorado] - Universidade de Auburn, Alabama, 2002.

XIANG, Q.; LEE, Y.Y.; PETTERSSON, P.O.; TORGET, R.W. Heterogeneous aspects of acid hydrolysis of alpha-cellulose. Applied Biochemistry and Biotechnology, v. 105-108, p. 505-514, 2003.

XIANG, Q.; LEE, Y.Y.; TORGET, R.W. Kinetics of glucose decomposition during dilute-acid hydrolysis of lignocellulosic biomass. Applied Biochemistry and Biotechnology, v. 113116, p. 1127-1138, 2004. 
YAMAMOTO, H.; HORII, F. CP/MAS C-13 NMR analysis of the crystal transformation induced for valonia cellulose by annealing at high-temperatures. Macromolecules, v. 26, no. 6, p. 1313-1317, 1993.

YANG, B.; WYMAN, C. Pretreatment: the key to unlocking low-cost cellulosic ethanol. Biofuels, Bioproducts and Biorefining, v. 2, p. 26-40, 2008.

YIN, J.; LUO, K.; CHEN, X.; KHUTORYANSKIY, V.V. Miscibility studies of the blends of chitosan with some cellulose ethers. Carbohydrate Polymers, v. 63, n. 2, p. 238-244, 2006.

ZHANG, Y.H.P.; LYND L.R. Toward an aggregated understanding of enzymatic hydrolysis of cellulose: noncomplexed cellulase systems. Biotechnology and Bioengineering, v. 88 p. 797-824, 2004.

ZHAO, H.; KWAK, J.; WANG, Y.; FRANZ, J.A.; WHITE, J.M.; HOLLADAY, J.E. Effects of crystallinity on dilute acid hydrolysis of cellulose by cellulose ball-milling study. Energy and Fuels, v. 20, p. 807-811, 2006.

ZHU, J.Y.; WANG, G.S.; PAN, W.J.; GLEISNER, R. Specific surface to evaluate the efficiencies of milling and pretreatment of wood for enzymatic saccharification. Chemical Engineering Science, v. 64, p. 474-485, 2009.

ZUGENMAIER, P. Conformation and packing of various crystalline cellulose fibers.

Progress in Polymer Science, v. 26, n. 9, p. 1341-1417, 2001.

ZUGENMAIER, P. Crystalline cellulose and derivatives. New York: Springer, 2008. 285 p. 